Portland State University

PDXScholar

\title{
They sure don't build them like they used to : Federal Housing Administration insured builders' houses in the Pacific Northwest from 1934 to 1954
}

Alfred M. Staehli

Portland State University

Follow this and additional works at: https://pdxscholar.library.pdx.edu/open_access_etds

Part of the Architecture Commons, and the History of Art, Architecture, and Archaeology Commons Let us know how access to this document benefits you.

\section{Recommended Citation}

Staehli, Alfred M., "They sure don't build them like they used to : Federal Housing Administration insured builders' houses in the Pacific Northwest from 1934 to 1954" (1987). Dissertations and Theses. Paper 3799.

https://doi.org/10.15760/etd.5683

This Thesis is brought to you for free and open access. It has been accepted for inclusion in Dissertations and Theses by an authorized administrator of PDXScholar. Please contact us if we can make this document more accessible: pdxscholar@pdx.edu. 
AN ABSTRACT OF THE THESIS OF Alfred M. Staehli for the Master of Arts in History presented 22 May 1987.

Title: They Sure Don't Build Them Like They Used To:

Federal Housing Administration Mortgage Insured Builder's Houses in the Pacific Northwest from 1934 to 1954 .

APPROVED BY MEMBERS OF THE THESIS COMMITTEE:

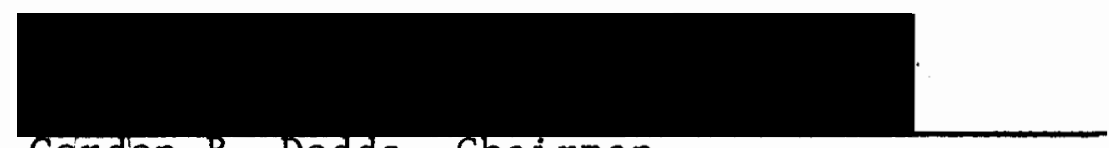

Gordion B. Dodds, Chairman

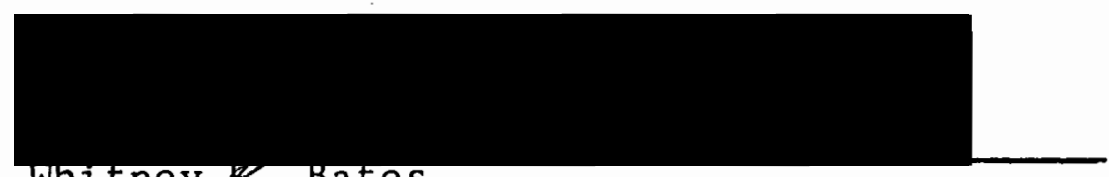

Whitney
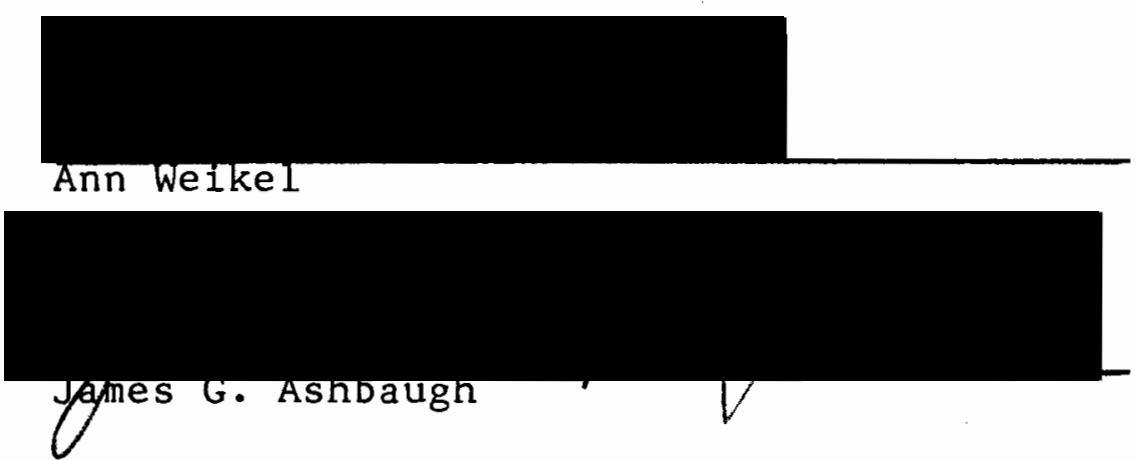

There is a clear change in the architectural qualities of bullder's houses constructed before World War II and in the postwar years. The primary evidence is in the houses themselves and their architectural qualities. This study focuses on the first 20 years of Federal Housing Administra- 
tion insured mortgage builders' houses constructed in the Pacific Northwest region, although expanded with some examples from across the nation to illustrate the general application of the thesis and that this was not a regional phenomenon.

Builders' houses are defined as the common low and middle income houses built speculatively for sale to home buyers and not the custom one-of-a-kind homes.

The reason for the changed pattern in ordinary small houses is shown to be due to a combination of influences: the stimulation of home building and the development of a body of code-like home construction standards under the influence of the Federal Housing Administration; the adoption of innovative building technology developed before World War-II but only first applied on a widespread basis during the war and its subsequent years; and building industry, labor, and market changes resulting from the World War-II mobilization and continuing after it.

There are identifying differences between the prewar and postwar houses, many qualitative differences, and many deficiencies and failures in popular housing in the postwar boom period, but the basic soundness of the houses built and their value was generally the same as the prewar examples despite stylistic changes. Where lower quality is found, it is attributable to the unprecedented number of homes built in a short period after the war and to poor planning. That 
there was maintenance or regulation of quality of building was almost entirely due to the Federal Housing Administration's standards. Without the FHA program and its standards, the home building industry after World War-II would have been totally unprepared to meet the demand for new homes and to maintain an acceptable degree of traditional home building quality control.

The conditions of home building and government housing activities before 1934 are briefly surveyed. The origins of the Federal Housing Administration programs and the hopes for the program are discussed. Popular housing as a part of the American dream is reviewed; and the influences on that dream before, during, and after the war are considered and compared to the results of the postwar home building effort. Popular homes for all was a goal that was never achieved despite unparalleled government efforts and the marshalling of the American home building industry. There is still a housing shortage with no remedy in sight. What is left from the early years of FHA insured mortgage builders' houses is a distinct body of prewar and postwar house architecture which witnesses the revolution brought by a Depression home building stimulation program, home building industry changes, and labor and market changes from the war period. The traditional type of house was discontinued as a builders' house product and was replaced by a more standardized and simplified one. A tradition of labor 
intensive craftsmanship was replaced by mechanization and impersonal crafts work. A measure of popular approval for home designs influenced by the International Modern Style was achieved, not because of understanding and affection for the style, but because the International Modern Style offered ways of reducing building costs. A stripped-down version of the low-cost house combining modern and traditional elements was the result. The low-cost builders' houses of 1945-1954 comprise one more distinctive body of popular residential architecture which has further shaped our cities and reflects the characteristics of the immediate postwar decade. 
THEY SURE DON'T BUILD THEM LIKE THEY USED TO:

FEDERAL HOUSING ADMINISTRATION INSURED

BUILDERS' HOUSES IN THE PACIFIC NORTHWEST

FROM 1934 TO 1954

by

ALFRED M. STAEHLI

A thesis submitted in partial fulfillment of the requirements for the degree of

\author{
MASTER OF ARTS \\ in \\ HISTORY
}

Portland State University 
TO THE OFFICE OF GRADUATE STUDIES AND RESEARCH:

The members of the Committee approve the thesis of Alfred M. Staehli presented 22 May 1987.

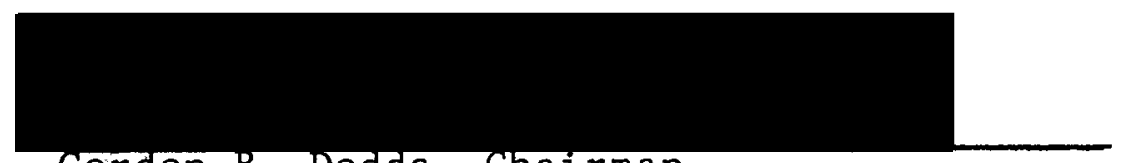

Gordon B. Dodds, Chairman

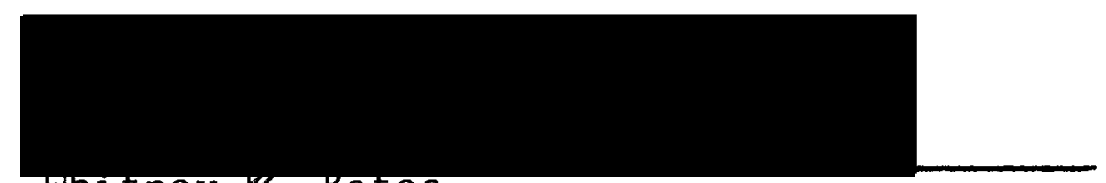

Whitney 2 . Bates

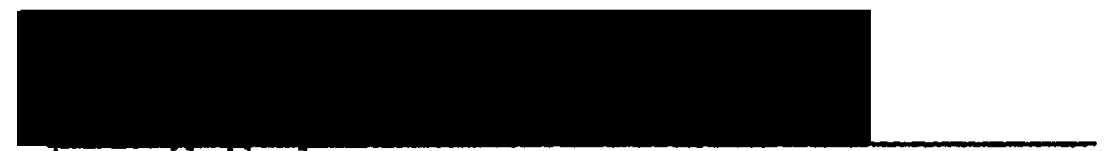

Ann Weikel
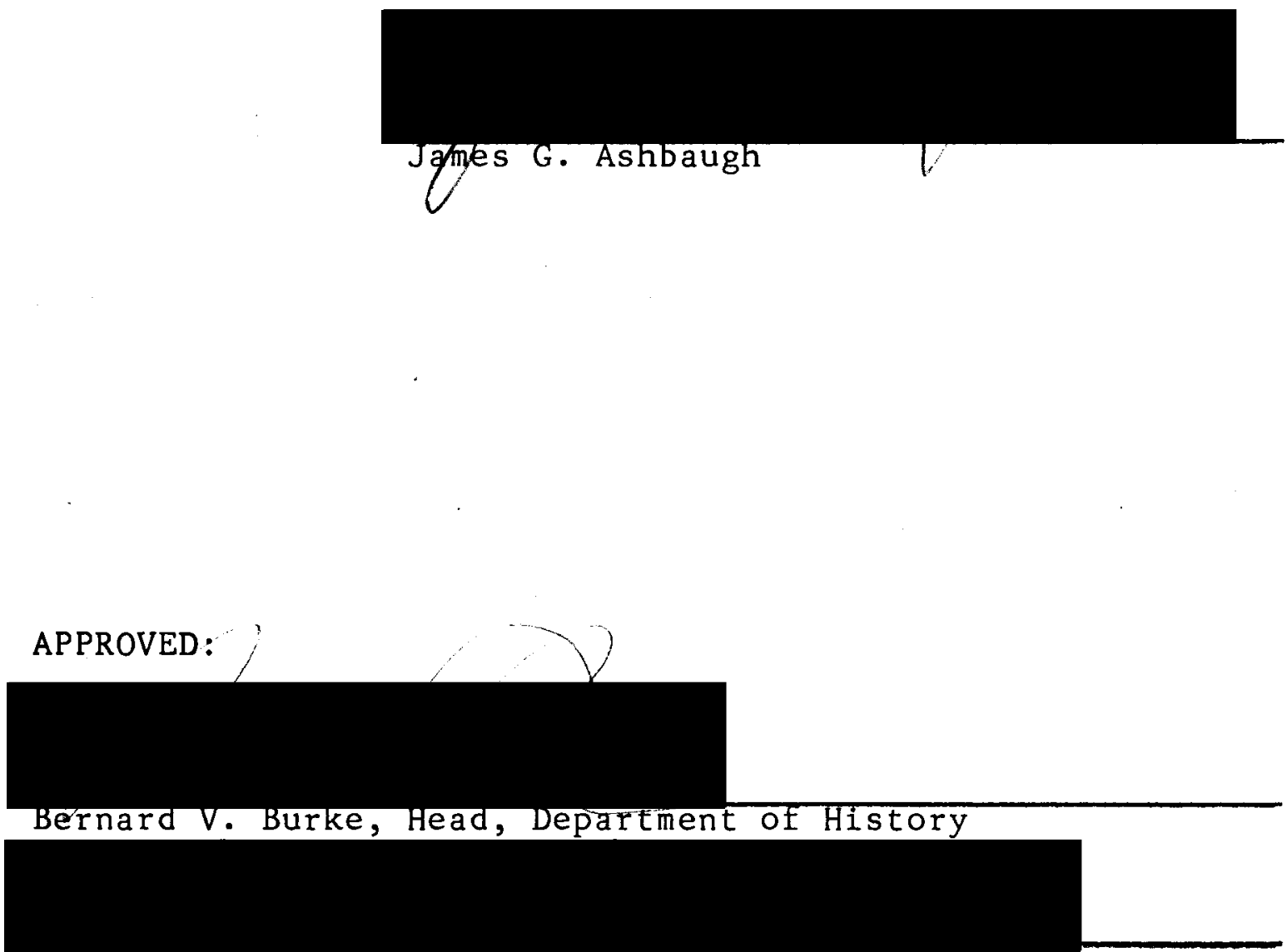
Copyright 1987

Alfred M. Staeh1i 


\section{ACKNOWLEDGMENTS}

In addition to Dr. Gordon Dodds, my thesis advisor, and to the other members of my committee who read the first draft and contributed their editorial corrections, there are others to whom I owe a debt of thanks for their interest in this study and for their cooperation in researching its documentary material.

James Goodrich, Executive Director of the Home Builders Association of Metropolitan Portland, and his assistant, Beverly Schwanke, facilitated my examination of the association's records and library. HBAMP is one of the largest and most active of the associations in the Pacific Northwest and is fortunate to have retained a substantial collection of its early records.

Donnie Crespo, Archivist for The Weyerhaeuser Company, Tacoma, assisted my research into lumber industry developments in home building in my 20 year study period by leading me into their record keeping system and guiding my research in those documents. I was limited in the amount of time I could spend in the Weyerhaeuser Archives, and with her help it was a very productive day.

The staff members of the National Archives and Library of Congress, Washington, are among the most dedicated public 
servants I have met. Each person I contacted on two visits to Washington was especially helpful and supportive, guiding me to indexes and parallel resources that I might not have thought to check. The volume of material that is available is truly amazing, and it is remarkable that anyone would repeatedly keep bringing out and returning more and more of it on the chance of my finding just the right document.

Lastly, there are al1 the home owners whose peace I disturbed in order to photograph their homes and neighborhoods. Those who caught me and demanded to know why their house was being photographed were surprised to learn that there was anything special about their home. They had not known about the 1938 report by the Federal Housing Administration or about the featuring of their homes in postwar home shows and newspaper promotions. Because of their cooperation, I obtained much additional information about similar houses in their neighborhoods so as to widen the selection of house examples for comparison. 
TABLE OF CONTENTS

PAGE

ACKNOWLEDGEMENTS

LIST OF FIGURES

ix

\section{CHAPTER}

I INTRODUCTION . . . . . . . . . . . . . . . . 1

I I BUILDERS' HOUSES BEFORE 1934 . . . . . . . . . 5

Financing Homes . . . . . . . . . . . . . 8

Home Building . . . . . . . . . . . . 12

Home Styles and Architects . . . . . . . 17

The International Modern Style

\& Small Homes... . . . . . . . . . 20

New Towns and Smal1 Homes . . . . . . 23

Building Industry Developments . . . . 25

Government Housing Programs . . . . . . . 34

The Home Building Boom in the Twenties . 36

II A NEW DEAL FOR BUILDERS' HOUSES:

THE FEDERAL HOUSING ADMINISTRATION . . . . .

New Deal: The National Housing Act of 1934 \& FHA . . . . . . . . . . . .

FHA in Oregon and the Pacific Northwest. 48

FHA Results in the Depression Years. . . 53 
IV THE AMERICAN DREAM HOME IN

THE GREAT DEPRESSION . . . . . . . . . . . 56

The Architecture of Homes and New Towns.. 59

Housing Research is Supported. . . . . 65

Industrialized Housing Solutions . . . . 69

Popular Culture and

the American Dream of Home . . . . . . . 76

The Lumber Industry

and the Low-Cost Home . . . . . . . . . .

Government's Influence on

the Dream of Low-Cost Homes... . . . .

Housing Industry Organization at

Depression's End . . . . . . . . . . 95

V FHA INSURED DEPRESSION HOUSES . . . . . . 100

The Modern Style Thirties'

Builders' House . . . . . . . . . . . 107

Other Examples of Depression Homes . . . 110

Architects and Depression Houses . . . . 112

VI WARTIME HOUSING INFLUENCES . . . . . . . . . 118

Technology Carry-0ver into Postwar

Home Building... . . . . . . . . 135

VII POSTWAR HOMES DEMAND AND

THE HOME BUILDING INDUSTRY . . . . . . . . . 138

Some Progress in Meeting

the Housing Need . . . . . . . . . . . 146

Industry Changes in

Postwar Builders' Houses . . . . . . 149

Home Building Labor . . . . . . . . . 151 
The Rise of the Merchant Builders . . . 153

New Home Building Systems and Products. 163

VIII THE POSTWAR LOW-COST DREAM HOUSE . . . . . 171

Design Changes . . . . . . . . . . . 182

Modern Architectural Influences

on the Small Home... . . . . . . . . . 185

Sma11 Low-Cost House Plan Typology . . . 191

Lost Architectural Elements . . . . . . 196

The Typical Small Postwar House. . . . 200

IX CONCLUSION: CHANGES IN BUILDERS' HOUSES

OVER 20 YEARS . . . . . . . . . . . . . . . 205

FHA Standards Changed

the Home Building Codes . . . . . . . 205

How Went the Dream? . . . . . . . . 208

The Home Building Industry's Mark. . . . 217

They Aren't Building Them

Like They Used To... . . . . . . . 223

A New Balance Between 01d and New Houses. 227

The Lost Arts Are Not Lost . . . . . . 231

LIST OF WORKS CONSULTED . . . . . . . . . . 233 
A11 photographs and photo-copies are by the author unless another source is given.

1. A Featured 1938 FHA Model Home . . . . . xv

2. A postwar GI "dream house" built on a Portland infill lot as part of a group but not a subdivision . . . . . . . .

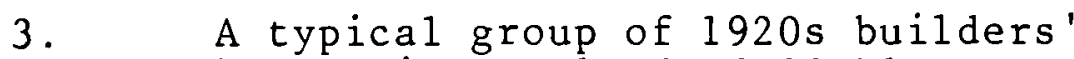
houses in Portland, 6000 block N. Michigan Ave. . . . . . . . . . . . . .

4. Drawing for a Colonial Revival cottage from the House Beautiful Annual-1925 . . 13

5. Drawing of balloon framing . . . . . . 15

6. Frank Lloyd Wright designed pre-cut house for American Homes, Milwaukee, Wisc. . . . . . . . . . . . . . . . .

7. Illustration from American Year Book: Modern Homes, Their Design and Construction, "What is This Modern Trend?". .

8. Early prefabricated example from Home Owner's Year Book, Aust in C. Lescarboura (N.Y: Sci. American Publ., Co., 1924)

9. Examples of Portland prefabricated house models . . . . . . . . . . . . 28

10. Photograph plate from White Pine Series.

11. Typical detail from a measured drawing in White Pine Series . . . . . . . . .

12. Puget Sound Navy Yard, Bremerton, Washington 
13. Plan of Bremerton Housing . . . . . . 36

14. A well designed, compact, 1933 house plan from the WCLA booklet . . . . . . .

15. A FHA eligible house design by architect Margaret Fritsch is featured in a 1938

Sunday Oregonian story

16 House for Harry $C$. Weller, architect, Pullman, Washington..........

17. A 1936 Forum house by George Wellingon Stoddard, architect, Seattle. . . .

18. Bybee-Howel1 House, Sauvie Island, Oregon

19. The Weyerhaeuser "Lumber House" displayed at the Chicago Exposition

20. Usonian Pope-Leighey House, Woodlawn, Virginia

21. Frank Lloyd Wright designed Usonian house at Woodlawn

Fenner pre-cut homes

24. Advertisement for a modular panel building material

26. Houses of Tomorrow, Chicago Exposition, 1933-34.............. . .

27. Official views of the New York Worlds Fair, 1939 . . . . . . . . . . . . . .

28. The Hardy Family in its traditionally

styled dining room . . . . . . .
29. Traditional style TVA house, Norris, 
31. Recent views of Greenbelt, Maryland.

32. Longview Homesteads homes, 1939 . . . .

33. Longview Homesteads' site map

36. View of FSA migrant labor camp housing, Yakima, Washington, 1941

37. Defense housing trailer building in Los Angeles, 1942

41. Dr. Carl W. Emmons Residence, Salem, Oregon

42. FHA homes development, Belmont Park, N.Y., 1939

43. A Modern Colonial Revival Style house.

47. A Burt Smith builders' house designed by John Yeon in 1939

48. Use of fixed window lite and separate ventilation panel in defense housing, Vanport, Portland, 1942 . . . . . .

49. FSA trailer camp for defense workers near San Diego, California... . . . . 
51. Site map and recent photographs of Westpark, Bremerton, Washington... . 124

52. View of the Yesler Terrace project, Seattle, Washington... . . . . .

53. Details of Yesler Terrace project, entrance pylons and private yards... .

54. McLoughlin Heights, Vancouver, Washington

55. Defense housing in Portland and Vancouver

56. McLoughlin Heights Community Center buildings.

57. Farm Security Administration wartime housing project, Taft, California, 1942 .

58. Columbia Villa, Portland, Oregon

59. Royal Barry Will

60 . GI Homes all in a row

61. Asbahr Homes' development in SE Portland

62. Promotion for the 1953 Home Show held in the old Ice Arena in Northwest Portland

63. Lindberg Homes development, South Eugene, c.1948 ......

64. Kaiser's Panorama City, Los Angeles, California

65. Advertising brochure illustrations for the General Panel Homes . . . . . . . . The Rudy Wolf House, Hollywood, 1947 . . Plan for an Eichler Home Levittown, Pennsylvania 
70. Examples of home building planning by the Small Homes Council...... . 167

71. Little boxes all in a Row, Daly City, California

72. Marlene Village, Beaverton, Oregon . .

73. Newspaper advertisement for Marlene Village................ . 176

74. A Marlene Village house, 1986. . . . . 178

75. Marlene Village home . . . . . . . .

76. Postwar Colonial Revivival Style house and plan ............... 183

77. A Sunset Western Ranch Home . . . . . . 185

78. Modern home designs by Van Evera Bailey and Paul Kirk........ . . 187

79. A typical modern open style house plan . 189

80. Sma11 Homes Council Demonstration House.

81. Varieties of typical small house plans.

82. Changed eave details and finishing which characterize the prewar and postwar houses.

83. Typical storage wall type cabinet details for builders' houses . . . . .

85. One of the larger homes typical of 1954 . . . . . . . . . . . . . . . . 203

86. Selected postwar builders' house examples in Portland . . . . . . . . 210

87. Selected builders' house house examples in Portland 
88. An FHA minimum size, 888 square foot three bedroom house, with bath, kitchendining area, utility room and living room

89. Advertisement for home loans, 1951 . .

90. A montage of 1951 model homes, Nationa 1 Home Week examples..... .

91. 1954 model homes . . . . . . . . . . 216

92. The Souweine Residence, Amherst, Massachusetts, 1985 . . . . . . . . . 218

93. A typical postwar builders' house with a rectangular plan, straight modern ines, but with an attempt at "carpenter's" ornamentation on the garage door. . . . . . . . . . .

94. A 1951 Colonial Revival Style builders' house . . . . . . . . . . . . . .

95. A modern picture window house......

96. Special pattern siding was featured on the early postwar houses........

97 . A 1938 FHA house in Portland . . . . . . 


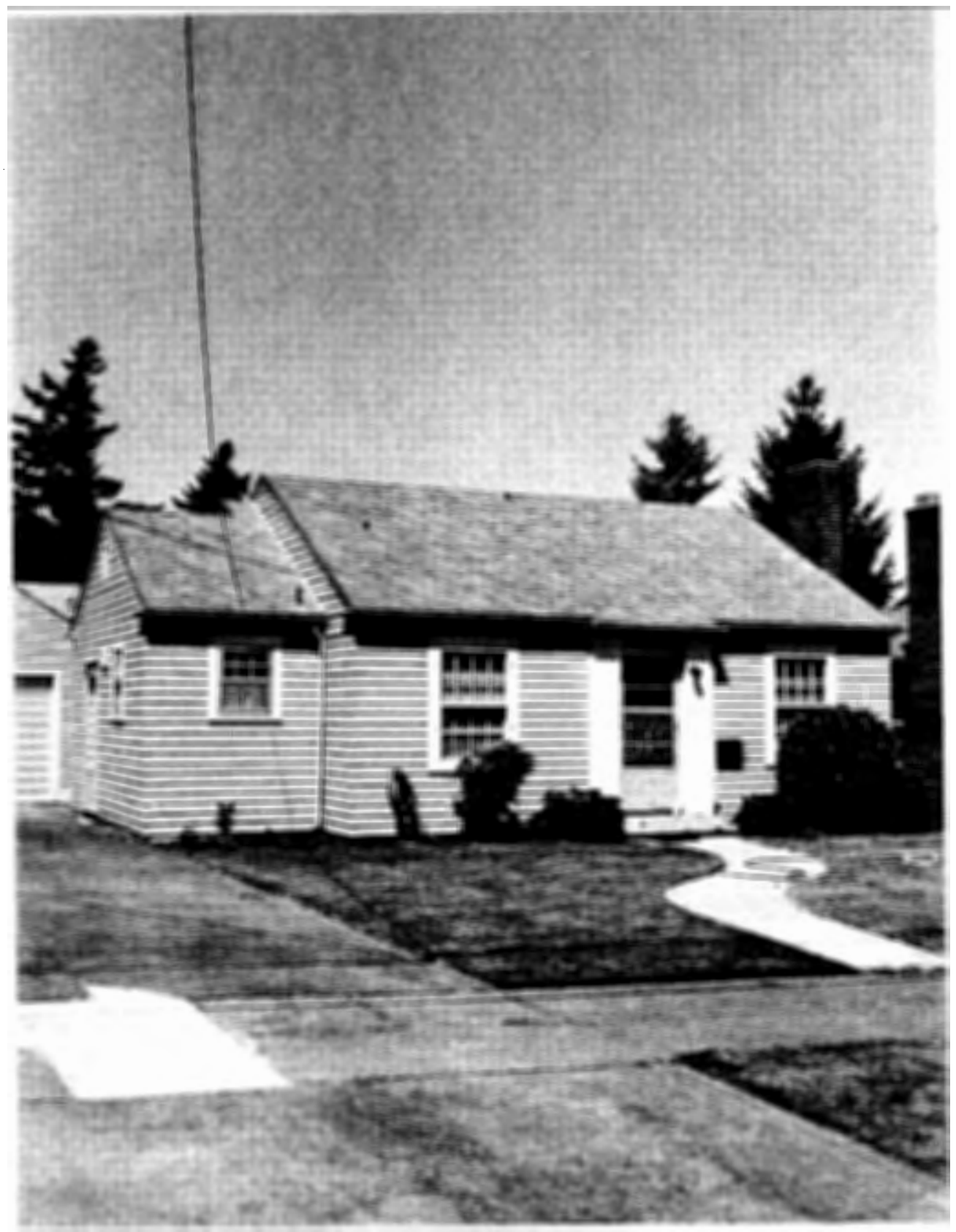

Figure 1. A featured 1938 FHA model home. Clarence Miller residence, 4211 NE 63rd Avenue, Portland. An exemplary Colonial Revival Style builders' house. 


\section{INTRODUCTION}

Definition: A Builders' House is a popular lower or middle income home built speculatively for sale to the home buyer. The house may be architect designed but not for custom building. It is typically reproduced many times from a single stock design, sometimes with variations made by the home builder. An individual home purchaser may commission a builders' house based on a stock plan or even order some custom alterations, but the house remains a builders' house and is not a custom home design.

In 1980 and 1981, while conducting the visual survey work of identifying potential historic landmark buildings for the City of Portland's Historic Resource Inventory, 1 I observed that there is a clear distinction in the qualities of builders' houses built in the Depression decade before World War-II and those of houses built in the decade following the war. The changes in styles, detailing, and to some extent construction methods and materials are so pronounced that the question arose as to why this occurred. As I looked at more and more houses throughout Portland's neighborhoods, it seemed that there were several factors underlying the effects. The eligibility limits and conditions set by The Federal Housing Administration (FHA) were a

${ }^{1}$ Historic Resource Inventory, City of Portland, Oregon (Portland: Bureau of Planning, City of Portland, 1984). 
major influence. FHA minimum standard requirements for construction had resulted in more uniformity in home designs, in building code requirements, and home building practices whether or not the particular house was built. and sold under an FHA insured mortgage. Also, there had been building technology innovations, new tastes, new materials, and labor and economic changes adopted during World War-II and in the years following it which made the prewar builders' house uneconomical, a discontinued home type.

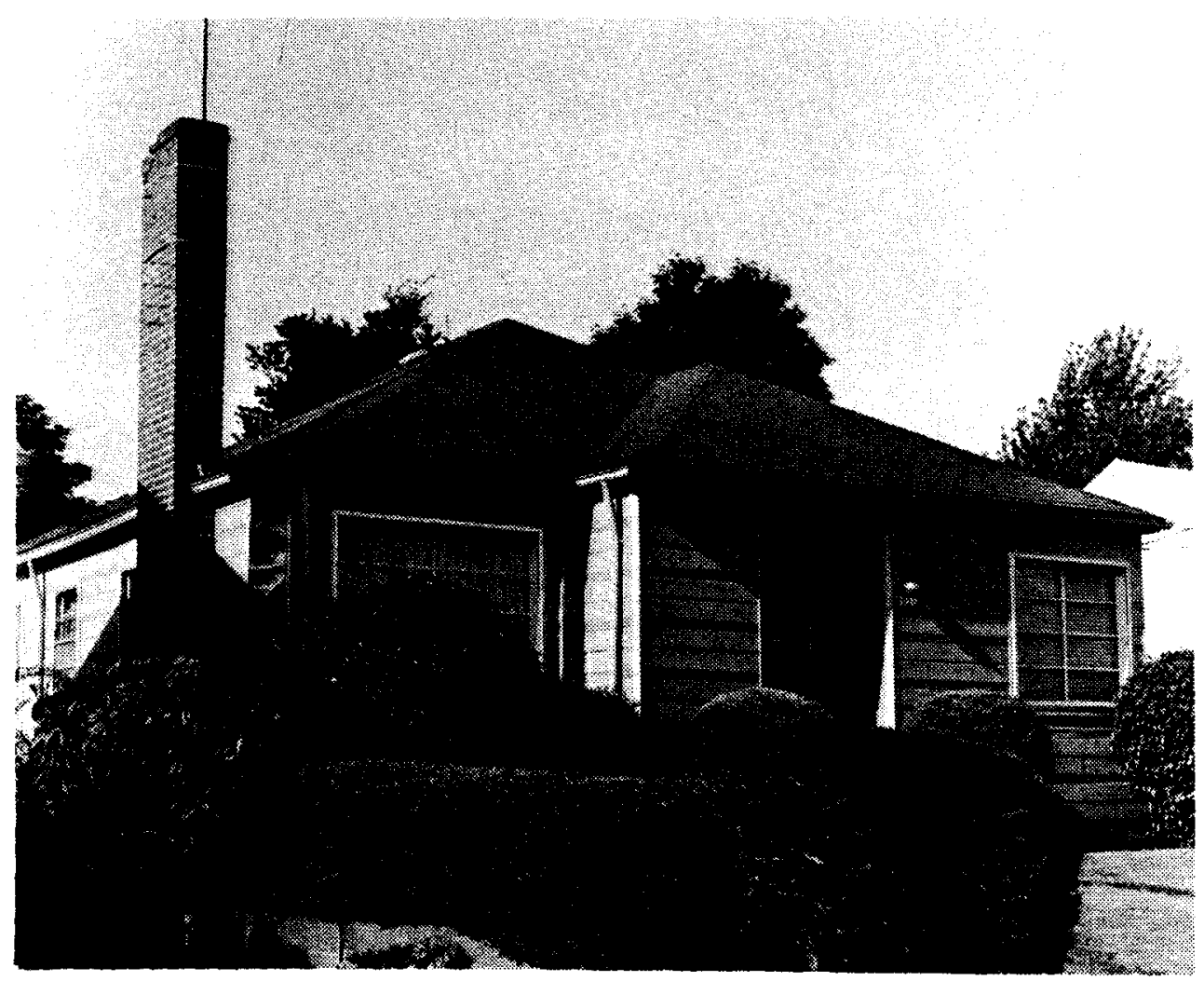

Figure 2. A postwar GI "dream house" built on a Portland infill lot as part of a group but not a subdivision. SE 80 th and Market streets. Note the special pattern siding which is characteristic (discontinued c.1960). 
This study, then, is a typological comparison of selected typical builders' houses built under FHA insured mortgage requirements and related programs between 1934 and 1954. The prewar houses which are selected are those described in a 1938 report to the FHA Director and used in an exhibit of the program's accomplishments. 2 Information on 29 houses in Portland, other Pacific Northwest cities, and a few other United States cities in southwest and eastern states was collected. The Oregon homes were looked at in more detail to see their present condition and were photographed. A few other prewar housing projects are included because they relate to the overall development of government supported builders' houses. Postwar houses which are studied are those featured in "Home-of-the-Week," National Homes Week, Home Show, and similar home building and marketing promotions in the Portland area. To supplement the promotional houses, they are related to the activities of $10 c a 1$ architects and builders and to national influences on low-cost home design. The historical background of low-cost home building before 1934 is briefly included because it determined the initial FHA program direction and the type of small houses built as the program was being implemented.

2FHA Sample Folders of Typical American Homes (19341938), FHA Sample Case Files for Homes, selected cities. National Archives, Washington, D.C. 
Despite occasional home builders' mistakes and a popular observation that the new houses were jerry-built, it is my conclusion that the postwar houses generally are as soundly built and represent as good value for their cost as their prewar counterparts. The effect of FHA insured mortgage program's construction standards was to strengthen and make more uniform the building code standards for homes, producing an overall higher quality of house for the buyer at less risk of defects. Any real and perceived deficiencies in the postwar houses are attributable to the elimination of certain home features (such as basements) to keep costs low, to changes in design and details which look poorer if maintenance is neglected, and to the much higher volume of building which often concentrated low-cost houses in new subdivisions instead of dispersing them among older and larger homes in established neighborhoods. However, in adopting the minimum FHA building standards, the building industry tended to build down to just meet the minimum requirements in order to further keep costs low and productivity and profits higher. There was a loss of home building pride and craftsmanship and of stylistic integrity which did diminish the housing product. 


\section{CHAPTER II}

\section{BUILDERS' HOUSES BEFORE 1934}

Toward the general housing problem the architectural profession has been spurred into activity by reason of the war (WW-I), and to its credit be it said, it is now thoroughiy aroused. 3

Home ownership has been a part of the American Dream from the beginning. The promise of free or $10 w-c o s t ~ 1$ and ownership in America and the opportunity to build or buy a home for the family on that land attracted immigrants who could otherwise never achieve that goal in their native countries. The artisan and yeoman who owned his home and land was central to Thomas Jefferson's concept of how the United States and its government should develop. In a new land which appeared to have unlimited frontiers, there seemed to always be land available at low-cost that provided at least the minimum basic materials from which a house could be built for just the investment of one's labor and skills. The ideal of 1 and and home ownership came with the colonists, immigrants, and pioneers and was fixed, as it had been from wherever they came, as the symbol of achievement and solid family values. The home and its land frequently

${ }^{3} \mathrm{Cl}$ aud Bragdon, FAIA, Architecture and Democracy (N.Y: Alfred A. Knopf, 1918), p. 33 . 
represented the largest part of a family's estate.

Home building has always been a mixed industry of professional builders, the early carpenters and masons, combined with a smaller number of owner built homes. By the twentieth century, professional builders built both homes on commission and homes on speculation. Architect designed custom and stock home plans were used as well as many kinds of other stock published plans; however, architects generally practiced as gentlemen among gentlemen and did not design smaller homes for low and lower middle income families. Many builders were skilled in planning and building homes and did not necessarily employ an architect.

The home building industry was one of the most typical of unregulated entrepreneurial systems. Home building standards, as distinct from commercial building standards, were slow in coming under regulation by building codes. The Portland Housing Association fought for a housing code in 1918 with support from the City Club, but was opposed by real estate interests, contractors, and architects. The Portland housing code was adopted in 1919 and was largely a self-regulating one. 4 Those early codes were primarily based on the National Board of Fire Underwriters' National Board Building Code which was limited to fire resistance,

${ }^{4}$ Charles S. Rosenbaum, Housing and Housing Reform in Portland, Oregon, 1900-1934: An Examination of the Response to Urbanization During the Progressive Era, thesis, Reed College, Portland, 1972, pp. 4, 22, 52. 
exit, and fire fighting or protection requirements; no standards for other construction, habitation, or sanitary concerns. Whatever the builder built, the home buyer necessarily accepted. When there was a choice of builders and neighborhoods, the prospective home buyer might choose based on apparent quality differences or the builder's reputation.

The typical home builder bought one or more lots in an established subdivision within city boundaries and built his houses from stock plans. If the builder was inclined to innovation or influenced by home style fashions, he might make cosmetic variations in the porches, attic dormers, roof slopes, and trim to make adjacent houses appear different; but more often, one builder's houses within a block or single street were almost identical. Builders built no more than several houses in a year, often only two or three. They were limited by the amount of capital they could raise and afford to tie up in unsold homes and lots. They performed much of the building work themselves, employing similarly self-employed specialty contractors to do the work they could not do with their own small crews. Payrolls were small, with few employees and low wages. When one house was sold, the builder could begin another---if he had made a profit. 
F INANCING HOMES

Home financing for the buyer was a major undertaking which often ended in foreclosure and loss of the house to the mortgage holder. The stereotypical vaudevillian crisis of mortgage foreclosure, or celebration when it was paid off, was real. While the amounts of the mortgage loans were small by today's costs, they represented heavy obligations for the average family. A customary feature of earlier homes was the ornamental button inlaid in the stairway newel post signifying that the house was owned free and clear.

"Repayment Like Rent" was a commonly stated inducement for the prospective home buyer to finance a house. An advertisement for the Puget Sound Savings \& Loan Association, Seattle, 1915, offered what were typical mortgage terms: two to ten year term mortgages at from $5.38 \%$ to $5.85 \%$ interest as the term lengthens. For a $\$ 1,000.00$ loan, the monthly payments ranged from $\$ 46.15$ for a 24 month term to $\$ 13.21$ for a 120 month term. Prepayment was permitted.5 Another source describes two alternate mortgage types, the straight mortgage and the "installment loan plan" or amortizing mortgage. Savings banks would generally loan up to $60 \%$ of the value of the building and land with closing costs of $1 \%$ additional. Sometimes $70 \%$ loans were available.

\section{$5 \mathrm{Mr}$. and Mrs. W. W.DeLong, Seattle Home Builder and} Home Keeper (Seattle: Commercial Publishing Co., 1915), p. 18. 
Mortgage bankers charged $1 \%$ to $2 \%$ commission for their loans. Building and loan associations would loan up to $70 \%$ with $1 \%$ of the face mortgage value paid per month at about $6 \%$ interest, making monthly payments of $\$ 60.00$ on a $\$ 6,000.00$ house with a 11-12 year mortgage. Second (junior) mortgages, commonly necessary to obtain cash for other purposes or investments, bore interest rates of up to $15 \%$ and carried severe foreclosure provisions. 6

With a straight mortgage, interest is payable either quarterly or semi-annually throughout the loan term; when at the end, the whole principal is due. In an amortizing loan, a monthly payment is applied both to a declining sum for interest and an increasing sum to principal, until the end of the term when the mortgage is paid, zero balance, "It is an easy method of getting out of debt."7 Substantial down payments were customary, about $25 \%$ of the principal amount or value of the land, building, and improvements. In addition, there were the usual costs for taxes and insurance. A comparable obligation at 1987 prices would be a $\$ 25,000.00$ down payment plus closing costs and a $\$ 75,000.00$ mortgage at $6 \%$ interest for ten years with monthly payments of approximately $\$ 780.00$ plus taxes and insurance.

${ }^{6}$ Charles G.Loring, ed., The House Beautiful Annual, 1925 (Boston: The Atlantic Monthly Co., 1924), pp. 13-18.

70. M. Akers, The Telegram Plan Book (Portland: Telegram Publishing Co., 1924), p. 20. 
Second mortgages on the home were customary and added to the monthly payment and pay-up burden. Very few families could afford to have such a large portion of their assets invested in their home. As the family fortunes rose and fell along with the cycles of national economic health or their particular circumstances, it was necessary to borrow on the equity in the home to pay for other necessary expenses or to support the family during lean times. Such was the psychological onus of being a house renter (apartments were generally unheard of in most communities) that the risks of trying to buy a house were accepted as being a normal part of achieving the home ownership goal.8 The old abstracts of title, given when property changed hands, recorded the many times that the equity in a family home was used as collateral for short term loans to pay for business ventures, medical expenses, and other needs.

The problems of home ownership and its financing were recognized and studied beginning in the late nineteenth century. The qualities of a good house, its management and housekeeping, were addressed by a succession of theorists

${ }^{8}$ Gwendolyn Wright, Building the Dream: A Social History of Housing in America (N.Y: Pantheon Books, 1981), Edith Louise Allen, American Housing (Peoria: Manual Arts Press, 1930). Discussions on home ownership ethic and building conditions. 
and reformers and by the new home economics profession. 9 Except for a few notable examples of slum and tenement clearance projects, there was little government intervention in home building. It was believed to be a strictly private concern most appropriately left to free enterprise and the markets.

Out of the need to provide for home buying and to afford some protection to the purchasers, mutual savings banks and building and loan associations were organized in 1815 as an alternative means for individuals to save money at a better interest rate, to borrow that money on more favorable terms, or invest it in a home with less risk of foreclosure than the terms at commercial banks. The United States Savings and Loan League was founded in 1893. The mutuals and building associations were frequently associated with ethnic and fraternal organizations and were cooperatives in the sense that the investors were the owners; any profits from their operations were returned to the depositor-owners in the form of higher interest rates on the savings. There was a decline in the popularity and formation of these "peoples' banks" after the Civil War, but they

9See: Godey's Magazine; Catharine E. Beecher and Harriet Beecher Stowe, The American Woman's Home, reprint of 1869 edit. (Hartford: Stowe-Day Foundation, 1975); Calvert Vaux, Villas and Cottages (N.Y: Harper \& Brothers, 1857); 0 . S. Fowler, A Home for Al1, or The Gravel Wall and Octagon Mode of Building (N.Y: Fowler \& Wells, 1854); and, Linda Ray Balderston, Housewifery (Philadelphia: J. B. Lippincott Co., 1924). 
continue to exist today. 10

HOME BUILDING

The private home built in the 1920 s and 1930-33 was predominantly in one of the popular revival styles, Classic Greek or Roman, Tudor, French Chateau, Italian Villa, Spanish, and American Colonial. Perhaps, the American Colonial Revival Style, or Cape Cod, was preferred by more builders than any other style as it was more adaptable to small homes and used more of the most available materials and building skills than the other styles required. There was a certain belief that the Colonial Revival style was the one style most appropriate to this country and its history.

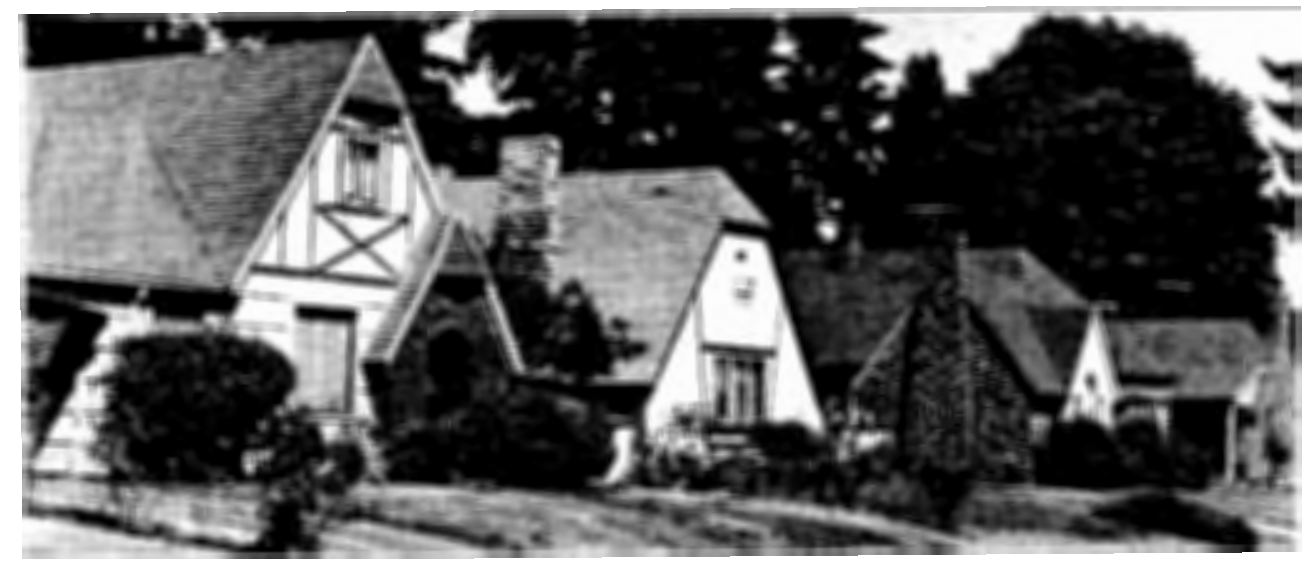

Figure 3. A typical group of 1920s builders' houses in Portland, 6000 block N. Michigan Ave.

$10 \mathrm{Alfred} M$. Staehli, interview at bank. History of Oregon Mutual Savings Bank, now Oregon First Bank, Portland, 30 May 1985. Established in 1930 under Oregon State Law as a mutual savings bank, it was unique among Oregon Banks until forced to reorganize in the 1980 s. 


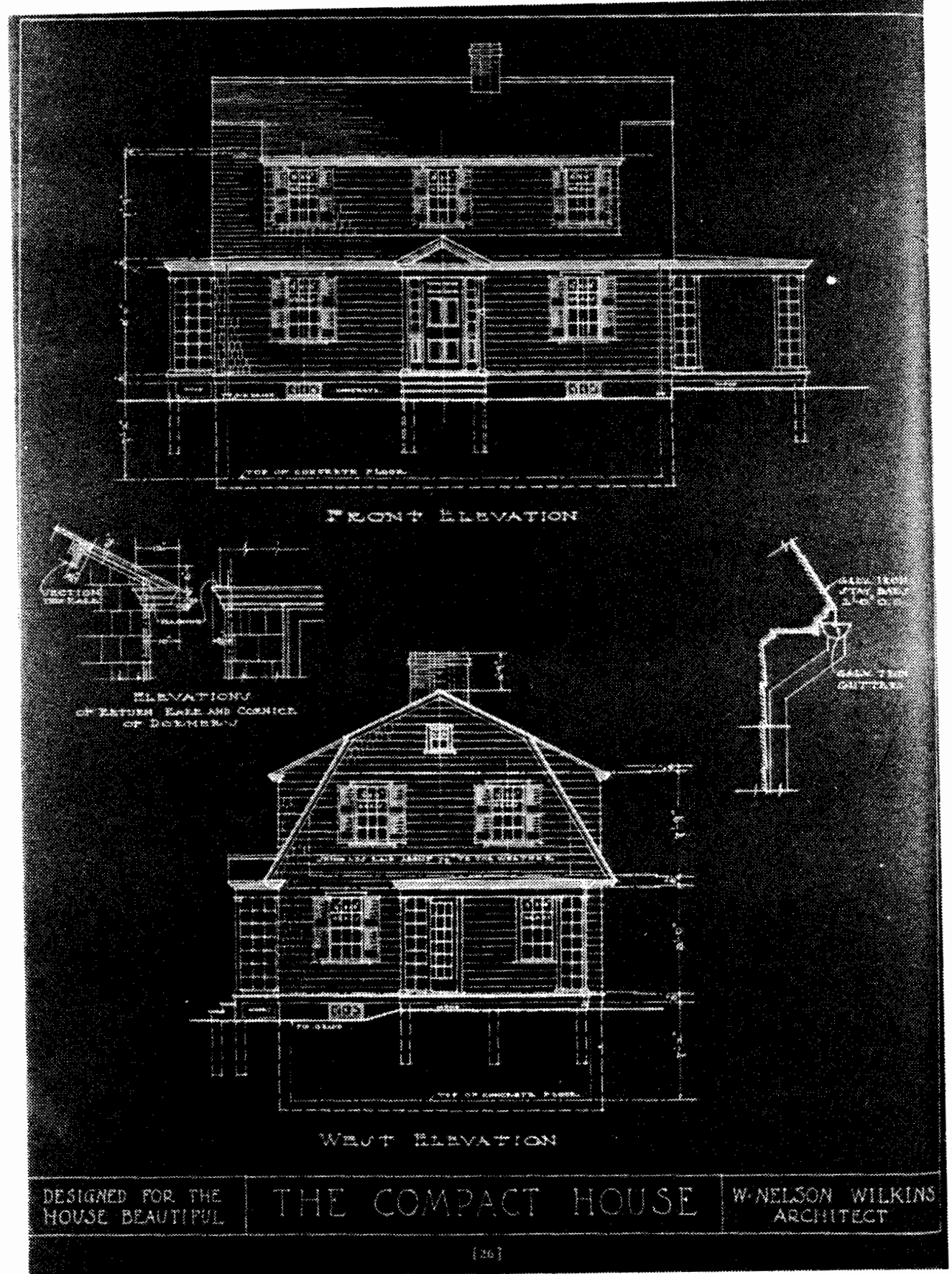

Figure 4. Drawing for a Colonial Revival cottage from the House Beautiful Annual-1925.

Building is one of the most tradition bound technologies; the customary methods and materials persist long after new ones are developed largely due to the individuali- 
stic nature of building. A skilled builder who has taken pride in his work does not change his methods and preferred materials just because he learns about alternatives. Let the others take the risk of changing, "I know how to build a house right." Thus nearly all of the normal home building practices which are currently employed today were known and illustrated in the $1910 \mathrm{~s}$ and 1.920 s but were not as widely used then as now.

The manner of designing the wood frame for the typical small home is based on fundamental building technology. By the later nineteenth century, heavy timber framing had disappeared, replaced by several methods of building with mill sawn lumber and boards of more or less uniform dimensions. In place of heavy timber framing which can be traced back to medieval Europe, home builders preferred balloon framing which is generally accepted as having been invented in Chicago in 1833 and which spread to wherever plentiful mill sawn lumber and boards and inexpensive machine made nails could be had. Several other light wood framing methods were also used to a 1 imited extent, drop girt and box construction among them, but these are not important to a discussion of builders' houses. The one other alternative method of light wood framing for houses, western framing or western platform frame, is frequently shown along with the 
others but was not commonly adopted until the 1930s.11

Balloon framing is dependent on the availability of very long sawn studs (the vertical members which reach from

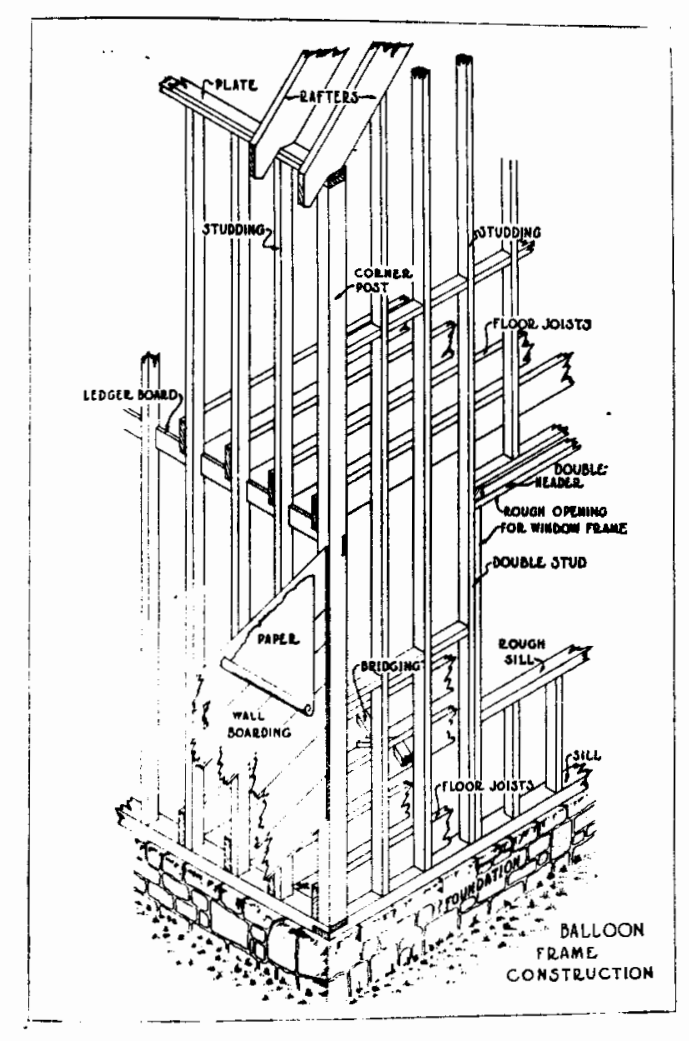

Figure 5. Drawing of balloon framing.

foundation to roof level in one piece). 24 foot long studs are commonly required for a two story house. A balloon framed wall is a flimsy thing until it is braced with the upper floor and attic/roof framing. Sometimes built flat and erected by a team of men with poles, it may also be built by erecting one stud at a time along with related

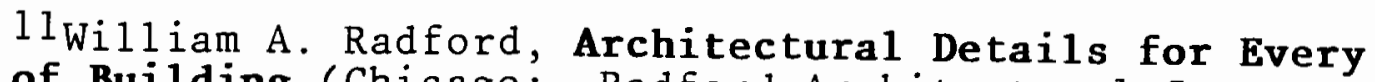
Type of Building (Chicago: $1925)$, PP. 13-15.

Radford Architectural Company, 
framing until the shell is partially complete---appearing like a candle spiked cake until the roof is framed. Balloon framing has other problems associated with it which caused its use to be discontinued after several generations: poor fire resistance, unequal shrinkage problems, labor intensivity, and the requirement for very long sawn members.

Nearly all other normal building practices for both wood framed and masonry houses may be found used today except where there has been a change in the materials used in the building system. Plywood or other panels have replaced the former sawn "one-by..." board sheathing and there are many new styles and materials for siding. Gypsum board has largely replaced 1 ath and plaster, and the exterior envelope of the building frame is insulated to control heat loss or gain; but foundation building, roofing, flooring, masonry veneers and walls, cabinetry, and traditional finishes have changed very little in eighty years. Housing industry labor before 1934 was effectively organized only to a very limited extent. A major problem for the unions then as now was the open shop and the lack of popular support for organized labor. The training of building trades workers was a combination of on-the-job experience, trade school programs (of which Portland's Benson High School was a leader), and some limited union 
apprenticeship programs.12 Among the building trades, carpenters were the most powerful craft union in the nation by 1920.13 Despite the collection of many building trades into industry wide organizations (Portland Building Trades Council), home building labor was comprised of largely unorganized craftsmen, smal1 independent builders, piece work tradesmen, and independent subcontractors.14 The building trades were given a push toward union organization by the National Recovery Administration (NRA) "We Do Our Part" programs in the early New Deal years and by the government sponsored building programs like the Tennessee Valley Authority and slum clearance projects; however, "big labor" did not include the house builders. 15

HOME STYLES AND ARCHITECTS

Plans and styles of pre 1934 builders' houses were determined by a variety of influences: a limited amount of architectural leadership, a continuing tradition of home plan and style books, and an emerging influence of the home building materials industry. Architects continued to design

\section{Craig E. Wollner, The City Builders: One Hundred} Years of Union Carpentry in Portland, Oregon, 1883-1983 (Portland: Carpenters Union Local \#247, 1984), pp. 56-57.

13 op. cit., p. 83.

140 . cit., p. 91 .

15 Dennis W. Brogan, The Era of Frank1in D. Roosevelt (New Haven: Yale University Press, 1950), pp. 176, 167. 
custom homes and to a limited extent were involved in offering plan and design books. Housing reform and the search for a solution to providing healthy low-cost homes for all was a populist goal which inspired many architects and home economists to discuss the question, offer solutions, and design model home plans for builders. Housing was recognized as a major industry in the United States, and efforts continued to promote home building and buying.

Before the Great Depression, most architects maintained a disdain for designing small homes. Private home design, then as now, was frequently unprofitable, the clients more difficult to work with, and the work for the architect just as hard as for larger buildings; however, there was some continuing interest among certain architects in home design as a problem which challenged their abilities. Architectural journals maintained a continuous reportage on home design questions and the work of architects who were particularly notable for their home designs. Architect Frank Lloyd Wright designed a series of builders' houses for American Homes in Wisconsin.

American Builder magazine, a national journal of the home building industry, and many local publications offered architect designed home plans. Some architects continued the 19 th century practice of publishing house plan books and offering stock home plans and specifications at very low cost to home builders. These publications helped to 
disseminate popular styles and tastes countrywide, insuring a nominal uniformity of house plans and styles from coast to coast with only superficial regional differences in certain building elements, such as larger verandas in the southeast

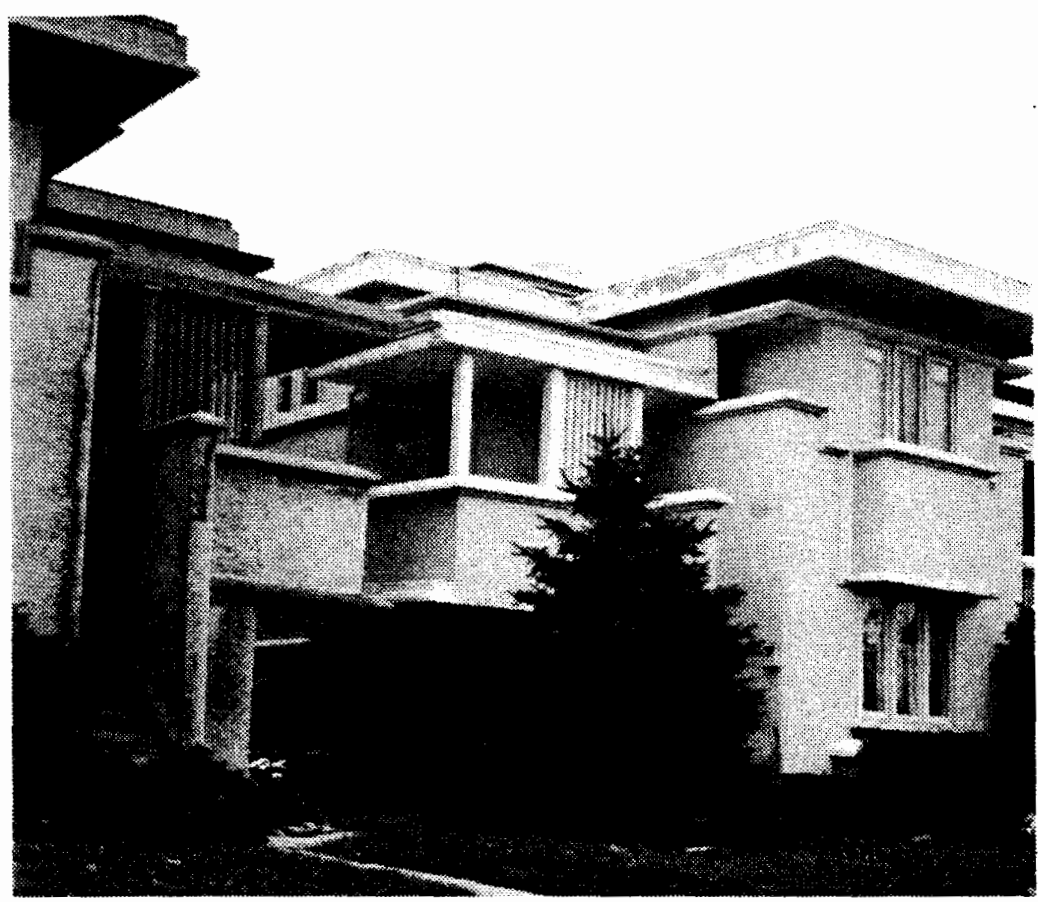

Figure 6. Frank Lloyd Wright designed pre-cut house for American Homes, Milwaukee, Wisc.

c.1914. Typical Wrightean decorative details are nailed onto a basically common bungalow.

and preferences for masonry over wood in some areas.

There were architects who specialized in homes. Among these, the English Arts and Crafts influenced country house was a most popular model for house designs in the 1920s. Builders' houses followed the architects' lead with simplified versions of the Country House and various other romantic styles. These English Arts and Crafts Country 
Houses remain today as some of the most desirable residences. 16

THE INTERNATIONAL MODERN STYLE \& SMALL HOMES

The public is not yet ready for houses of this type (Modern), although indications throughout the entire art and commercial world lead us to believe that eventually houses in the modern spirit adapted to our own mode of living will be much more numerous. 17

Modern Architecture or The International Modern Style was not totally excluded from builders' house designs, however, its influence was very 1 imited. The 1932 Museum of Modern Art's International Exhibition of Modern Architecture introduced the concepts and ideals to most American architects. The program and later book on the exhibition by architectural historian Henry-Russel Hitchcock and the young architect Philip Johnson were widely publicized and read. If not converted, architects knew about the modern movement and its goals. 18

16 Ann Brewster Clarke, Wade Hampton Pipes (Portland: Binford \& Mort Publishing, 1986). Wade Pipes' houses and those by E11is Lawrence and Jamieson Parker in Portland are among the best examples. They are not exclusive to Portland, but are found nationally by many other architects.

17 Paul T. Haagen, "What is this Modern Trend?", Pp. 218, 219, American Builder Year Book: Modern Homes,' Their Design and Construction (Chicago: American Builder Publ. Co., 1930).

18Helen Searing, "International Style: the Crimson Connection," Pp. 79-91; Richard Guy Wilson, "International Style: the MOMA exhibition," pp. 92-104; and, Robert A. M. Stern, "International Style: Immediate Effects," Pp. 106- 
Almost all American architects had learned their profession either in one of the Beaux-Arts structured architectural schools or by apprenticing to an architect so trained.19 The International Modern Style was confined to a few architectural leaders who were attracted to it because it provided a way out of eclecticism, it was a natural development of the Arts and Crafts emphasis on honest materials and the artisan, and it sought to reconcile architecture with the Industrial Age. There was an element of social reform associated with modern architecture which attracted those architects who saw solutions to social ills in honest design, the uplifting of man through better environments and designed order.20 The International Modern Style before 1934 is generally limited to a few custom homes

109 , Progressive Architecture, February 1982. "International Style: a Lively Dissection Fifty Years Later," Pp. 9-11, 14, AIA Journa1, June 1982 .

19 Beaux-Arts refers to the Ecole des Beaux-Arts, Paris. Its architecture program emphasizes the study of Classic and Renaissance forms, formal composition, and a rigid academic approach to design. Its influence dominated architectural education and design in early twentieth century and lends its name to the style of architecture most usually employed for major public buildings between 1893 and 1940 .

\section{Montgomery Schuyler, American Architecture and other} Writings, ed. Wm. H. Jordy and Ralph Cole, 2 vol. (Cambridge: The Belknap Press of Harvard U. Press, 1961). Schuyler was an architectural critic and writer who published essays on design from the 1880 s to $1910 \mathrm{~s}$. His sharpest criticisms were directed to Beaux-Arts academicism; and he was among the first to support Modern Architecture, particularly the work of Frank Lloyd Wright. There were other numerous writer exponents of the Modern, including Wright. 
for the avant-garde and to some early experiments in industrialized home building.
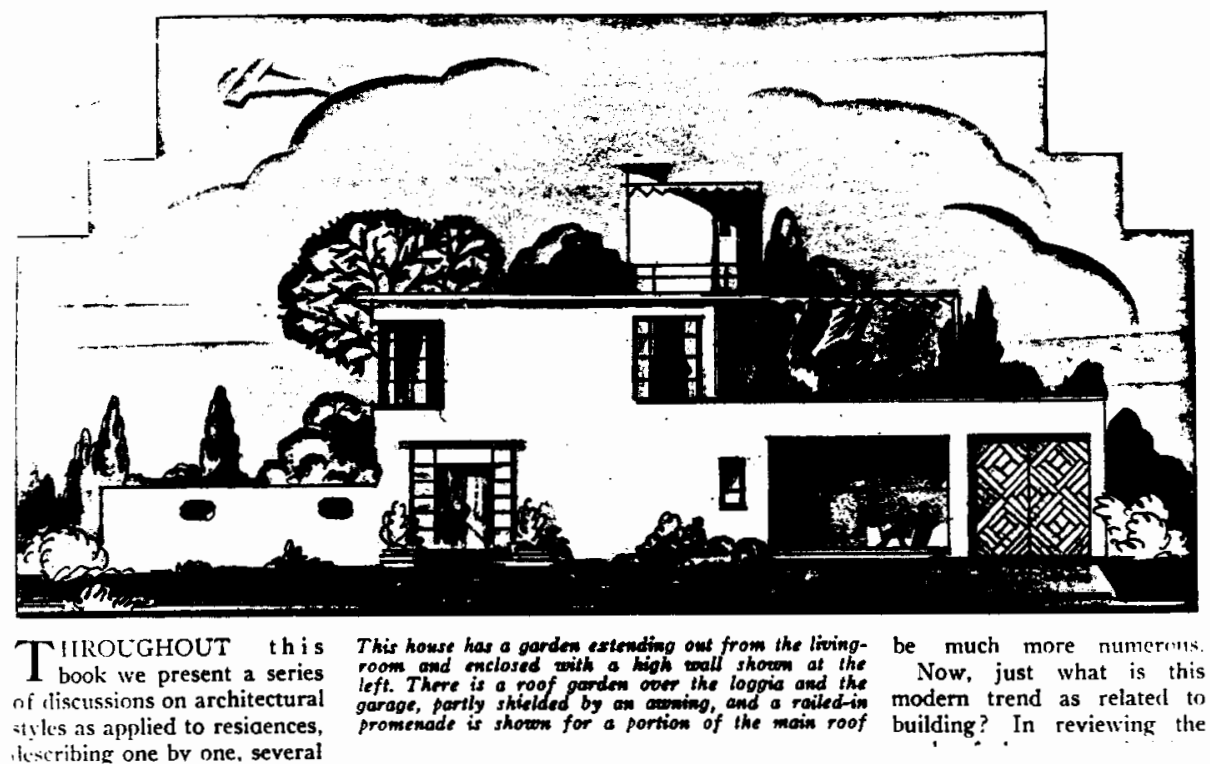

Figure 7. Illustration from American Year Book: Modern Homes, Their Design and Construction, "What is This Modern Trend?"

Early attempts at Modern Architecture appear embarrassingly awkward. The American architect who was academically trained and who understood the classic orders did not understand the modern order, the basic design fundamentals of International Modern architecture. The bias of architectural historians toward the influences of Frank Lloyd Wright, Louis Sullivan, and other architectural leaders obscures the more effective influence of the dissemination of architectural designs throughout all the western nations by means of the journals, books, and travels of the profession and its architects. Most architects were not adverse to designing in any style that a client would like or 
accept. As Portland architect Richard Sundeleaf admitted, he designed homes in any style that the owner wanted; and typical of architects trained in the early twentieth century, he was capable of designing in any of the traditional styles.21 Sundeleaf made the transition from academic to modern more skillfully than most of his contemporaries and became especially recognized for his International Modern Style buildings.

\section{NEW TOWNS AND SMALL HOMES}

Because new towns were related to progressive housing reform and were architect designed, the late 1920 s and Depression examples in the United States were show cases of small homes' architecture. American new towns were influenced by their English and German counterparts. The housing of urban workers in Europe following World War-I was a need which was met, particularly in Weimar Germany, by modern houses and apartments which were widely publicized and discussed with interest in architectural journals. Such housing was advocated as offering economy, more healthful amenities, and as being more compatible with industrial progress. Only a minority of any city's homes showed the influence of European modernism, but sometimes these were

21 "Richard Wilhelm Sundeleaf (1900-1987)," transcript of oral history interview with architect by Linda Dodds and Alfred Staehli, Oregon Historical Society, November 1982. 
noted as being among the "...best designed homes in this section."22 For most architects, the Modern was just another style for their pallet, not a cause, and not one of the more popular styles.

The new town of Radburn, New Jersey, was the first development in America conceived as following the precepts of Ebenezer Howard's Garden Cities. Designed in 1928 by architect/planner Clarence Stein and planner Henry Wright, Radburn was to be the town for the Motor Age. The curvilinear road system and super blocks of Radburn departed from the grid plans customarily used before; although many of the Olmsteads' city plans and subdivision plats also eschewed the grid many years before Radburn. Radburn's housing designs remained within the prevailing traditional styles, not modern. 23

Along with the new towns movement, there was a new interest in discovering the roots of American homes, towns,

22 Frank Calvert, ed., Homes and Gardens of the Pacific Coast, Vol. 1, Seattle, orig. 1913 (Seattle: Christopher Laughlin, Historic Preservation Committee of Allied Arts of Seattle, republished 1974). The home of Mr. A. S. Kerry, shown toward the end of the book, is clearly a Modern building among more typically eclectic ones. It might be called Prairie Style, but that presumes that the style's elements are peculiar to the Midwest and Frank Lloyd Wright in particular without recognizing the common German, Austrian, and English precedents. I believe the same is true for the John Bennes' houses in Portland. Even an ordinary local journal of house design, The Home Designer (Oakland, Calif., 1922) shows a Modern influenced cottage on p. 37 of the February issue.

23 American Institute of Architects, James Bailey, ed., New Towns in America (N.Y: John Wiley \& Sons, 1970), p. 8 . 
and early lifestyles. The Rockefeller financed restoration of Colonial Williamsburg, Virginia, was begun in 1927 and was to have a significant influence on popularizing the Colonial Revival style for home designs. In a sense, Williamsburg also may be looked at as having had a new towns influence---the restoration created a show case Colonial new town out of 150 years of accumulated buildings. Colonial Williamsburg in combination with the White Pine Series Monographs created a powerful interest in the American Colonial Revival style as the appropriate symbol of correct American housing.

\section{BUILDING INDUSTRY DEVELOPMENTS}

Throughout the first two decades of the twentieth century, the American building industry's manufacturers were beginning to develop and produce new materials and systems. These were directed toward increasing markets and profits and also to lowering home building costs through new systems of labor saving, efficient, and industrialized building. Many new building materials were introduced which sought to utilize former waste products and to exploit new material products, and which were thought to be a replacement for more labor intensive field building practices. Some of these were various types of composition shingles and other roofing, wallboards, insulation products, plywood and hardboards, precast concrete products and masonry units, 
terra-cotta building units, metal doors and sash, a limited number of early synthetic resin plastics, and a whole range of innovative mechanical and electrical devices and equipment for homes, and a variety of experimental building

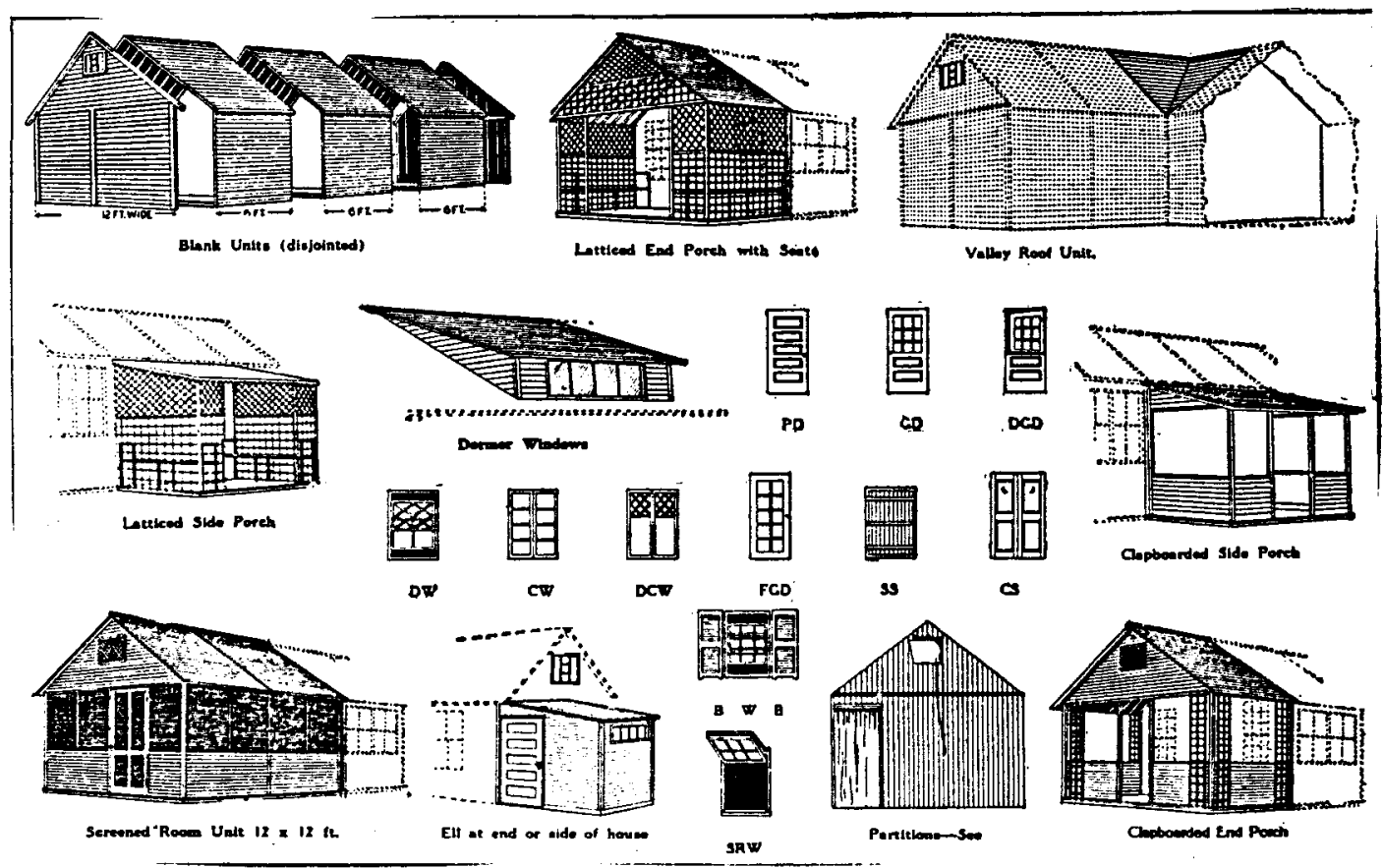

Figure 8. Early prefabrication example from Home Owner's Handbook, Austin C. Lescarboura (N.Y: Sci. American Publ., Co., 1924).

systems employing some degree of prefabrication or a combination of several previously developed processes into one. Some of these innovations were gradually accepted, some were failures, and many had to wait for acceptance until conditions were more receptive. Most of the innovative building systems and applications of the new building panel and board products were closely linked to the acceptance of the International Modern Style. 
The portland cement industry was one which attempted to innovate in the low-cost home market with limited success. The cement house never achieved the popularity of the cement block masonry house. The cement masonry unit house type was much more widely promoted, particularly as a do-it-yourself building method. It was only necessary, so the advertisements read, to use the aggregate found on the site, some portland cement, water, and an Ideal Concrete Machine, available by mail-order or at the hardware store, and anyone could become a house builder and build sanitary, fire safe, and economical homes. 24

Prefabrication and systems building remained a dream, because it either resulted in a drab, unattractive, uniform, non-traditional appearance or, more importantly, it never was able to achieve the economies and maintain the quality standards promised compared to field built homes.

In the area of wood products, there was leadership backed by money which was able to develop and produce some new building products which found limited acceptance in home building and eventually played major roles in changing building practices and influencing house styles. The

240 swald C. Hering, Concrete and Stucco Houses (N.Y: Robert M. McBride \& Co., 1922). William A. Radford, Cement Houses and How to Build Them (Chicago: Radford Architectural Co., 1909). And, various articles in The Cement Era (Chicago: The Cement Era Publishing Co., monthly, June 1906 to Dec. 1908 collected copies). These are just a few of the possible references. 


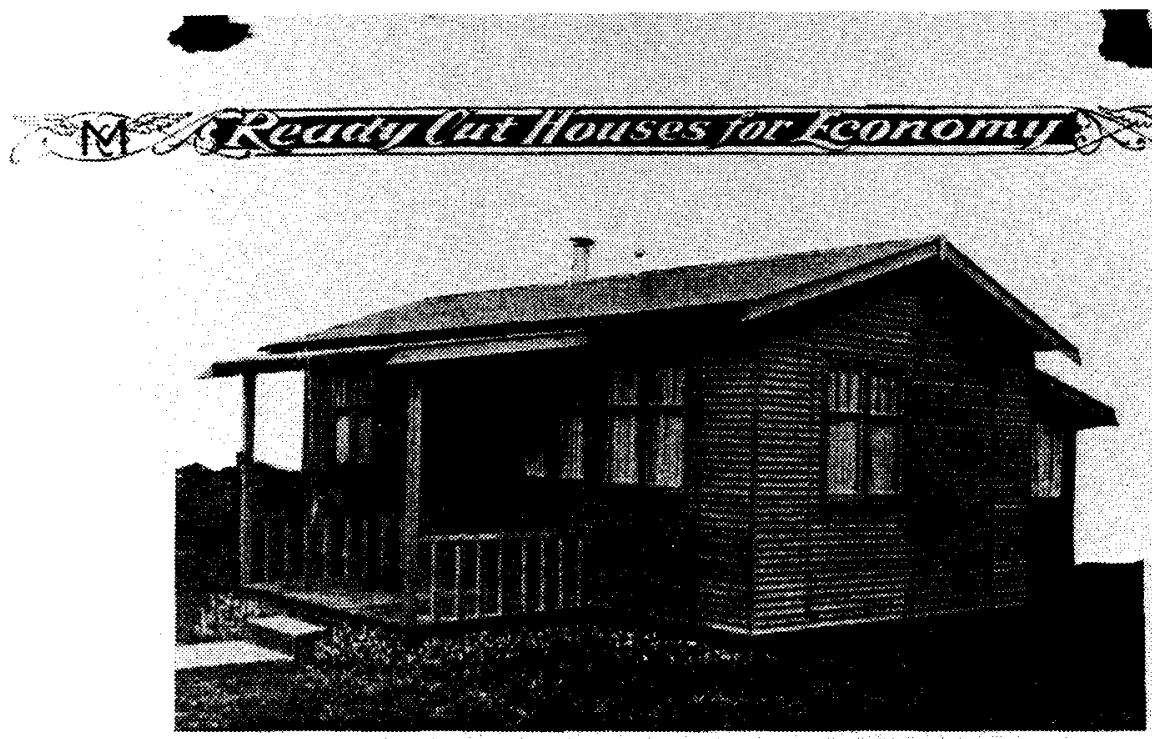

\section{MILLMADE SECTIONAL HOUSE}

Model No. 226-P

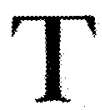

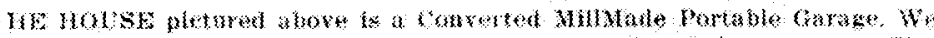

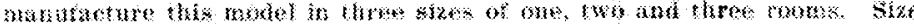

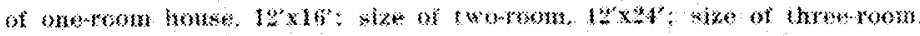
$12 \times 3 e^{2}$

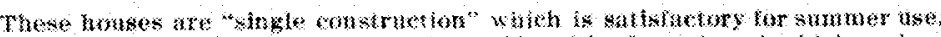

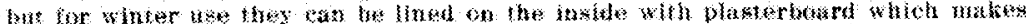

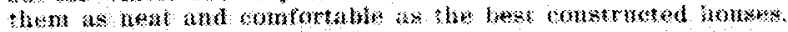

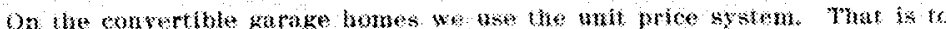

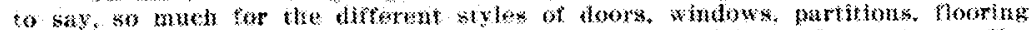

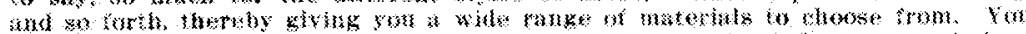

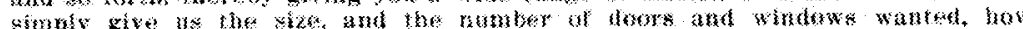

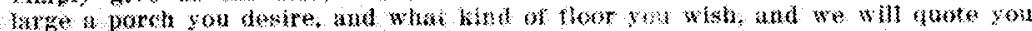
prices.

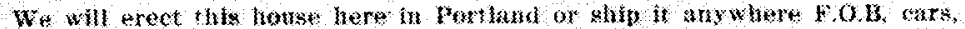

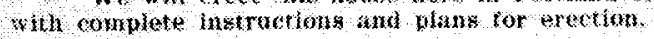

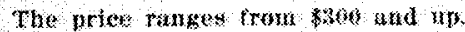

\section{ELWOOD WILES \& SON \\ Bo2 TITLE GQ TRUST BUILDING \\ TELEPHONE MAIN $4: 24$ \\ PORTLAND, OREGON}

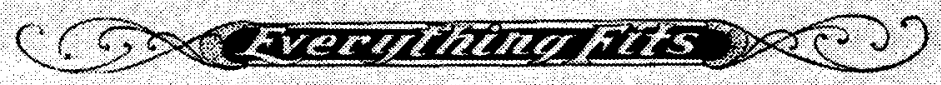

Figure 9. Examples of Portland prefabricated house models. These are pre-cut types and not truly prefabricated houses. Their construction did not meet later home building code standards. 
Weyerhaeuser companies found that as they cut over first the Midwest then Pacific Coast timberlands, they needed to develop new wood products and utilize wood more efficiently if they were to remain in business. Products such as NUWool, Balsam Wool, Insulite, Celotex (insulation and building boards), improved plywood sheets, pre-painted and primed shingles and siding, and the 4-Square lumber marketing program were begun in the 1920 s in order to hold markets and to continue growth. Without new product development, some of the older Weyerhaeuser plants in the Midwest where there had once been seemingly limitless stands of white pine would have had to have been closed---the white pine was gone.

Possibly the most influential product development promotion in home building was The White Pine Series of Architectural Monographs, sponsored by the White Pine Bureau, St. Paul, Minnesota, with associated Weyerhaeuser companies. The publications were begun in 1915 and completed in 1925. Edited by Russell F. Whitehead, each edition consisted of a scholarly study of a particular aspect of American Colonial Architecture sometimes augmented with measured drawings and suggested building details for contemporary use. They contained frequent competitions for designs demonstrating both the application of Colonial Revival Style design and the use of White Pine and other timber building products. These studies were originally 
sent free to a selected 1 ist of architects and later to a larger 1 ist of architects and designers who had requested them. After 1924, The White Pine Series was contracted to Weyerhaeuser Timber Company as sponsor and a charge of $\$ 2.00$ per year was added. 25

The impact of The White Pine Series was substantial. It was instrumental in making the Colonial Revival style popular across the nation and in providing a convenient and well documented source of instruction in the elements of colonial architecture which could be copied and adapted as each architect and designer needed for his particular house design. It set a standard for designing in the style which provided a uniformity of both designs and design excellence wherever used. Along with the White Pine Series, several other architects developed national reputations for Colonial Revival home design and published plan books illustrating their work. 26 As a result of the White Pine Series'

25 Russell F. Whitehead, ed., The White Pine Series of Architectural Monographs, quarterly, 9 Vol. 1915-1924 (St. Paul: White Pine Bureau). Whitehead attempted to republish the series for private subscription sale after 1924 but was unsuccessful. The Weyerhaeuser Company helped settle part of his debts in 1950, but shortly thereafter, Whitehead died, broke, in Albuquerque, New Mexico (Letter from T. L. O'Gara, W.T.C., 5 Nov. 1962; W.T.C. Archives, Tacoma, WA. ).

26Gilbert Murtagh, Small Houses (N.Y: Doubleday, Page \& Co., 1924). Gilbert illustrates his book with his own designs and drawings. Many other notable architects, Milton Grigg and Royal Barry Wills, have their house designs regularly shown in the early plan books. 


\section{The WHITE PINE SERIES of EARLY AMERICAN DOCUMENTS}

Wib Mrasumed DRA wings from

The Geerge IF Lindsay Collection

\section{The ROCKINGHAM MEETING HOUSE ROCKINGHAM, VERMONT}

In Windham County, near Bellows Falls

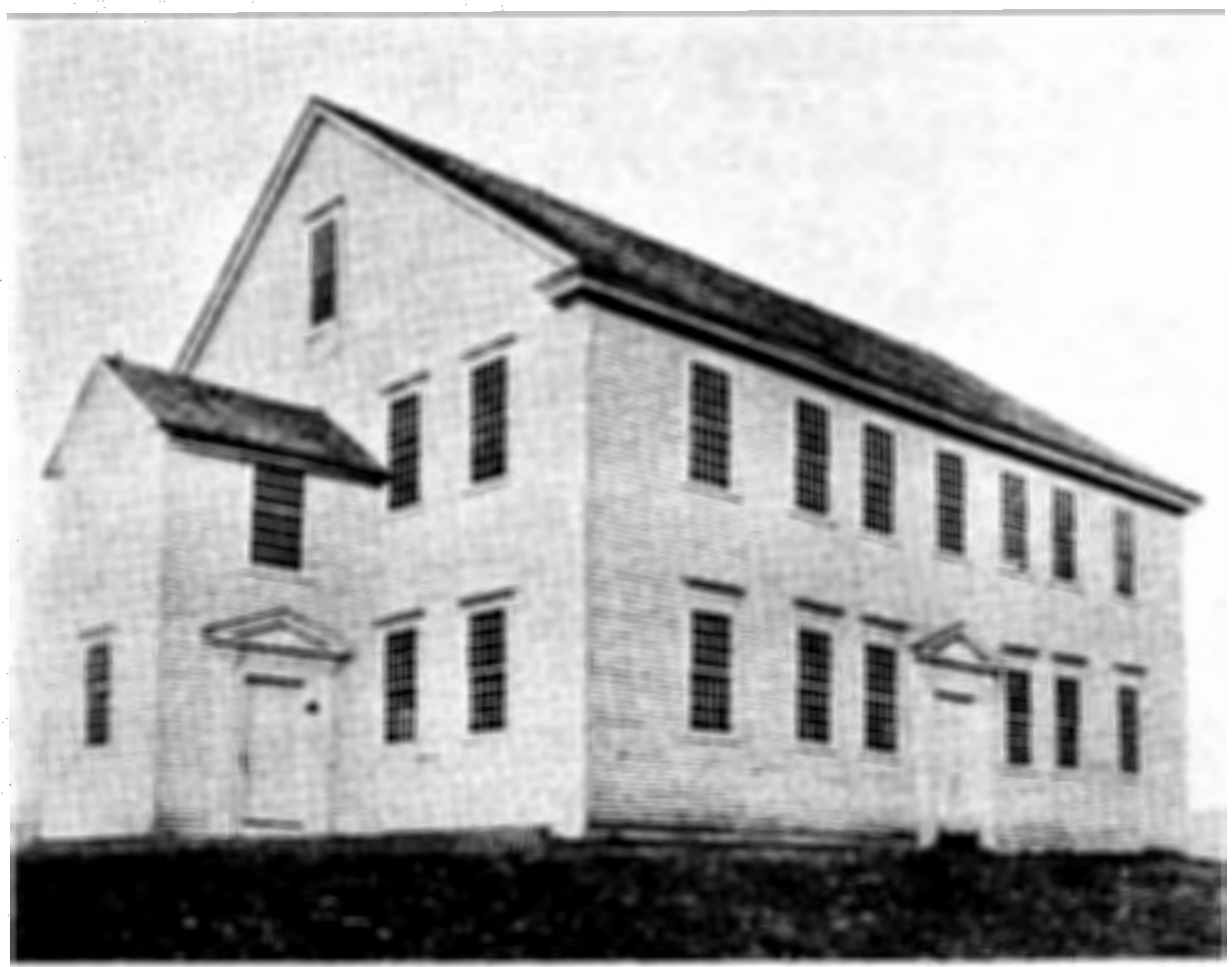

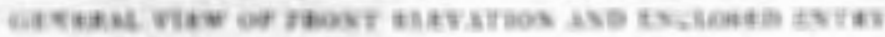
|bs|

Figure 10. Photograph plate from White Pine series. Vol. XIII No. 6 (1927). 


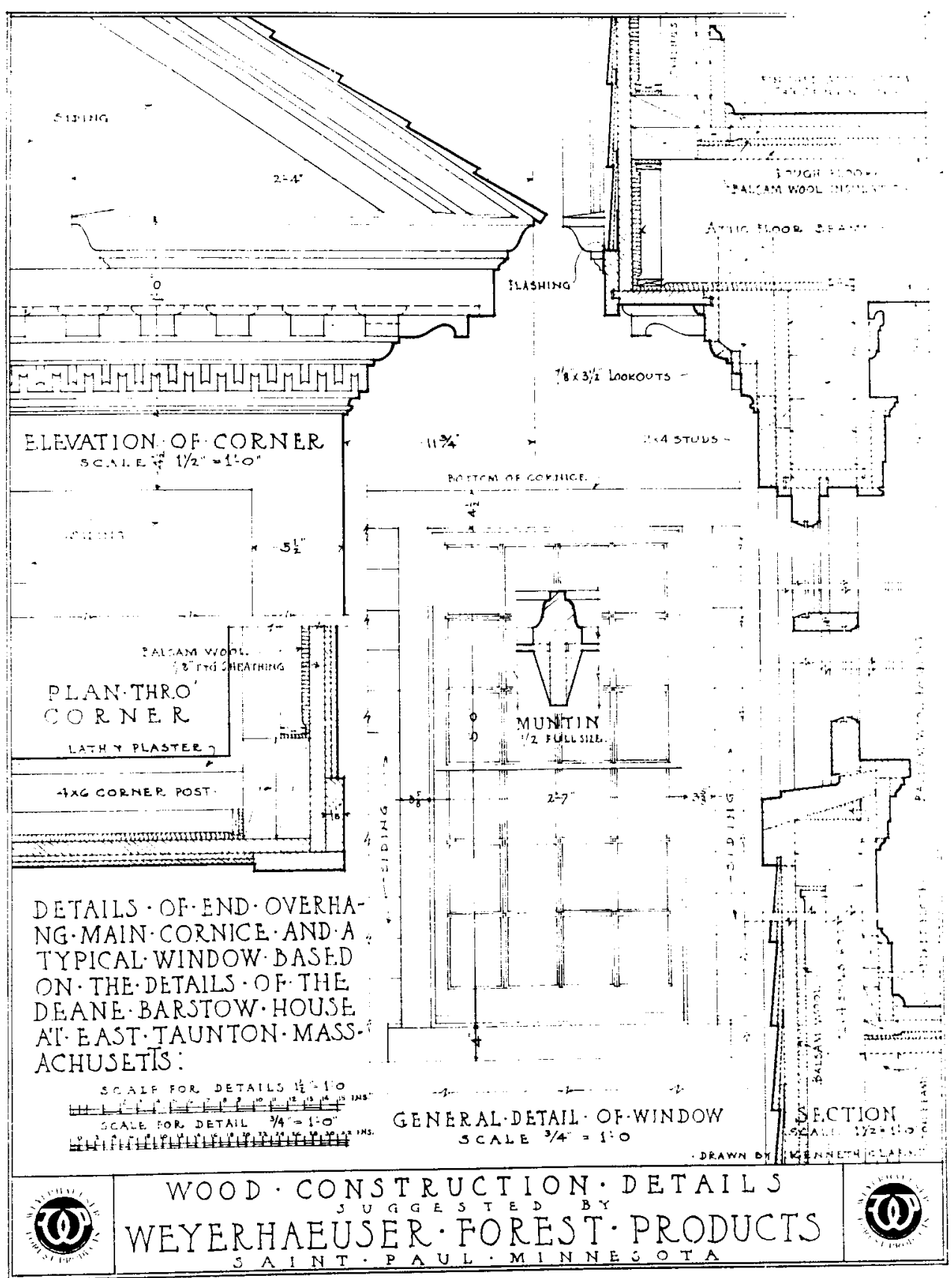

Figure 11. Typical detail from a measured drawing in White Pine Series. Vol. XIV No. 1 (1928). 
publication and of the architects' home designs founded in it, American Colonial Revival style became the accepted national style which was employed more often than any other style, with more consistency, and which has remained one of the most popular house styles to the present day---although now mostly in builders' vernacular versions, since few or no current architects are willing and have the academic training to undertake a project in the Colonial Revival Style with success. The sponsoring Weyerhaeuser's products are conspicuously identified in The White Pine Series' recommended details.

In the Pacific Northwest, building industry associations also promoted home building and the use of their materials. The West Coast Lumbermen's Association and Red Cedar Shingle and Handsplit Shake Bureau offered information on their products and advertised extensively in popular and trade magazines. The Lumbermen's Association booklet of small homes designs in 1933 shows a series of Colonial Revival style based cottages which are both attractive and economical. The booklet also shows illustrations of larger homes but without plans. 27

27 WCLA, Four Low-Cost Homes of Architectural Merit, 1933 Models (Seattle: West Coast Lumbermen's Association, 1933). 


\section{GOVERNMENT HOUSING PROGRAMS}

The federal government did not substantially influence or intervene in the housing industry before 1934. In 1892, Congress first appropriated money for the investigation of housing conditions in American cities and their slums and tenements.28 The government participated in housing studies during the Progressive Era but without substantial results. The need to house workers in war industries for the First World War introduced the government to direct intervention in home building. The United States Housing Corporation became the executing arm of the United States Shipping Board, Secretary of Labor, and Bureau of Industrial Housing and Transportation for the purpose of acquiring land, planning housing developments, and building the homes needed to house the influx of workers at key war industry sites, particularly for ship building. Planning began in 1917, the Housing Corporation was organized in 1918 and was disbanded a year later. Some 47 developments were built using standard designs intended to remain for permanent housing and private sale as soon as the war was over and government ownership was no longer needed. Puget Sound Navy Yard,

28Housing a Nation (Washington: Congressional Quarterly Service, 1966), p. 3. 
Bremerton, Washington, was the only Pacific Northwest insta 11 ation. 29

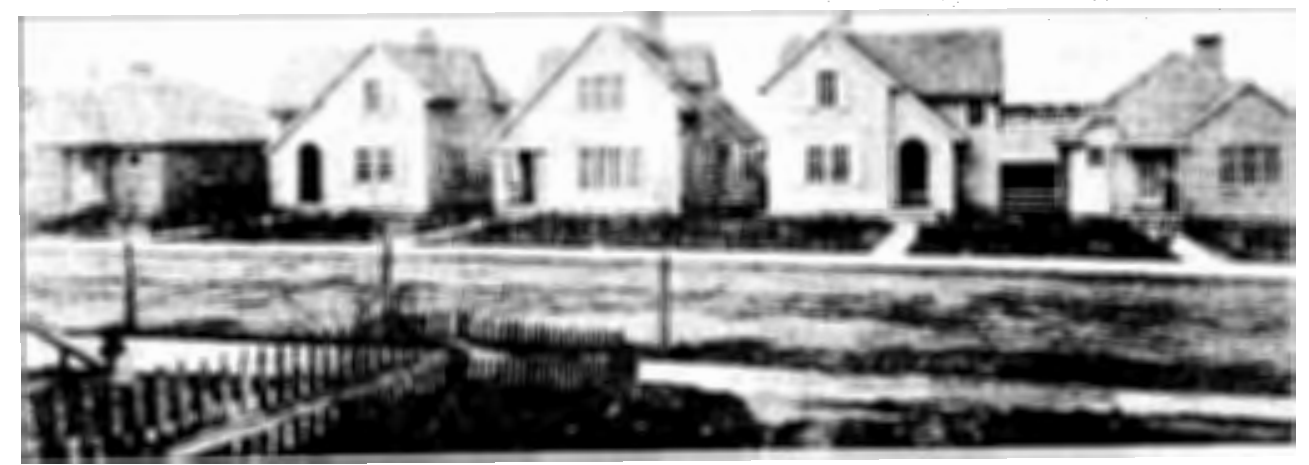

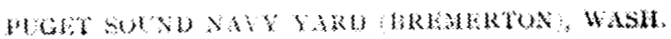

Figure 12. Puget Sound Navy Yard, Bremerton, Washington. Photo from USDL Report of US Housing Corp., 1919.

In justification for the program, the brief introduction to the U.S. Housing Corporation report states that the housing shortage was not a new thing:

The war simply localized and aggravated a widespread, chronic, and steadily growing trouble of peace times, which still persists, and which the country must now face and deal with in general ways better adapted to the nature of American institutions than were some of the arbitrary methods of local relief adopted under the pressure of war.

${ }^{29}$ Department of Labor, Report of the United States Housing Corporation, Vol. II, Houses, Site-Planning, Utilities (Washington: Government Printing office, 1919). 


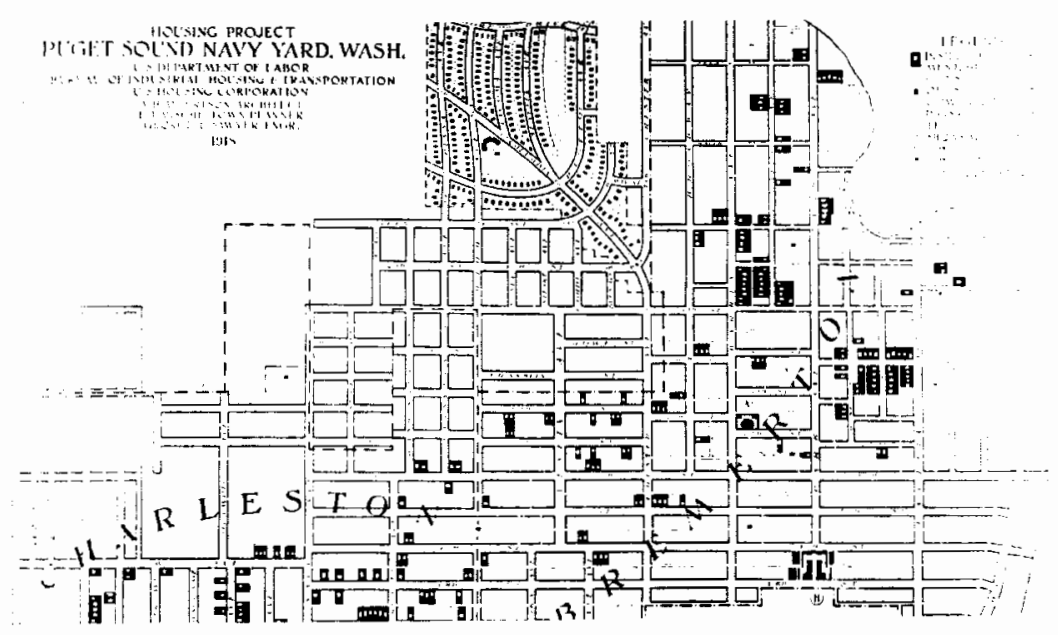

Figure 13. Plan of Bremerton Housing. From US Housing Corp. report.

The report also attributes much of the reported housing need to higher prices due to the installation of ". . expensive sanitary sewerage, modern plumbing, water supply, and heating (which) have come to be considered the essentials of any ordinary house." The arguments are not very penetrating, indicating some lack of concern over many good housing standards which were considered to be important by the leading housing reformers of that time and which are now considered to be normal good practice.

THE HOME BUILDING BOOM IN THE TWENTIES

In the decade following World War-I, America embarked upon an era of optimism and growth. New home building achieved an unprecedented peak in 1925 of 1,048,000. units, 
a total not equaled until after World War-II. 30 However, the boom was about to end, home building leveled off and declined in the following years so that in 1928 and 1929 there were again conferences on the housing problem and on proposals to get building stimulated. The decline in home building was largely attributed to the withdrawal of savings from lending institutions for other investments, leaving no
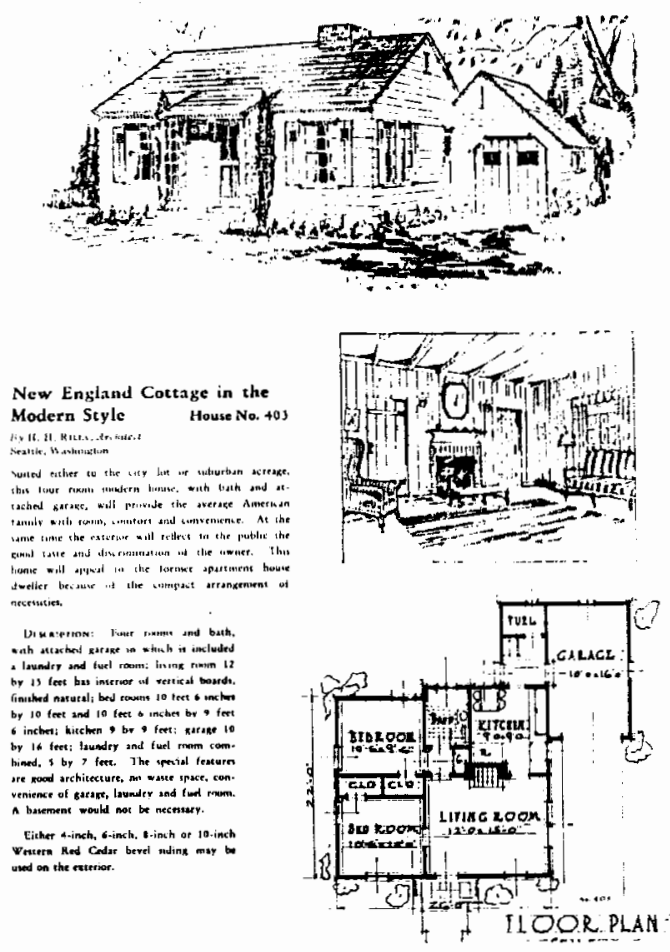

Figure 14. A well designed, compact, 1933 house plan from the WCLA booklet.

money for mortgages. In 1929 , the stock market crash completed the erosion of available mortgage money by causing

30 Manuel Gotlieb, Estimates of Residential Building, United States, 1840-1939, Technical Paper 17, National Bureau of "Economic Research (N.Y: NBER, 1964), "Non Farm Building." 
wholesale foreclosures and collapsing the mortgage markets bringing house building almost to a dead stop. 


\section{A NEW DEAL FOR BUILDERS' HOUSES:}

THE FEDERAL HOUSING ADMINISTRATION

May I draw your attention to some important suggestions for legislation which should tend to improve conditions for those who live in houses, those who repair and construct houses, and those who invest in houses?... The purpose of the program is twofold: first, to return many of the unemployed to useful and gainful occupation, second, to produce tangible, useful wealth in a form for which there is great social and economic need. The program consists of four major, interrelated divisions: Modernization, repair, and new construction; (2) Mortgage insurance; (3) Mortgage associations, and (4) Building and loan insurance. 31

There was a shortage of affordable housing for low and moderate income families when the 1929 depression began.

There has always been a shortage of such housing; but the impact of the normal shortage compounded by a virtual cessation of all home building and the related unemployment in the home building industries focused more than the usual attention on the problem. Even in the 1925 peak of home building, it was never claimed that the need for new homes had been met, only that progress was being made. After 1925

31Frank1in D. Roosevelt, "Recommendation for Legislation to Provide Assistance for Repairing and Construction of Homes," message to Congress on 14 May 1934, The Public Papers and Addresses of Franklin D. Rooseve1t, Vo1. 3 (N.Y: Macmillan Co., 1941). 
housing starts declined year by year as mortgage money was moved into the speculative stock and bond markets. In 1930, 330,000 new homes were started, 254,000 in 1931, 134,000 in 1932, and down to the irreducible minimum of 93,000 in.1933, still an a11-time low and a 90 percent drop from 1925.32 In 1931, President Herbert Hoover, who as a very young man had been a real estate developer in Salem, Oregon, reacted to the plight of the housing industry and the need for homes and shelter by convening the President's Conference on Home Building and Ownership. He was supported by community, labor, church, and other civic organizations throughout the country which were interested in promoting low-rent public housing and urban renewal programs.33 There was no reported effect of this conference other than as its laying, to some extent, the foundation for later New Deal action. In a sense, Hoover's Conference on Home Building was a continuation of the growing revolt against the cities and their slums and the movement toward the suburbs which the Federal Housing Administration would stimulate after World War-II. City Planner Jane Jacobs characterized Hoover's opening remarks at his conference as, "...a polemic against the moral inferiority of cities and a panegyric on the moral virtues of simple cottages, small towns and

$32 \mathrm{Joseph}$ B. Mason, History of Housing in the U.S., 19301980 (Houston: Gulf Publishing Co., 1982), Pp. 7, 8 .

33Housing a Nation (Washington: Congressional Quarter1y Service, 1966), p. 6 . 
grass." 34

Joseph Mason, a former editor of American Builder, credits President Hoover, in part, for at least beginning the dialogue on finding a better way to build and finance housing in the United States and for regenerating the industry. That a home building and financing system might be devised which would make it as easy to buy a house as a car was believed, according to one conferee's recommendation, to be too radical for Hoover to embrace but the seed was planted.35 Before the housing construction problem could be addressed, it was necessary to stem the flood tide of home mortgage foreclosures. The financial plights of homeowners and lenders produced cycles of repossessions for nonpayment of interest and principal and then no money to repurchase the homes taken by the lenders, making those properties worthless to the banks and speeding the banks' own bankruptcies. Hoover's next step in his program to halt foreclosures and bank failures and restart home building was to organize the Reconstruction Finance Corporation in 1932; but his actions were overtaken by the election of Franklin Delano Roosevelt and the Democrats' New Deal.

34Jane Jacobs, The Death and Life of Great American Cities (N.Y: Vintage Books, 1961), P. 310.

35 Mason, History of Housing, PP. 8,9 . 
NEW DEAL: THE NATIONAL HOUSING ACT OF 1934 \& FHA

President Roosevelt's initial actions to save homes and restore the housing industry were embodied in banking and financing reforms. The Federal Home Loan Bank Act and Home Owners' Loan Corporation (1933) were organized to curb the rising trend of mortgage foreclosures. Public response was generally favorable; the Oregon Journal headlined a story, "Rescue by Roosevelt Uses His Influence to Save HomeOwners from Foreclosure."36 The Public Works Administration concentrated on slum clearance, public housing developments, and other larger public projects. Government's movement into direct housing programs was controversial:

The federal government is preparing to go into the housing business on its own account. Faced by the apathy or hostility of real-estate interests toward proposals for slum clearance and the erection of low-priced, adequate housing for the poor,... (the government is) planning to do it itself...first in Washington, D.C, then elsewhere. 37

Some progress was made with large housing projects, but there were pleas for help with single family home building.

There is disagreement about exactly how and from whose inspiration the National Housing Act of 1934 and its innovative mortgage insurance element grew. Joseph Mason believes that FHA grew from a basic concept of Winfield

360regon Journa1, 10 Aug. 1933, p. 10.

37 "The Week," The New Republic, 24 Oct. 1933, p. 290. 
Riefler's, an economics and statistical expert, who served on a committee with Marriner Eccles, Frank Walker, and others. This committee had been requested by President Roosevelt to study the private housing question and make recommendations. 38 In addition, housing journals pressed for a housing program throughout the winter of 1933-34. Architectural critic, historian, and philosopher, Lewis Mumford may have had a leading role in promoting a New Deal for the private home. Along with architect Albert Mayer and planner Henry Wright, Mumford wrote a series of articles on the need for a housing program and made specific recommendations on its form. In January 1934, he wrote that there was a shortage of 914,000 dwellings, that housing is a labor intensive industry which can put men back to work, and that the ignorance of modern housing methods prevalent throughout America demonstrated the need for a housing curriculum for architects.39 In March 1934, Mumford, Mayer, and Wright concluded their essay series on the housing program with "A Concrete Program" which 1 isted requirements for planning and good design, low cost money, extended amortization periods, abolition of the current usury practices, industrialization of the building process, government administration and direction, and the "Rationali-

\section{Mason, History of Housing, P. 12.}

39Lewis Mumford, "New Homes for a New Deal-III," The New Repub1ic, 31 Jan. 1934, p. 69. 
zation of production at every point." The article proceeds to attack the old system of home building for its lack of planning, exploitation of 1 and and land values, neglect of social values, and failure to train home builders in modern practices. It concludes with seven points for implementing the plan in government structure. 40

It is indicative of the speed with which New Deal programs were conceived and made into law that the National Housing Act of 1934 was passed only three months after Mumford's articles. There is a suggestion by historian Arthur M. Schlesinger in his The Coming of the New Deal that an objective of The National Housing Act's formulators was for it to be a part of the rebuilding of the internal structure of the United States in accordance with the theories of Economic Nationalism advocated by Charles Beard--to avoid European economic and political difficulties by concentrating on internal commerce.41 However and by whom the National Housing Act was conceived, it was moved with great dispatch through the 73rd Congress. Representative Henry B. Steagall led most of the committee work and resolved the combined Senate and House bill differences (mostly money limits and authority). With Steagall on the

${ }^{40}$ Lewis Mumford, Albert Mayer and Henry Wright, "New Homes for a New Deal-IV: A Concrete Program," The New Repub1ic, March 1934, pp. 91-94.

${ }^{41}$ Arthur M. Schlesinger, The Coming of the New Dea1 (Boston: Houghton Mifflin Co., 1959), p. 186. 
committees, were representatives T. Alen Goldsborough, Anning S. Pral1, and Robert Luce, and senators Robert F. Wagner, Alban W. Barkley, Robert J. Bulkley, John G. Townsend, Jr., and Frederick Steiwer (Oregon). The National Housing Act was to:

. ...improve housing conditions; to provide employment; to provide for the insurance of mortgages; to insure the saving in savings-and-loan associations and similar institutions; to amend the Federal Home Loan Bank Act, Home Owners' Loan Act of 1933, the Federal Reserve Act, and the Farm Security Act of 1933; and for other purposes...42

Representative Steagall spoke for the bill as reconciled by the House and Senate committees and gave assurances that the Home Owners' Loan Corporation would be further aided to continue its record of "splendid service" which was essential for the relief of home owners. The bill promised to bring a revival of construction and building activity and would put a substantial number of men back to work. There was little opposition. Representative Luce also spoke for the bill but with reservations about its efficiency---better done by private enterprise. There were expressions of concern that the new Federal National Mortgage Association would be too competitive with private financing institutions and that there would be too much regulation of their businesses.

Discussion of the National Housing Act centered about 
its authority and the possibility of adverse effects on private savings and loan and building and loan associations. The National Housing Conference, National League of Cities, U.S. Conference of Mayors, National Association of Housing and Redevelopment Officials, National Association of Housing Cooperatives, the American Federation of Labor, and Congress of Industrial Organizations lined up in support of the bill. In opposition were the National Association of Home Builders, National Association of Real Estate Boards, United States Savings and Loan League, The Chamber of Commerce of the United States, Mortgage Bankers Association of America, and, surprisingly, the National Lumber and Building Material Dealers Association. 43 The National Housing Act clearly was seen by the established housing industry as being a threat to bring new levels of regulation and control over what had been an entirely free and unregulated industry, albeit a dead one.

Title I of the act covered housing renovation and modernizations and created the Federal Housing Administration. Provisions of the act covered seven items: Authorization for the insuring of banks, trust companies, building and loan associations, personal financial companies, and similar home lenders for their home loans, limited to $20 \%$ of the total amount of loans made for such

\section{Housing a Nation (Washington: Congressional} Quarterly Service, 1966), P. 6. 
purposes, and not more than $\$ 200$ million; (2) The making of loans to housing loan institutions with Reconstruction Finance Corporation to provide the funds; (3) Creation of a mortgage insurance revolving fund to guarantee mortgages for a fee to be between $0.5 \%$ and $1.0 \%$ of the mortgage amount in addition to the interest rate;

(4) Development of $10 \mathrm{w}$ income housing, limited to not more than $\$ 10$ million per project; (5) Creation of the National Mortgage Association (FNMA) to be a secondary market for housing mortgages, freeing the funds of private lenders for additional loans; (6) Creation of the Federal Savings and Loan Insurance Corporation; (7) And, related amendments to the Federal Home Loan Bank Act. Title II was the new homes mortgage insurance program which was implemented about a year later. The National Housing Act was signed by President Roosevelt on 18 June 1934 .

The new housing act met with less than unanimous applause. The New Republic was critical in part, commenting: "At last the long awaited means to stimulate the construction industry..."; but, it continued, the act was not a housing measure as housing was understood then; it provided for long term loans of up to $\$ 2,000$. for modernization and upgrading and for federally guaranteed mortgages.44 TNR sharply criticized the act three weeks later, reporting the opposition from three housing groups, the 
Housing Study Guild, Labor Housing Conference, and Philadelphia Chapter of the Federation of Architects, Engineers, Chemists and Technicians: "...the new law might better be called the 'Anti Housing Act."' The opposition expressed disappointment in the housing law as compared to Lewis Mumford's proposa1.45

FHA IN OREGON AND THE PACIFIC NORTHWEST

The need for some kind of housing program was recognized in the Portland newspapers. The advent of the National Housing Act and its FHA was welcome news. In January 1934, the Oregon Journal carried a headlined story, "The Home Shortage," stating that there was a shortage of 1.5 million units valued at $\$ 4.5$ billion, 80 percent of which was for labor if current building methods were used. The relationship to the depressed Oregon lumber industry was noted. There was no home loan money for building; the savings and loan banks could not help those builders who had survived. 46

FHA issued a first news release announcing its rules for Title I program implementation on 10 August 1934. It was directed to property modernization and rehabilitation and primarily gave information about the making and securing

45TNR, 4 July 1934, p. 193.

460regon Journal, "The Home Shortage," 6 Jan. 1934 , p. 4. The next day, writer David Lawrence expressed skepticism about the new mortgage guarantee plans. 
of loans which the program would guarantee. Two sample forms were attached. The entire document including forms is only twelve pages long---with ample white space. 47

The beginning of the Federal Housing Administration and its effect on builders houses in the Pacific Northwest was modest. FHA began its organization almost immediately after it was signed into law. In Oregon, Portland attorney Edgar Freed was named State Director. Portland architect Jamieson K. Parker, who had joined the FHA staff with Freed, was named Assistant Director in August 1934 with responsibility for Title I, the housing rehabilitation and remodeling program. Later, Parker succeeded Freed and held the post of State Director of FHA until his untimely death in 1939.48 The Oregon regional office of FHA was in the Park Building, Portland. Other western regional offices were located in Seattle, Boise, and San Francisco.

In its first report for the half year of 1934, the new FHA stated that its headquarters staff and the organization of field offices in all states was completed by 15 August

47FHA, "Modernization Credit Plan, Confidential until August 10, 1934." (Washington: Federal Housing Administration). Copy from Weyerhaeuser Archive, Tacoma, Washington.

$48 \mathrm{E} 1$ isabeth Walton Potter, "The American Institute of Architects and the Historic American Buildings Survey in Oregon, 1930-1940," Part I of the paper: A History of HABS and HAER in Oregon, 1933-1983, Elisabeth Walton Potter and Alfred Staehli, for the Oregon HABS 50th Anniversary observance, 1983. Jamieson K. Parker, notes from office correspondence, The Oregon Historical Society archives. 
1934. There had been increases in bank participation from $1 \%$ to $71 \%$; over $\$ 30$ million in loans, for rehabilitation and remodeling projects only, were insured at an average of \$419. principal amount and 28 month terms. Good newspaper coverage had been obtained through separate stories and "Better Housing Sections."49

No new houses were included in those first nine months of operation. Nearly all states had needed to pass enabling legislation to permit investing in insured mortgage loans and to allow for 1 imits on interest. The model was New York's statute Chapter 897, 24 August 1934. President Roosevelt wrote to FHA Administrator James A. Moffett on 1 November 1934 regarding NHA Titles II and III urging the "lowest possible" interest rates:

One of the major purposes of the National Housing Act was to encourage a greater uniformity in mortgage interest rates throughout the country and especially to eliminate as far as possible exorbitant and usurious rates charged in many places. 50

Moffett concurred in a reply to the President, saying that the Executive Council of FHA had recommended $5 \%$ for insured mortgages. He sent a note to all governors with copies of Roosevelt's and his letters attached urging their

\section{${ }^{49}$ FHA, First Annual Report of the FHA, House Document} No: 88, 74th Congress lst Session (Washington: Gov. Printing Office, 1935). National Archives.

${ }^{50}$ Correspondence between State Governors and President Franklin D. Roosevelt Covering FHA Legislation, 1934-35, Washington, National Archives, file NC3-31-77-1. 
immediate attention to the problem of restrictive state laws and the need for legislative action along the lines of the one just passed by New York. Oregon's Governor Julius L. Meier responded that since he was being succeeded by Charles H. Martin in January 1935, he would bring the matter to Governor Martin's attention. Martin followed with a letter on 6 January 1935 reporting that the Oregon legislature would meet soon and decide on the necessary laws. Oregon passed the reform legislation that March, and Idaho and Washington followed. In July, FHA's staff reported that enabling legislation for financing FHA insured mortgages had been passed in all states except three whose legislatures had not met.

At the end of 1935, Administrator Stewart McDonald reported that the initial, Title I, modernization and repair program was continuing. The mutual mortgage insurance plan for one and two family dwellings, Title II, had insured about $\$ 16$ million worth of mortgages with $20 \%$ down payments and 20 year terms: "The plan could not become fully operational until the end of the First Quarter of the year because of the need for new state legislation." The report noted that "Minimum Construction Standards" had been introduced.51 There was an increase of $207 \%$ in the value of building permits reported to the Bureau of Labor Statistics

51 The FHA "Minimum Construction Standards" or "Minimum Property Requirements" are addressed later. No copies of the 1930s' documents were located. 
in 1935 over 1934, greater than any since 1930.52

Records of the Federal Housing Administration in the 1930 s are incomplete. It appears, first, that very few documents were generated. Second, very few of what documents and records there were have been saved. The National Archives and The Library of Congress have only selected portions of the headquarters and regional office records, mostly compilations and published reports, almost none of the general correspondence. Similarly, regional federal records centers have culled their records and eliminated most of the early documents. From those early documents that are available, the early work seems to have been done by exchanges of letters, memoranda, and information sheets, not by published booklets and manuals such as those which appear after World War-II. For instance, the Minimum Property Standards manual which was the "building code" for FHA insured homes after the war, a thick 8-1/2 by 11 inch size loose leaf bound volume, evolved out of the Minimum Construction Standards; none of which were located but which appeared (from references and other early FHA work) to have been a series of information sheets and memoranda similar to the HHFA Technical Bulletin series. 53 The volume of FHA

52 FHA, Second Annual Report of the FHA, 31 December 1935 (Washington: Government Printing Office); National Archives.

53Housing and Home Finance Agency, Technical Bulletin, No. 6, Sept. 1948 (Washington: HHFA). This issue contains technical information and references to other publications 
insured building was small before World War-II and the need for a more encompassing manual of standards may not have been important. After the war, the early Construction Standards seem to have been revised and compiled into a postwar eight section manual. In the late 1940s and early 1950s, the standards were called Minimum Property Requirements and contained much of the same material, organization, and format as the 1960s' Minimum Property Standards which remained in use with periodic revisions until discontinued in 1986.

FHA RESULTS IN THE DEPRESSION YEARS

It (Congress) took definite steps toward a national housing program through an act which I signed today designed to encourage private capital in the rebuilding of the homes of the Nation. 54

Let us ask again: Have we reached the goal of our vision of that fourth day of March, 1933? Have we found our happy valley? I see a great nation, upon a great continent... But here is the challenge to our democracy: In this nation... I see one-third of a nation ill-housed, ill-clad, i11-nourished. 55

Nationally, the Federal Housing Administration program

on building. Bulletin No. 1 was issued November 1947. This example from the collection at the University of Illinois' Smali Homes Council did not give the ending date of the series, but it may have coincided with the first issuing of the Minimum Property Requirements in 1947 or a little earlier.

54Roosevelt, "The First Fireside Chat of 1934," 28 June 1934, Public Papers, Vo1. 3.

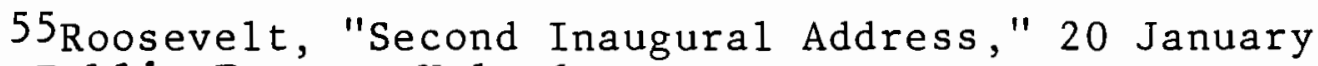
1937, Public Papers, Vol. 6. 
only gradually increased the building of new houses: After a modest start from 1934 to 1936, the slowing or downturn in the Depression recovery in 1937 lost some of the gains which were made. The building tempo resumed once again as the 1930s drew to a close only to be diverted by the military buildup and the United States entry into World War-II. Strong concerns by Secretary of the Treasury Henry Morgenthau and the business community over government spending in late 1935, after talk of the dangers of a new boom in 1936, caused the government to cut back on economic stimulation programs in 1937, since many leaders believed that the depression was nearly over. 56

Home building never did recover until after the war. In 1938, new single family residential building totaled approximately 270,000 units, ten percent more than in 1937, and the largest number of new homes since 1929. This was still less than one third of the peak of almost a million new houses in 1925 and one-sixth of the projected need for new homes. 57

What FHA did accomplish was to put in place a new system of financing private home building which made the purchase of a home as affordable as paying rent and with substantial protections built in against foreclosure. FHA

56Arthur M. Schlesinger, The Age of Rooseve1t: The Politics of Upheaval (Boston: Houghton Mifflin Co., 1960), pp. 510, 511, 571 .

57 FHA, Fifth Annual Report of FHA, Dec. 1938, pp. 6, 7. 
had begun a partnership with the home building industry and with research institutions which was to revolutionize the home building industry in the 1940 s and the following decades along with labor and home market changes. Also, the existence of the program and its influences on the home journals, architects and planners, and the building industry was to spark a decade of serious discussion and planning concerning what should be done to solve the perennial housing shortage, how to make the dream of owning one's own home a reality. 
CHAPTER IV

\section{THE AMERICAN DREAM HOME IN THE GREAT DEPRESSION}

Our little castle with every dream gone, Is lonely and silent, the shades are all drawn. And my heart is heavy as I gaze upon---A cottage for sale. 58

Both the architecture and building press and the general circulation magazines featured articles on low cost housing in the Depression of the 1930s, the usual home plans, decorating advice, and financing of homes. Newspapers ran Sunday supplement sections on new homes. None of this was particularly new, but the changes in home financing and the new government support for home building gave the writers a new approach to housing. As said earlier, the administrators of FHA had expressed their pleasure with the early results and cited the articles as proof of the effectiveness of the new housing laws.

Actual columns of housing news may or may not have increased in number, but what did change was the presentation of housing news and the promise of the availability of new homes for everyone---the affordability of a home. House plans and articles on the new housing programs as well as

58Larry Conley and Willard Robinson, A Cottage for Sale, lyrics and music (N.Y: DeSilva, Brown, Henderson, Inc., 1930). 
featured reports on housing studies and symposiums appeared in almost every newspaper and magazines from Architectural Forum to Country Gentleman. The political spectrum of opinions on homes and the National Housing Act ranged from The New Republic to The Saturday Evening Post. That the dream could become reality was never questioned. Discussion was directed to the form it would take, the economic costs of getting there, and criticism of any failures of either intent or accomplishment.

Typical was The Oregonian's story in 1938, "Home Ownership Campaign is Urged."59 0. V. Bradley, a Portland East Side realtor, advocated an increase in home ownership:

No one can deny that the impetus has been given to home ownership by the events of the past few years. We know that higher interest rates and short-term mortgages with recurring renewal fees and cumbersome second mortgages, tended to prevent home ownership in the past, particularly in the lower income brackets, but the Home Owners Loan Corporation, in the dark days of 1933 , pioneered the way with its lower interest rate and long amortization for urban housing.... Home ownership should be a major community goal.

In that same 1938 number of The Oregonian, on the second page following the report of Mr. Bradley's statement, examples of new home and remodeling designs by Portland architects were featured with information on FHA eligibility. 
dern House Designed fo

Comfort and Convenience Feature This House
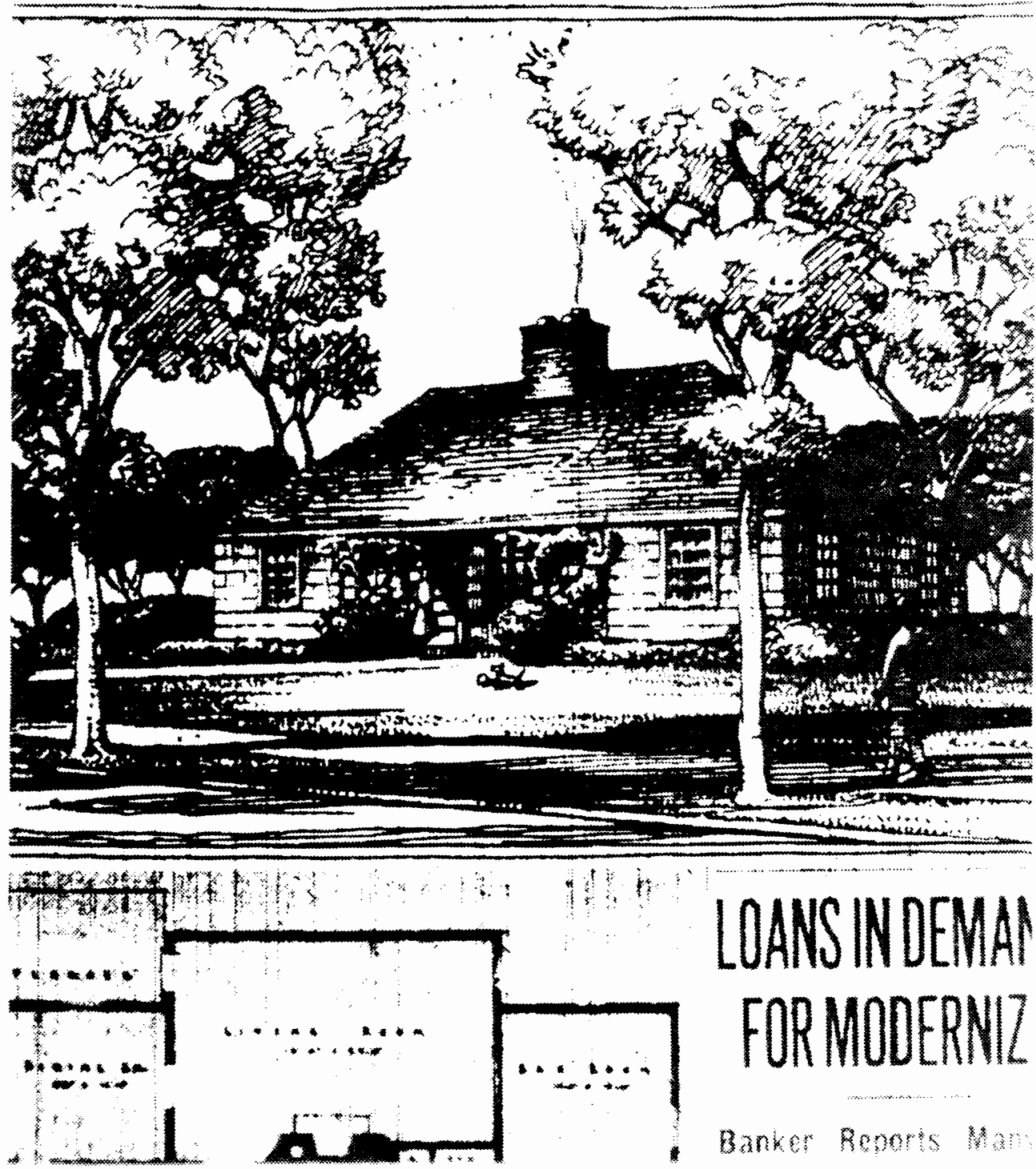

Figure 15. A FHA eligible house design by architect Margaret Fritsch is featured in a 1938 Sunday Oregonian story. A remodeling by architect Richard Sundeleaf is also shown. 
THE ARCHITECTURE OF HOMES AND NEW TOWNS

In the Depression years, there was a heightened interest by architects and planners in low-cost homes, as if all the information on planned and designed housing that held out such exciting possibilities in Europe was now at last applicable to the United states. It is probably realistic also to say that with the unemployment in the architectural profession, home designing for any fee at al1 was better than no work. The Depression gave architects the time to do conceptual studies on homes and to reconsider what a home should be.

New towns as a planning concept and ideal and as part of solving the housing dilemma had been current from the turn-of-the-century following publication of Sir Ebenezer Howard's book, Tomorrow, republished as Garden Cities of Tomorrow. 60 The English New Towns in 1903 and after World War-I were widely studied and published as models for socially desirable housing for workers. New towns in the United States were not started until after World War-I, unless the designed company town of Pullman (1880), I11inois, is counted. The plan for Coral Gables (1921), Florida, was the first built. Longview (1923), Washington, a company town, was very strongly influenced by the New Towns Movement. Perhaps Radburn (1928), New Jersey, was the

60Ebenezer Howard, Garden Cities of To-Morrow, ed. F. J. Osborn (Cambridge: The MIT Press, 1965). 
most influential, although Sunnyside Gardens (1924-1928), designed by planning pioneers Clarence Stein and Henry Wright as a Queens housing development garden suburb of New York City, was begun a few years earlier.61 These early housing and community developments were models for Depression housing programs and influenced the planning of smal1 houses up into the 1950 s.

The Home is bounded not by the walls of the dwelling but by the farthest limits to which family 1 ife extends. Thus the relation of house to lot, to neighboring houses; the relation of 1 ot to $10 t$; and the relation of al to the community is the concern of the architect. 62

Thus began a whole issue of a leading architectural journal devoted to housing and the home. The emphasis was on the small two or three bedroom house in the $\$ 5,000$. to $\$ 6,000$. price (1935) range. Home Owners' Loan Corporation help for banks was featured, but the FHA was too new to have an impact on new homes at this time. Architects took the cue and followed throughout the Depression with their own home books and their contributions to other publications' articles on new homes, their designs, and their costs. The issuing of home plan books was a continuation of the previous nineteenth and earlier twentieth century plan book

61 "Sunnyside Gardens Renewed," Progressive Architecture, Nov. 1986, P. 47. Also, AIA, New Towns in America .

62 Architectura1 Forum, May 1935 (N.Y: Rogers and Mason. Corp.), p. 23. 
practices but with more emphasis on the architects, planning for modern liveability, and finance planning.

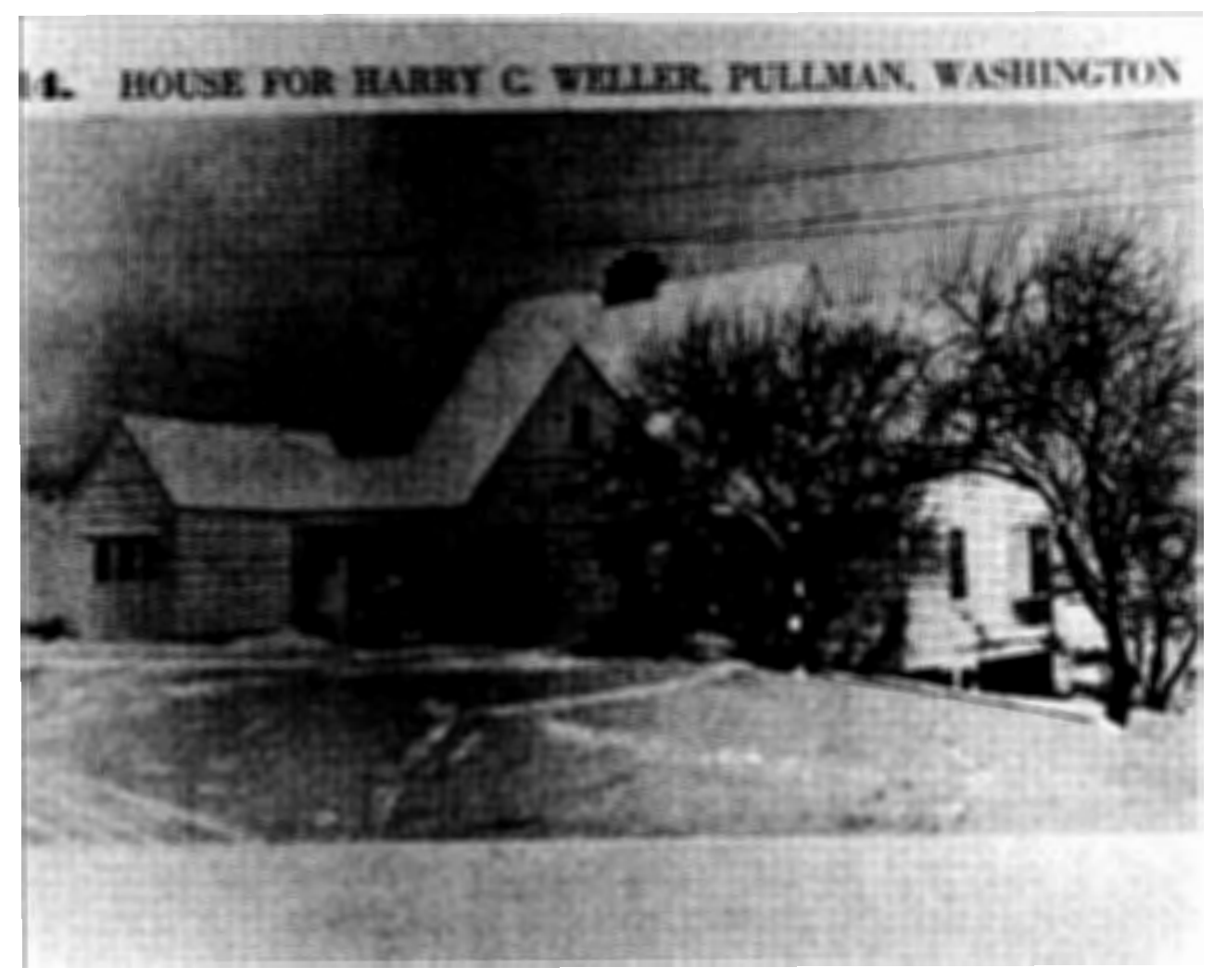

Figure 16. House for Harry C. Weller, architect, Pullman, Washington. Forum, 1936 Book of Small Houses.

The Architectural Forum led the departure from the traditional styles of the past. Its 1936 home plan and planning book, The 1936 Book of Small Houses, 63 was dedicated,"...to the art of living and to the profession that has contributed most to it---architecture." Designs range from traditional Colonial Revival Style to the International Modern. No Oregon architects are represented in the book,

${ }^{63}$ The Architectural Forum, The 1936 Book of Smal1 Homes (N.Y: Simon and Schuster, Inc., 1936). 


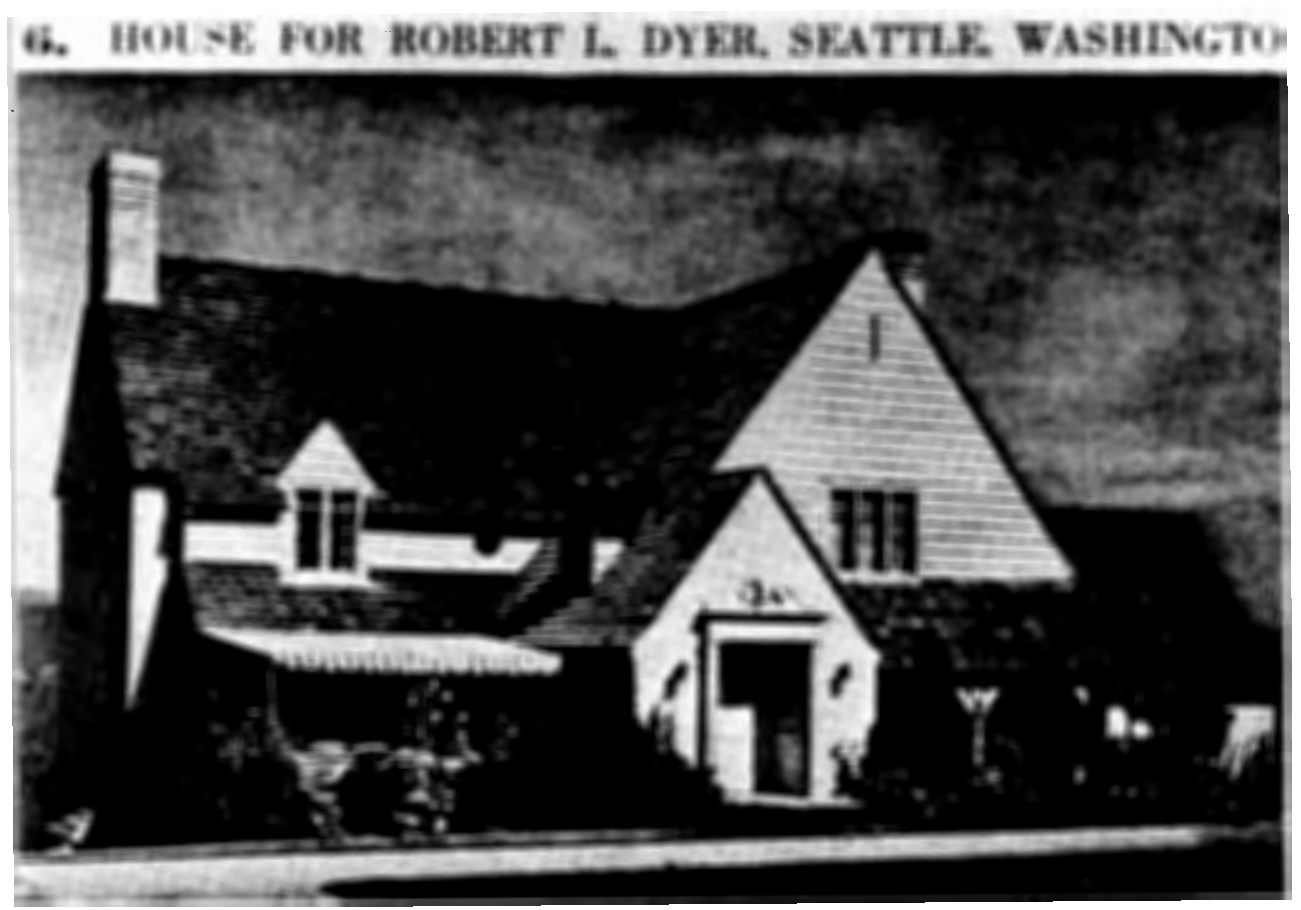

Figure 17. A 1936 Forum house by George We1lington Stoddard, architect, Seattle.

but Seattle architect George Wellington Stoddard has three designs and Pullman, Wash., architects Smith and Weller have one. California is well represented with traditional

designs, Modern Ranch Style, and one International Modern by Richard J. Neutra. The Book of Small Houses is a true manual on home design and planning. It includes a bibliography of other homebuilding books, one of which is by Lewis A. Coffin.

Coffin's American Country Houses of Today, 64 is more typical of house books, showing photographs and plans of its

64Lewis A. Coffin, American Country Houses of Today (N.Y: Architectural Book Publishing Company, Inc., 1935). 
examples, but with no other planning information. The styles are predominantly traditional ones; large Tudor Revival, English Arts and Crafts, and American Colonial Revival, but also a few Modern and California Ranch Modern are represented toward the back. Both Coffin's and Forum's plan books show designs by two of the leading American Colonial Revival architects, Royal Barry Wills and Milton L. Grigg, who would produce their own plan books in the 1940s, and whose FHA insured mortgage houses would be selected as examples of the success of the government program in 1938 .

Two later books, Planning Your Home and Plan Your House to Suit Yourself,65 are very definitely how-to-do-it type books, offering guidance from needs assessment to negotiating with a contractor. Neither book is a plan book, although some house photos and plans are shown; rather, they concentrate on fundamentals. Both might be used by prospective home builders and by architects wanting to learn more about house design and meeting client needs.

Possibly the most significant activity by architects in the Depression which would have a lasting influence on home architecture, continuing into the last half of the century, was the Historic American Buildings Survey (HABS).

65Emanue1 E. Erickson, Planning Your Home (Peoria: The Manual Arts Press, 1938). Tyler Stewart Rogers, Plan Your House to Suit Yourself (N.Y: Charles Scribner's Sons, 1938). 


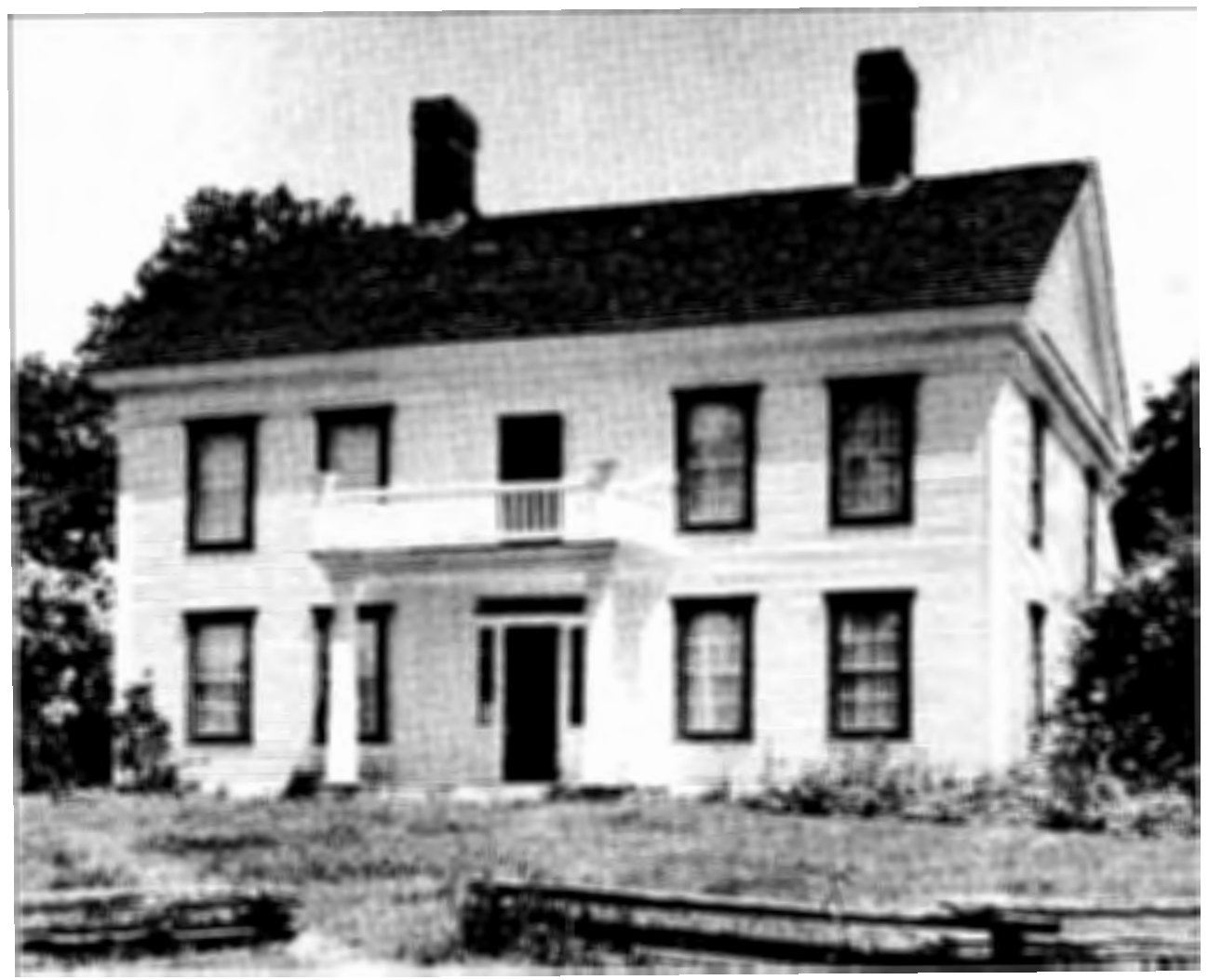

Figure 18. Bybee-Howel1 House, Sauvie Island, Oregon. Included in the 1934 HABS survey, now an Oregon Historical Society property.

Begun in 1933-1934 as a short time combined volunteer and Works Projects Administration funded effort to give employment to architects, HABS sent out teams of architects in almost every state to measure and document historic buildings. On the east coast these were colonial buildings; on the west coast, pioneer and mission buildings.

HABS was the inspiration of the Chief Architect of the National Park Service, Charles E. Peterson, who had worked on restorations at Colonial Williamsburg and at the Moore 
House, Yorktown, Virginia.66 Peterson devised a program whereby the Park Service, Library of Congress, and the American Institute of Architects would cooperatively implement the recruitment of recording team members, plan the documentation effort, and provide for its archival collection and publication. When completed in 1940, after several phases, 6,389 structures were documented, with about one-half recorded by measured drawings, drawings very similar to those in the White Pine Monographs.67 The HABS documentation effort and its publicity combined with the American Colonial Revival Style movement of the 1920 s to make that style even better known and popular than it had been before and insured that it would be the preferred architectural style for small homes throughout the Depression and the postwar years.

\section{HOUSING RESEARCH IS SUPPORTED}

The National Housing Act and FHA stimulated research into home planning, building technology and methods, and the development of new building materials. Government support for this research was paralleled by private industrial

${ }^{66}$ Charles E. Peterson, The Moore House, (Washington: National Parks \& Conservation Assoc., 1981).

67National Park Service, Historic American Buildings Survey (Washington: Government Printing Office, 1941). Copies of the original survey reports, photographs, and measured drawings reside in both the Oregon State Library and Oregon Historical Society archives. Also; Potter, A History of HABS. 
research to develop new building products and systems or for adapting previously developed products to new uses. FHA did not do research itself, but marshalled the resources of existing federal agencies and commissioned research by-other public and private institutions. Building industry private research was a continuation of its work before the Depression, but with a special emphasis on products which showed promise for lowering building costs. The Depression also made building materials manufacturers look for ways to increase their efficiency by more industrialization and better waste reduction or recovery, with the result that many new products were introduced along with stronger marketing programs.

By 1940, the National Bureau of Standards, U.S. Department of Commerce, had done the research and published reports on over 27 studies in the "Building Materials and Structures Report" series, many of which were on innovative products and systems, such as fiber building boards, plywood panel construction, and patented industrialized building systems and prefabrication. 68

68National Bureau of Standards, Building Materials and Structures Report, various subjects and authors (Washington: Government Printing Office, 1940). The copies available are: Cyrus C. Fishburn and Perry H. Peterson, Effect of Heating and Cooling on the Permeability of Masonry Walls, Report BMS41, January 1940; and, J. J. Tregoning, K. A. Milliken, A. Hockman, and D. W. Kessler, Plastic Calking Materials, Report BMS33, January 1940. These are technical and scientific reports which may be used as a basis for subsequent FHA standards or incorporated in building codes: In some cased, they represent studies requested by a 
The Forest Products Laboratory (FPL) of the U.S.

Forest Service, Department of Agriculture, was established in 1910 in Madison, Wisconsin, in response to a growing recognition of the need to conserve and better utilize. forest resources. FPL pioneered in the testing and development of 1 umber use and engineering standards. In 1935 it published the first edition of the Wood Handbook, a reference document on the most commonly used soft and hard woods in the United States describing their appearance, finishing, and engineering qualities for all uses from furniture to buildings. Copies of the Wood Handbook are still issued in revised editions.69 FPL often worked in cooperation with manufacturers and trade associations on research and development. Government research applicable to the uses of wood products in home building began in the 1930 s and was greatly stimulated by the war effort of the 1940s and the critical housing shortages of the 1950s.

Industry research was not new in the 1930 s but was a continuation of previous work given new importance by the government support for home building. Weyerhaeuser Timber Company and its subsidiaries, as a major timberland owner

manufacturer so as to gain acceptance for his product or system.

69Forest Products Laboratory, Age of Wood: Progress Through Wood Research, 75th Anniversary booklet (Madison: FPL, 1985). Forest Products Laboratory, Wood Handbook: Wood as an Engineering Material, Agriculture Handbook No. 72, rev. Aug. 1972 (Washington: Government Printing Office). There is a later edition and $I$ also have the 1955 edition. 
and timber products producer had at an early date seen the necessity of conducting product development research and for instituting innovative marketing programs in order to maintain its growth and position. By the 1930s, Weyerhaeuser had developed building insulation products, fiberboards from wood waste and "trash trees," acoustic tile, and the 1927-28 initiated "4-Square Lumber" marketing program.70 "4-Square" was immediately adapted to the FHA home modernization program in 1934, actively promoted by Weyerhaeuser salesmen and its dealers, and was expanded to the "4-Square Home Building Service" as soon as the new home insurance program, Title II, was organized; the 4-Square Home Service was terminated by World War-II. Advertisements of Weyerhaeuser "4-Square" lumber products and its other building materials appeared prominently in all of the leading popular and building journals in the 1930s. Weyerhaeuser expanded its previous extensions into providing building designs and plans to owners and to home builders through direct mail and from its lumber products distributors.71 In 1935 and 1937 , the company cooperated with the Douglas Fir Plywood Association and National Bureau of Standards in the first Commercial Standard for Douglas Fir P1ywood, CS45-33. Throughout

${ }^{70} \mathrm{~T}$. L. O'Gara, letters, Weyerhaeuser Archives, Tacoma, Washington.

${ }^{71}$ Ralph W. Hidy, Frank Ernest Hill, and Allan Nevins, Timber and Men: The Weyerhaeuser Story (N.Y: The Macmilian Co., 1963), pp. 434-450. 
the Depression, Weyerhaeuser, other companies and their business association, the National Lumber Manufacturers Association, energetically promoted home building, the use of lumber and lumber by-products, and offered help to the government and to the home builders and buyers.

\section{INDUSTRIALIZED HOUSING SOLUTIONS}

The term mass production is used to describe the modern method by which great quantities of a single standardized commodity are manufactured. Mass production is not merely quantity production...nor is it merely machine production. Mass Production is the focusing upon a manufacturing project of the principles of power, accuracy, economy, system, continuity and speed. The interpretation of these principles, through studies of operation and machine development and their coordination, is the conspicuous task of management. And the normal result is a productive organization that delivers in quantities a useful commodity of standard material, workmanship and design at a minimum cost...72

Weyerhaeuser experimented with various prefabricated house programs. An "Experimental House" was built in 1932 on Capitol Hill, Seattle, and one in the Madison Park Area of Chicago one year later for the Century of Progress Exposition. The "Tim-Bo-Lock" system was, "The lumberman's answer to the mounting demand for prefabricated homes.", and was one of many experimental prefabrication systems which were tried but went nowhere. Throughout the Depression,

72 Herbert Gilbert, The Dream of the Factory Made House (Baltimore: The Johns Hopkins Press, 1978), p. 1, quoting Henry Ford as given in Richard Bender's A Crack' in the Rear-View Mirror. 


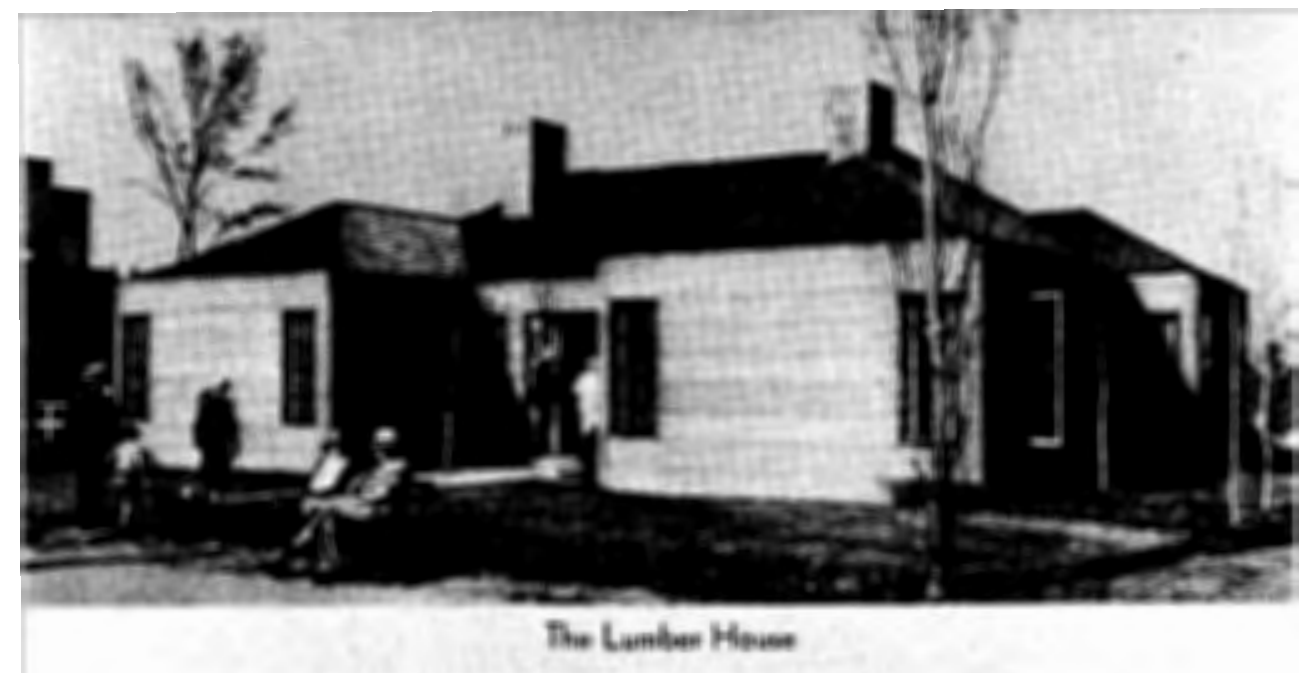

Figure 19. The Weyerhaeuser "Lumber House" displayed at the Chicago Exposition. One of these houses remains in Seattle. Official Pictures, 1933.

Weyerhaeuser companies sought to design, manufacture, and market a successful prefabricated house; they were interrupted by the war, but continued to promote both prefabricated houses and conventional "stick-built" houses afterwards.73 The prefabrication and industrialized building attempts in the Depression years were a continuation of earlier efforts. Various ways to mass produce lowcost housing construction seemed to offer the only means of meeting the need for homes at affordable prices.

There is no lack of a history of prefabricated house

73Weyerhaeuser Timber Company Archives, Tacoma, Washington. Box 5, Correspondence on Experimental House for R. C. Reamer, Seattle, Washington. Box 6, Information on Tim-Bo-Lock System, Plunkett-Webster Lumber Company. 
systems, it goes back at least to the late 18 th century. Homes and other buildings were prefabricated in England for erection in Australia and South Africa in 1787 and then in 1840. A house for erection in Grenada was prefabricated in Portsmouth, New Hampshire, in 1772. Cast-iron building systems began with Joseph Paxton's 1851 Crystal Palace and continued into other buildings, James Bogardus and Daniel D. Badger's cast iron buildings in 1856 and 1865, and Gustave Eiffel's church in 1892.74 By 1920, the English and Germans had tried various types of prefabrication of homes in an attempt to solve their housing shortages.

Prefabricated (pre-cut) homes were marketed by Aladdin, Sears-Roebuck \& Company, and many other national and local companies in the 1910s and 1920s. Frank Lloyd Wright, beginning with his pre-cut models for American Homes in Wisconsin, pursued the idea into the 1930 s with his Usonian homes.75 These house building systems and their promises of economy and dependable quality were well known.

74 Herbert, Pioneers of Prefabrication, pp: 4-8. Adolph K. Placzek, ed., The Origins of Cast Iron Architecture, (N.Y: Da Capo Press, 1970). International Council on Monuments and Sites, Eisen Architektur, international colloquium in September 1978, Bad Ems (Mainz: ICOMOS Deutches Nationalkomitee, 1979).

${ }^{75}$ The Aladdin Company, Aladdin Homes "Built in a Day", catalog (Bay City, Mich: The Aladdin Company, 1920). Katharine Cole Stevenson and $H$. Ward Jandle, Houses By Mail, (Washington: Preservation Press, 1986). The National Trust for Historic Preservation, Pope-Leighey House, information brochure and reprints of measured drawings (Washington: The Preservation Press, 1978). 
The Aladdin and Sears homes enjoyed a considerable measure of success in the early years before the Depression. However, the successful prefabricated house failed to meet the expectations of home buyers in the 1930s, and each model and trial was a one-shot effort. American tastes rejected the uniformity of industrialized houses. Aladdin and Sears' houses were successful because they had been limited to traditional styles and types of houses, conventionally built on the site, but using factory pre-cutting methods and quantity purchasing economies, not true prefabrication and factory building.

An Aladdin company plant was located in Portland. There also were competing local and west coast pre-cut home manufacturers. Fenner Manufacturing Company's "Homes of Distinction" showed 21 models in the 1924 brochure and claimed that it had shipped thousands of homes throughout the west and to Alaska, New Zealand, South America, and Japan. Portland had several prefabricated or pre-cut house manufacturers which sold primarily to the local market. It is unfortunate that little or no research has been done on these homes and none of them are identified in the Portland's historic landmark inventory. 76

76 Readimade Sectional Houses, catalog (Portland: Redimade Building Company, 1920). 


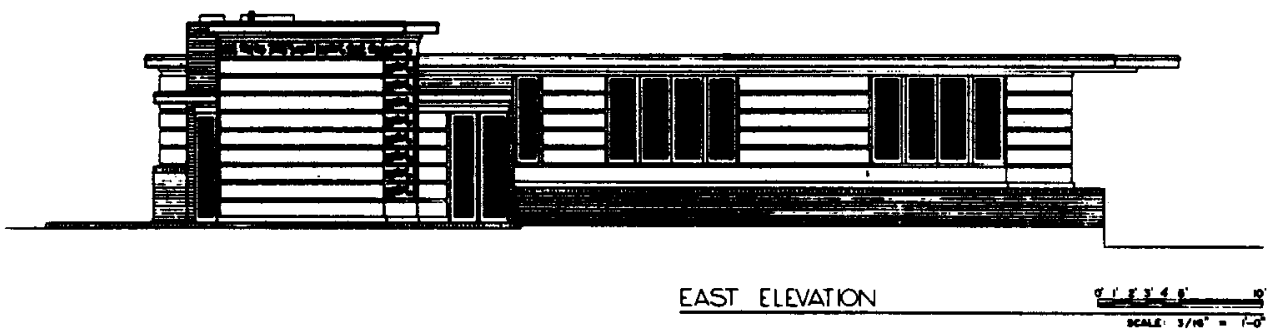

Figure 20. Usonian Pope-Leighey House, Woodlawn, Virginia. National Trust measured drawings.

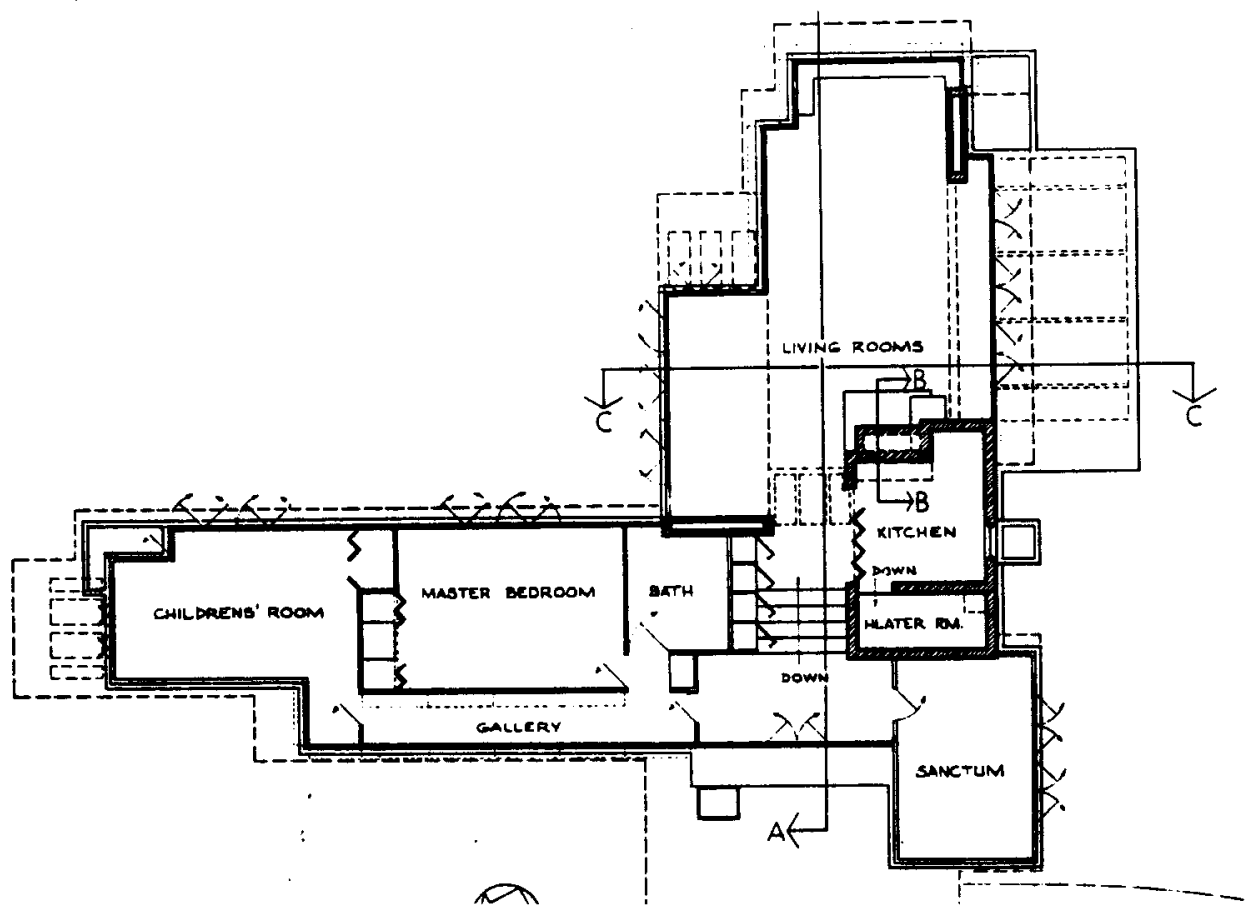

Figure 21. Frank Lloyd Wright designed Usonian house at Woodlawn: The house is delightful, but its construction is terribly impractical. These "prefabricated 1ow-cost" houses had to be custom built on site and were not low-cost. 


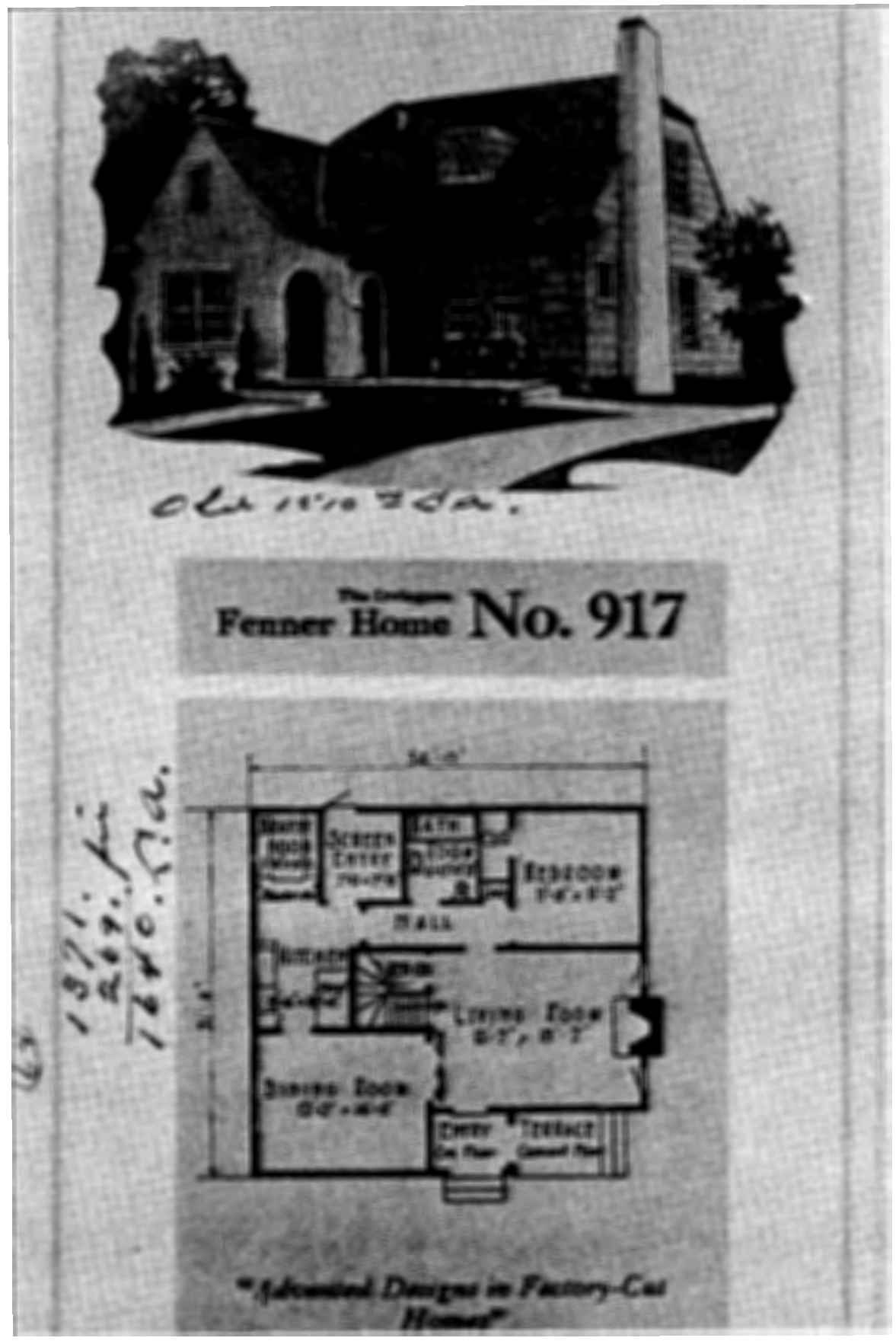

Figure 22. Fenner pre-cut homes.

Research and development into industrialized home building products and methods did produce benefits which saw limited use before World War-II. Light weight roof trusses 


\section{REDIMADE SECTIONAL HOUSES}

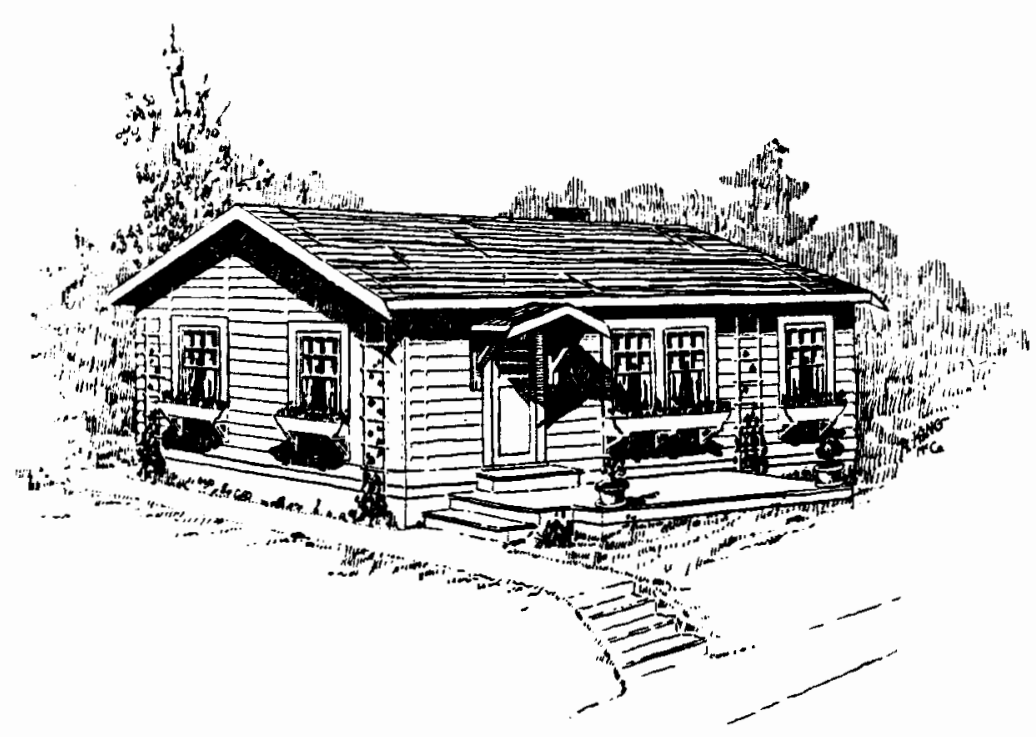

\section{WINDSOR MODEL}

PLA N N O . 9

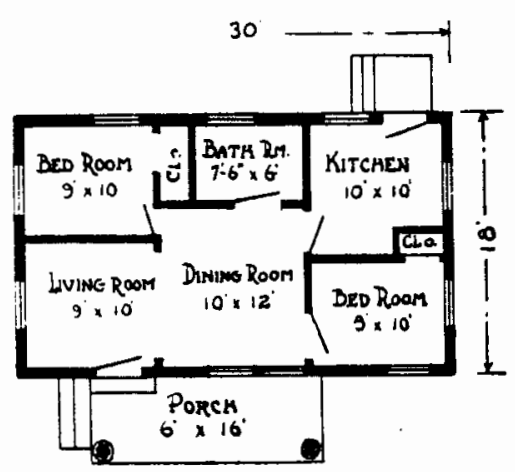
Combination Living and Dining Room has three full windows.
Each Bed Room has two full windows.
Kitchen has two half win- dows and a 4-light sash door.

Bath Room has a half window.

\section{Figure 23. Readimade Homes.}

combining rafters with ceiling joists were pre-fabricated, various wall panel systems were experimented with, stressedskin panel construction was proven, exterior use plywood 
panels were developed, glue-laminated timbers developed, and many new wall board and interior finish materials began to be manufactured and saw limited use before the war came. However; most FHA insured houses built before 1942 were conventional in design, construction, and finishes, reflecting both the resistance of the home building industry and home buyers to accept changes and of FHA to accept and insure mortgages on homes with unusual building innovations.

\section{POPULAR CULTURE AND THE AMERICAN DREAM OF HOME}

In his book, The American Dream in the Great Depression, 77 Charles $R$. Hearn discusses the history and nature of the American dream and shows how it persevered and transcended the realities of the Depression. In popular literature, magazines and novels, the rags-to-riches theme persisted; a tragedy occurred when the protagonist failed in the attempt to succeed. Hearn states in his introduction: "Probably no idea has had a greater appeal to the American imagination than the American dream of material success." He concludes that the conflict between Depression reality and the dream produced complex, confused, and contradictory effects in the 1930s' artists and the public. Ingrained optimism coincided with disillusion. People sought hope and the promises of reaching the dream at the same time they dealt with their 
inability to achieve any measure of prosperity and security.

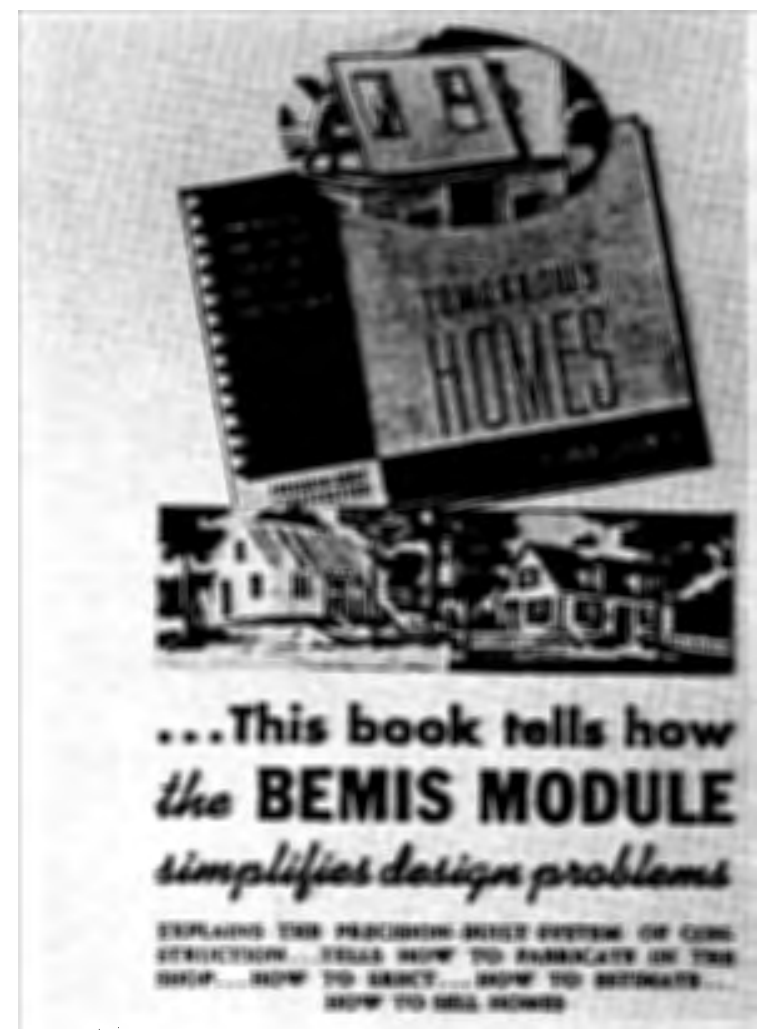

Figure 24. Advertisement for a modular pane1 building material. Note the use book offered. From Architectural Forum, November, 1939.

Good housing, one's own home, continued to be presented in stories, songs, movies, in government programs, and in the newspapers and periodicals despite the fact that most families who needed housing remained unable to purchase it. New houses were promoted by industry and government as desirable for improving the welfare and stability of families and because the building of the homes would reemploy the home building trades and workers in the related industries. 


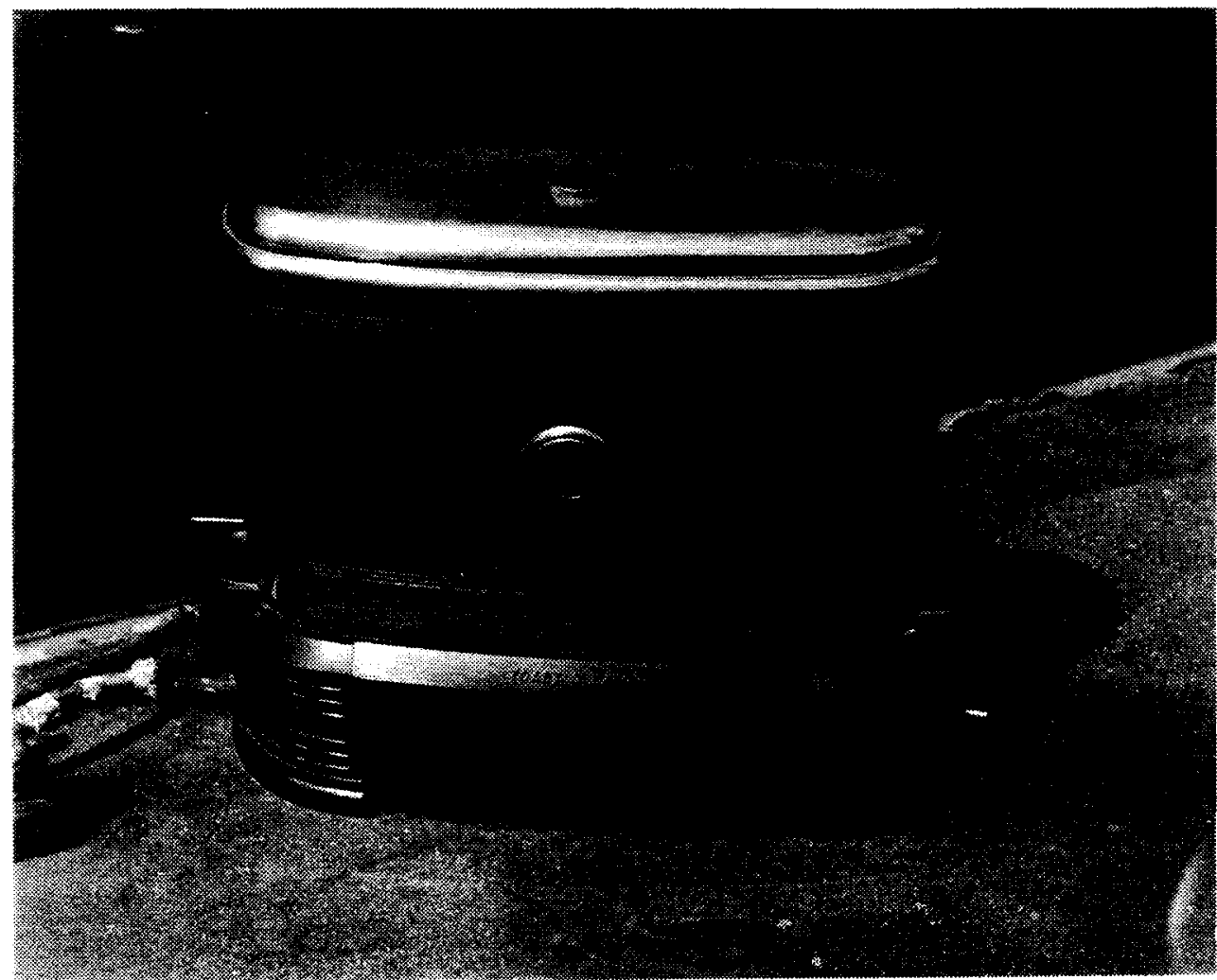

Figure 25. A Streamlined toaster. Symbol of Depression modernity, c.1936.

Three worlds fairs in the United States during the Depression exhibited American hopes for a better tomorrow and the ideal low-cost house that would be built. The Chicago Century of Progress Exposition in 1933-34, the bottom of the Depression, presented a vision of an industrialized streamlined modern America, a hope for the future in the shape of aerodynamic toasters. There were some who did not accept the vision, and, with uncommon foresight, saw in the exhibits a future of urban sprawl and automobile congestion:

So far as I can see, the only future they envisage (the fair's viewers) as they plod wearily about the 
grounds and uncomplainingly pay nickel after nickel for entry to the lavatories, is one very like their past. More automobiles, with better, gadgets, television added to their radios...78.

The Century of Progress Exposition kicked off the public presentation of modern industrial design. Designers Norman Bel Geddes, Raymond Loewy, Henry Dreyfuss, and Walter Dorwin Teague fashioned streamlined envelopes for everything from vacuum cleaners to trains.79 Several model houses were featured, most importantly, George Fred Keck's "House of Tomorrow" and his "Crystal House." Along side its modern and streamlined companions, Weyerhaeuser Company's prefabricated house appears very conventional. The Chicago exposition began a love affair with modern industrial design which climaxed in the New York Worlds Fair, "The World of Tomorrow," in 1939.

Compared to the Chicago exposition, the New York fair's housing exhibits were more restrained. "The All Gas Home of Tomorrow" is a modest one story Modern Classic Revival design with much of the same style influence found in contemporary public buildings; the Oregon State Capitol Building (1938) is one of these. A "Town of Tomorrow" was built just outside the fair's gate showing model homes in a

78 Bruce Bliven, "A Century of Treadmi11: A Few Funeral Flaws from the Chicago Fair," The New Republic, Vol. LXXVI, 15 Nov. 1933.

${ }^{79}$ Donald J. Bush, The Streamlined Decade (N.Y: George Braziller, 1975). 


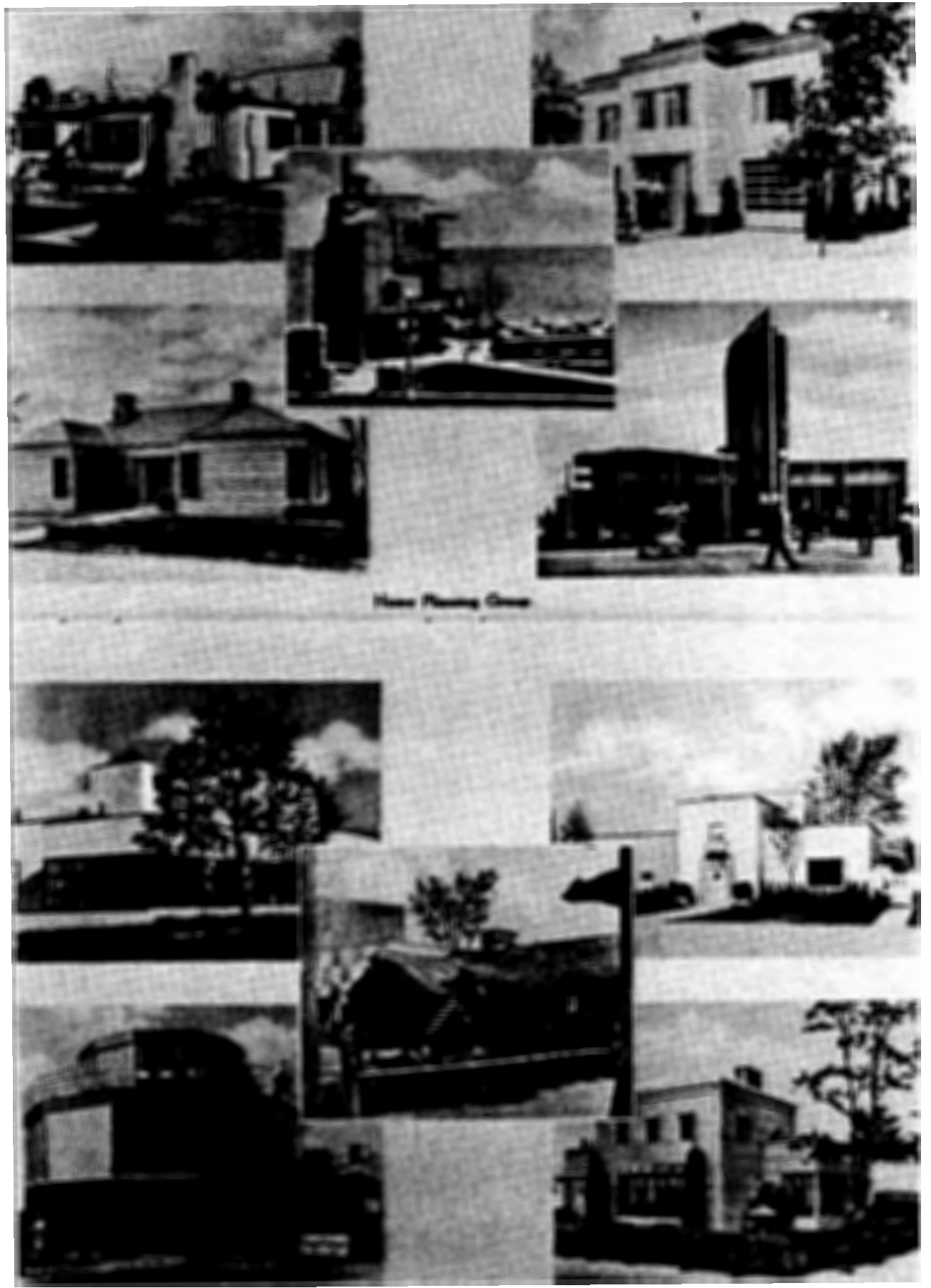

Figure 26. Houses of Tomorrow, Chicago Exposition, 1933-34. The Weyerhaeuser "Lumber House" is second on left from top. Souvenir Book-1934, World's Fair Chicago (Chicago: Court Teich \& Co., 1934). 


\section{$3.40^{2}+2$}

\section{0}
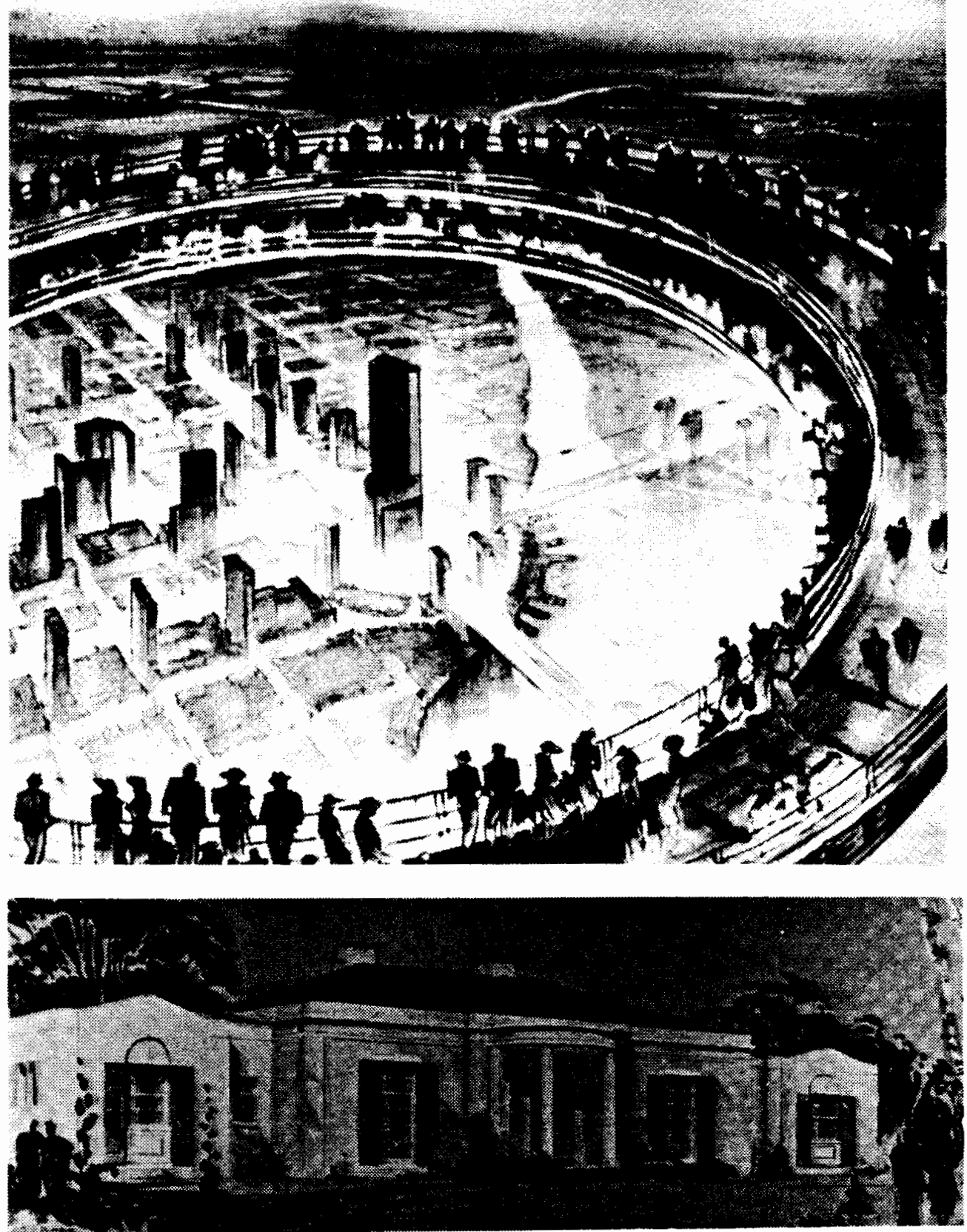

Figure 27. Official views of the New York Worlds Fair, 1939. "Democracity" and the "All Gas Home" of tomorrow. From Official Guide Book, 1939. 
variety of styles, from minimal to luxury in cost, and featuring the latest building materials.80 Newspaper, magazine, and newsreel coverage of the New York fair and its theme of progress was continuous throughout its run. In addition to the how-to-get-there and what-to-see stories, news media featured its local communities and how they were preparing for the new future; the events in Europe and Asia did not fit within the dream. Thus, Fortune magazine in July 1939 devoted its entire issue to New York City, its history, structure, and future. Mayor LaGuardia is pictured on one page with his streamlined Chrysler Airflow on the next. The articles tell about the city's immigrants, its vice, government, and show girls and the advertisements depict the progressive theme of new products for the hopeful tomorrow.

The corresponding Golden Gate Exposition (1939) in San Francisco also celebrated the future and progress, but adhered to a more traditional design theme, an architectural unity of Modern Mission Revival and Art Deco with little of the industrial design influence used in Chicago in 1933-34 and New York (1939). In their ways, each fair exerted a strong influence on public taste and its expectations for the dream home.

It was the motion picture which more than any other 
influence defined the American dream home. The magazine advertisements and illustrations showed details and plans and defined the ideal kitchen and bathroom. Newspaper articles and house feature pages offered local housing solutions. But the popular movie stars, their roles, and the sets for the movies took the house hungry public into ideal dream houses and presented illusions with which the movie goer identified.

Modernistic settings for the movies had their influence on popular taste. Streamlined furniture, accessories, and particularly the industrial areas of the home, the kitchen, bath, and laundry, showed the influences of both modern industrial design and to a limited extent International Modern. Hollywood movie sets created their own style, "Hollywood Modern," as extreme as both the life styles of the actors and actresses reported in the fan magazines and Sunday newspaper supplement sections and as the characters portrayed in front of the cameras. The pictures were complete, characters, dress, sets, transportation, a11. The Topper series of comedies represented the complete escape from Depression reality with characters who were extravagant and 1 ived extravagant "lives," their homes were ultra-modern, their car a super streamlined dream car to match.

It was, however, the depiction of more traditional style and living values, the more safe and secure, which won 
lasting popular allegiance. Leading in presenting the popular movie ideal life complete with the ideal home, The Andy Hardy series of films, beginning with A Family Affair in 1937 through fourteen sequels, ended with Andy as a young adult and war veteran after the war.81 Judge Hardy's home

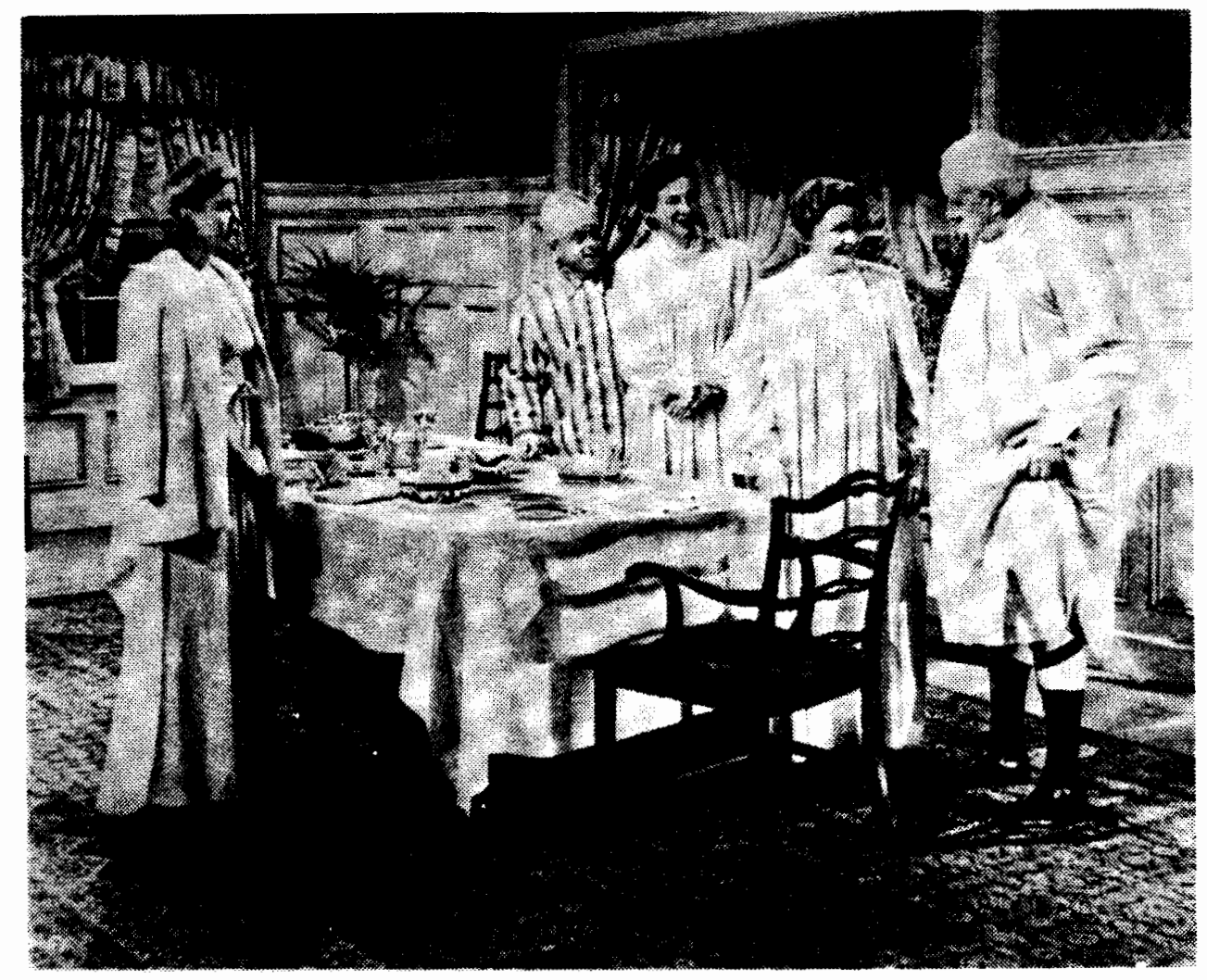

Figure 28. The Hardy Family in its traditionally styleddining room. From clipping collection of Central Library, Portland.

in the fictitious town of Carvel, Idaho, was the scene for the cinematic eavesdropping, a thoroughly conventional Classic or Colonial Revival Style house which in the movies seems to contain vast spaces and numberless rooms, a house

81 "Hardy Family on Set Again," The Oregonian, 14 July 1946, Sec. 3, p. 1 . 
which was as far beyond the means of most Depression movie goers as was "Tara" in Gone With the Wind. Mickey Rooney as Andy was the stereotypical teen age boy in an idealized family. Because of the Hardy series, Mickey soon became a number one box-office attraction and his films top moneymakers. The public remembered the scenes and the illusion and not the real life story of Mickey Rooney, very different from that of Andy Hardy.82 The illusion so met the needs of the Depression public that it wanted homes like that of the Hardy family. Traditional architectural styles for homes, particularly the Colonial Revival Style, became lastingly identified with the ideal American home.

\section{THE LUMBER INDUSTRY AND THE LOW-COST HOME}

The wood products industry had a primary interest in home building and became an eager participant in the FHA insured home mortgage program. The 1933 brochure published by the West Coast Lumbermen's Association showed four models of very small one-bedroom cottages designed by Washington state architects for $10 w$-cost construction. Western wood products were featured in these homes which were of conventional construction and traditional designs. The Lumbermen's Association expanded its participation in low-cost home development and promotion of home building with

${ }^{82}$ Arthur Marx, The Nine Lives of Mickey Rooney (N.Y: Stein \& Day, 1984), Pp. 56-63, 123. 
additional plan services and by doing extensive advertising. The Weyerhaeuser Company issued its Home Building Plan Book in 1937 and again in 1939, 1940, and after the war.

Weyerhaeuser developed and promoted its prefabricated house models and had sought and received FHA approval of its sys tem.

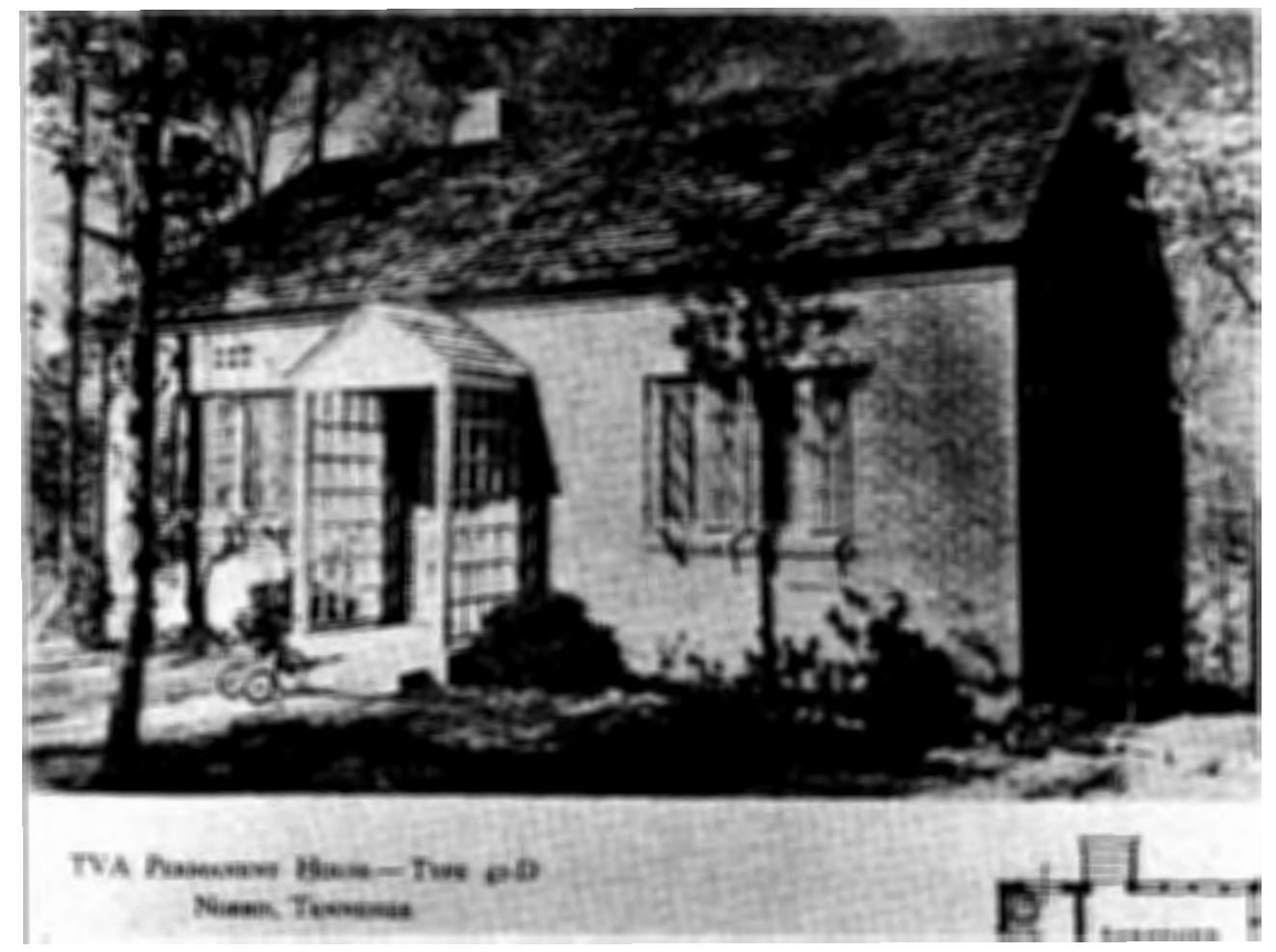

Figure 29. Traditional style TVA house, Norris, Tennessee. From The Book of Houses.

The other building industry manufacturers and suppliers all promoted their products and services actively during the Depression and emphasized the ideal home. As one writer described a proposed small house design, "It was as pretty as a four color bathroom advertisement." But, throughout the Depression, few houses were actually being 
built, there were dreams but few new homes for all those who wanted them.

GOVERNMENT'S INFLUENCE ON THE DREAM OF LOW-COST HOMES

The federal government had actively promoted low-cost homes beginning with the Tennessee Valley Authority (TVA) project in 1933. As a region wide umbrella organizational concept, low-cost and prefabricated housing was built for the project workers and for the poor families being resettled from the reservoir basins. Other new housing and resettlement programs by various agencies dominated the government housing activities. The U.S. Resettlement Administration's many examples of both new towns and model home developments established a variety of patterns, from the examples of modern Greenbelt, Maryland, to Colonial Revival Longview Homesteads, Longview, Washington.

Greenbelt, Maryland, was a new town planned to be the realization of new social and architectural designs embodying many of the theories developed in England and Germany. This small city development was to provide clean modern homes for low income families near Washington, D.C. Greenbelt's influence on architectural training and practice lasted for the next thirty years as architects and students reviewed its planning, its separation of pedestrian and auto traffic, the orientation of the housing unit fronts toward communal space, and the incorporation of community facili- 

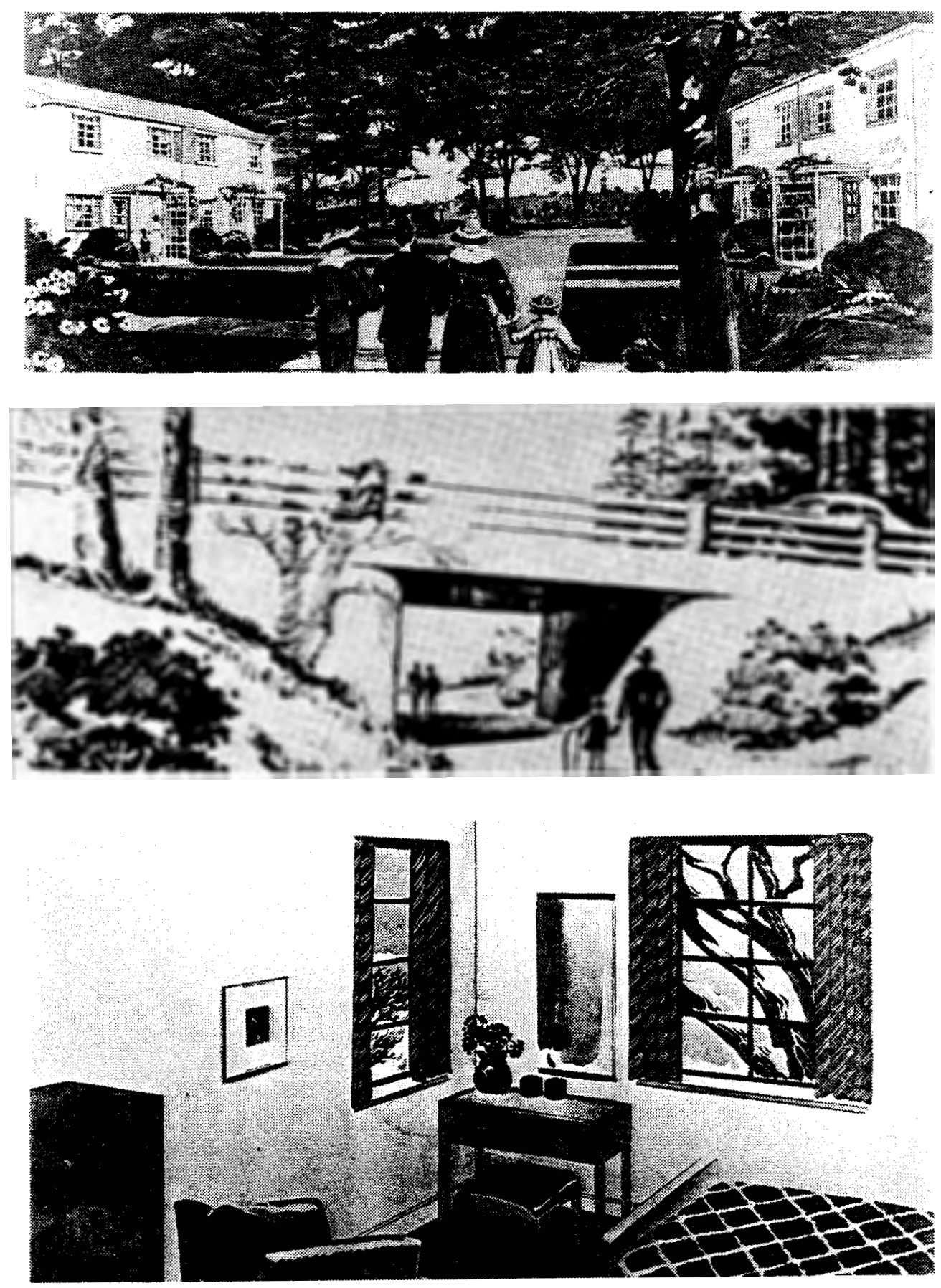

Figure 30. Greenbelt, Maryland, 1936. Views from Library of Congress collection. Architect's renderings: townhouse units, pedestrian underpass, and typical bedroom interior. 

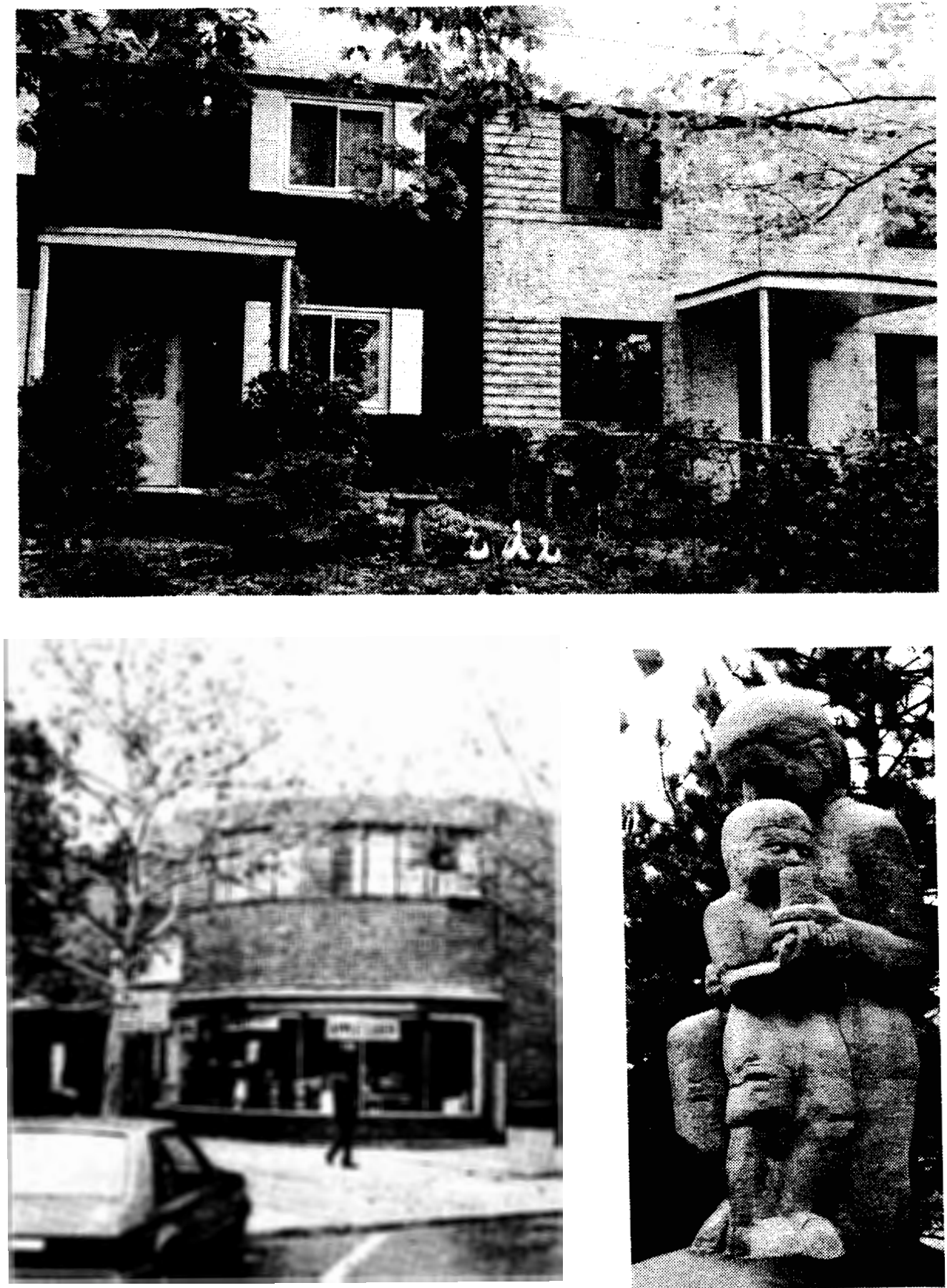

Figure 31. Recent views of Greenbelt, Maryland. The shopping center and pedestrian ways are almost deserted, and the houses have been "fixedup" by the owners. The ambience seems dejected, like a lost dream. A restoration plan is now beginning. 
ties, many of which were co-op organizations. Greenbelt remains today as a somewhat changed suburban community among many others. Its co-operatives are no longer. The clean modern styling of its apartment and rowhouse units often have had Colonial Style trim additions. And its separated pedestrian ways are unused, because everyone drives a car even to the nearby school or shopping/community center (the theater is closed).

Longview Homesteads was a much smaller scale housing development built between 1934 and 1935 on land immediately on the north edge of the relatively new planned city of Longview, Washington. The Longview Company land was designated Columbia Valley Gardens and had been partially developed and built upon in the 1920 s as an area of substantial sawmill workers' homes with large semi-agricultural lots or farmsteads. Longview Homesteads consisted of 60 new homes on approximately two acre lots. The Colonial Revival Style homes were of three sizes, four, five, and six rooms each, one to one and one-half story. Designed by Longview architect Ray $V$. Weatherby, the houses soon were transferred to private ownership and management and are all now private homes. They are remarkable in remaining substantially 


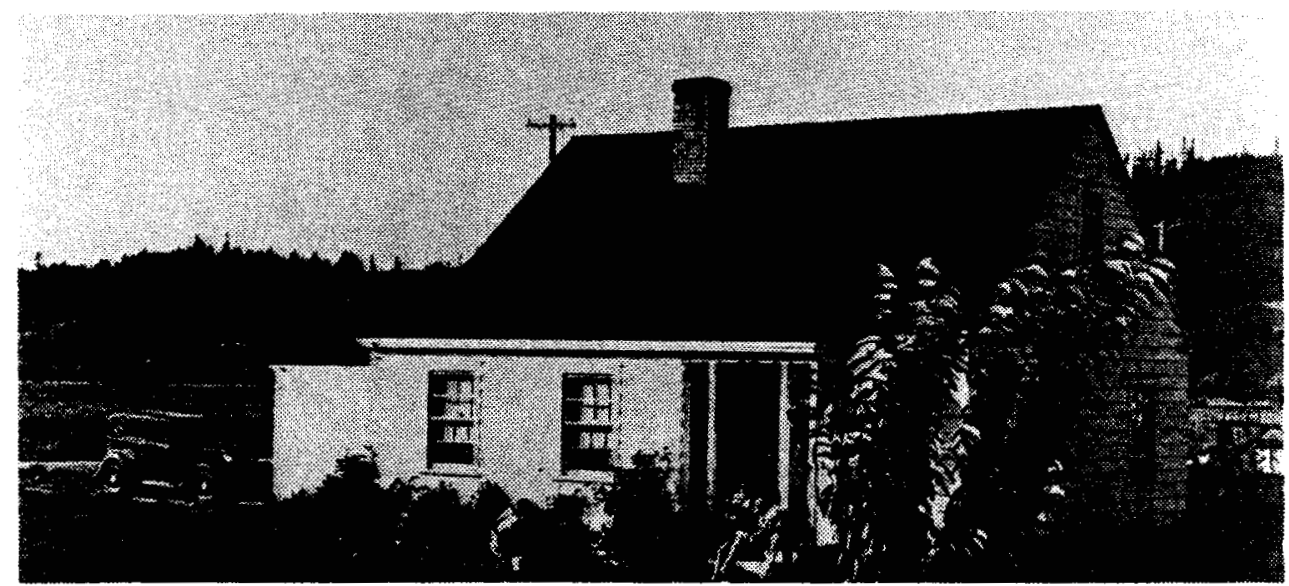

Figure 32. Longview Homesteads home, 1939. Dorothea Lange and Arthur Rothstein photos from Library of Congress collection.

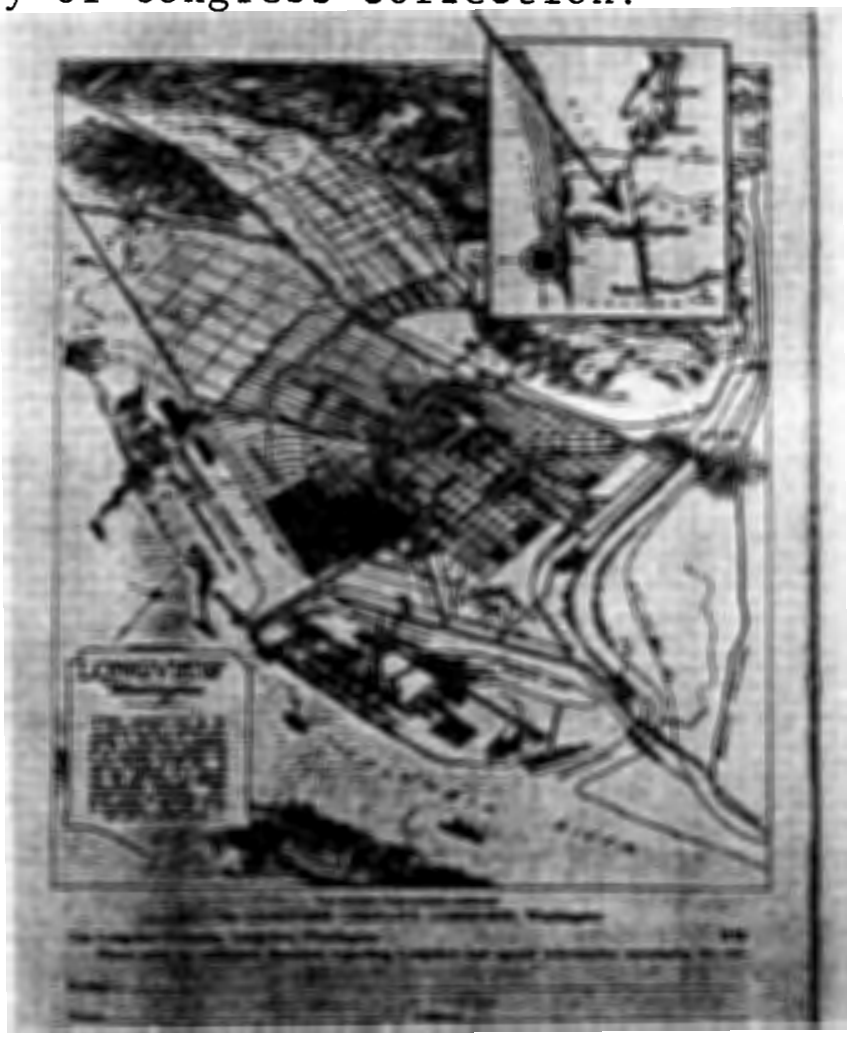

Figure 33. Longview Homesteads' site map. Longview Library collection. 


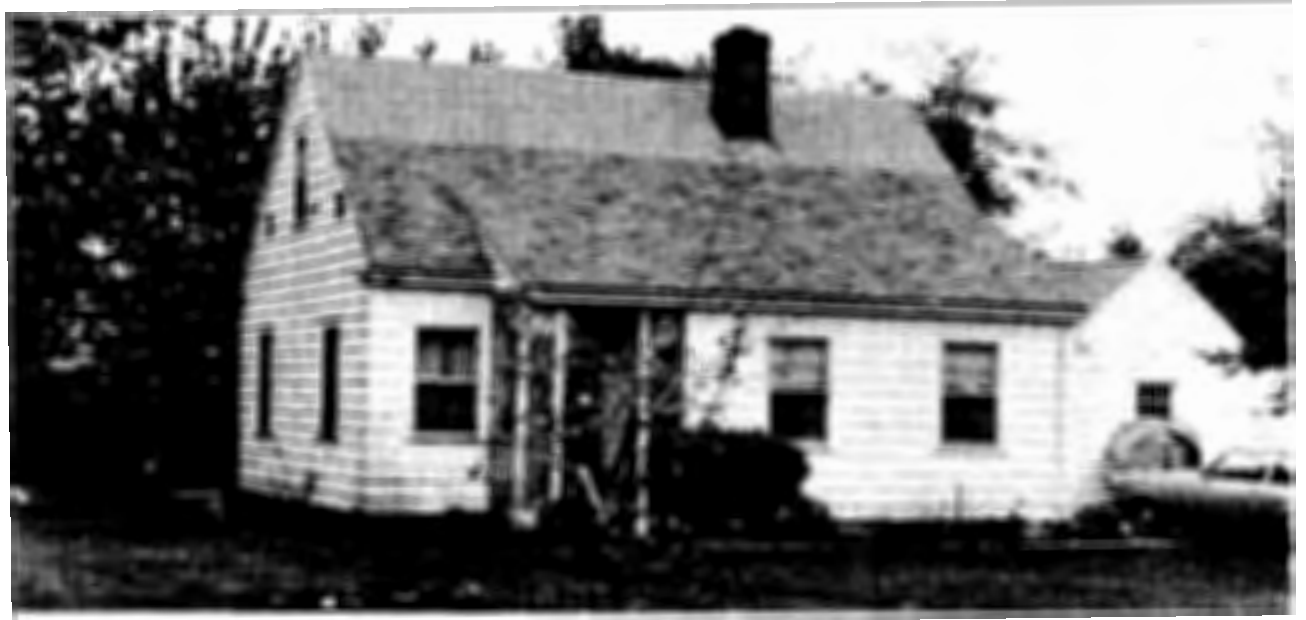

Figure 34. Longview Homesteads, 1986. Views of houses now privately owned.

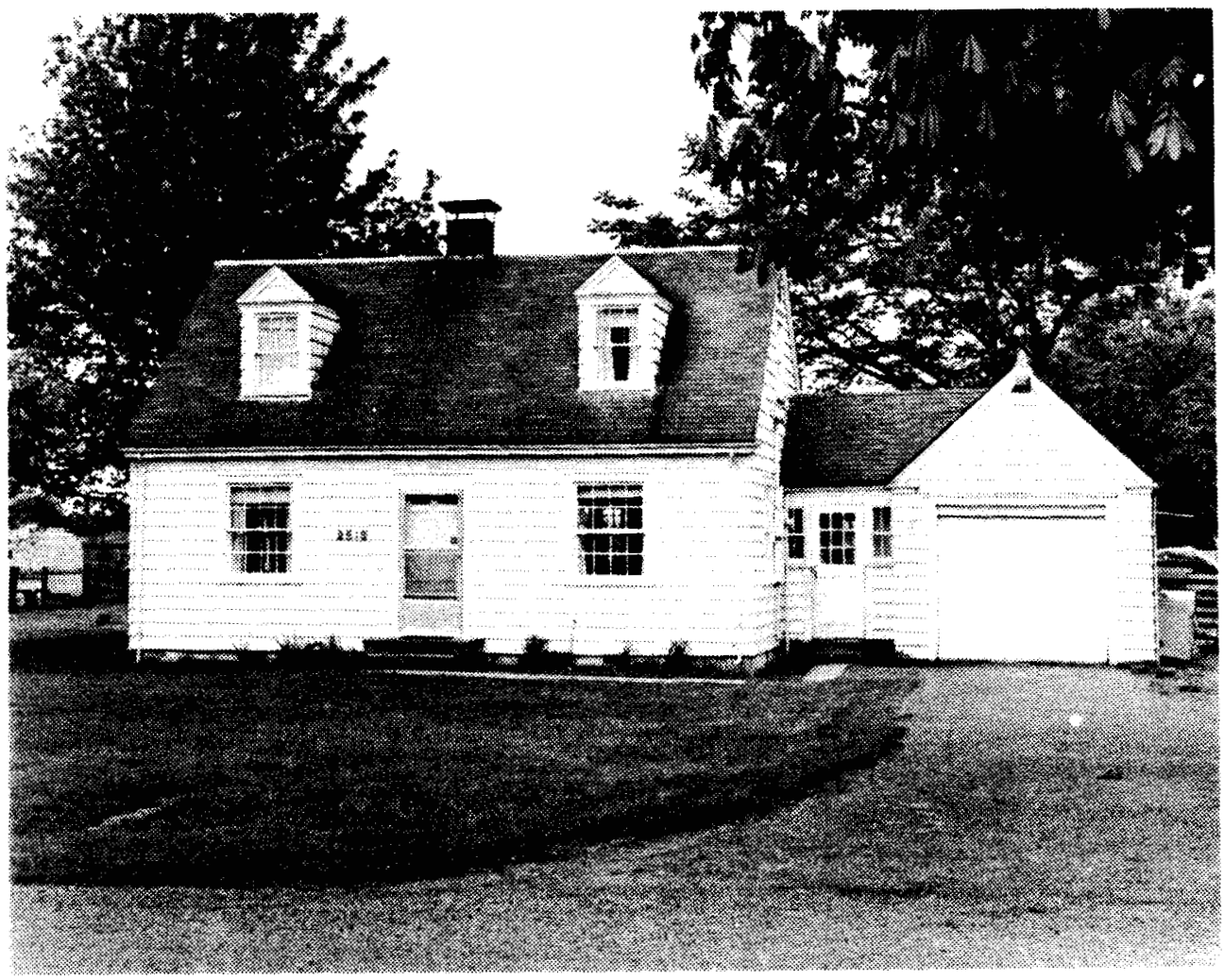

Figure 35. Longview Homesteads, 1986. Many of the original homes are remarkabiy unchanged except for new paint and smaller lots. 
complete as originally built, all are in generally excellent condition, and many appear unchanged from their 1935 condition. 83

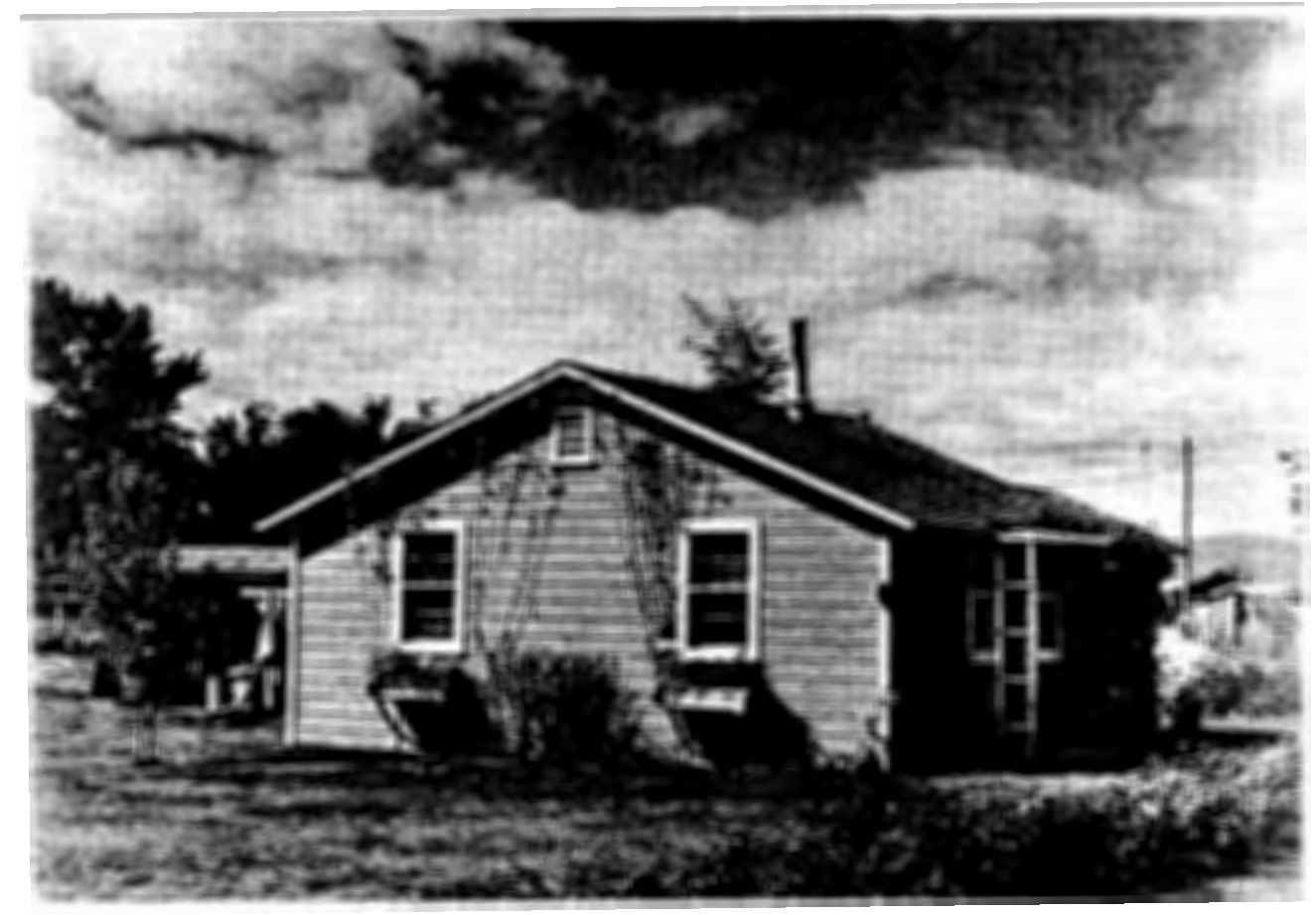

Figure 36. View of FSA migrant labor camp housing, Yakima, Washington, 1941. Library of Congress collection photo.

Other examples exist of Resettlement Administration and other agencies' Depression homes which illustrate how the government was involved in small home building. In addition to the earlier TVA housing, the Corps of Engineers built Colonial Revival style housing and community facili-

83 John A. McClelland, Jr., R. A. Long's Planned City: The Story of Longview, (Longview: Longview Publishing Company, 1976), Pp. 94-99. The initial information on Longview Homesteads was found in the Library of Congress's collection of Resettlement Administration photographs. Other information is in the library files of the Longview Daily News and the Longview Public Library's Longview Room. 


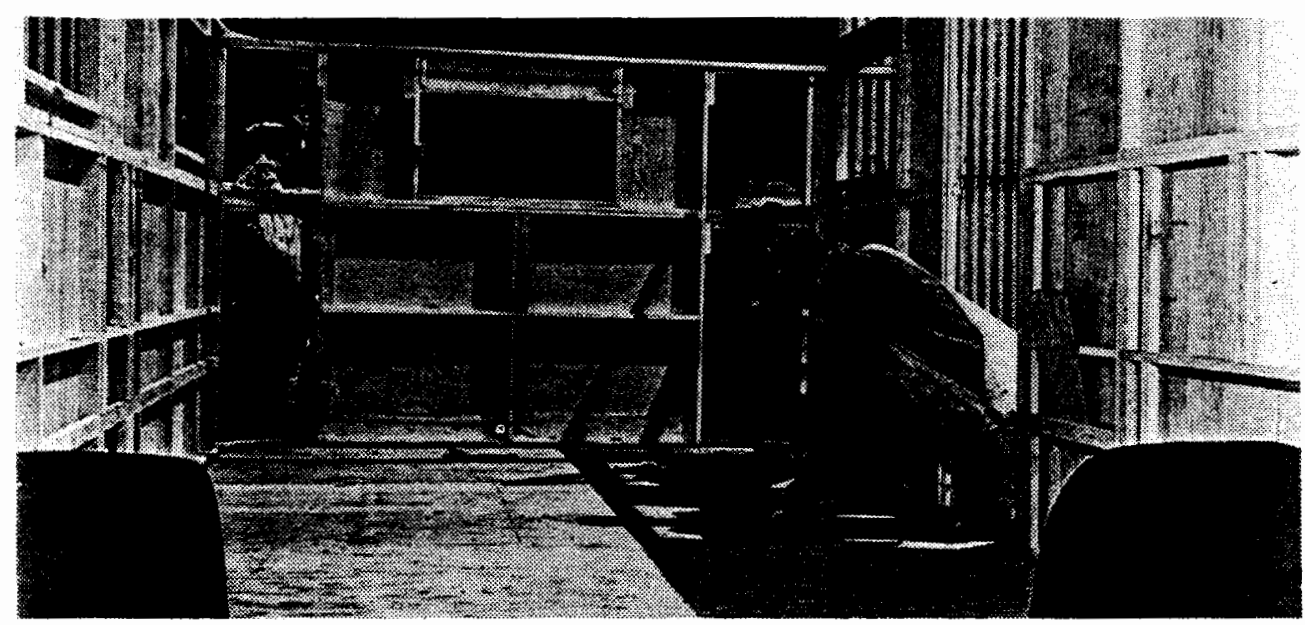

Figure 37. Defense housing trailer building in Los Angeles, 1942. Library of Congress collection, FSA.

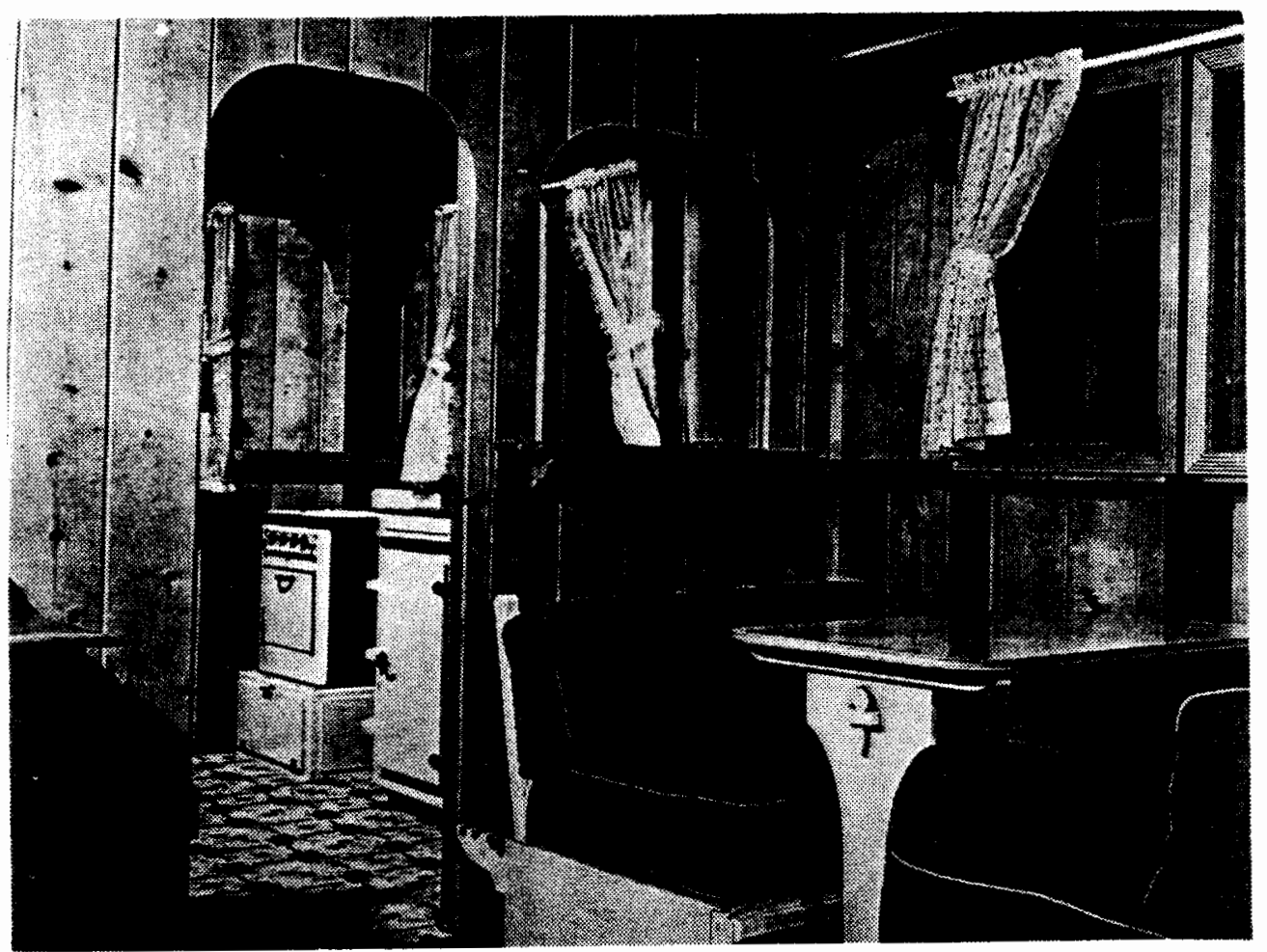

Figure 38. War housing trailer home interior. An early experiment in prefabrication. Westcraft Homes, Los Angeles, 1942. Library of Congress collection, FSA. 
ties for Bonneville Dam on the Columbia River, Oregon; however, the homes have been replaced.

An apparently less successful Resettlement Administration project was the one at Jersey Homesteads, New Jersey. According to the Saturday Evening Post article, "Four Million Dollar Village," cooperative housing was built for 100 garment worker families with poor results---and especially the taint of Socialism!84 Toward the end of the 1930s, the Farm Security Administration, succeeding the Resettlement Administration, continued the building programs with projects 1 ike a 1941 migrant farm worker housing near Yakima, eventually branching into mobile home projects as al1 government housing programs became merged into defense housing. 85

HOUSING INDUSTRY ORGANIZATION AT DEPRESSION'S END

As the Depression entered the 1940 s and the United States began its mobilization for World War-II, the home building industry began to organize a support structure for better preparing home builders and developers to compete successfully and to build efficiently, to coordinate

$84 \mathrm{Ra} 1 \mathrm{ph}$ F. Armstrong, "Four Million Dollar Village," The Saturday Evening Post, 2 May 1938, pp. 5-7, 34, 36, 38-9.

85

Henry J. Aaron, Shelter and Subsidies (Washington: The Brookings Inst., 1972). The Farm Security Administration homes programs peaked in 1937: They emphasized rural rehabilitation and cooperatives. The FSA program was superceded by the Farm Home Administration in 1946 . 
marketing efforts to buyers, and to lobby for housing legislation.

The National Association of Home Builders (NAHB) was founded in 1941 , but was preceded by smaller related organizations. For three years, the National Home Builders Bureau, Inc., New York, had been promoting small homes, publishing the Small Homes Year Book of plans. In the same year as the Builders Bureau's "Great American Home Show" in New York City and the founding of the NAHB, the Portland Home Builders Association (PHBA) was formed (changed in 1968 to the Home Builders Association of Metropolitan Portland (HBAMP). A support network of government, builders, and building material manufacturers was being formed which would combine to house defense workers during the war and then to commence the great postwar building boom.

The Small Homes Year Book of the National Home Builders, Inc. home show for 1941 has a profile of the average home buyer targeted by the builders under the FHA program. Following a one page article banner headlined, "But the Mortgage Villain is Dead!", there is a feature on financing new homes under FHA, "A New Home for the Robinson Family," representing a typical young middle class couple able to purchase a new builders' home. The Robinsons have no children, live in a rented apartment, and are paying $\$ 50.00$ monthly rent. Mr. Robinson is "...a technician in the engineering department of a tool company." His annual 


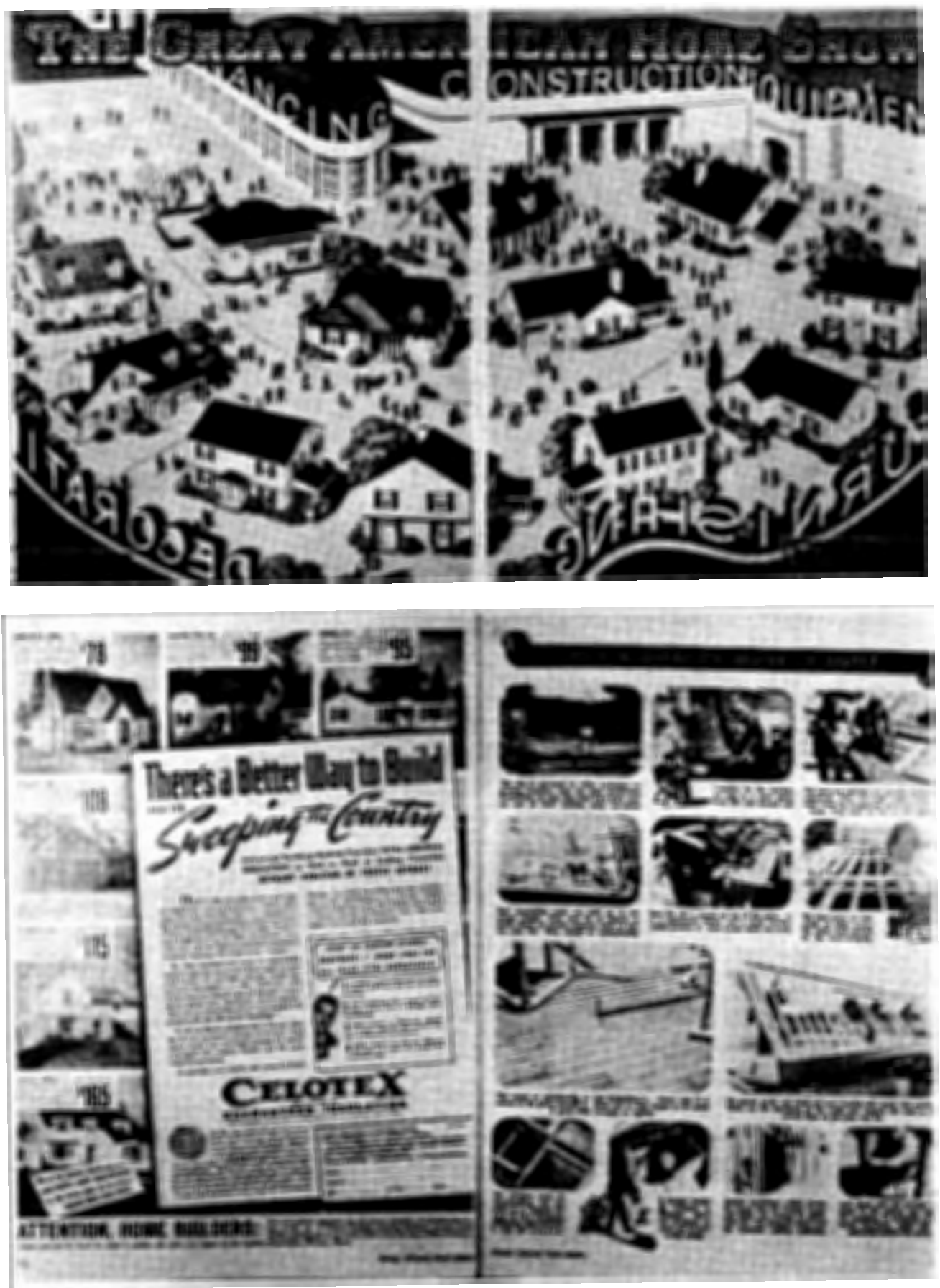

Figure 39. Illustrations from the 1941 Small Homes Yearbook by the National Home Builders, Inc. The catalog for their home show. 
salary or wage is about $\$ 2,500.00$ a year. They have managed to save $\$ 550.00$ towards a home building fund and have purchased a lot in a "we11 located suburban development" for another $\$ 600.00$. They decide to build a house on their lot

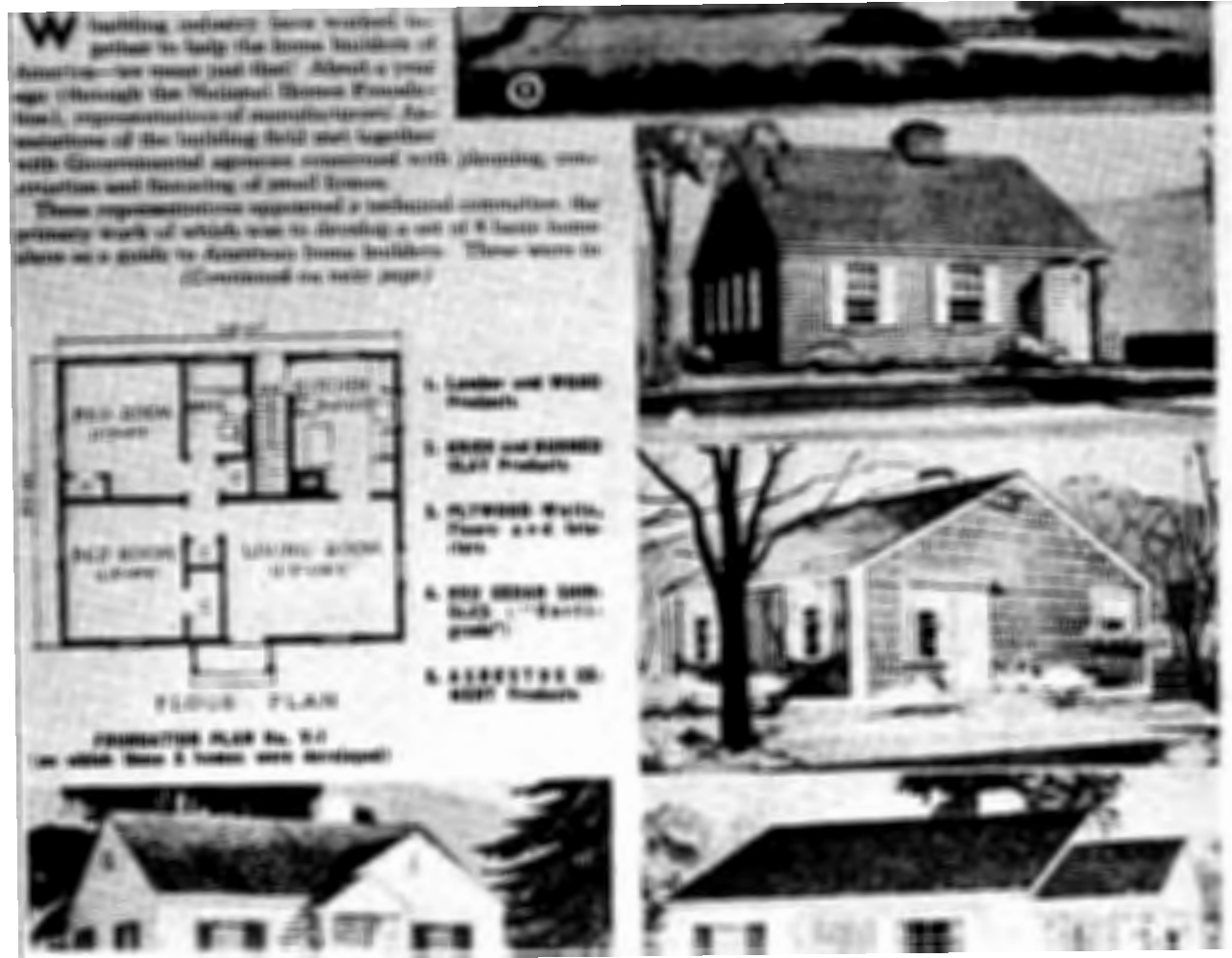

Figure 40. Smal1 Home Yearbook plan, 1941.

which will cost $\$ 4,400.00$ to build. Their savings and loan company estimates that the completed house and lot should be valued at $\$ 5,000.00$ on which the $S \& L$ will loan the maximum, $80 \%$ or $\$ 4,000.00$. Closing costs will amount to $\$ 150.00$ and the deposit or down payment will be $\$ 400.00$. Mortgage terms will be: the principle of $\$ 4,000.00$ and a fifteen year term loan at $\$ 50.10$ monthly to amortize principal and interest payments, including $\$ 14.50$ for insurance and tax reserves. The result is that the Robinsons will be paying only ten 
cents more than their previous rent for the purchase of their own home, expected to be owned free and clear in a relatively short period of fifteen years. In addition to their monthly payments, in lieu of rent, they will have maintenance costs and some utilities costs which they had not had to pay for their rented apartment, but presumably they have budgeted for this out of the savings they were otherwise able to retain out of Mr. Robinson's salary. We assume also that $\mathrm{Mr}$. Robinson has a modest life insurance policy to pay off the mortgage debt and his funeral expenses in the event of his untimely death or incapacitation. Mrs. Robinson is expected to remain at home and attend to the management of their new "chore-proof" house with five rooms and bath: living room, small dining room, a modern kitchen, and two bedrooms. Certainly, the Robinsons will have one or more children for that second bedroom before the decade is finished (Mr. Robinson will have served in the armed forces in World War-II in the interim, and Mrs. Robinson may have earned double her husband's old salary as a war worker in those next five years). 86

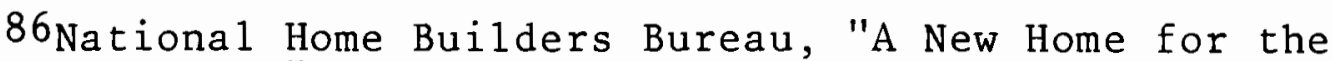
Robinson Family," Sma11 Homes Year Book (N.Y: NHBB, Inc., 1941), pp. 31, 36. The Year Book also characterized the combined Federal Housing Administration, savings and loan insurance, and Social Security programs as the "American Family Security Plan... Save, Amortize, and Retire," p. 9. 


\section{CHAPTER V}

\section{FHA INSURED DEPRESSION HOUSES}

The Federal Housing Administration mortgage insured builders' house of 1934 to 1942 was very 1 ikely to be a small two bedroom Colonial Revival Style cottage. My unscientific count of 27 houses in the 1938 FHA report finds that 62 percent or 17 of the houses are Colonial Revival Style, and one Mission Revival (in California of course), two Modern Colonial Style, two English Tudor or Cottage, and five others generally Modern. In pattern books, the ratio of Colonial Revival Style to all others is as high as 80 percent. Except for certain government housing projects which were notable for their designers and modern architecture, such as Greenbelt, Maryland, the preference for the Colonial Revival Style was clear.

The 1930s' FHA insured house was likely to have a full or at least a partial concrete cellar, was one or one and one-half stories high, two to three bedroom, one bath, had a separate dining room (albeit a small one), and showed a single car garage. Construction was conventional either balloon or western platform frame, unless partially masonry, with a trend toward the platform frame. There were cellarless homes built with wood floors over a crawl space, but no 
cement floors or grade-beam combined floor slab and footings. Interior finishes usually listed plaster on lath, both hardwood and softwood trim and moldings, hardwood flooring, and paneled cabinetry. A surprising number of these houses included built-in radio antenna and ground outlets. Kitchen and bathroom finishes might be either linoleum or other resilient tile or ceramic tile. All had some kind of central heating system, although there were a number of floor furnaces and wall heater units. Among the mechanical systems in the homes, the Hornibrook Residence in Klamath Falls, Oregon, was very unusual because of its

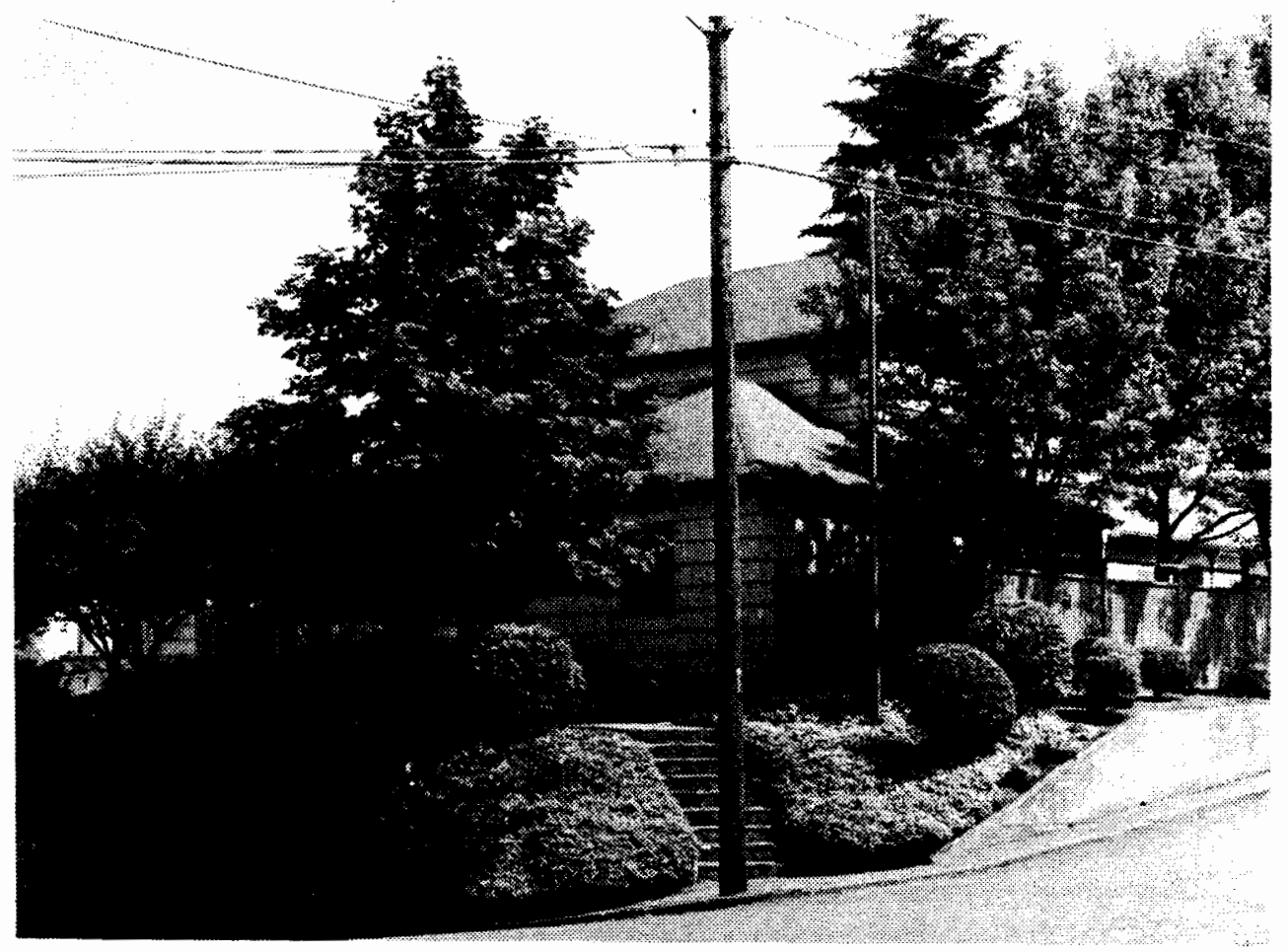

Figure 41. Dr. Carl W. Emmons Residence, Salem, Oregon. Modern Georgian Syle split level home, designed by architect Frederick H. Eley. One of the 1938 FHA report houses. 
geothermal central heating system, common in that area. A very few of the homes were in the custom luxury category, one each in San Francisco, Salem (Oregon), and Portland's Eas tmoreland. 87

The FHA houses in 1938 and in the next four years up to the effective halt in private home building in World WarII were both a continuation in style and construction of their precedents in the 1920s, but also maintained the

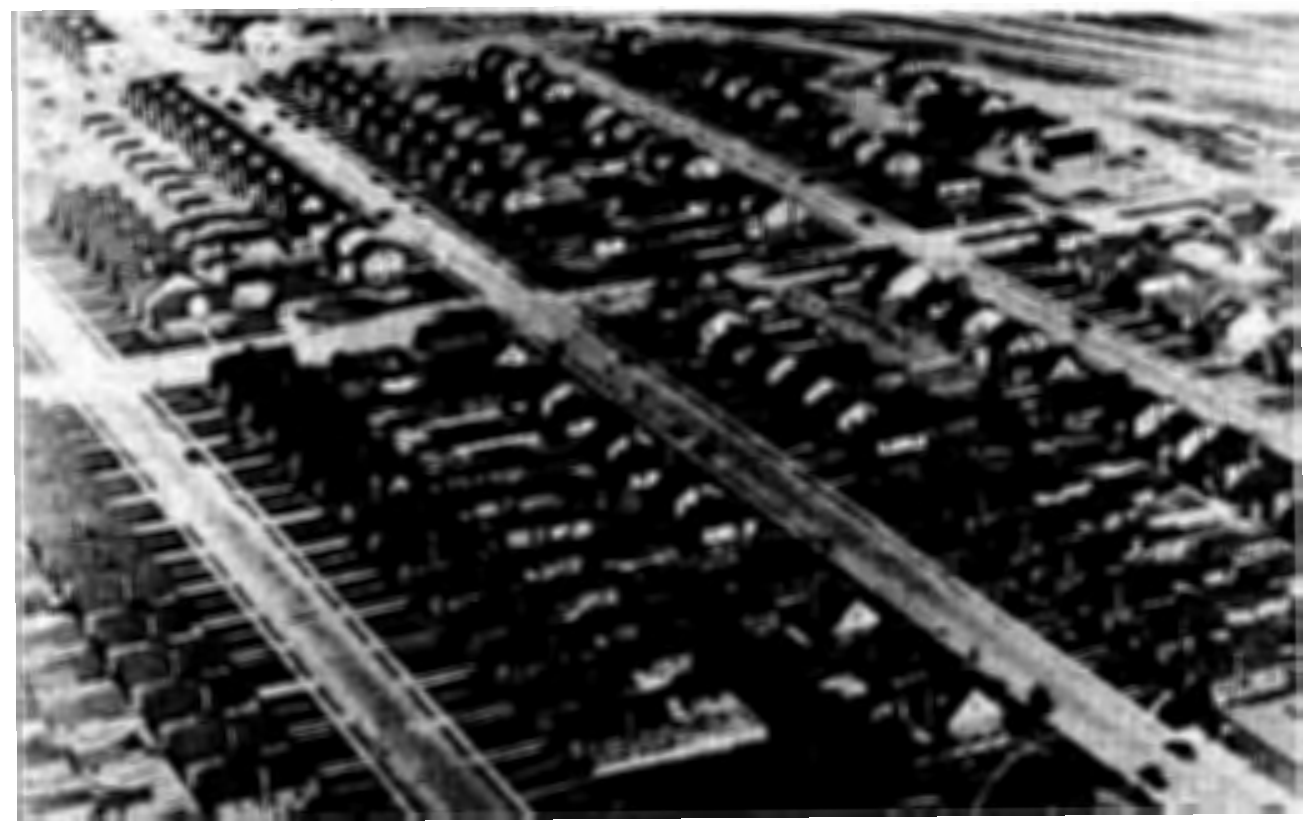

Figure 42. FHA homes development, Belmont Park, N.Y., 1939. From The Book of Houses.

distinguishing differences characteristic of the Depression years. The Depression FHA houses were generally smaller than the earlier average builders houses; although there was

87 FHA Sample Case Files for Housing, 1938. The houses which are described are a selection from boxes 2,18 , and 20 records in the National Archives, selected for the Pacific Northwest and also including other states' cities. 
a trend in the 1920 s to houses smaller than in the 1900 s and 1910s. The 1920s families appear to have been smaller and to have been separated from the older parents, aunts, and uncles who made up the extended families in the nineteenth and earlier twentieth centuries American households. The typical FHA house in the Depression was for the nuclear family only. As previously stated, the Depression FHA insured houses were predominantly in the Colonial Revival Style as were most other government built low income homes, and, almost without exception, appear to have been strongly influenced by the commonly available books on the style, especially the White Pine Monographs. Each of the Colonial Revival houses with a fireplace has a characteristically imposing chimney appropriate to the style. In the sample, more than 90 percent are architect designed, not tract houses, built on an infill lot within existing city boundaries; whereas most of the low-cost homes before 1934 were variations on stock designs by builders without architects. These architect designed houses are classified as builders' houses because they were not all exclusive designs for just a single client but in fact are just one of many similar houses within the same neighborhood. Many of the houses' documents indicate that they were built on speculation. Only the Resettlement Administration and other large government built housing developments were built outside or on the edge of established city areas and comprised uniform 
groups of new houses. The Depression built homes exhibit a uniformly high standard of correct architectural detailing and finishing no matter what their size and cost; the designers and builders knew the rules set by the styles and

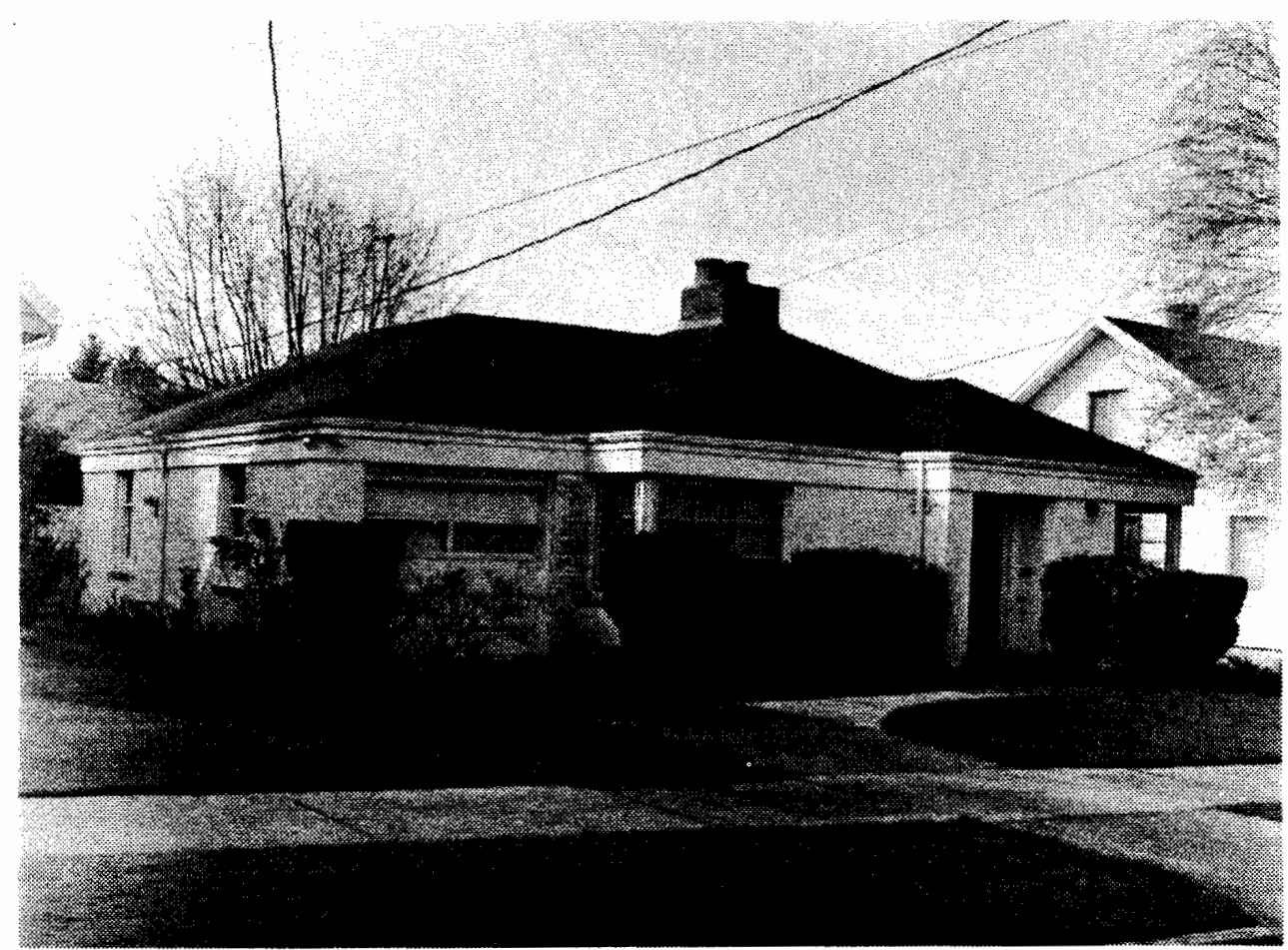

Figure 43. A Modern Colonial Revival Style house. One of the 1938 report's examples. 5131 NE 35th Place, Portland. Wallace Landreth, architect.

the prevailing building practices. There is evidence of a considerable amount of manual craftsmanship and skilled masonry or carpentry expended on these houses.

The construction qualities of the Depression houses are less easy to see, but the differences are there. New materials and practices were being introduced. Many of the houses are annoted on their drawings as being insulated, a 
newer development. The use of new interior wallboards is sometimes noted where plaster on lath was traditional, "Rocklath" plaster base and "Sheetrock" plaster board. Plywood sheathing, a "picture window," the "radio" outlets and one installation of telephone service conduit and niche for the phone set, "Firtex" insulation board, and a built-in barbecue are some of the new materials and systems noted on the specifications. Knob-and-tube wiring was used almost without exception and was not discontinued until after the war. Heating systems used all types of the current equipment with no special innovations except the local development of geothermal hot water heat in Klamath Falls, Oregon. Each house is presumed to have complied with the FHA "Minimum Construction Requirements" for 1938, although only a few of the house documents surveyed were so annotated. And, except for the note sometimes stamped or written on the construction documents that the house complied with the FHA requirements, none of the plans and specifications refer to any building codes.

Despite the examples and writings of the various modern architects, Moderne, Streamlined Modern, and International Style had very little influence on the FHA insured Depression builders' houses. In fact, there was a continuation of the 1920s' preferance for the various eclectic revival style houses, the Colonial Revival and the Tudor, French Provincial, and Spanish or Mediterranean throughout 

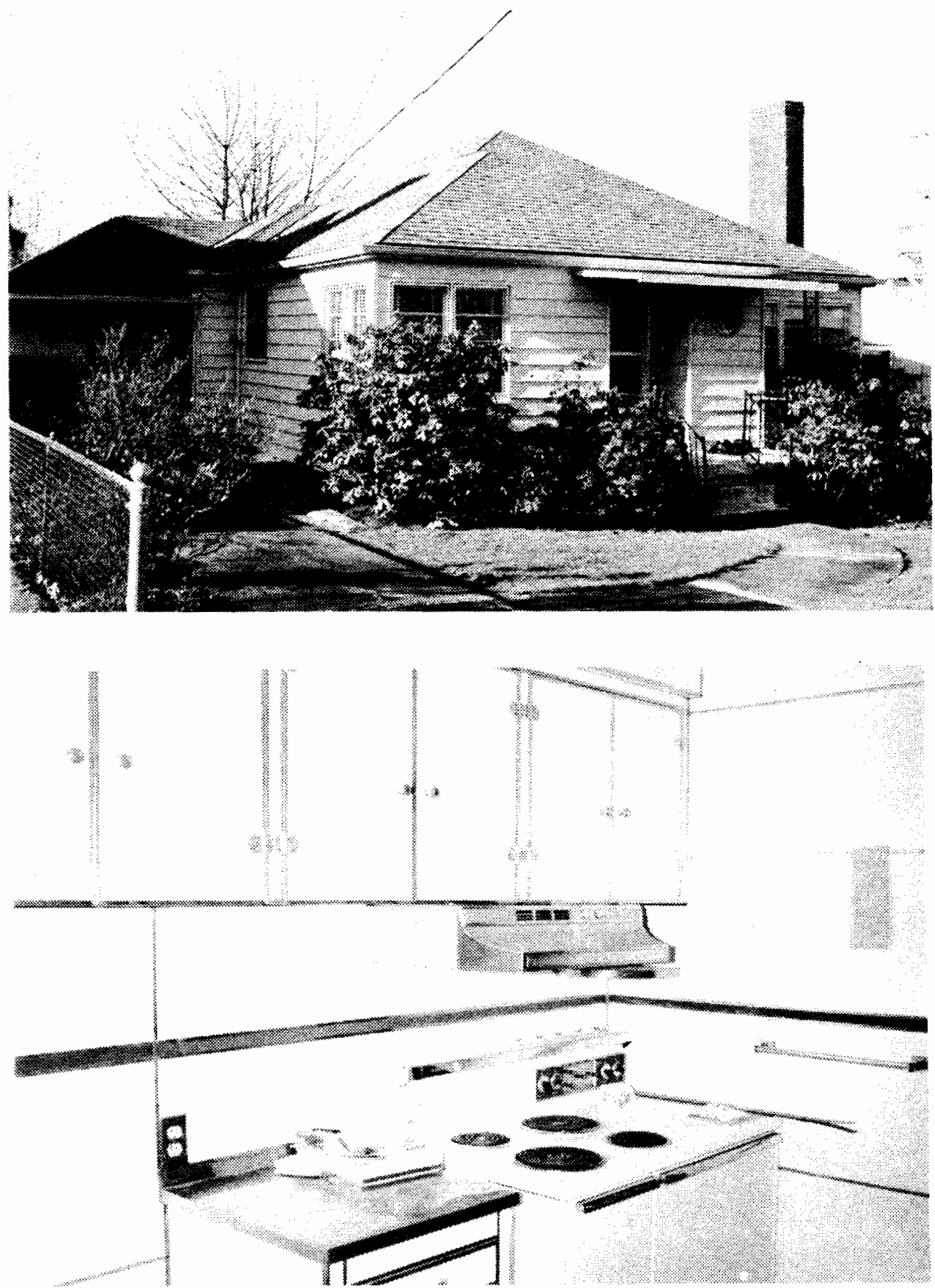

Figure 44. A modern builders' house from 1941. Traditional syle details are gone, but the customary finishing qualities are retained. This house has a streamlined interior utilizing conventional materials. New plastic laminate board is used for the kitchen cabinets with chrome trim (modern appliances added). $205 \mathrm{SE}$ 62nd Ave., Portland. 
the Depression. These styles' disciplines were well known to architects and builders; if you knew the rules and kept to them (design books were plentiful) even the most inept designer could arrive at a satisfactory appearing house without professional help.

THE MODERN STYLE THIRTIES' BUILDERS' HOUSE

Modern design was something else. The International Modern Style did have rules, rules of basic design which underlie all great architectural styles, massing, proportion, rhythm, light and shadow, transparency and opacity, balance and asymmetry, the hidden and the revealed, and a clear relationship between ornament and its functional derivation. But, recognition of these rules had been obscured by almost three centuries of concentration on formal effects, 1 imitations to approved ancient styles regardless of their relevancy to modern building programs and construction, and the use of the decorative elements of past architecture divorced from their functional basis in construction.

Very few architects had the educational background to adapt to Modern from Beaux-Arts discipline with comfort and facility. Modern was mostly seen as an opportunity to leave off customary finish and trim materials or to attempt blindly to emulate either an International style house or to experiment with something modern appearing and streamlined. 
Some curious regional architecture was more often the result and not a good example of the International style. Certain$1 y$, the usual home buyer was unacquainted with Modern architecture and much preferred the traditional styles---as remains true today.

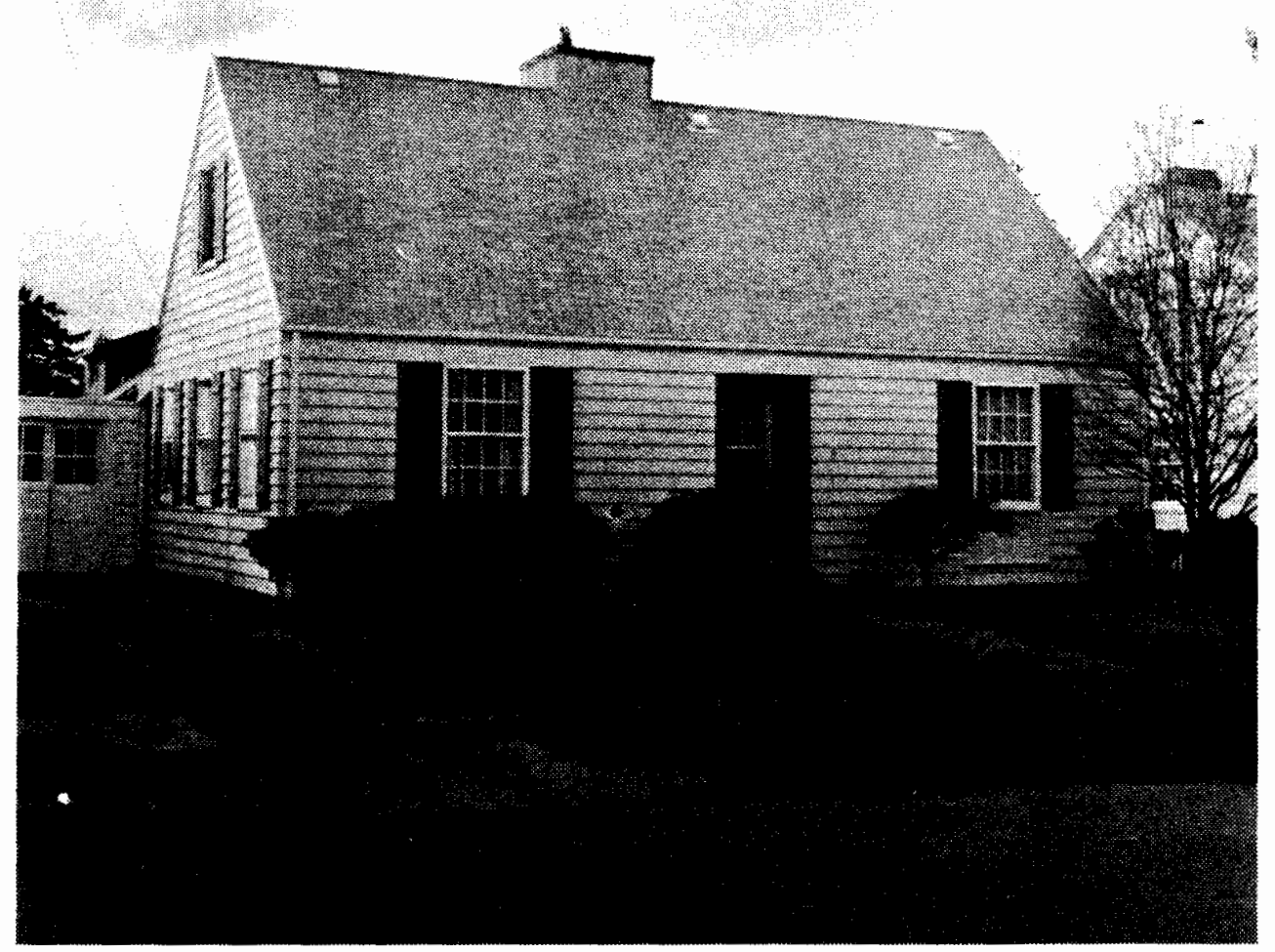

Figure 45. One of the 1938 FHA report houses. $2001 \mathrm{NE} 64$ th Ave., Portland. Johnson, Wallwork \& Dukehart architects. An Oregonian "Home of the Week," 28 March 1937.

Architectural Forum devoted its March 1939 issue to housing and extensively reported on The Yale Conference on House Building Technics held that February. This was the year of the two worlds fairs in New York and San Francisco. The conference's panelists spoke of hopes and ideals, but 
there was not much progress to report. Housing construction was down $14.8 \%$ compared to 1938 and $1.4 \%$ compared to 1937 . The average cost of building had come down from its "peak" in 1937 , and the rate of foreclosures had come way down--not all news was bad. There was concern over several provisions of the National Housing Act which were to expire unless Congress acted to raise the mortgage guarantee authority. Forum was recommending authorization of $90 \%$ loans for 25 year terms. Questions were addressed to whether there was a real housing shortage, costs, hopes (again) for prefabrication, large scale building, and standardization. 88

Ralph T. Walker, President of the Architectural League of New York, raised humanistic considerations, space and livability, which are not solvable by using new materials but by good design. He advocated more "... ascendant proportions rather than those of economic and political defeatism.", attention to community life, and the beauty of the city. He pinned his hopes on development of better lowcost building materials from research, naming work done by the USDA Forest Products Laboratory, Johns-Manville Company, and the Bemis Foundation at Massachusetts Institute of Technology (terminated by Pietro Belluschi when he was dean of MIT's architecture school). Walker concluded with

${ }^{88}$ Architectural Forum, March 1939, Vol. 70 No. 3 (N.Y: Time, Inc.). 
comments which typify the approaches toward housing in 1939:

An industrialist can understand that our national health depends on and demands an accelerated rate of obsolescence---the destruction of the old to make way for the new, and slum-clearance cannot scratch the surface.

Other articles in the March 1939 Forum discussed the possibilities of disposable houses of paper and socialized architecture. The houses and housing shown ranged from the traditional to modern in styles with an emphasis on innovative applications of industrial technology and speed of construction. The low-cost housing theme was continued in the April 1939 Forum where the editors lamented that auto sales had not slumped as badly as home sales. The predominant house was a four to five room cottage on one floor with the possibility of finishing additional bedrooms in the half-story attic if there was a peaked roof.

\section{OTHER EXAMPLES OF DEPRESSION HOMES}

A few non colonial styles are represented in the 1938 FHA sample. These other styles continued to be built both as custom homes and on speculation. Their cost was generally above the low-cost range of most FHA insured houses; and I do not have information on whether or not some of them were financed with insured mortgages or were conventionally financed. The home loan business for banks and savings and loan institutions was not limited to the FHA program. Except for their architectural styles, these other 

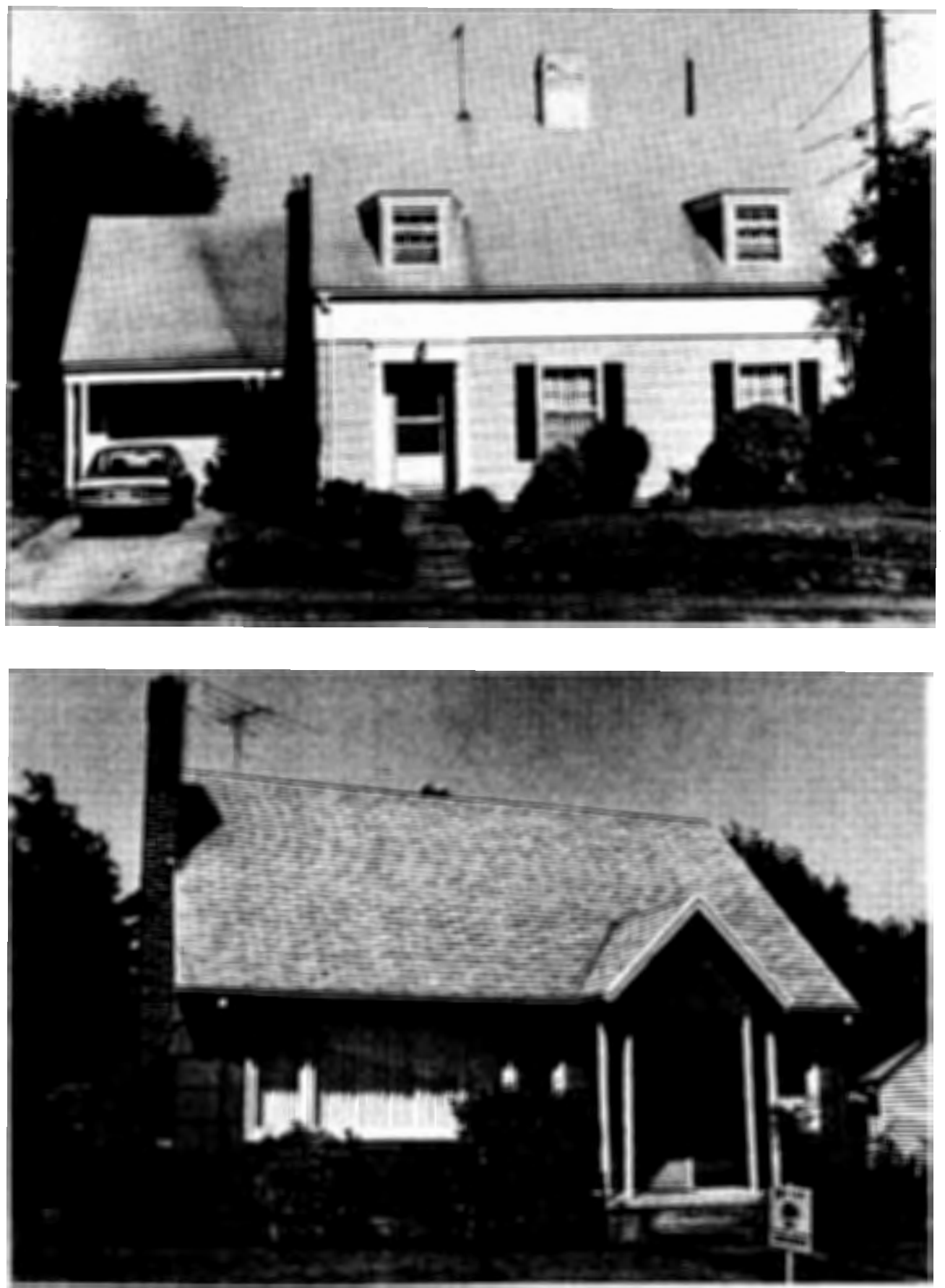

Figure 46. 1938 FHA houses in Portland. 2730 NE 70th Ave., Peter R. Danskov, designer, and 4315 NE 63rd Avenue. 
houses have the same care for detail, craftsmanship, and construction as the known FHA homes.

\section{ARCHITECTS AND DEPRESSION HOUSES}

Architects in the 1930 s both continued their gentlemanly practice of custom homes design and participated more in designing for the speculative builder. Many architects, like Jamieson Parker, saw their practices vanish in the bottom of the Depression, never to be resumed. Those architects who persevered throughout the Thirties took whatever work was available and accommodated to new conditions and tastes in style. Some of the more interesting work was done by those architects who were incorporating the International Modern principles in their work, custom and stock designs. The work of John Yeon, Van Evera Bailey, and Wade Pipes illustrates how different architects made a change from traditional styles to the Modern.

Wade Hampton Pipes is mostly associated with traditional designs for his very popular Portland residences. Only toward the end of the '30s did he begin to adapt to the International Modern Style influence. His 1937 Lyle Janz Residence in Riverwood is a modern house combined with Georgian detail elements producing a slightly awkward effect, less successful than his earlier homes. Pipes did a ful1y Modern residence in 1954 for Mr. and Mrs. John Montague Bates on Lake Oswego where he attempted to work 
with new materials, panels, and International style details producing a somewhat astylar house which lacks the craftsmanship of his earlier works (although the landscaping is exceptiona1). 89

Van Evera Bailey began his practice designing residences in the Arts and Crafts Style of the 1910 s and '20s. In the 1930s, he did a number of homes on speculation in Palm Springs, California, which are clearly Modern. For some years in the mid Thirties, he alternated back and forth between Arts and Crafts and International Modern, more Arts and Crafts in the Portland area and Modern in California. By the late Thirties and early Forties, he was doing completely International Style residences, the 1938 Fred 0. Hallwyler Residence, Lake Oswego, and the 1940 George S. Clifton and 1941 Sinclair residences, Portland. Bailey's change from traditional to Modern coincided with his collaboration with the architect Richard Neutra for work in California. Bailey's residential work would continue after World War-II and exert an influence on defining the west coast Modern Ranch Style home. His greatest influence on builder's house designing resulted from the stock plans he prepared both for sale through magazines like Country

Gentleman and House Beautiful and also from his own plan 
booklet sales material.90

John Yeon does not fit into the profile of a typical architect; strictly speaking in terms of registration to

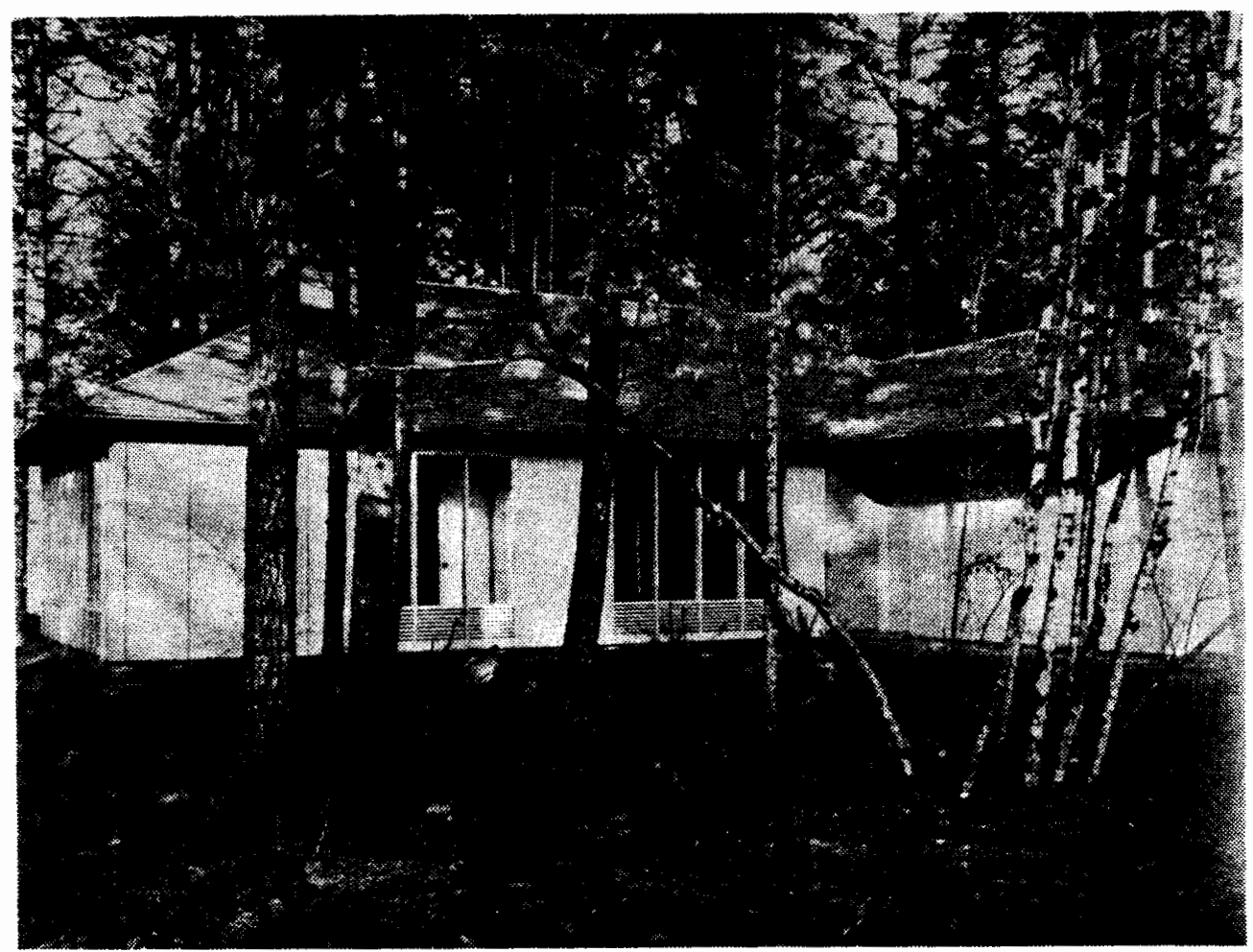

Figure 47. A Burt Smith builders' house designed by John Yeon in 1939. These houses received wide architectural press interest. Their details were widely copied. Forum.

practice, Yeon is not a registered architect; however, no architect in this area would question Yeon's place as a leading architect in the Pacific Northwest who has achieved national renown. Yeon began his career in architecture with some formal training in architecture's academic styles. His early experience as a designer for A. E. Doyle in Portland

90Van Evera Bailey Collection, Oregon Historical Society archives. 
exposed him to both traditional and early International Modern style buildings. While noted for his very modern residence designs, he did do one modern Colonial Revival Style designed residence in 1955 (Yeon called it "contextual" because of the site on Portland Heights) for a client who was expected to appreciate formality more than modernity. 91

For the purposes of this study of builders' houses, Yeon's designs for ten modular houses for builder Burt Smith in 1939 are particularly important. These houses, two in North Portland, two in Highlands, one occupied now by Yeon in Raleigh Hills, and the remainder in the Lake Oswego area, were requested by Smith who had built the Aubrey R. Watzeck House in 1937; and they exemplify the qualities which have been called the Northwest Style, derived from the International Modern Style and our pioneer buildings and regional materials. The Yeon-Smith builders' houses employ the two by eight foot module of a half width standard sheet of plywood, a practice which is a precursor of World War-II worker housing design, the ventilation panel separated from fixed window glazing, and many other elements adopted during the war that influenced postwar house design. Yeon is not and does not claim to have been totally original with his designs; he admits to have probably been influenced by the published work of other modern architects and possibly by

${ }^{91}$ Located at corner of SW Jackson and 19 th streets. 


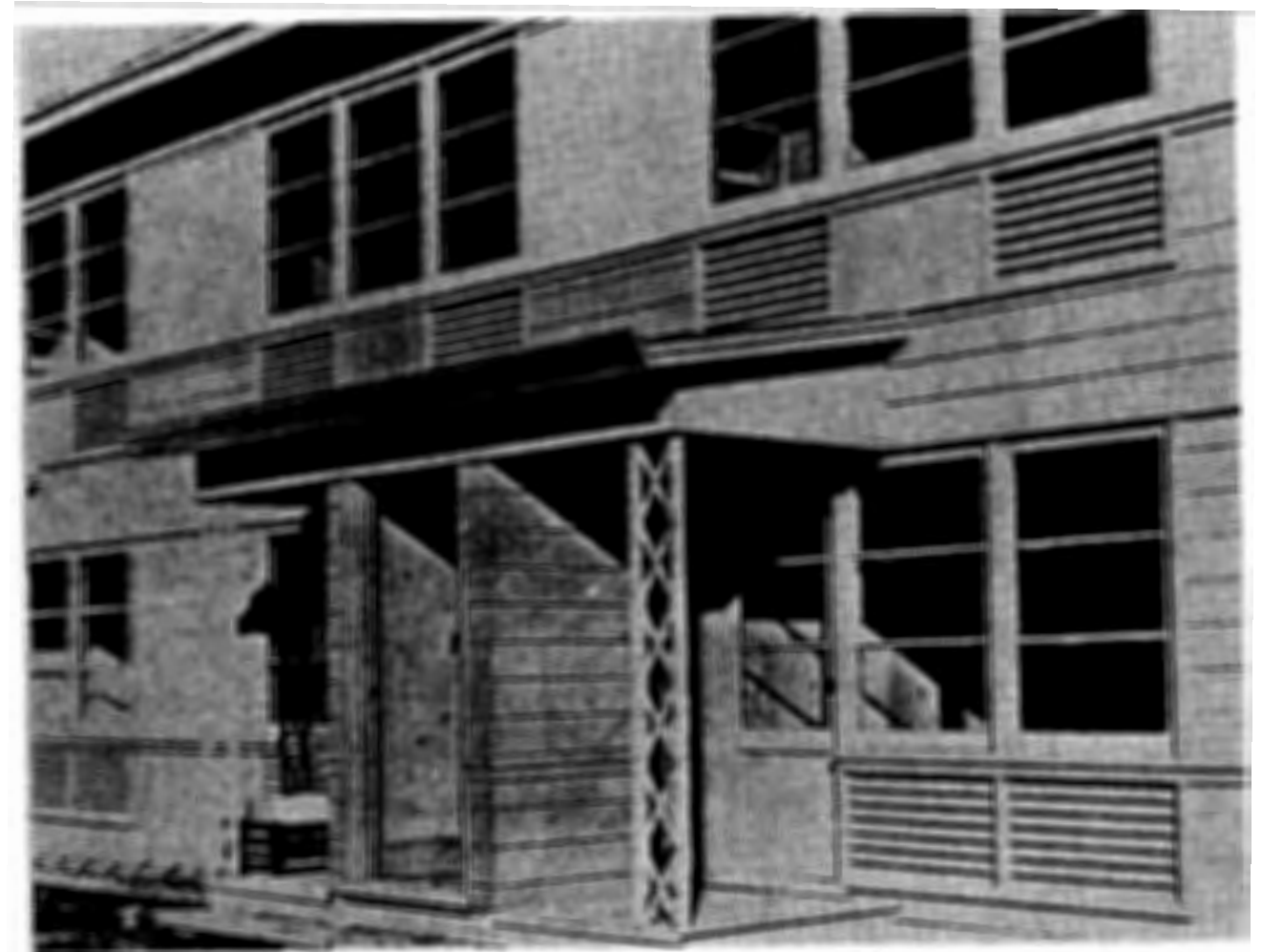

Figure 48. Use of the fixed window 1 ite and separate ventilation panel in defense housing. Vanport, Portland, 1942. Library of Congress collection.

studies for prefabricated and industrialized houses. Yeon says that his family connections to the Pacific Northwest lumber industry did not give him any special interest in new wood products; however, his Burt Smith builders' houses were among the first, if not the first, to make architectural use of the potential found in the newly developed exterior grades of plywood.92 And his work was a forerunner of the Fir Plywood Assoc. by Binfords and Mort, 1955), pp. 88-93. 
changes to be made in the later 1940 s after the war. 93

93Alfred M. Staehli, notes on interview with John Yeon at his home, 25 September 1986. His plywood module panel houses were published in Forum, April 1939, Pp. 318-319, and in House Beautifu1. 
CHAPTER VI

WART IME HOUS ING INFLUENCES

Builders' house activity was suspended during World War-II. Even before the United States entered the fighting at the end of 1941, the Federal Housing Administration had been fully occupied with the job of planning housing for the vast army of defense workers.94 Mobilization for the war in the form of defense workers' housing and military housing construction began to replace the normal building of single family homes. Architects began to receive commissions to design defense and military housing, certain materials became in short supply or were placed under priority restrictions, there was a new urgency to industrialize the building of housing, construction labor began to vanish as workers were drafted into the military, and government and private agencies shifted their interests to meeting defense needs. FHA was especially proud of its accomplishments toward aiding single family housing up to the outbreak of war. 218,035 new homes had been built in 1941 with $40 \%$ of them privately financed due to, according to the agency's

94FHA, Eighth Annual Report, December 1941 (Washington: Government Printing office, 1941), p. 3 . 
report, its technical standards and quality control.95 The Federal Housing Administration Title II new homes program had enabled the building of $\$ 6.4$ billion worth of new housing units for sale and rental by 1944 , more than onethird of the total of 1.2 million houses built in the 19351944 period. According to an Oregonian story in March 1945, $\$ 17$ million worth of new homes had been built in Oregon.

Existing federal housing agencies began to change their emphasis from normal to war preparedness before the general building industry was much affected. The Farm Security Administration built a "trailer camp" defense housing project in May 1941 in San Diego, California.96 Others followed at other defense industry sites throughout the west coast. The U.S. Housing Authority. created by the Wagner-Steagal1 Housing Act, turned from general public housing to planning, building, and maintaining defense housing projects.

Defense preparation and wartime building resulted in many changes in the customary house building methods and use of materials. Some housing units were planned for postwar retention for public housing, but many more were planned to meet the exigencies of the wartime conditions and were expected to be razed when the emergency was over. In order

\section{Eighth Annual Report, p. 11.}

96Farm Security Administration, photographs of trailer housing, May 1941. Library of Congress, Washington, D.C. 
to conserve critical materials, normal building codes were liberalized to allow substitute materials, to save materials, and to permit new labor saving construction innovations.

Before there could be local public housing projects, locally constituted public housing agencies had to be created to build and administer them. The Bremerton Housing Authority was authorized in July 1940 under the provisions of the 1937 Wagner-Steagall Housing Act to build permanent low income housing at this naval station. 97 The National Defense Housing Act of 1940, The Lanham Act, revised the older laws and gave additional authorization for government agencies to begin planning and building defense housing. After the war, it was extended in 1945 for veterans' housing, expiring in 1953. Within a year most of the war housing projects were underway and the change from peace to war construction begun. In response, other local public housing authorities began to form in defense industry impacted areas around the nation. However, there were many leaders who did not see any particular need for substantially increased new low income house building; The Housing Authority of Portland was organized in December 1941 despite

97 Housing Authority of Bremerton. Notes from correspondence cited in the public information booklet on the project. 
substantial opposition to public housing. 98

The scope and need for rapid completion of these defense projects was unprecedented. Every resource developed by the architectural profession and building industry

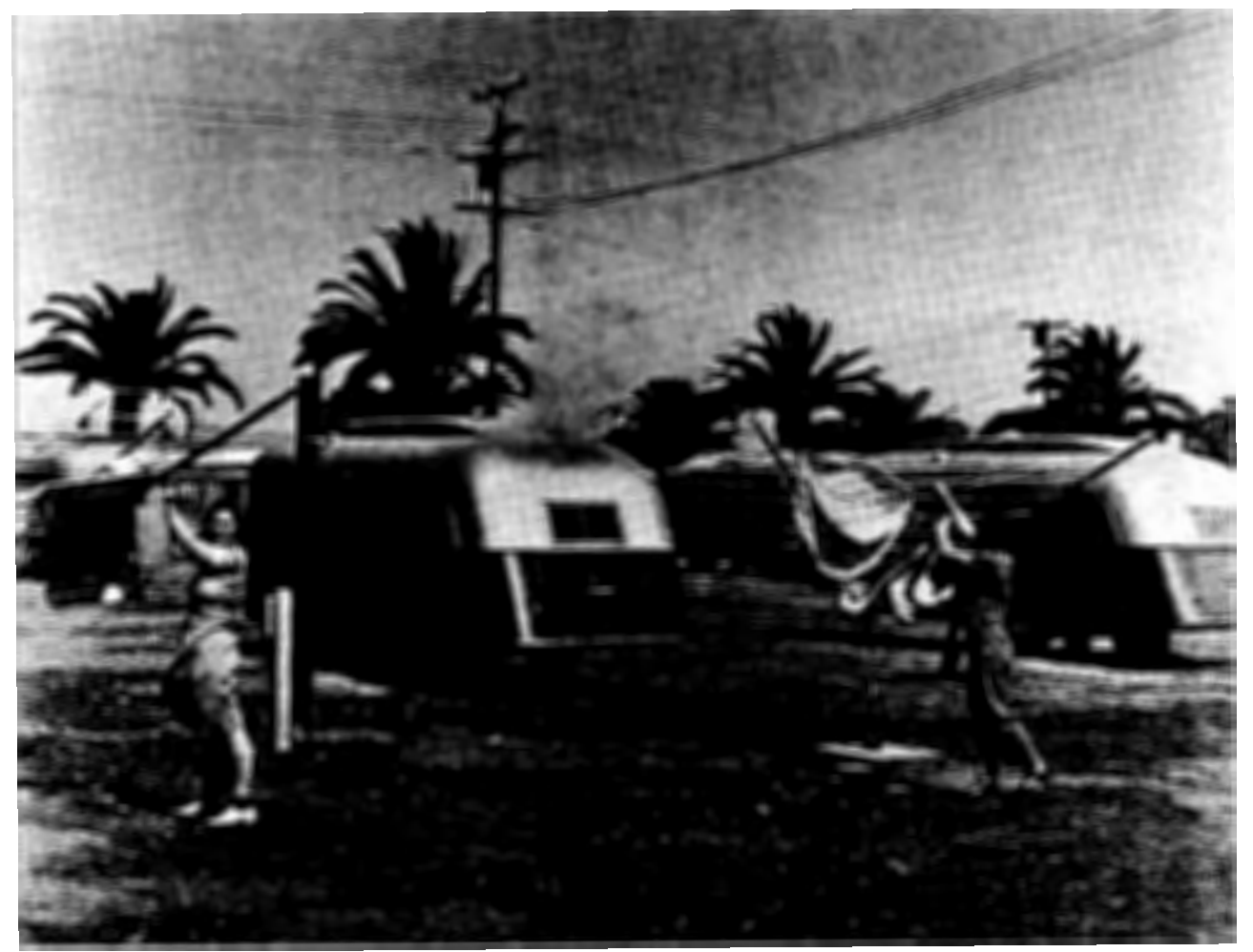

Figure 49. FSA trailer camp for defense workers near San Diego, California, 1941. FSA photograph, Library of Congress collection.

98"Should Portland Have a Housing Authority," The Oregonian, 2 March 1941, magazine section, P. 4. This article contained the opposing views of John R. Latourette, pro public housing, and Frank H. Hilton, against, both attorneys. Latourette cites the accomplishments of U.S. Housing Authority rooted with presidents Hoover and Roosevelt and endorsed by presidential candidate Wendell Wilkie; and Greenbelt, Maryland, is mentioned as a successful example. Hilton opposes public housing because it does not succeed in helping the homeless, and because it has too high income limits. Portland's high rents are mentioned by Latourette as a factor for public housing. There is no argument with FHA. 
was needed to plan new communities for thousands of displaced families, to meet critical construction deadlines, and to build without recourse to many traditional materials which had been diverted to the war effort, and build without the core of experienced construction labor now thinned by military service and war industry demands. The architects and housing agencies responded in a variety of ways.

Six defense housing projects in the Pacific Northwest are of special interest because of their importance at the time and as indicators of the changes for new homes after the war: Vanport and Columbia Villa in Portland, Tongue Point Naval Air Station in Astoria, Oregon; and McLaughlin Heights in Vancouver, Westpark in Bremerton, and Yesler Terrace in Seattle, Washington. Like the Depression FHA mortgage insured houses, these examples are selected because they were prominently written about in the building industry and public press and had available documentation which was accessible. To the extent that it was possible to compare these projects with other ones around the nation, they appear to be representative.

The public housing built in the Navy town of Bremerton, Washington, was planned to remain as permanent low income housing. Westpark, as the project was named, was designed for a series of low ridges on what was the west edge of the city in 1940. The architects, F. A. Naramore, Clyde Grainger, and Perry B. Johanson, Seattle, designed a 

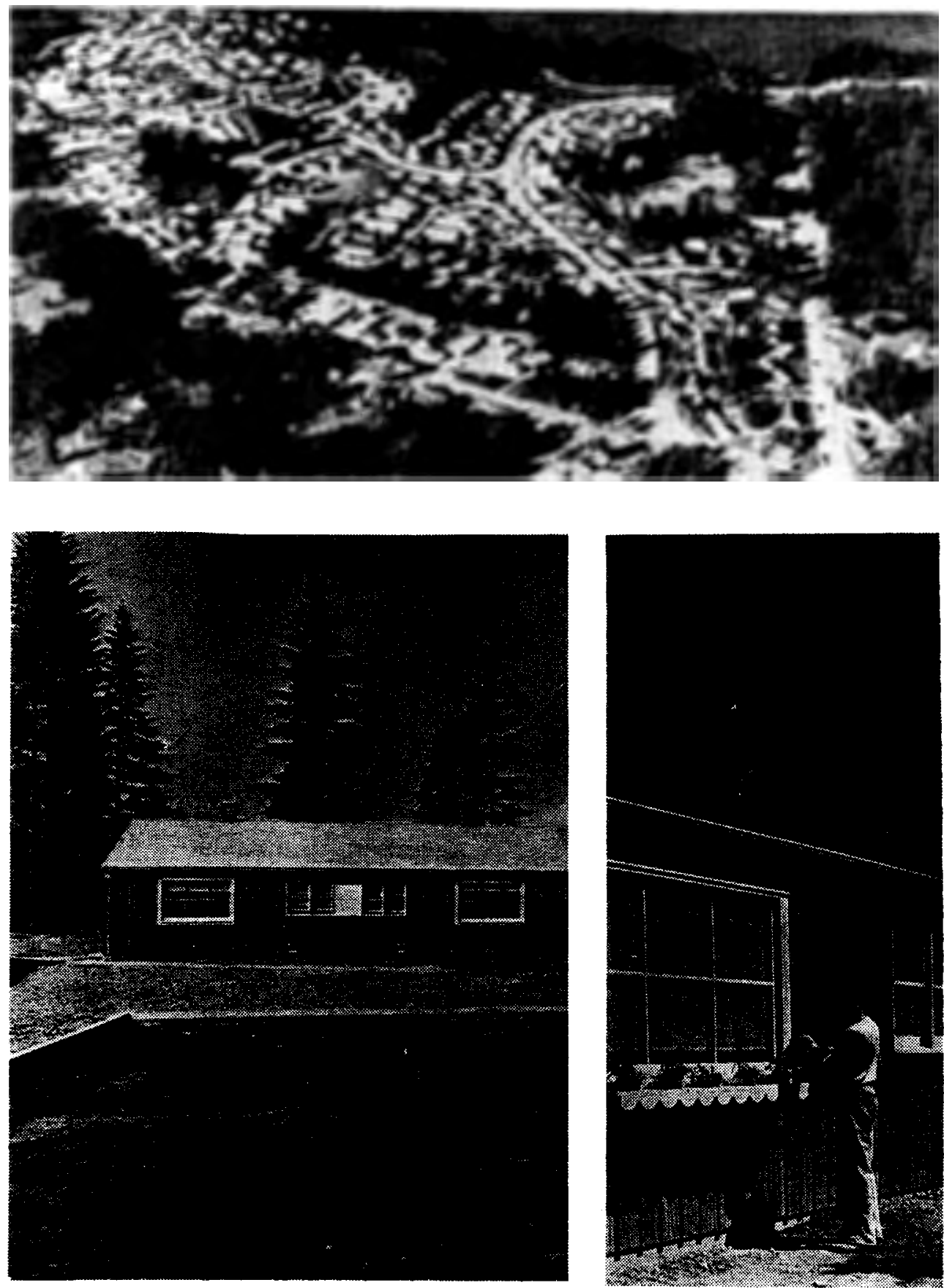

Figure 50. Westpark, Bremerton, Washington. Aerial view by Roger Dudley, The Book of Houses. Homes views by Public Housing Administration, Library of Congress collection, 1941. 

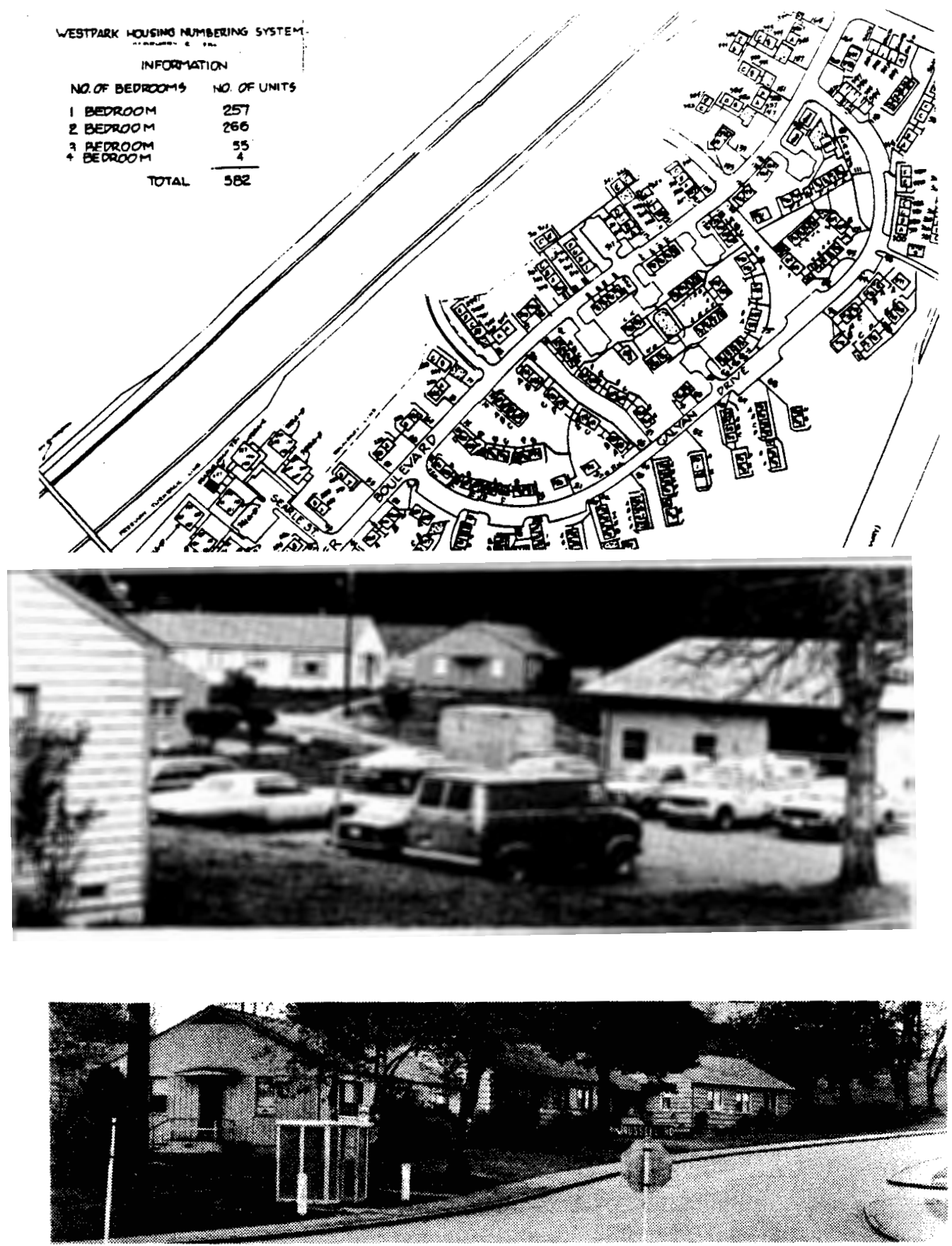

Figure 51. Site map and recent photographs of Westpark, Bremerton, Washington. 
series of one and two story single family, duplex, and fourplex housing units sited in the Greenbelt, Maryland, manner along winding vehicular streets with grouped offstreet parking areas, and separated pedestrian circulation. The wood frame buildings are Northwest Modern in style with stained, now painted, cedar shingle and board-and-batten siding, low broad roofs and eaves. Rapid building was accomplished by designing for a system of on-site preassembly and pre-cutting:

New systems of construction were evolved, and mass production methods adapted to expedite the project. An example was the establishment of a mill on the site where power saws and other equipment made quick work of cutting and finishing lumber to the proper lengths and sizes. Plumbing installations were made in a single unit, shop assembled and put in place. 99

Westpark is in most.respects a typical public housing project. It has the design element qualities which were influencing architects in the 1940 s and in the decade which followed the war, the influences of the 1920 s and early 1930s' new towns planning and social organization theories regarding progressive public housing. Like Greenbelt, the architects designed Westpark home exteriors in the Modern Style, not a severe International Modern but an attempt at a regional response utilizing regional building methods and materials. The interiors are less regional, simple and

${ }^{99}$ Housing Authority of Bremerton, Westpark, information booklet on HAB public housing projects. The project was inspected in April 1986 when the notes were made. 
economical, with prefabricated shelving units and cabinets without doors, painted gypsum drywall finished walls and ceilings. Despite the attempts made to provide architectural diversity and good planning, the public housing stigmata remains evident, a certain uniformity of just good enough maintenance, no garages, little occupant personalization---although there are some flower beds and occupant erected fences.

Yesler Terrace, Seattle, Washington, occupies a prime hillside site on the south side of Capitol Hill, an area locally referred to as "Profanity Hill." Planned like Westpark as a permanent public housing development, it was better built than the later temporary war housing and was an attempt by its architects, J. Lister Holmes, William J. Bain, John T. Jacobsen, William Aitken, and George W. Stoddard (of prewar Colonial Style houses), to meet the need for socially responsible low income housing on a central urban site. The published information on the project was directed to its planning and provisions for community services, not to its construction. Yesler Terrace appears to have been conventionally built without significant prefabrication. An interesting design feature is the awkward and stereotypical use of the " $V$ " form for entrance roof supports and the slanted entrance pylons identified with 1940s' Modernism. Yesler Terrace is fitted into the general grid plat of Seattle; although, the same Greenbelt 


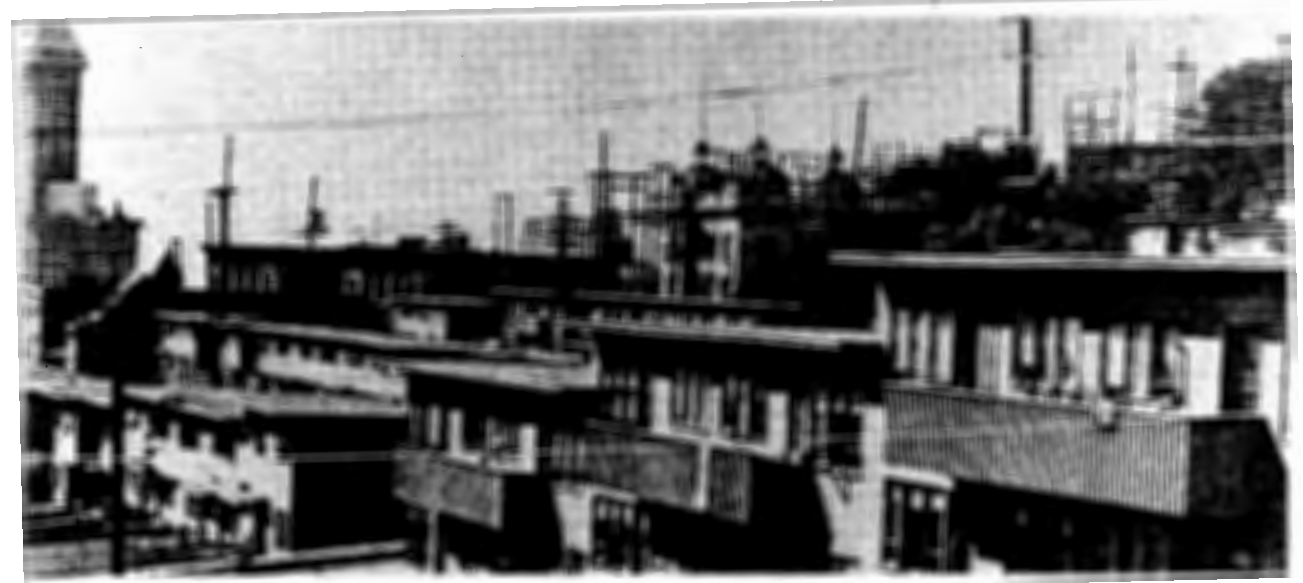

Figure 52. View of the Yesler Terrace project, Seattle, Washington. Public Housing Administration, 1941, for defense housing. Lib. Congr.

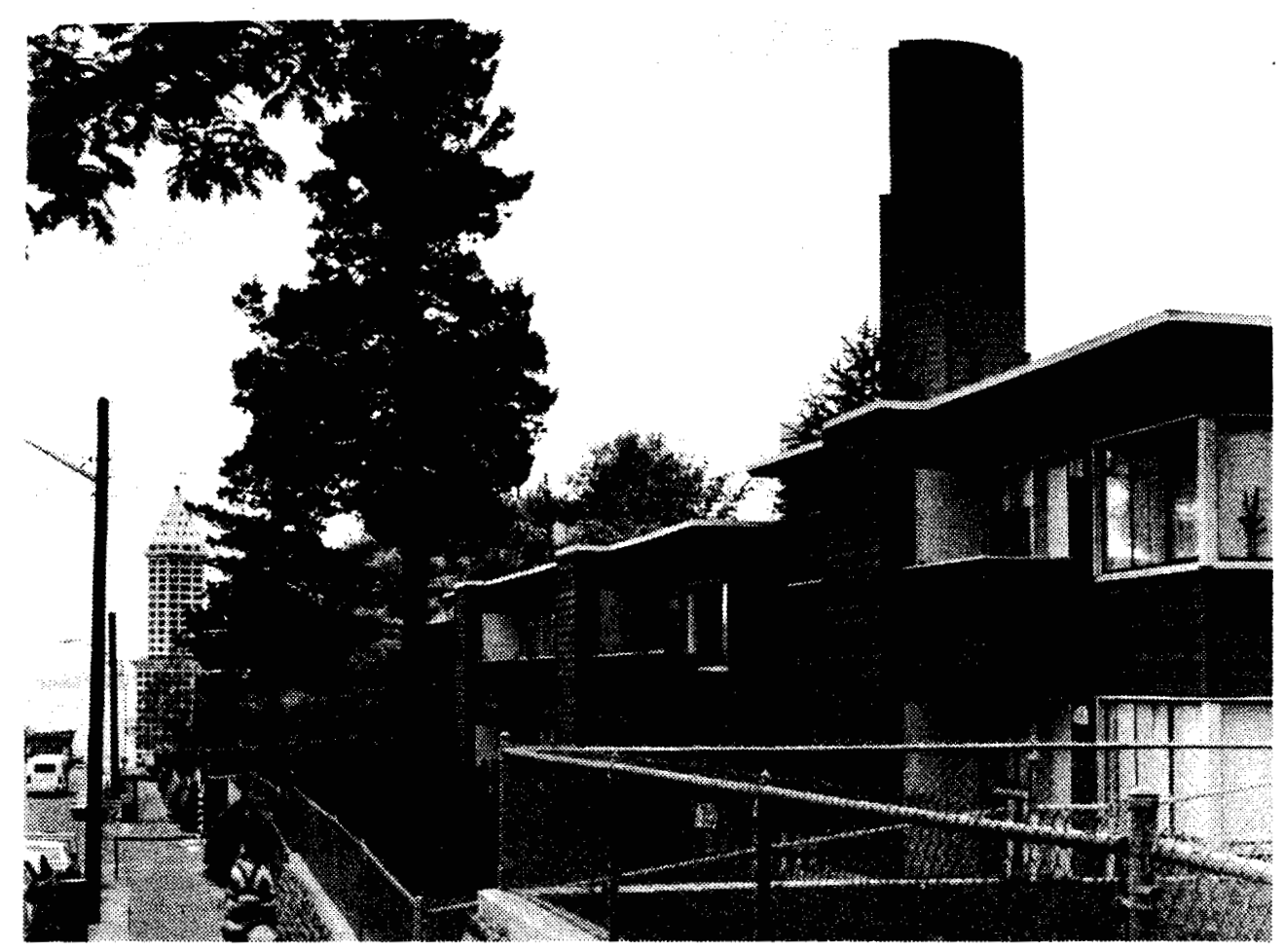

Figure 53. Details of Yesler Terrace project, balconies and front yards. 
influenced separation of vehicular and pedestrian traffic is there. Even more than Westpark, Yesler Terrace has a distinctly "project" appearance, grouped garbage cans near the front entrances which face the pedestrian walks and common yards between the units, unsheltered automobiles in off-street parking areas. More serious than at other public housing developments, Yesler Terrace is imposing a ghetto ambience on the whole neighborhood, too much sameness concentrated in a single prominent area.100.

Westpark and Yesler Terrace were reported on in the architectural press as examples of how prominent designers were meeting public housing needs. Architectural historian Talbot F. Hamlin cited several Farm Security Adiminstration projects, Woodville Garden Houses, Tulare, and Mineral King, California, Harlingen, Texas, and Eleven Mile Corner, Arizona, for their approaches to low-cost housing, noting particularly the wood frame construction and "grade beam" and concrete floor slab foundation for the Woodville homes, a prototype for this kind of construction. 101

Architect Van Evera Bailey's designs for housing at Tongue Point Naval Station, Astoria, National Housing Agency, FPHA, 1942, were a continuation of his exploration

100 Notes on inspection of the project in Apri1 1986. Also: J. Lister Holmes, "Yesler Terrace Housing," Pencil Points, November 1941, PP. 684-89. 720 .

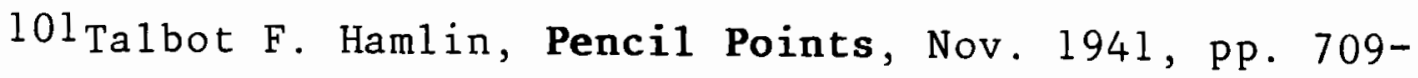


of the Modern Style in simple wood frame homes. Like Westpark, these houses had a vertical board-and-batten siding on wood framing. Their construction was conventional, but the interiors showed an unusual use of wood paneling used as minimal separating partitions and as decorative relief from the otherwise plain walls and ceilings.102

McLoughlin Heights, Vancouver, Washington, was in 1942 the site of one of the largest public housing projects ever planned and built. The city's fledgling public housing authority faced an emergency as the proposed influx of war workers and families would triple the city's 6,000 homes and quadruple its population. 103 Combined with other defense building and remodeling in the Portland-Vancouver area, every available architect was pressed into the work of designing and building this housing.

Architect Pietro Belluschi was responsible for planning and designing housing and the community facilities for McLoughlin Heights in what amounted to a major urban design and housing plan. He was interested in the problem of accommodating the needs of many different levels of society in a single community, the need to provide for recreation and a sense of common purpose to "...keep the boys from raising hel1." The McLoughlin Heights project

102 Van Evera Bailey, collected documents, Oregon Historical Society archives.

103Key Hartsook, "Plan 13,500 Houses, Vancouver Worried by Project," The Oregon Journal, 17 October 1942, p. 1 . 

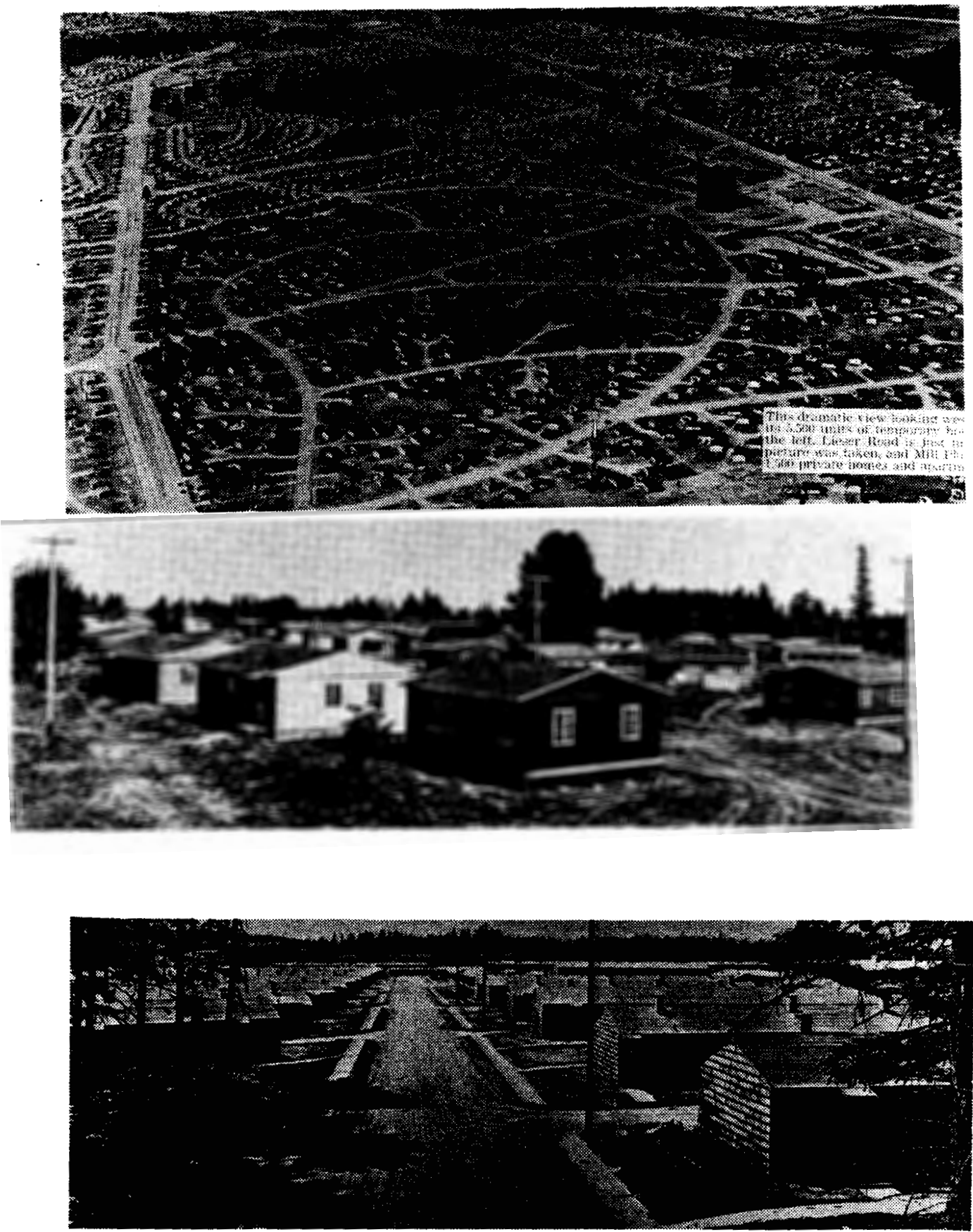

Figure 54. McLoughlin Heights, Vancouver, Washington. Aerial View from Vancouver PHA booklet. Homes views from Library of Congress collection. 

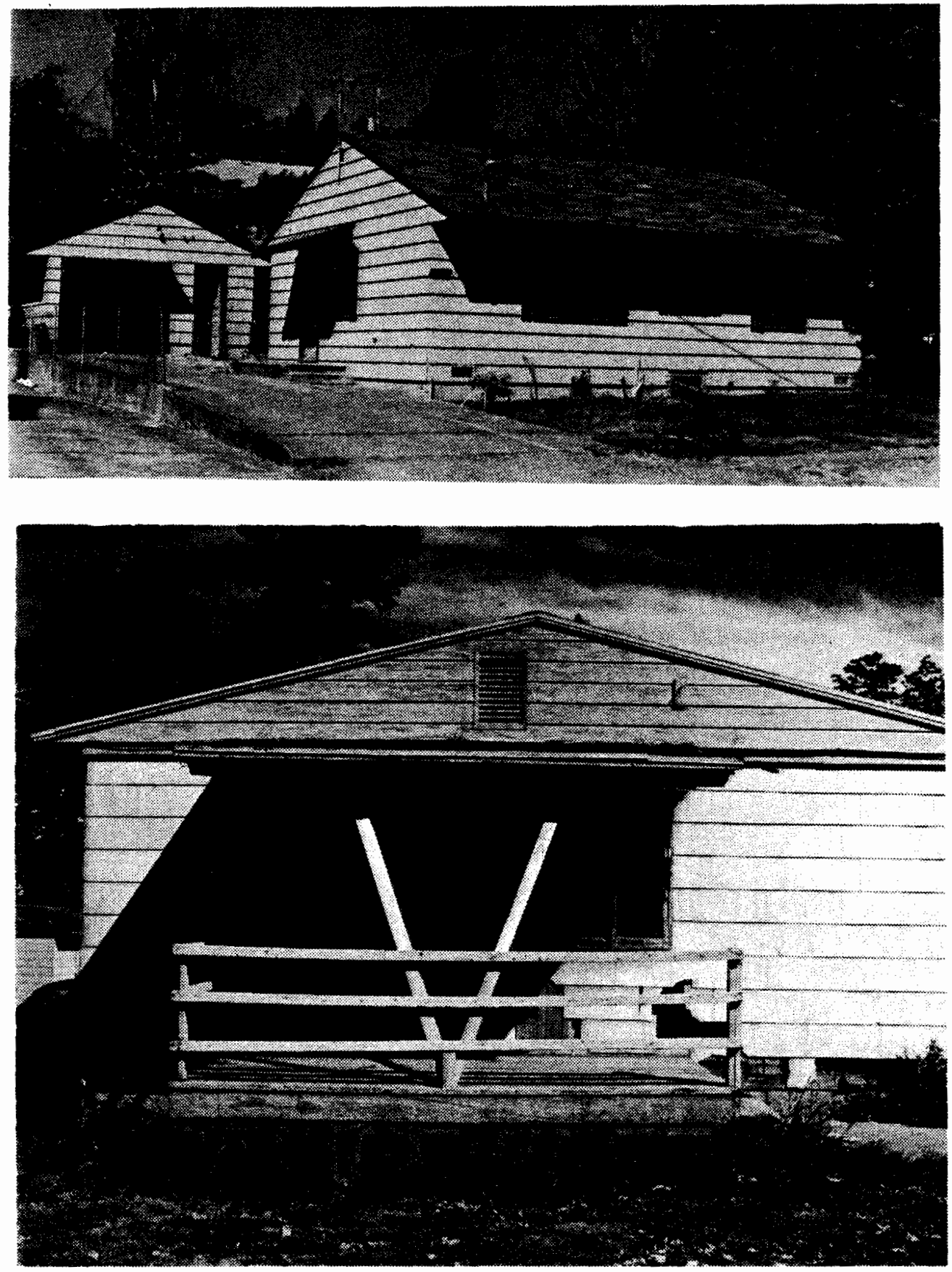

Figure 55. Defense housing in Portland and Vancouver, adapted for postwar private homes and rentals. 
included one of the first integrated shopping centers, which Belluschi designed, and he also worked on the housing units. The plan of McLoughlin Heights conformed to the prevailing system of looped streets and cul-de-sacs fed from a main avenue. To an extent, the streets conformed to the natural 1and forms. Belluschi remarked that the tenants personalized the development homes with their own trellises and gardens, humanizing the homes which look so very bleak in the early aerial photographs. 104

The McLoughlin Heights homes were site-prefabricated. Framing was economical, not designed for permanence, a system of wall studs installed with the wide face flat. Roof trusses combined ceiling joists and rafters in a single assembly. The framing system for the homes was given to Belluschi, and he believes that it may have been developed by architect Hugh Stubbins at Massachusetts Institute of Technology for defense housing. The building production technology of the defense housing was being absorbed by the designers who were to build the millions of homes after the war even if the goal of mass production of prefabricated homes was not met.

Mr. Belluschi believes that the problem of prefabrication has been its boring product, its failure to meet

104 Notes of interview with Pietro Belluschi, 3 September 1986. Federal Public Housing Administration, National Housing Authority, 1943 photographs, Library of Congress. file 2472. Betty $\mathrm{H}$. Cummings, Housing in War and Peace (Vancouver: Housing Authority of the City of Vancouver, 1972). 
diverse needs. Contrary to Buckminster Fuller's statement that if automobiles were built the way homes are, they would cost $\$ 500,000$. instead of $\$ 500$, the anticipated cost

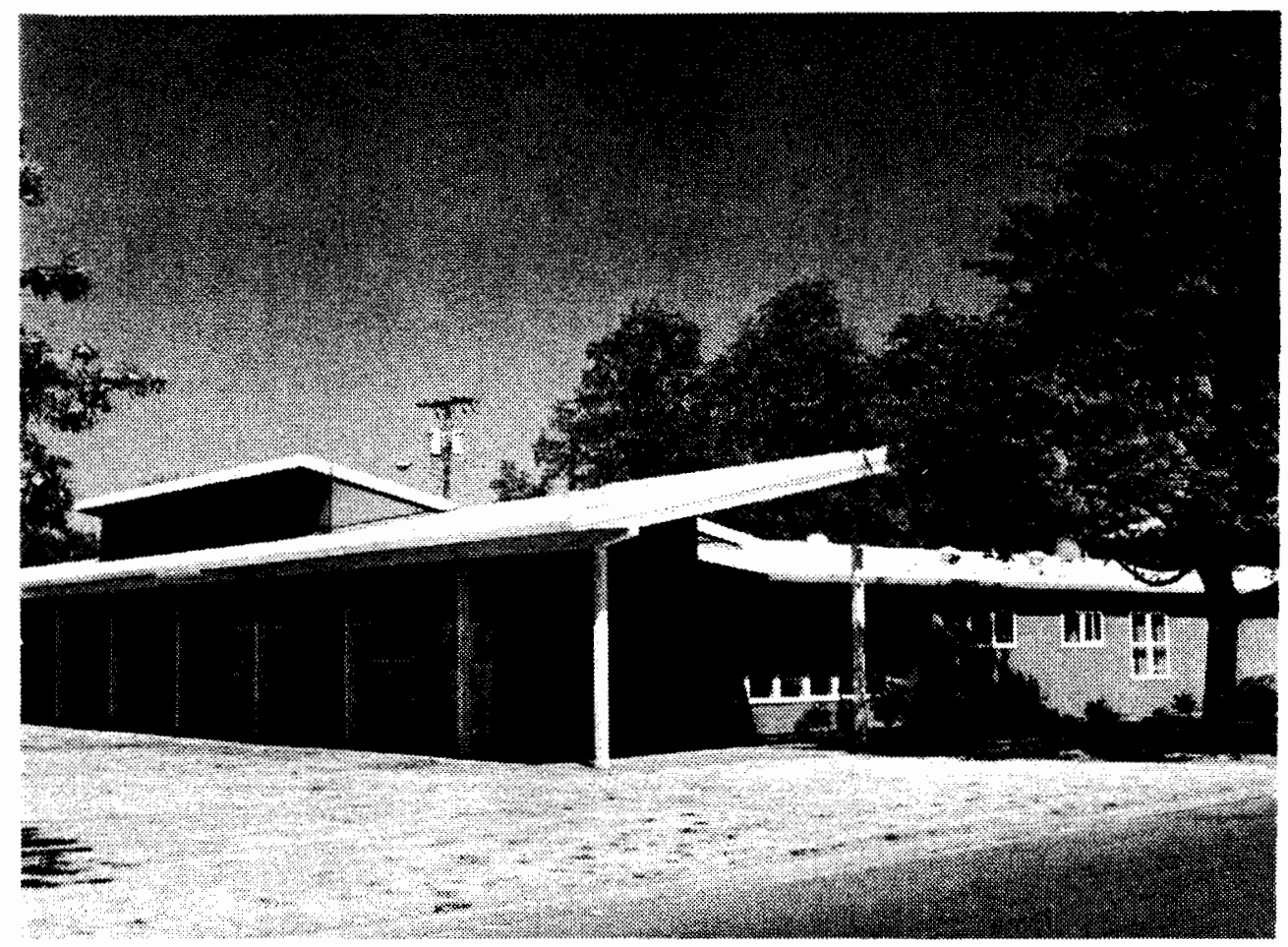

Figure 56. Mc Loughlin Heights Community Center buildings. Now, the School District offices.

savings from prefabrication were never achieved in practice. Belluschi believes that there may be some hope for the mobile home (manufactured home) once its "cuteness" is done away with.

The other defense housing projects built in the Portland-Vancouver area, Puget Sound area, and other west coast cities were similar, frequently employing the same standard designs. The photograph of the Vernon de Mars designed project of row houses for the Farm Security Administration 


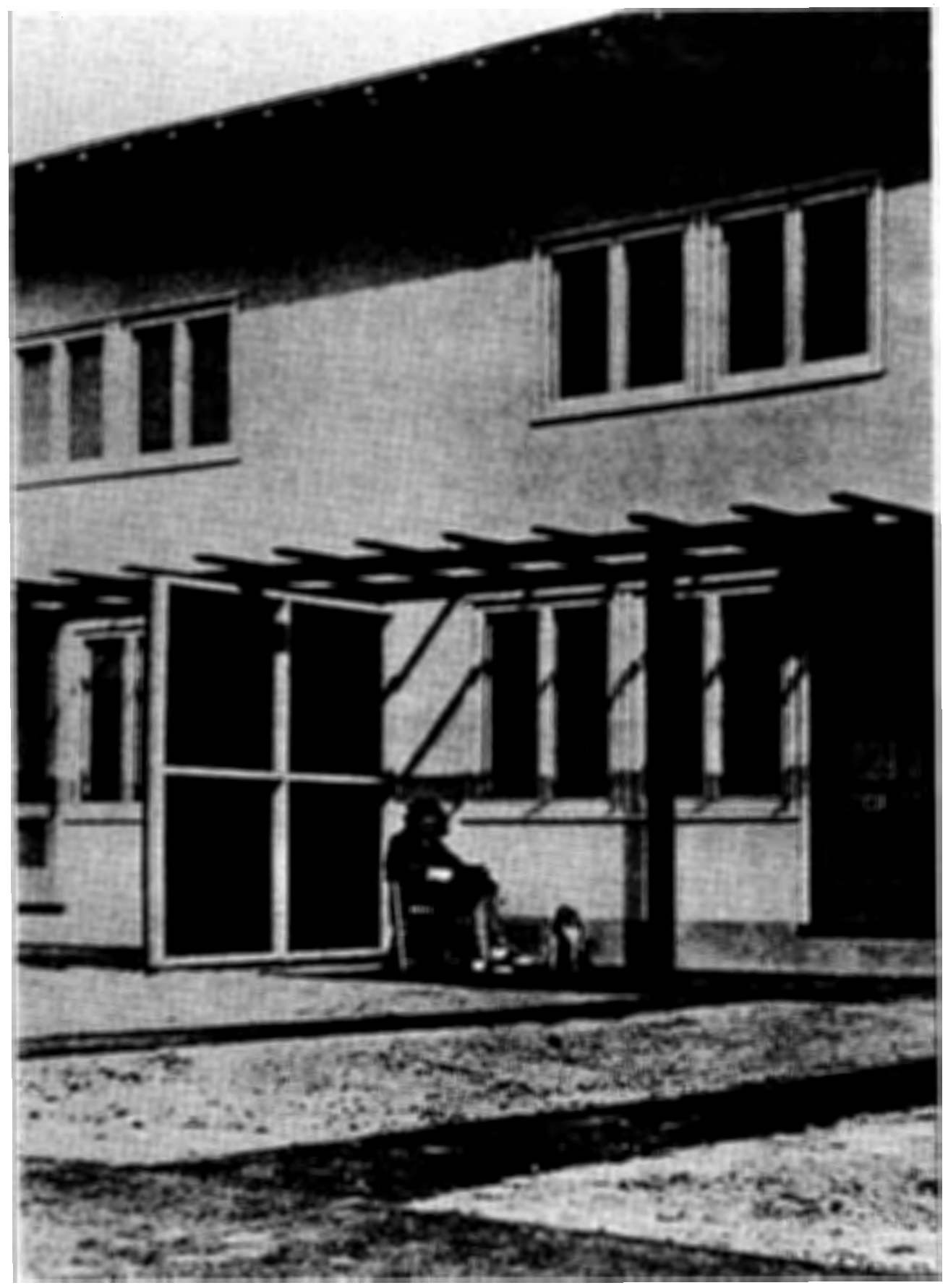

Figure 57. Farm Security Administration wartime housing project, Taft, California, 1942. FSA photo for Museum of Modern Art exhibit, Library of Congress collection. 
in Taft, California, 1942, shows it to be very similar to the McLoughlin Heights housing or to most other projects. Vanport, the Henry $J$. Kaiser built defense city on the dike protected Columbia River flood plain north of Portland, did not embody any special architectural distinction or unique construction technology. Vanport lacked most of the community facilities which were provided in McLoughlin Heights. Vanport's claim to fame was its size and its destruction by the 1948 flood. Vanport's planning and building generated many news stories and magazine features, as did most Kaiser operations, but these stories do not describe any housing breakthroughs. Photographs and descriptions of the building of Vanport show carpenters raising stud framed walls in the conventional manner and tell about the on-site pre cutting and assembly shops, the same as had been developed for Westpark and other projects.

TECHNOLOGY CARRY-OVER INTO POSTWAR HOME BUILDING

The experience with defense preparedness and wartime housing for workers, whether planned for permanent public housing or just for the duration of the war, made many contributions to builders' house design and technology. House building was addressed by larger and more comprehensive builder organizations which built homes with teams of workers doing their specialty in concert and not as a succession of distinct trades moving on and off the job, the 

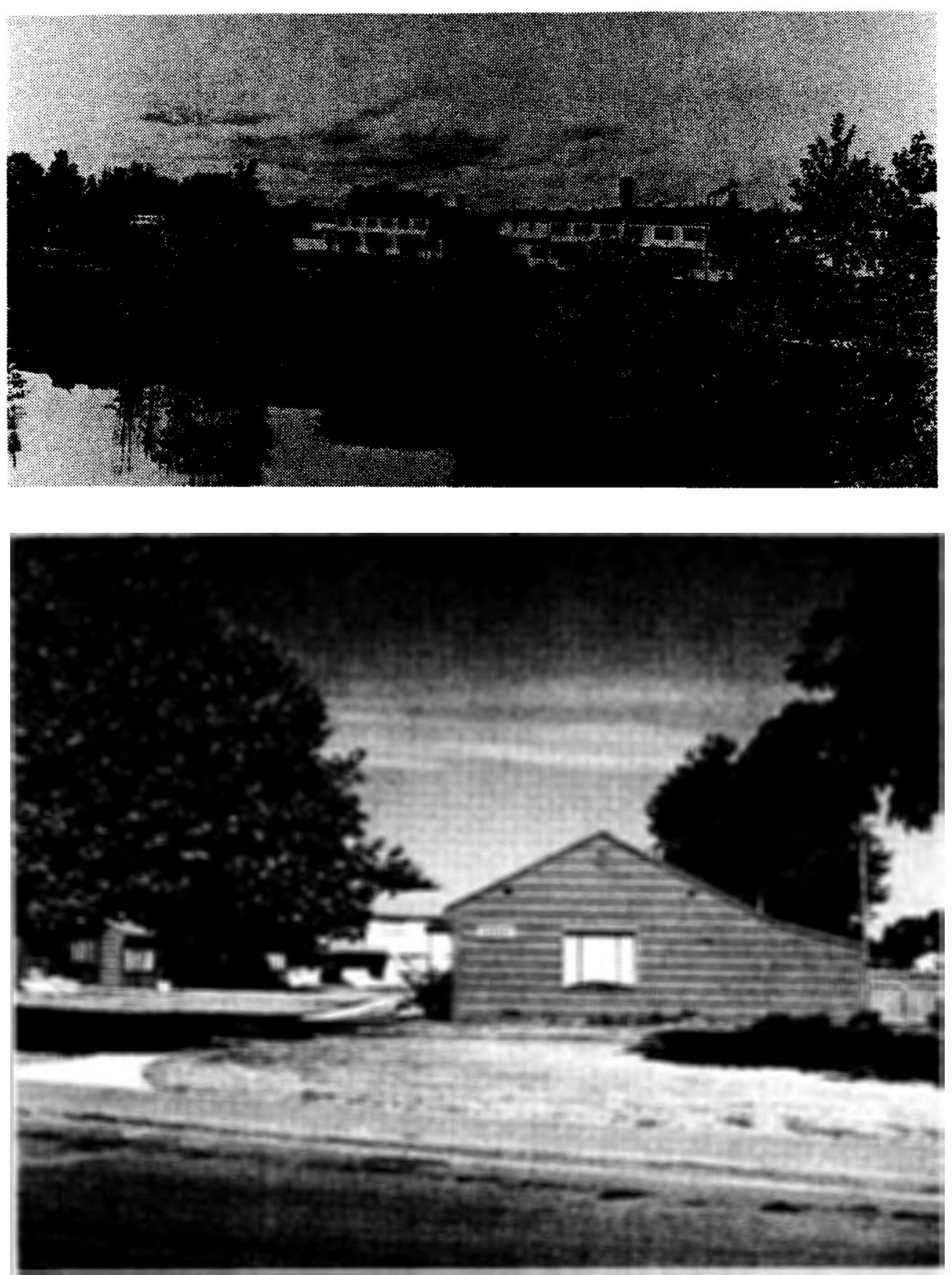

Figure 58. Columbia Villa, Portland, Oregon. 1942 PHA photo, MOMA exhibit, Library of Congress collection. Recent views of University Homes, Portland, 1986. 
precedent for the postwar "merchant builders." Wherever real savings could be realized by a degree of prefabrication or assembly of building elements, not whole buildings, these practices were adopted and labor agreements adjusted to permit the practice. Organized labor had been raised during the war to unprecedented levels of dominance in the building trades; the initial effort of National Recovery Administration in the period from 1933 to 1936 had given union organization a boost, and the mobilization and wartime labor agreements made organized labor the rule not the exception in home building. The concept of planning the small home was changed, multiple use spaces were tested, and the plans were simplified. Wartime exigencies stripped away the vestiges of traditional details and ornament from small home designs and more economical and labor saving finishes were adopted. Wallboards of several kinds replaced more labor intensive plaster on lath. Exterior siding panels were used wherever possible in place of the customary sidings of boards or shingles. Almost all interior moldings were no longer used, and exterior trim was reduced to the barest essentials; eaves no longer would have finished soffits and there are more exposed saw-cut ends than even by bungalow standards. 


\section{POSTWAR HOMES DEMAND AND}

THE HOME BUILDING INDUSTRY

The Veterans' Emergency Housing Program, set forth February 7, 1946, by the Housing Expediter (Wilson W. Wyatt) in his report to the President, calls for the construction of an unprecedented number of moderate and low cost housing accommodations to meet the needs of returning veterans.105

Demobilization in 1945 at the end of World War-II caused an immediate shortage of homes for the returning veterans of the fighting and for war workers shifting to peacetime jobs. Home building had been stopped by the war, production of home building materials had not resumed, and labor in the building industries was disrupted. The government was inclined to stop war production as soon as possible and to close its temporary worker housing facilities. Wherever possible, temporary worker housing units were transferred to local housing authorities to administer and dispose of when no longer needed. Permanent public housing built before and during the war was continued under local control. Private housing in Pacific Northwest cities at the war's end was full to capacity with war workers,

105 "Veterans' Housing Program Order 1. Building Again Regimented," American Builder, April 1946, p. 110. Opening paragraph of article critical of postwar restrictions. 
many of whom would move to other cities but more would remain in their present communities as permanent residents.106 There were no vacancies adequate to absorb the veterans and their families. The conditions at war's end were accurately described by journalist John Keats in The Crack in the Picture Window, an expose of postwar housing problems.107 Keats tells about a fictitious family's experiences living initially in a temporary war housing apartment with its sound transparent walls, vermin, and crowding, and their descent into a succession of suburban GI Bill home-Hells. Both veterans and non veterans who entered universities after the war had the experience of living in the temporary housing units relocated from the shipyards and aircraft factories to campuses faced with expanded postwar enrollments.

The immediate postwar housing conditions were a sharp disappointment to millions of families who had dreamed throughout the war of realizing their expectation of a new

106 Bayard 0. Wheeler, "Housing Needs of the Pacific Northwest...," Pacific Northwest Industry, Aug. 1947 (Seattle: University of Washington), pp. 180-185. Population growth of the Pacific Northwest in Washington and Oregon in 1946 was projected to increase $26.1 \%$ and $15.6 \%$ of the 1940 total assuming that 1940 population was retained and losses because of the war regained. Thirty-eight to forty percent of available housing was rated substandard, and prices were high. Doubling up in available housing is common. A news story in The Oregonian, 27 August 1944, P. 15, tells: "1 of 3 New to Portland, 222,134 Enter City Since April 1940."

107 John Keats, The Crack in the Picture Window (Boston: Houghton Mifflin, Co., 1956). 
home of their own. Government strove to restrain profiteering and inflation in rents and sales prices by extending price and rent controls after the war. On the other hand, the building industry had little incentive to build new houses under controlled conditions when there was an equal or greater demand for new commercial building under fewer restrictions and with generally greater profit margins. In his survey, "Housing Needs of the Pacific Northwest...," Bayard 0. Wheeler found that there was a need for 101,800 additional permanent family dwelling units.108 The housing emergency was still there, although President Truman had appointed a national housing expediter, Wilson $W$. Wyatt, after passage of the Veteran's Emergency Housing Act, and had issued Executive Order 9686 in January 1946 for the stimulation of home building for veterans, a goal of 2.7 million veterans' homes during 1946-1947---"the highest home-building rate in the nation's history." The purpose of the presidential action was to recruit housing workers, develop factory prefabrication, increase insured mortgages amounts to 90 percent, and work for early adoption of the Wagner-Ellender-Taft Housing Bill. Despite these activities, new home building results for 1947 were disappointing, as production actually declined from that in 
1946.109 By almost any measure, the home building industry was in disarray and remained incapable of meeting the demand for new houses for several years.

A year before the war's end, there had been advertisements in the daily papers that some home building and furnishings supplies were available again.110 The popular press resumed its promoting of the ideal single family home and how easily it could be financed. Normal housing demand had built up from the expectations of the Depression years and savings during the war. There was a boom of new families with the cash to spend on down payments and good expectations of regular employment for making monthly house payments, especially if the payments were less than rent payments would be. Normal home demand was further stimulated by the Servicemen's Readjustment Act of 1944, the GI Bill of Rights, which guaranteed private mortgage loans to veterans similar to the FHA program but with additional safeguards for borrowers. Low early monetary 1 imits for any one guaranteed loan kept the GI Bill program from having much impact until 1ater in 1945; but it eventually offered

109 Wheeler, "Housing Needs," pp. 180-185. Sterling F. Green, "Truman Edict Erases Home Building Bars.", The Oregon Journa1, 15 December 1946, p. 1; government permits for new buildings were retained in order to limit the building of luxury type housing. Glenn H. Beyer, Housing: A Factual Analys is (N.Y: The Macmillan Company, 1958), p. 252.

110 "Linoleum Laying Service Now Resumed," advertisement by Lipman-Wolfe department store, Portland, The Oregonian, 27 August 1944, p. 5. 
no down payment, interest below FHA, and the same or longer terms, making that program the preferred one for most first time home buyers. 111

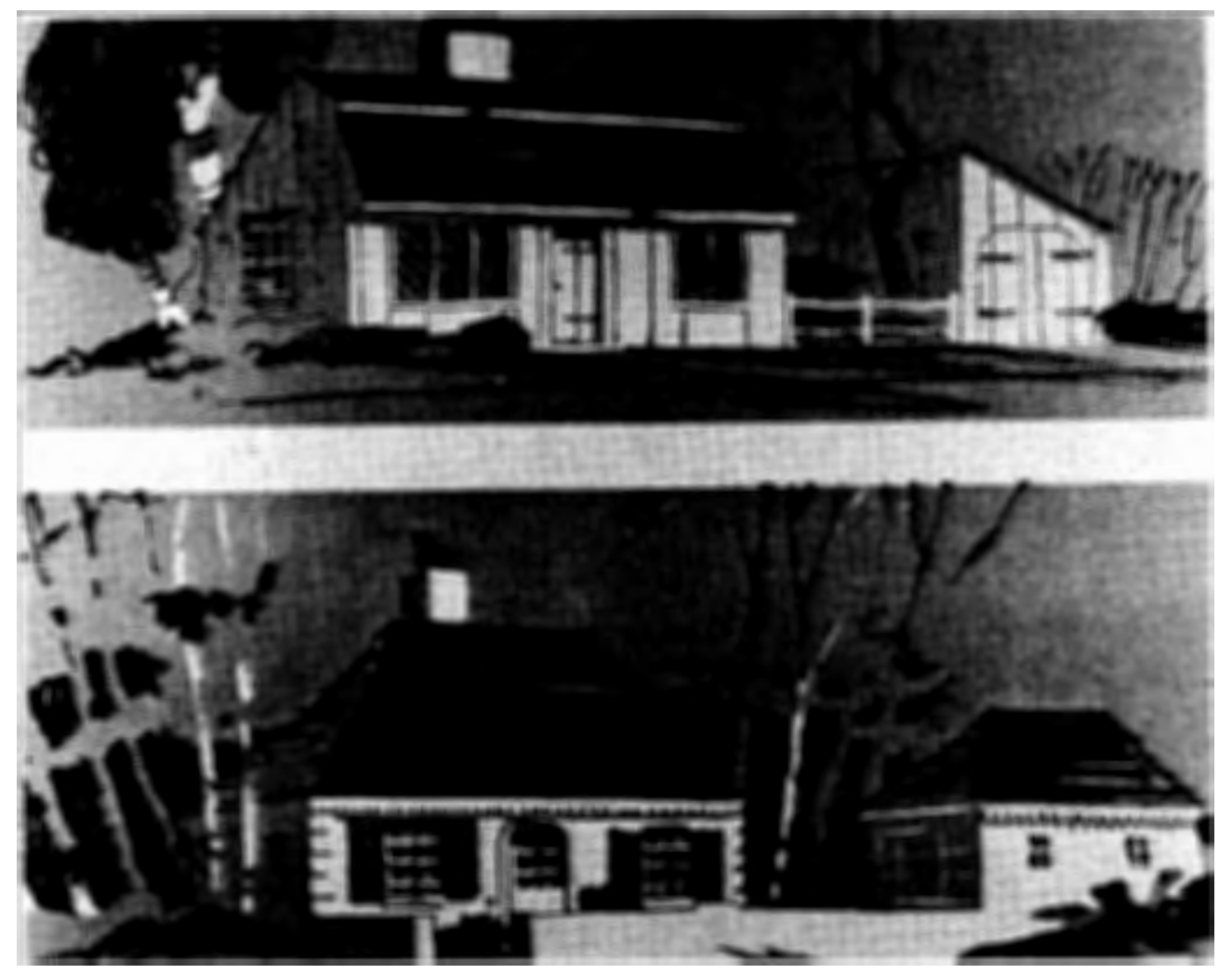

Figure 59. Royal Barry Wills. A Colonial Revival Style house for under $\$ 5,000$., Better Houses for Budgeteers (1941), p. 11. One of three designs on a basic two bedroom plan including one International Modern Style.

Home builder support of postwar housing programs reflected the fundamentally conservative political orientation of most builders and building material suppliers who relented only when the experience with the program or promise in it for private industry support and profits 
changed the program's color. Public housing continued to be damned, but equal help for private home building became acceptable. "The First Battle Won.", thundered the lead headline in Portland Homebuilder, 29 September 1945, the journal of the Home Builders Association of Metropolitan Portland, then known as Portland Home Builders Association: "Al1 controls on home building will be lifted 15 October 1945....a step toward the American way of 1 ife."; and the program was a ".socialistic, impractical, billion dollar public housing scheme.", referring to the Wagner-Ellender Public Housing Bill being debated then in the Senate. The Home Builder wrote that the Public Housing Bill was "...a wild spending spree.", while the veteran's housing bill was supported. The editorial concluded by saying that there was no housing available through the Portland Housing Authority office and the veteran, "He is tired of barracks life." His family..." will want attractive low-priced places with green lawns and sheltering trees."112

The National Home Builders Association President Joseph E. Merrion addressed his organization regarding the Wagner-Ellender Housing Bill. He said that the home building industry could supply 4.5 million new jobs once industry is freed from controls, and continued:

112 Home Builders Association of Metropolitan Portland, The Portland Home Builder, Vol. 1, August-October 1945; and Oregon Journal, guest editorial: "Not Federal Housing Projects," 3 August 1945. 
The need for homes is nationwide and that need must and will be met. $\$ 178$ billion is in private savings and home-hungry people are ready to use it for building, for furnishings and other necessities and comforts of life. The builders of this nation are ready to go but the OPA (Office of Price Administration), aided by the CIO (labor union), is still attempting to place controls on the price of lots, services, materials and the finished product.

Merrion continued in the same vein to link the government to European influences and bureaucracy, and he called the Wagner-Ellender bill socialistic.

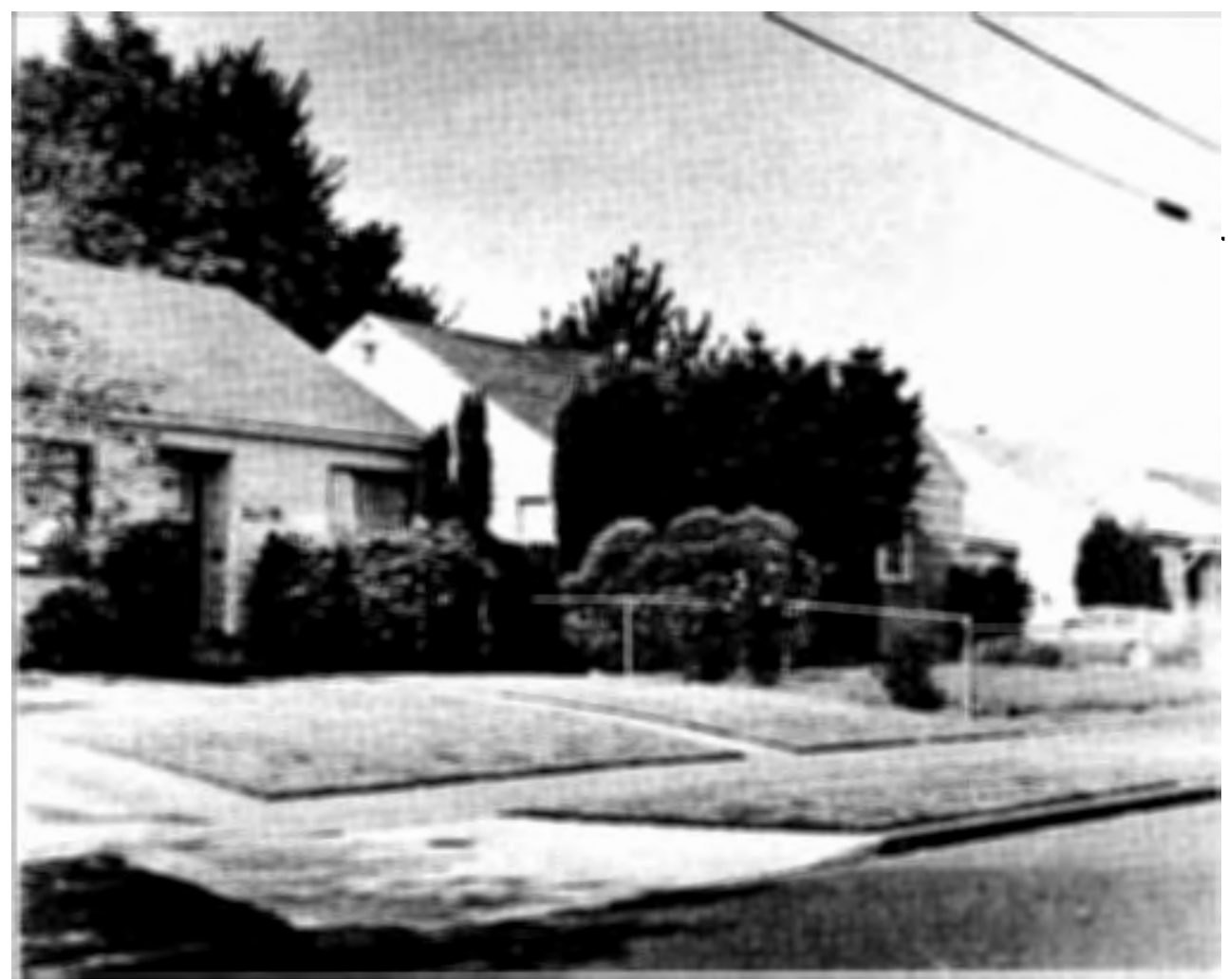

Figure 60. GI Homes all in a row. SE Portland. 

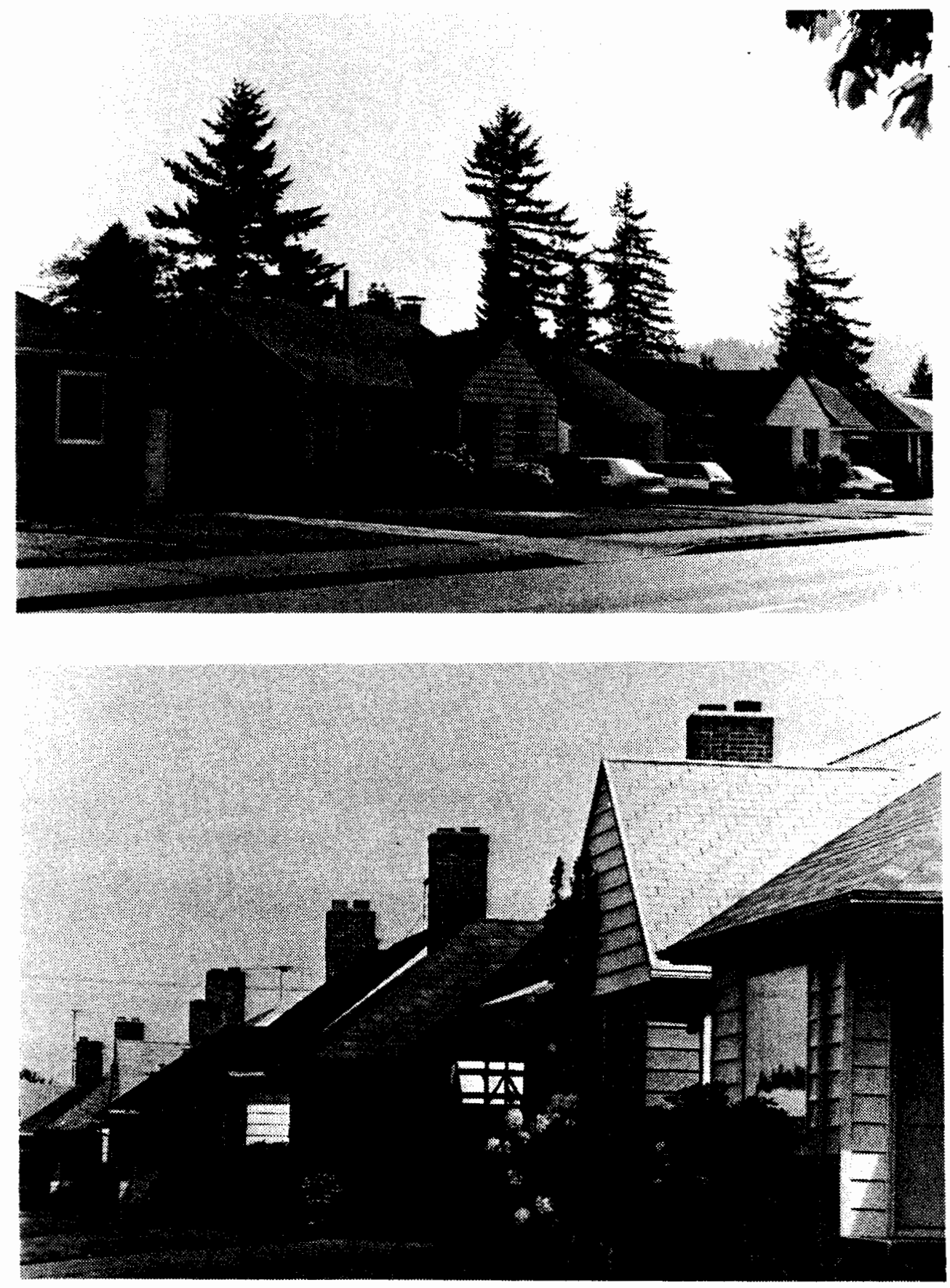

Figure 61. Asbahr Homes' development in Port1and. Ted Asbahr was one of Portland's largest early postwar home builders but far smaller than any of the Merchant Builders. SE Stark and Madison streets east of $82 \mathrm{nd}$ Avenue. 
The popular ideals for housing remained unshaken. The unrealized promise of mass produced homes, priced like automobiles but presumably not yet an expendable consumer commodity (although disposable paper houses were sometimes mentioned), continued to fire the imaginations of theorists and architects. Futurist Buckminster Fuller's "Dymaxion" dream houses were invoked as before; but, little was accomplished as the home shortage continued. One commentator concluded that, "We do not have a housing industry at a11."113

SOME PROGRESS IN MEETING THE HOUSING NEED

Three years after war's end, some home building progress was being made, but government and industry still reported failures to meet annual building forecasts or to begin to meet the demand for new homes. American Builder magazine reported a scattered and unfocused pattern of new home construction and home building innovations: 500 unit developments started, expanded apprentice programs and training in systematic building efficiency, "Homes you can build for veterans," and "Reconversion Housing."

Because of the need for homes, there was a resurgence of do-it-yourself home building information similar to some

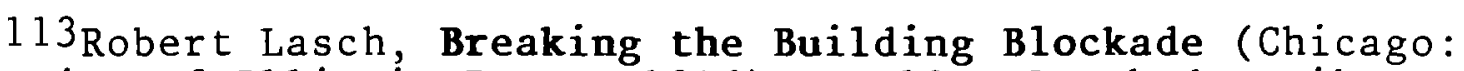
University of Illinois Press, 1946), p. 10. Lasch describes a boom-bust theme and advocates a high-tech solution to meeting the need for housing. 
of the home building feature stories and programs in the Depression. Many veterans built their own log cabin homes if they had access to acreage and pole size trees or chose to use one of the pre-cut $\log$ house systems being marketed (as now). New and reprinted information on building with adobe and pisé de terre appeared. A pisé house in Portland's west hills was reported about 1950.114

In an open letter to the average married war veteran the home building industry explained its side of the failure to meet expectations. "The Nation's Home Builders Tell Sergeant Brown the Truth," tells this ex-soldier, his wife and infant daughter, that home builders are anxious to build for them, but homes are not made like automobiles, shirts, or radios. The government underbuilt housing during the war and was delaying 1 ifting restrictions, the industry was being regulated to death. The home building industry was hampered by labor strikes and inadequate materials supplies--some 20 critical materials were in very limited supply with black markets existing for others. President Truman had recognized the housing emergency and had appointed a new national housing expediter, Wilson $W$. Wyatt, who promised to facilitate material allocations for housing and cut through restrictions. The goal of $2.5 \mathrm{mill}$ ion homes in 1946 and

$114 \mathrm{M}$. R. Harrington, How to Build a California Adobe (Los Angeles: Ward Ritchie Press and Southwest Museum, 1948). This book is one of many available. Unfortunately, the newspaper feature of the pise home has eluded me. 
1947 was not realized, nor were the expectations for prefabrication. New government approvals of materials and systems were a help, but there was reluctance by conventional builders to adopting new methods. The industrial and commercial building sector was booming, adding to the labor shortage for home building; and training needs in building trades were not being met. However, the home builders' open letter continued, "Private enterprise can do the job...only by this means can you get the kind of home you dreamed of during those terrible days on that island in the South Pacific."l15

"We drink a little, smoke a little, and have a baby; isn't there a landlord who's half human, maybe?", ran one classified advertisement by a home seeker. The prospective tenant offered to post a bond or pay a $\$ 1,000$. damage deposit; but there were not enough homes available on any terms. Meanwhile, the Housing Authority of Portland had 700 on its waiting 1 ist at the same time as 236 Guilds Lake Court wartime units were being razed for industrial development. 116

115Frank W. Cortright, "The Nation's Home Builders Tell Sergeant Brown the Truth," American Builder, July 1948, Pp. 84-85.

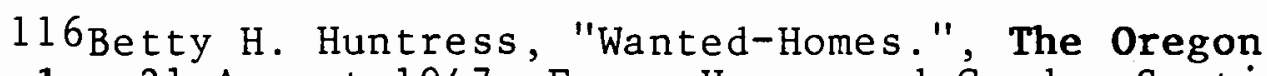
Journa1, 31 August 1947, Farm, Home, and Garden Section, p. 6 . 
INDUSTRY CHANGES IN POSTWAR BUILDERS' HOUSES

The home building industry was a very different organism after World War-II. The small independent house builder continued his general practices, but he was joined by the emergence of the "merchant builders," large corporate builders who dealt in large subdivision tracts, undertook to build thousands of houses for speculative sale instead of two or three at one time, and who employed every labor and material saving advantage that they found to be effective in keeping costs low and profit margins adequate. Labor in the postwar home building industry was predominantly unionized for the large builders, and each craft fought to protect its customary work and also to expand its jurisdiction over new materials and methods developments. Industrialized building and prefabrication was tried in many degrees, from manufacturing single component home parts and systems assemblies to totally integrated factory prefabricated homes for assembly on site. New materials which offered lower costs, easier installation savings, or just the appearance of being the latest thing were plentiful, heavily promoted, and tried just about everywhere.

The organization of the small independent home building contractors which had begun iust bofore the United States entered World War-II grew rapidly into an expanded business deveiopment, lobbying, self educaticn, marketing, and consumer information and education organization. Hone 
shows, begun just before the war, became annual events which filled exhibition halls with displays of products and services and one or more model houses, and the annual model home tours were begun. The new home market was correctly seen as offering almost unlimited opportunity for sales of new homes and all the related equipment, appliances, furnishings, decorator services, and landscaping. The American dream of one's own home now seemed achievable, or so the home industry and government told us. Portland home shows began in 1948 and have been annual spring events

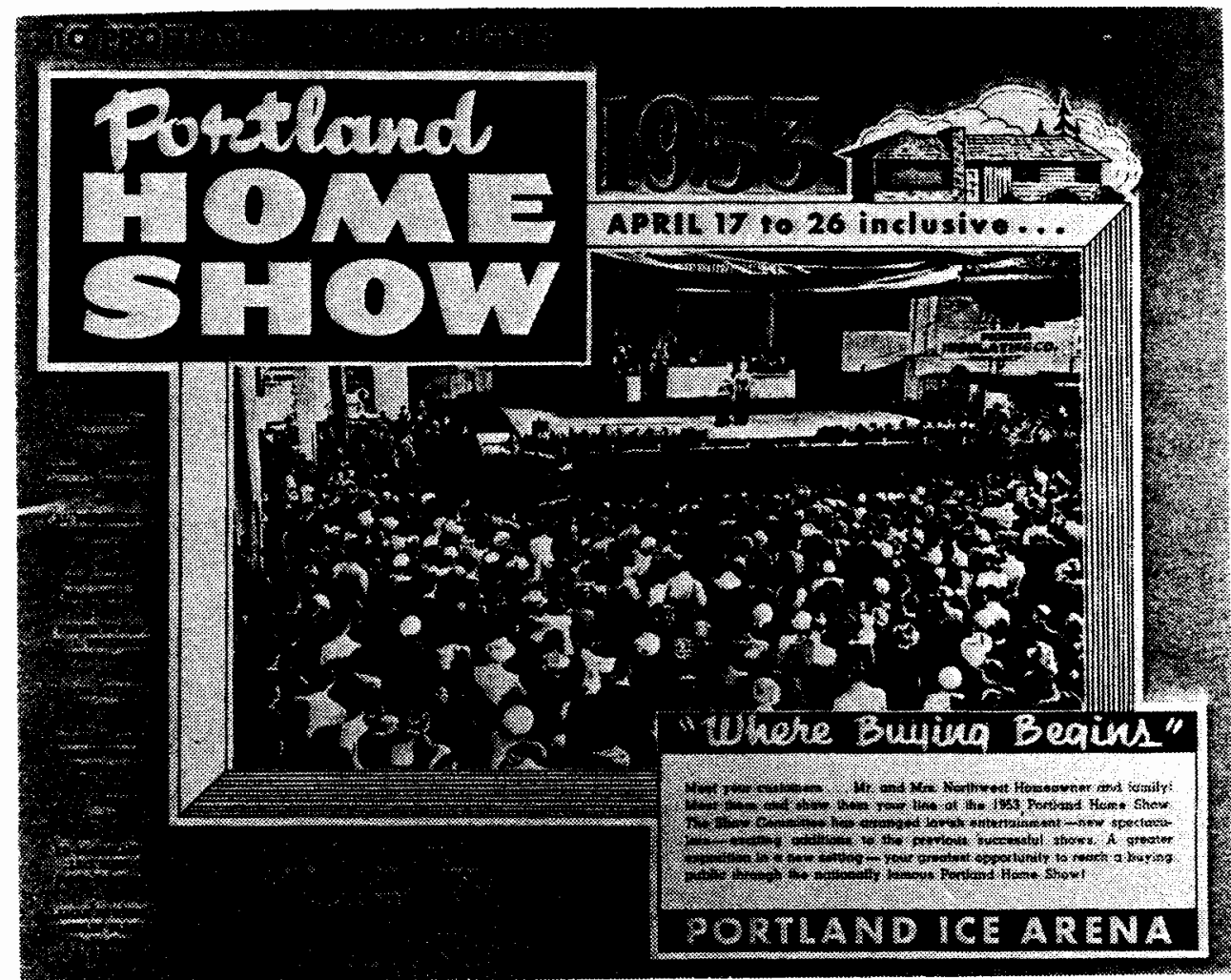

Figure 62. Promotion for the 1953 Home Show held in the old Ice Arena in Northwest Portland. HBAMP files. 
ever since. The first one was held in the Ice Arena in Northwest Portland on NW Marshall Street between 20 th and 21 st Avenues. Subsequent ones were held in the Pacific International Livestock Exposition Buildings on North Marine Drive, now the Multnomah County Exposition Center, with the 1953 show again held in the Ice Arena. Each show featured new products and modern living ideas.

\section{HOME BUILDING LABOR}

The construction industry crafts unions had almost totally organized the available workers during the war and in the immediate demobilization period. Faced with an overwhelming demand for new homes, builders were in no position to negotiate for lower wages and changes in customary crafts practices and jurisdictions. Except for a brief drop in wages due to the transition from war industries to private building, the home building trades enjoyed a steadily rising trend in wages and an almost complete control over work rules. The boom in home construction which built from the slow 1945-6 beginnings especially favored the trade unions and sustained both contractors and union members for almost thirty postwar years. 117

But, the strength of union organization and influence

117Wollner, The City Builders, pp. 121-125. Beyer, Housing, PP. 88-95. 
on home building artificially added to the rise in prices and to slowing any turn toward industrialization and prefabrication of house building by builders unless among the very largest ones. Unions maintained strict control over the available supply of their craftsmen and the entry of apprentices, over work rules, and over the introduction of labor saving new materials and methods. The arguments
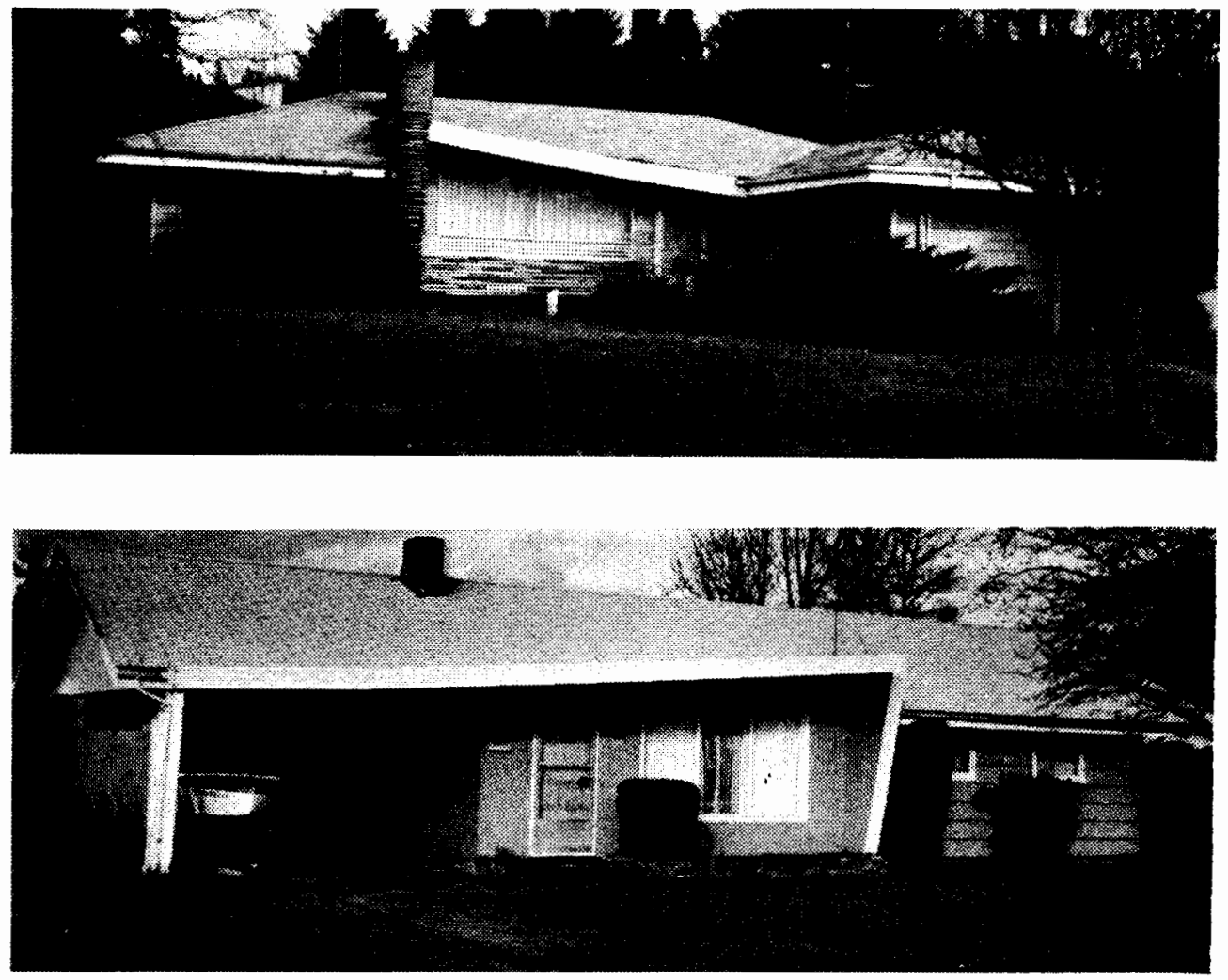

Figure 63. Lindberg Homes development, South Eugene, c.1948. The Modern Ranch Style with a tail fin and Easter egg colors.

against innovations in customary practices always referred to the need for traditional quality---public health, welfare, and safety, but the effect was to make the adoption of improved building materials and systems very slow if such 
adoption was seen as presenting a reduction in labor utilization or the elimination of a customary step in the building process.

The production of building materials also was affected by organized labor's gains during the war years. The production of building materials from the forests and mills to the factories was largely unionized during the New Deal and by government's influences during the war. The demand for materials for all levels of construction after the war and during the Korean "police action" meant that production rose swiftly after the initial demobilization let-down to reach a level of maximum production in 1948 which had not been equaled since before the Depression. Under such conditions of full employment and maximum production, building material costs rose.

\section{THE RISE OF THE MERCHANT BUILDERS}

The emergence of the merchant builders was a phenomenon of the postwar years which diminished as the need for new homes for a very large number of an essentially uniform class of buyer's demands was met in the 1970s. The merchant builders were a product of wartime mobilization and experience with the mass production of an essentially uniform product whether weapons or houses. 

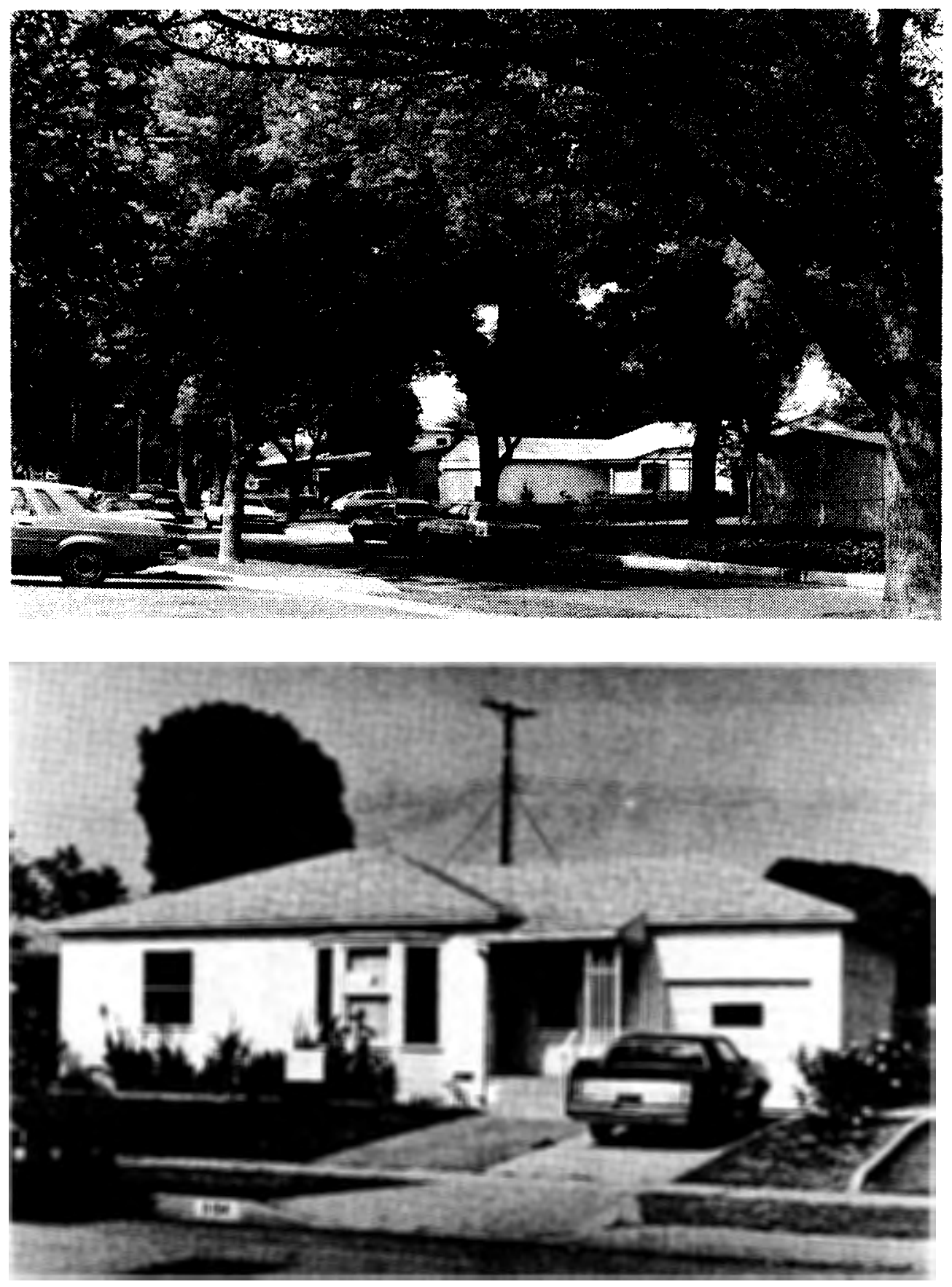

Figure 64. Kaiser's Panorama City, Los Angeles, California. Streetscape and one of the typical houses. 
Henry J. Kaiser's Kaiser Community Homes was a partnership with builder Fritz J. Burns "...for the purpose of building low-cost homes on a national scale." Plans were made for 100 houses per week at several west coast sites and in Willow Run, Michigan; but the bulk of building was done in the Los Angeles area and the midwest.118 Kaiser took its defense housing experiencè, ship building experience, and prewar heavy construction experience and applied it immediately after the war to home building. Kaiser did not perfect a prefabricated house despite some experiments, but did build some of the largest new homes developments ever built at Willow Run, Michigan, and near Los Angeles, California. At Kaiser's Panorama City, near Los Angeles, over 3,000 uniform low-cost homes were built in a single development of curving streets not far from Kaiser's industries.

Kaiser continued its support of multi-faceted community services, such as Permanente medical services, which were near to the new "city." The Panorama City homes are basically conventionally built houses but which were built by the same on-site pre-cutting and pre-assembly practices developed at Vanport and Westpark at the beginning of the war. The Panorama City houses are one story Modern Colonial Ranch Style homes: two bedrooms predominate, a garage, and

118 American Builder, November 1948, pp. 95-97. This article is a report on Kaiser's building plans and the intention to produce 100 houses per week. 
5,000 square foot lots with fruit trees, a type of house which might have been built anywhere in the country from the same plans.

Kaiser also continued its wartime practices of working with the labor unions to maintain the prevailing wage scale and accommodate union work rules to the semi prefabrication of homes; its contract with the AFofL provided for wage rates averaging $\$ 1.50$ per hour for a 45-hour week and for remanufacturing of lumber in its own shops and for other

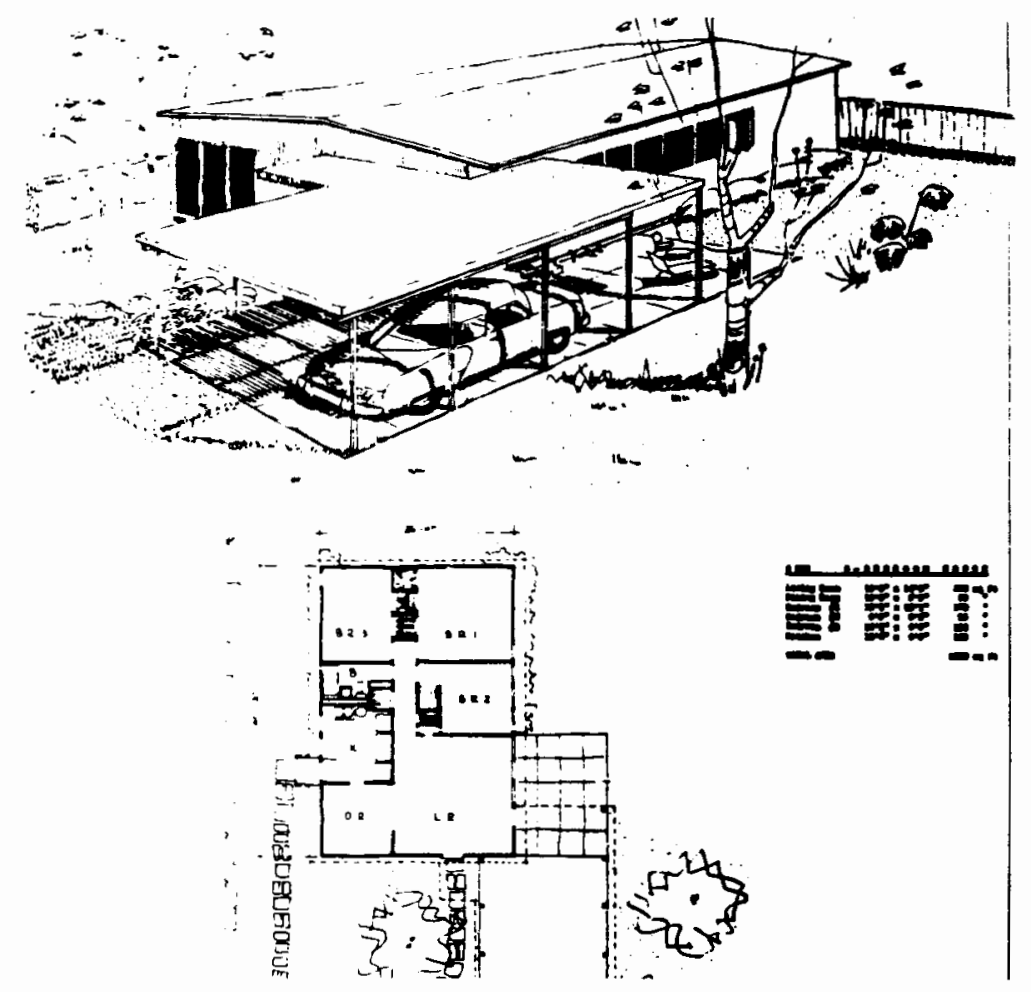

Figure 65. Advertising brochure illustrations for the General Panel Homes. From Gilbert, The Dream.

pre-assembly. Panorama City today is a fairly successful neighborhood of lower middle class homes, in generally good repair and maintenance, many enlarged and remodeled, but 
still essentially as originally built. A typical Panorama City home which cost about $\$ 7,000$. when new now sells for $\$ 93,000$.

One of the most ambitious attempts to meet the postwar housing need by prefabrication was that program developed from the European experience by architects Walter Gropius and Konrad Wachsmann. Gropius was instrumental in bringing Wachsman to the United States ahead of the war and in launching him into the American homes market. The two had worked together to plan several models of prefabricated home systems. The postwar housing demand seemed to offer an ideal climate in which to develop the experimental models

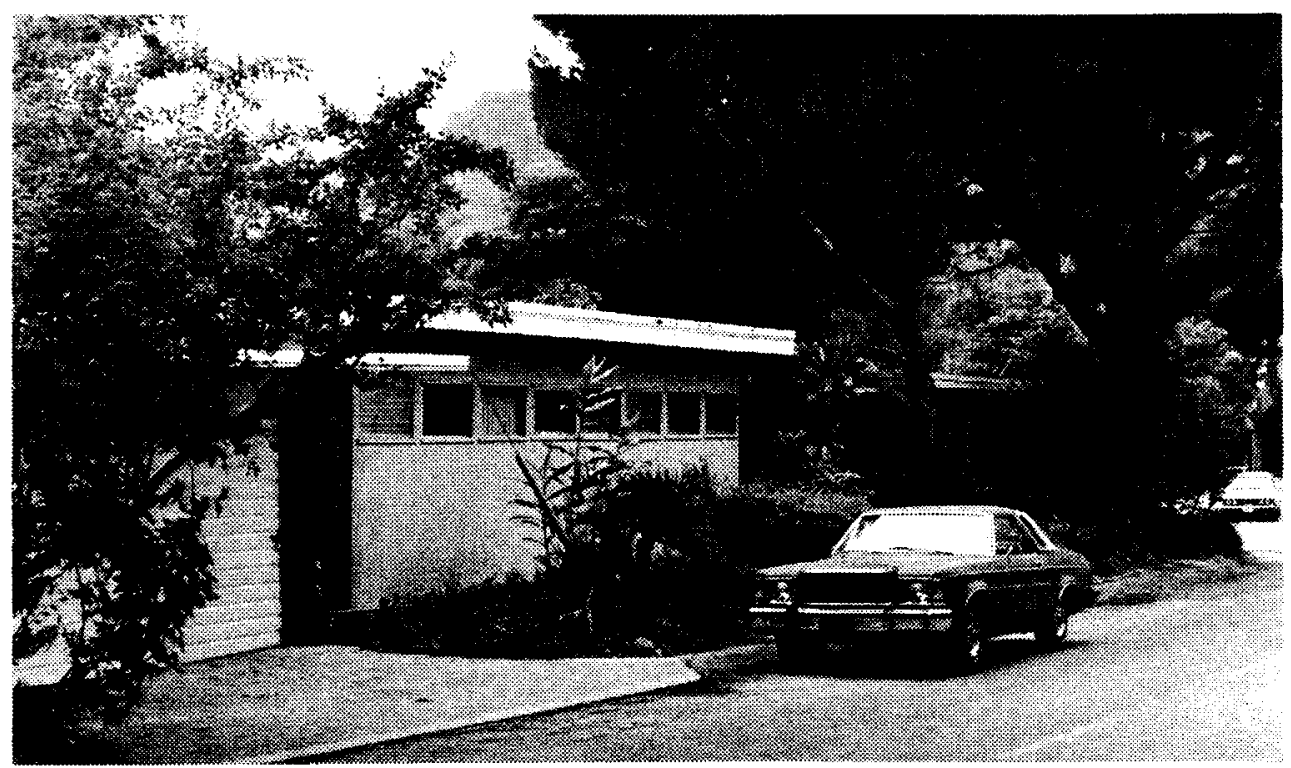

Figure 66. The Rudy Wolf House, Hollywood, 1947. The exterior has been covered with stucco which obscures the nature of the panelized construction. The Wolf House is believed to be the only remaining example. 
into full production. Wachsmann's association with the General Panel Corporation, Burbank, California, developed the theoretical building system into a marketable building system by 1946 . The General Panel homes clearly show their International Modern Style heritage and even appear in many ways to resemble the model homes planned by the University of Illinois' Small Homes Council and some of the Weyerhaeuser Company Tim-Bo-Loc and modular system details. The houses were generally considered to be well made and successful, except that they could not compete with conventionally built houses, and General Panel Corporation was never financially sound. The project and General Panel Corporation were ended in 1950.119

The merchant builders, Henry J. Kaiser, Eichler Homes, Klingbeil Company, Victor Palmieri \& Company, Levitt \& Sons, and others made the greatest progress in approaching the building of homes on an industrialized basis but without ever achieving true factory or prefabricated production. Prefabrication never became a fact in substantially meeting the need for low-cost homes. When a prefabricated house must be transported to the site and must still be site assembled, there is a potential for making savings in only one-half of the total building cost, the rest is unavoidable 
site work.120 The major labor innovation of the merchant builders was the change to trained crew-teams repeating the same activities on each site instead of the individual craftsman doing his specialty in isolation for each building. Standardization not prefabrication was the key.

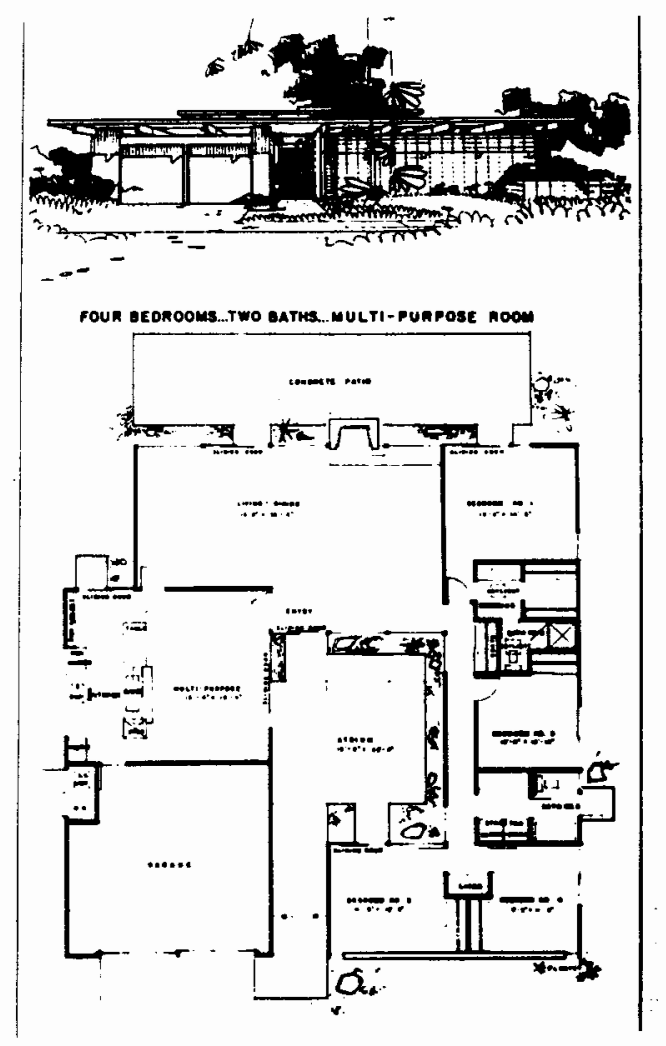

Figure 67. Plan for an Eichler Home. Wright, Building the Dream.

The merchant builder organizations were vertical not horizontal; all elements of the projects were centered within the one company from site development and design to closing with the buyers and financing---or at least coor-

120 Carl C. Strandberg, President of Lustron Homes and a panel ist, "A Life Roundtable on Housing," Life, 31 January 1949, pp. 72-86. 
dination of all elements when either design or financing were found outside the company. In comparison with the traditional small home builder who builds less than fifty, often only a few houses per year, the merchant builders scheduled to build thousands of units yearly, and themselves grew in an ad-hoc manner to meet their needs as they arose. There was no plan for how they should be constituted. The successful ones lasted throughout the boom, many failed. They did everything possible themselves, a very entrepreneurial process.

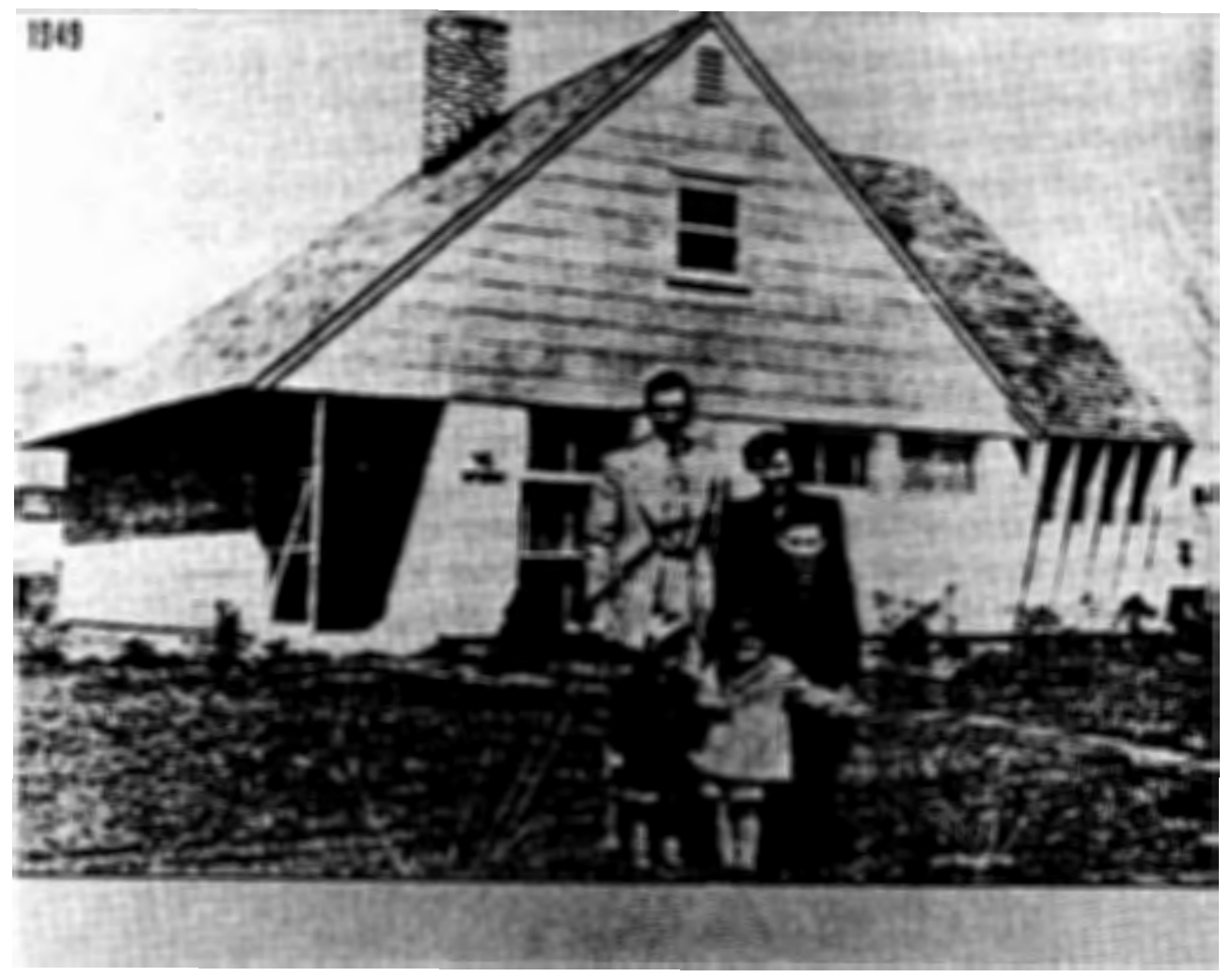

Figure 68. Levittown, Pennsylvania. One of the typical houses. Wright, Building the Dream, from Life. 
William J. Levitt honed his housing development skills while serving as a Navy Lieutenant in World War-II. He developed housing for 2,500 workers at Norfolk, Virginia, and following that, built installations in service with the Seabees in the Pacific. After the war, in 1946, he built 1,000 veterans' homes units in Roslyn, Long Island, "... in spite of the $i 11$ conceived Wyatt program..."12l Despite a popular perception of Levittown's being symbolic of the worst of postwar suburban living, Levittown has matured pretty well, now appearing much 1 ike any older settled residential neighborhood; the spindly trees of 1948 have matured into tree lined avenues which conceal the immense size of the development and which soften the profiles of so many similar houses. The houses themselves have been remodeled, added to, and otherwise personalized so that their sameness is no longer obvious. Undoubtedly, owners have improved many of the original economical interior building and finishing systems.

When the mass housing builders used the skills of major architects to design their homes product, the resulting homes developments were not at all unattractive in the beginning, and many became upper middle class neighborhoods. Eichler Homes' California Modern Style homes were remarkable both for their good value through economical design and for

121 "Levitt \&.Sons Complete Veterans' Project ' ... in spite of Wyatt Program." American Builder, December 1948, pp. $72-77,154$. 
their suitability to California living: openness, multiple use spaces, and careful planning for privacy toward the street and access to the garden in back. Where Levitt's houses were based on traditional styles, Eichler adopted an atrium style home designed by Robert Anshen and relied heavily on the creativity of other well known architects. 122

"The Devil is the house.", said one of the panelists on the Life roundtable, "The average American has been encouraged by the age in which he lives to believe that his dream of a low-cost house of his own can and ought to be realized."123

"Owning a single-family home is so much a part of the American middle-class life-style that we have come to take it for granted," said Ned Eichler about the impetus behind the housing demand which made the merchant builder organizations possible. These large corporate home builders were a direct response to the availability of government guaranteed home loans to meet the demands of the new families and postwar growth. "Only in the late 1940 s did a majority of families become owners rather than renters. By 1950, 55 percent were homeowners; by 1960,62 percent; and by the late 1970s two-thirds of American families owned their homes."124 Home builders honestly sought to meet the public's expectations.

122 Ned Eichler, The Merchant Builders (Cambridge; MIT Press, 1982), pp. 86,87.

123Life magazine, 31 January 1949, pp. 72-86.

124 Eichler, Merchant Builders, pp. vii, viii. 
Other factors also contributed to the number and kinds of homes built in these city size developments, availability of public and other low-cost electric power to run new home equipment and for easy to install electric heat, acceptance of new materials and building methods by the public, building code enforcers, and mortgage insurers, and the adoption of innovative financing means as elements in the development of a mass housing industry.

\section{NEW HOME BUILDING SYSTEMS AND PRODUCTS}

The study and development of new materials for home building and new home plans and systems for building benefitted directly from the demand for homes and the government and industries' efforts to meet that demand. The Housing and Home Finance Agency, successor to the National Housing Administration created by the Housing Act of 1948, contracted for housing research with several government and institutional organizations, seeking answers to the questions of planning and building modern, healthful, low-cost homes. The private building materials industries and trade associations also invested in studies of new product development, new building systems, and the promotion of developed innovations.

The early postwar FHA Minimum Property Requirements reflected the slow beginnings of the program before the war and its interruption. The 1947 Requirements were a thin 

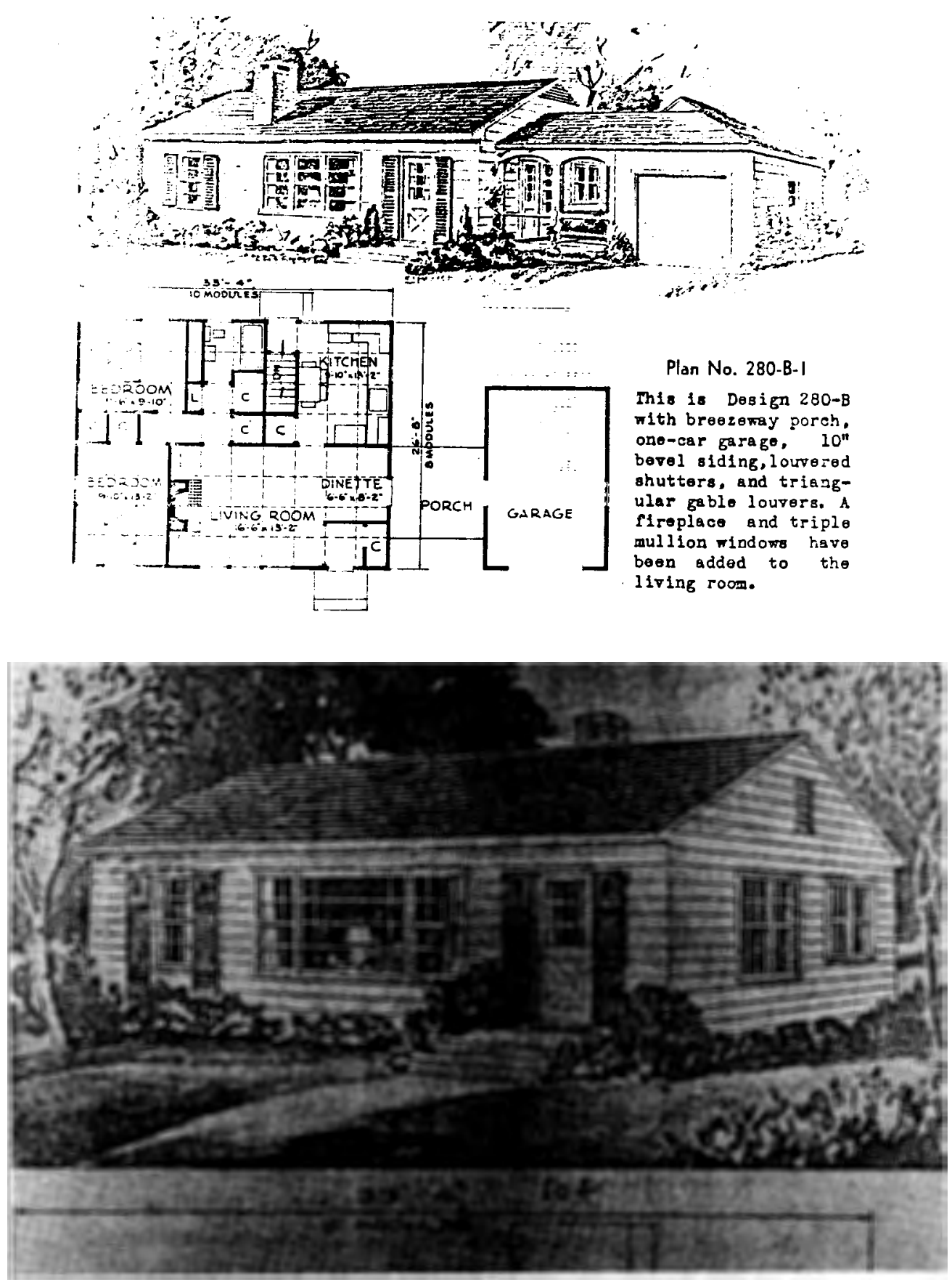

Figure 69. Weyerhaeuser Modular House views and details, 1948. Weyerhaeuser Archive. 
booklet of mostly outline specifications for planning and building standards to be met by houses eligible for mortgage insurance. The construction materials and methods described are very conventional, but provided for new materials and methods' use when "...satisfactory to the Chief Underwriter."

The Weyerhaeuser Company's General Timber Service, Inc., Fabricating Division, Dubuque, Iowa, applied to the Chief Underwriter for approval of its prefabricated house unit system and received approval in Bulletin No. SE-81, 2 March 1948, for a "Special Method of Construction: Shop Fabricated Wood Frame Unit Construction for the Weyerhaeuser Modular House." The Weyerhaeuser house system is an example of postwar modular designing and shop fabrication of standard building panels for floors, walls, and roofs which could be assembled into a variety of house sizes and configurations. Weyerhaeuser offered a catalog of standard plans, but these could be varied to suit the needs of any one owner within the limits of the 40 inch plan module.

Prefabrication of sub assemblies for homes was another alternative. The Mobilecore packaged utilities unit was an example of one such factory made assembly. This unit consisted of an $8 \times 24 \times 9$ foot size integrated kitchen, bathroom, laundry, and water and space heating equipment core designed to be transported to the building site and placed within the framework of the house. Mobilecore 
factories were located in Portland, Oregon, and Trenton, New Jersey. The Portland operations were an adjunct of Timber Structures, Incorporated, at the Guild's Lake plant site.125 Systematized modular designing, usually based on a four inch module but sometimes on larger multiples of four inches, had originated in the European efforts to industrialize housing production (a four inch module is roughly equivalent to a ten centimeter increment). For about ten years after World War-II, modular designing was taught and sometimes practiced in architecture and by material manufacturers. Modular design standards appear only in the fourth and fifth editions of Architectural Graphics Standards, not before and not after. As the promises of prefabrication faded so did interest in modular designing---although it remains in fashion in. Europe and other parts of the metric world.126 Modular designing was concurrent with interest in solar heating and natural daylighting and ventilation, all of which disappeared from the architectural vocabulary until the recent energy crisis. These were industry standards and programs and were not addressed directly by FHA.

${ }^{125}$ American Builder, December 1948, pp. 94-95. There was no information on how many of these units were manufactured or where installed, but undoubtedly some may remain, at least in the Portland or Trenton vicinities.

126 Charles George Ramsey and Harold Reeve Sleeper, Architectural Graphics Standards, 5 th ed. (N.Y: John Wiley \& Sons, Inc., 1966), Pp. 289-291, 297, 670-673. 


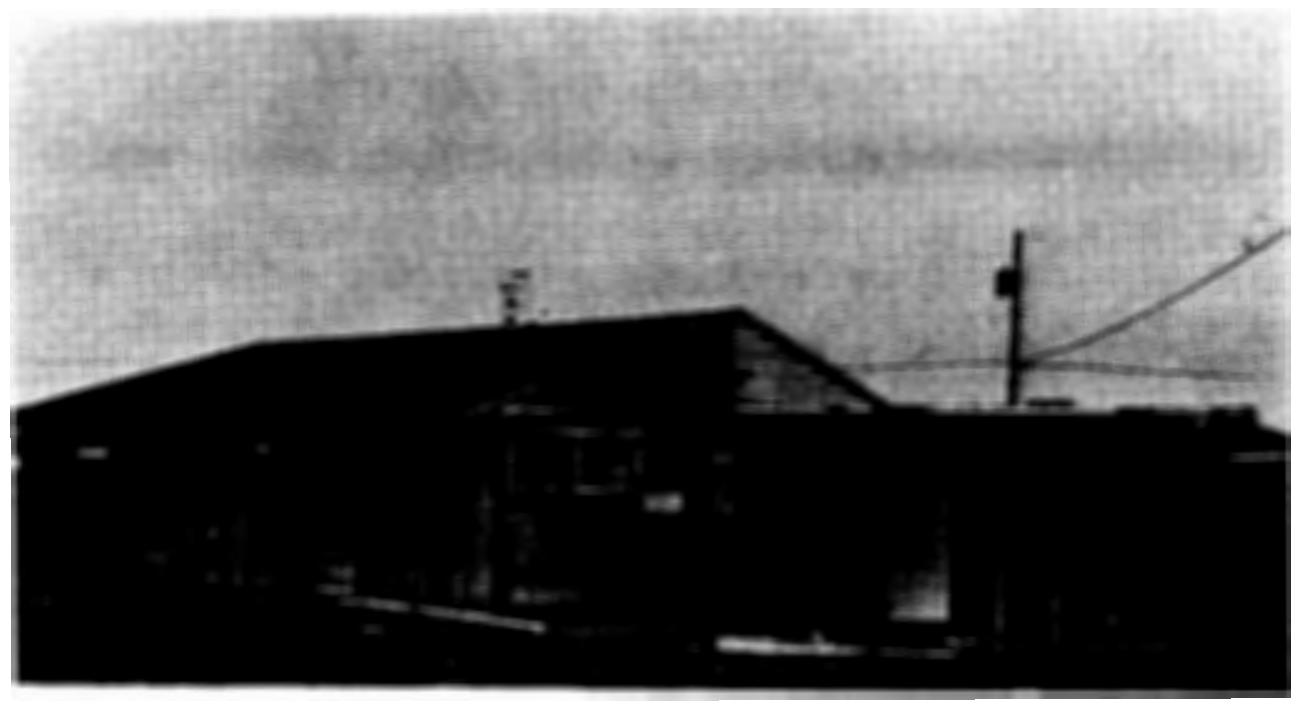

HCUSE "An

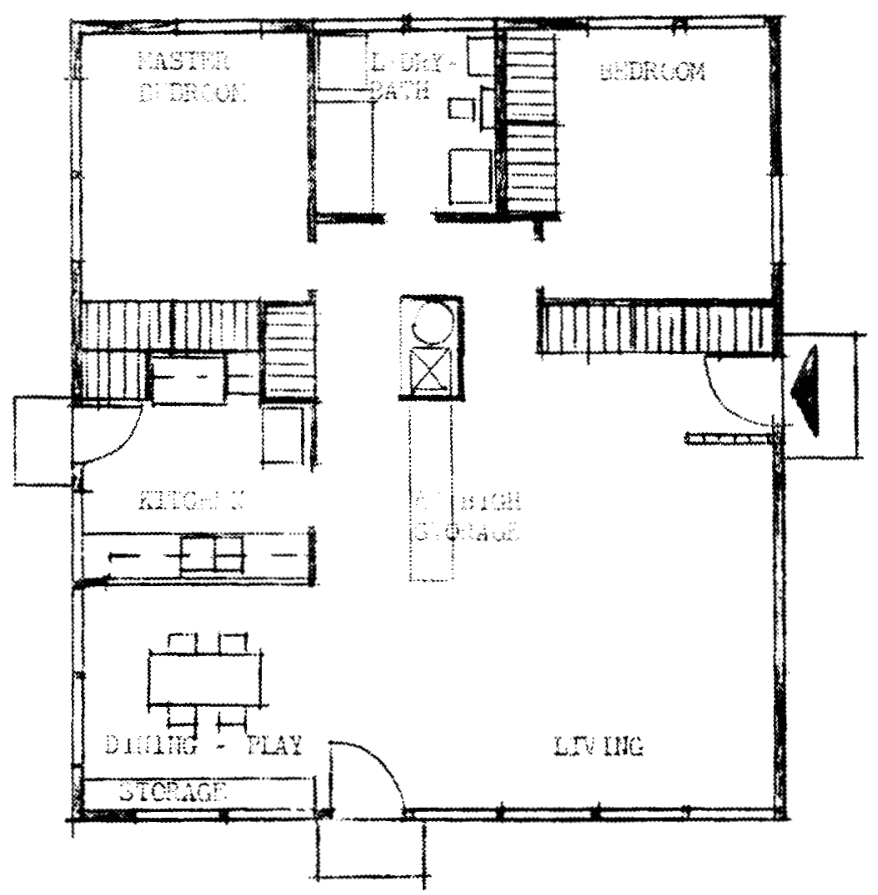

Figure 70. Examples of home building planning by the Small Homes Council. SHC library collection, University of Illinois. 
Weyerhaeuser was not alone in developing and promoting new products as well as its old ones. Popular and trade magazines and the daily newspapers, especially in the feature home sections, carried many columns and pages of home products advertising. The dream home, for example, was shown decorated with coats of Dutch Boy Paint, with Kohler bathrooms, American Kitchens, and General Electric appliances. No product or system applicable to home building was omitted.

The variety and competition present in the face of a large and undiscriminating demand for homes allowed many faulty materials and poor building practices to pass by the FHA standards and to be overlooked by VA's more 1 iberal self policing inspection. The early problems apparently caught the FHA unprepared and prompted its research efforts. Most of the postwar housing research was done by contract with the University of Illinois' Small Homes Council, Champaign, Illinois. A succession of studies were made which resulted in publications on the results and revised FHA guidelines and standards. The Small Homes Council studies begin in 1948 and continue through 1960. The subjects range from space planning in small homes' designing, through economy studies of wood framing applications, to recommendations on problem abandoned, repossessed, and vacant FHA insured homes 
and their deficiencies. 127

The effect of the commissioned studies and of industry research requests for approval of new materials and methods was to build the base of information needed to produce major revisions to the Minimum Property Standards, in 1952 and again in 1966, including interim revisions. Each revision incorporated the guidelines and interim standards produced by the research and experience with the program. The FHA Minimum Property Standards had become one of the most comprehensive and widely applied design and building codes for single family housing, more detailed and especially designed to insure better building practices than were required by many local and national standard codes then in use. Only the three major standard building codes which were growing in acceptance approached the detail of the FHA standard. The fourth standard code, the National Board of Fire Underwriters' National Building Code, once predominant but now no longer used, hardly applied at all to good home building practices. As a recognized standard for homes design and construction, the FHA Standards were adopted with modifications for building government housing for the

127 Smal1 Homes Council, University of Illinois, Champaign, Illinois. Notes made from loaned library copies, research papers, homes research publications, and correspondence. 
military and other public service workers. 128 Construction of Permanent Family Housing for Federal Personnel (Washington: Government Printing office, 1953). 
CHAPTER VIII

THE POSTWAR LOW-COST DREAM HOUSE

Little boxes on the hillside, little boxes made of ticky-tacky, 1ittle boxes on the hillside, little boxes all the same. There's a green one and a pink one and a blue one and a yellow one, and they're all made out of ticky-tacky and they all look just the same. 129

Malvina Reynolds' popular song may have been inspired by row houses on the Daly City, California, hillside, but it only echoed the common perception that low-cost home building after the war had been a colossal failure. Disappointment in reaching the dream of the private home for all brought the whole premiss of the dream into question: should low and low middle income families be encouraged to buy private homes or should they be content with apartments and rented houses, can the American homes industry ever meet the expectations, and is small home ownership just another means of stripping the meager wealth from low and moderate income families? The spread of homes into the suburbs seemed inevitable, but the new communities failed to function adequately and were soon becoming burdens to the

129Malvina Reynolds, "Little Boxes" (1962), The Malvina Reynolds Songbook (Berkeley: Schroder Music Company, 1974). 
structure of the larger community. There was a nostalgia for the old style family homes and simpler times.130

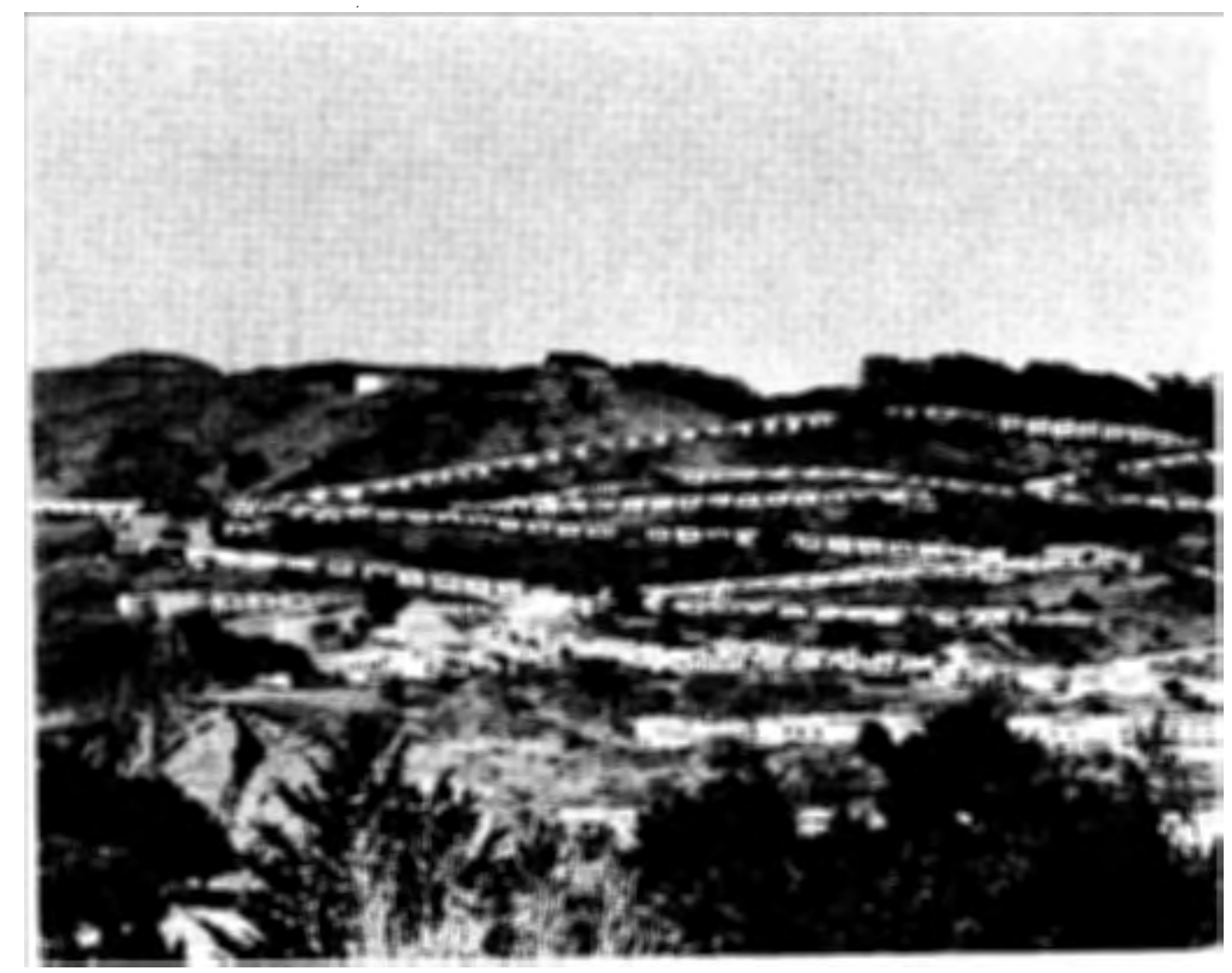

Figure 71. Little boxes al1 in a row, Daly City, California. George Staehli photo, 1987.

Early failures in the postwar home building efforts created a climate of suspicion about the general quality of the new homes. Mistakes were made in the mass building and marketing of homes; haste in trying to meet demand resulted in cases of poor quality control and misuse of unfamiliar or unproven new materials. Where new homes were built following prewar patterns of building on existing infill lots in established urban areas, the results were uniformly better. 
However, too many GI Homes were built in large groups which resulted in low-cost home ghettos soon changed from better maintained owner occupied homes to poorly maintained rental homes .

There was too little government control over builders, according to many public spokesmen. The housing industry was ill prepared to build so many homes in such a short time, and to police itself and guarantee good value. It was too greedy for quick profits regardless of long term community welfare. Many critics saw the government home financing aid programs, FHA and VA, as being hand-in-glove with the poor performing builders, especially the Veterans Administration's program which nominally conformed to FHA standards but left quality monitoring inspections almost entirely up to the lending institutions. The FHA standards in 1945 were much weaker than they were to become after the program encountered difficulties. Certainly, most communities were inadequately prepared to inspect the large volume of new homes and commercial construction and assure compliance with good building practices and building codes.

Oregon home builders were uncertain about their ability to meet new home needs. "Oregon Home Builders Planning Modest Budget", said an early postwar news story; the need was apparent but not backed up by the necessary resources and commitment.131 Further back in the same 
newspaper, "The House of Tomorrow---Dream and Hope of All," discusses the housing need and postwar expectations. House illustrations are shown from Paul R. Williams' The Small House of Tomorrow: "Cape Cod Modern," "Contemporary No. 7," "The Suburban," "The Devonshire," and "The New England." Concern is expressed in the article about the rush to build being in conflict with the resources of the home building industry. Prospective buyers are cautioned that the purchase price for a house should not exceed twice one's annual salary. 1,000 to 3,000 new homes are forecast to be built around Portland in the coming year, some homes will have electric heating, and a new model builders' house, one of Portland's most modern homes by Commonwealth, Inc., is described. 132

Most postwar FHA and VA program homes in the Portland area were built without the opprobrium heaped on homes built in other areas. Where the new homes were built in small clusters in established neighborhoods, or where the new subdivisions of homes were better planned, the homes have fared well and avoided most problems of decline in value and maintenance. None of the home builders in the Pacific Northwest began to approach the size of the larger merchant builders becoming active in other regions. The Northwest did have its problems, and the Standard Insurance Company

132 Helen Hoover, "The House of Tomorrow---Dream and Hope for Al1," The Oregonian, 6 January 1946, Magazine Section, p. 1 . 
financed Mittleman's Marlene Village project in a hollow

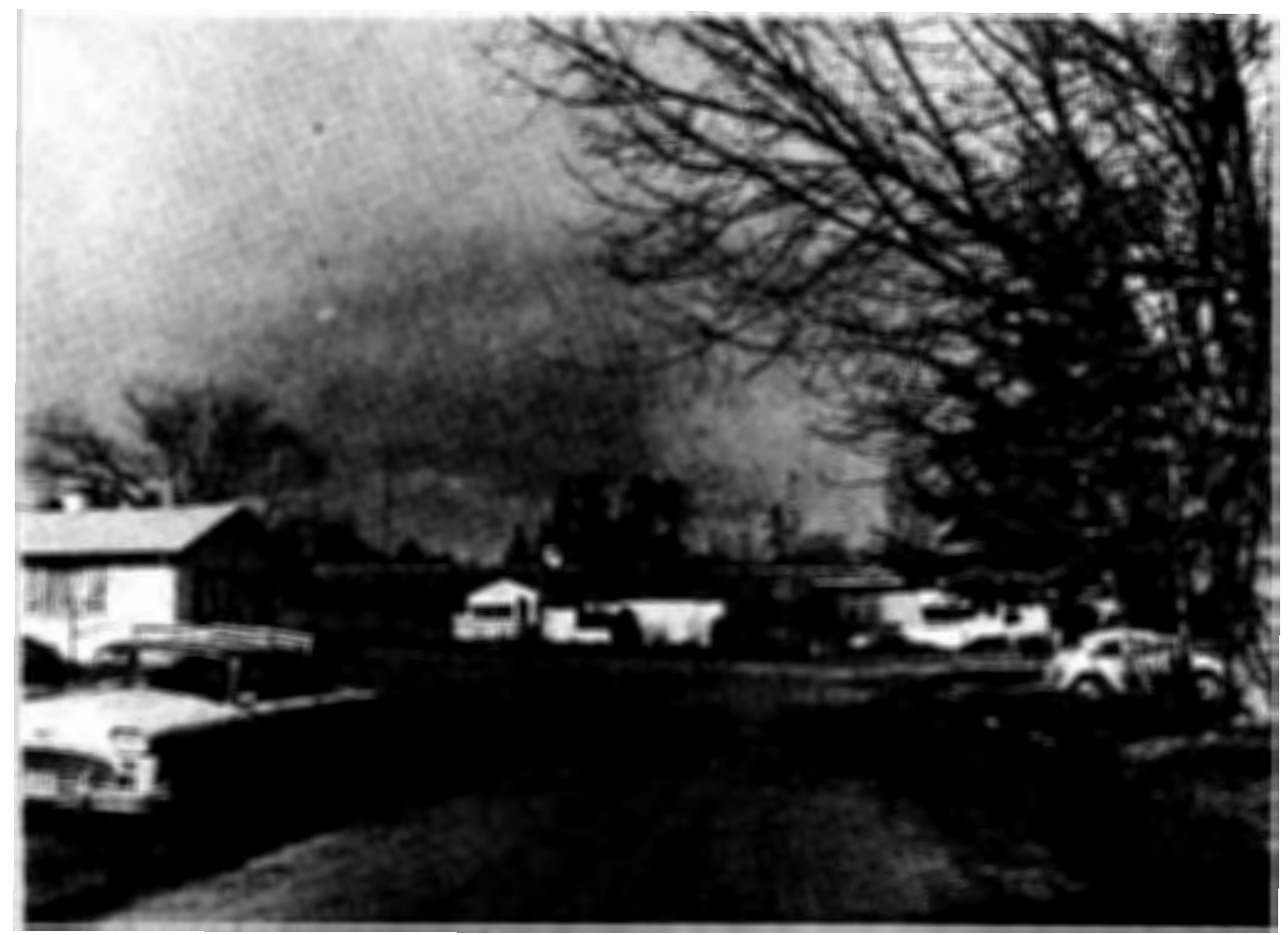

Figure 72. Marlene Village, Beaverton, Oregon.

below the Sunset Highway beyond Beaverton was just such a housing disaster. Marlene Village was in trouble from its beginning and has remained a sub-standard homes development. Marlene Village might have been the model for The Crack in the Picture Window horror story except that Crack is about the Washington, D.C., metropolitan area. Marlene Village occupies a low drainage course west of Cedar Hills and south of the Sunset Highway, east of Walker Road. The concept for the development followed the common subdivision planning ideals adopted since Greenbelt, curved streets, diversity of house plans and styles sited to break up the appearance of 


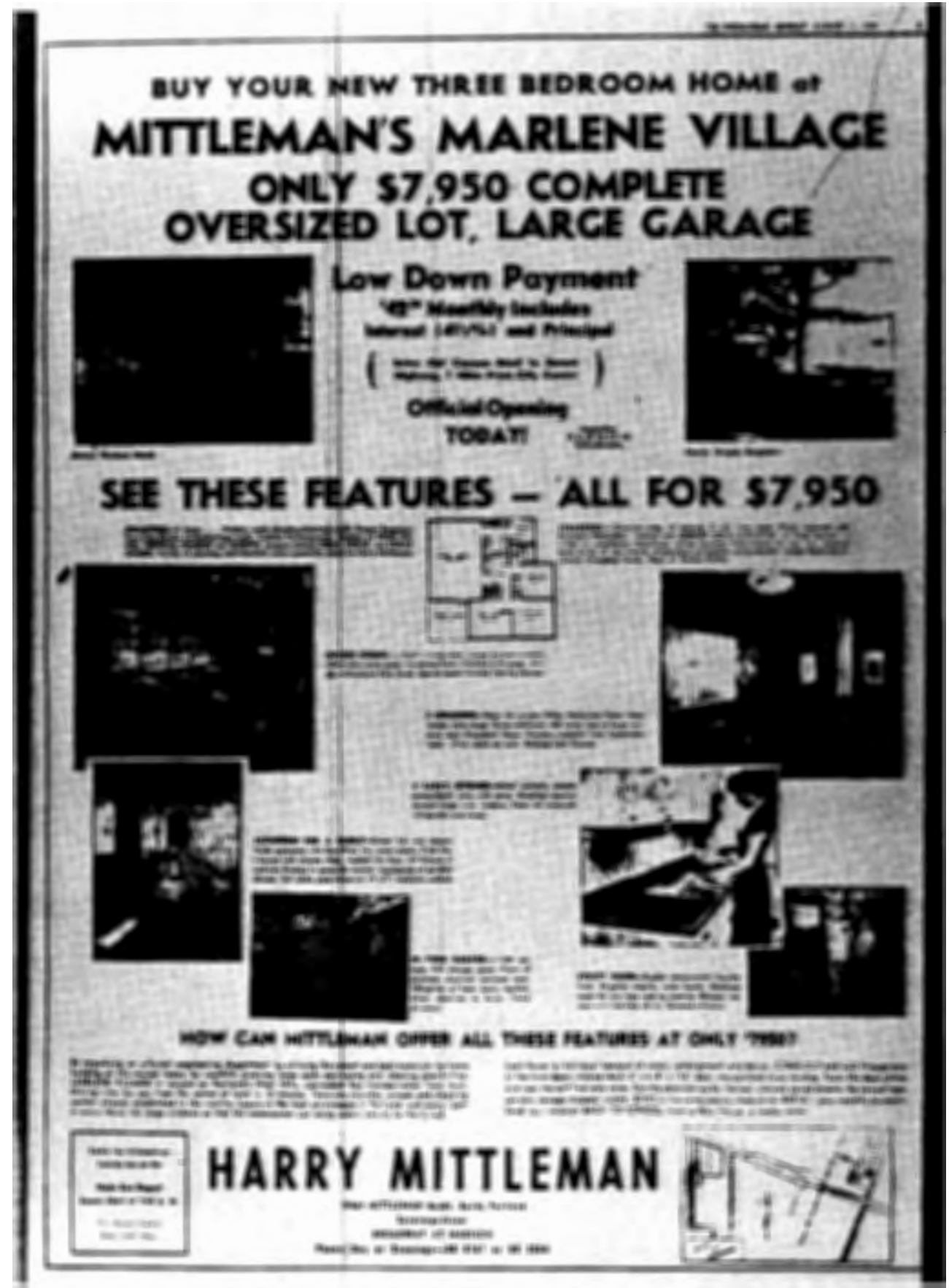

Figure 73. Newspaper advertisement for Marlene Village. From microfilm, Central Library, Portland. 
uniformity, and the preservation of some of the native trees. Homes in Marlene Village came in several plans for a basic three bedroom house, single bath, kitchen, utility room, and living-dining room. The advertisement described their "Eye Appea1---4 Types:"

Western ranch: (slanting shed-type roof), Oregon Bungalow, Rose City Classic (cathedral-type roof), Tualatin Contemporary. Exteriors of DROP SIDING, VERTICAL TONGUE and GROOVE pressure stained CEDAR SIDING, and CEDAR SHAKES. Variety of pleasing, individualistic colors especially mixed for Harry Mittleman. 133

Harry Mittleman was a prominent Portland apartment house builder and owner with no previous experience in small home building. His entry into postwar home building development was based upon his association with the city's finer apartment buildings and record of participation in a variety of civic enterprises. Low-cost home building must have appeared to be a potentially profitable extension of his previous investments. Standard Insurance Company was a conservative Portland based 1 ife insurance company, formerly named Oregon Mutual Life Insurance Company, just expanding into the real estate development arena. The original sales promotion was directed to eligible veterans and the $4 \%$ no down payment buyers. The advertisements tell about the availability of schools, churches, and shopping centers nearby. But, in fact there were no community services an, 14 August 1949, p. 5 . 
closer than a ten minute drive at that time, although an unsuccessful and unattractive shopping area was built on Walker Road on the edge of the development. The same advertisement also tells how to get there by means of "public transportation" by catching the Oregon Motor Stages' Seaside bus at the Portland bus depot and presumably asking the driver to stop along the highway shoulder to get off; there were no city busses running to the area or within walking distance. In 1949, Marlene Village was far out in the Washington County countryside beyond the fringe of suburbia.

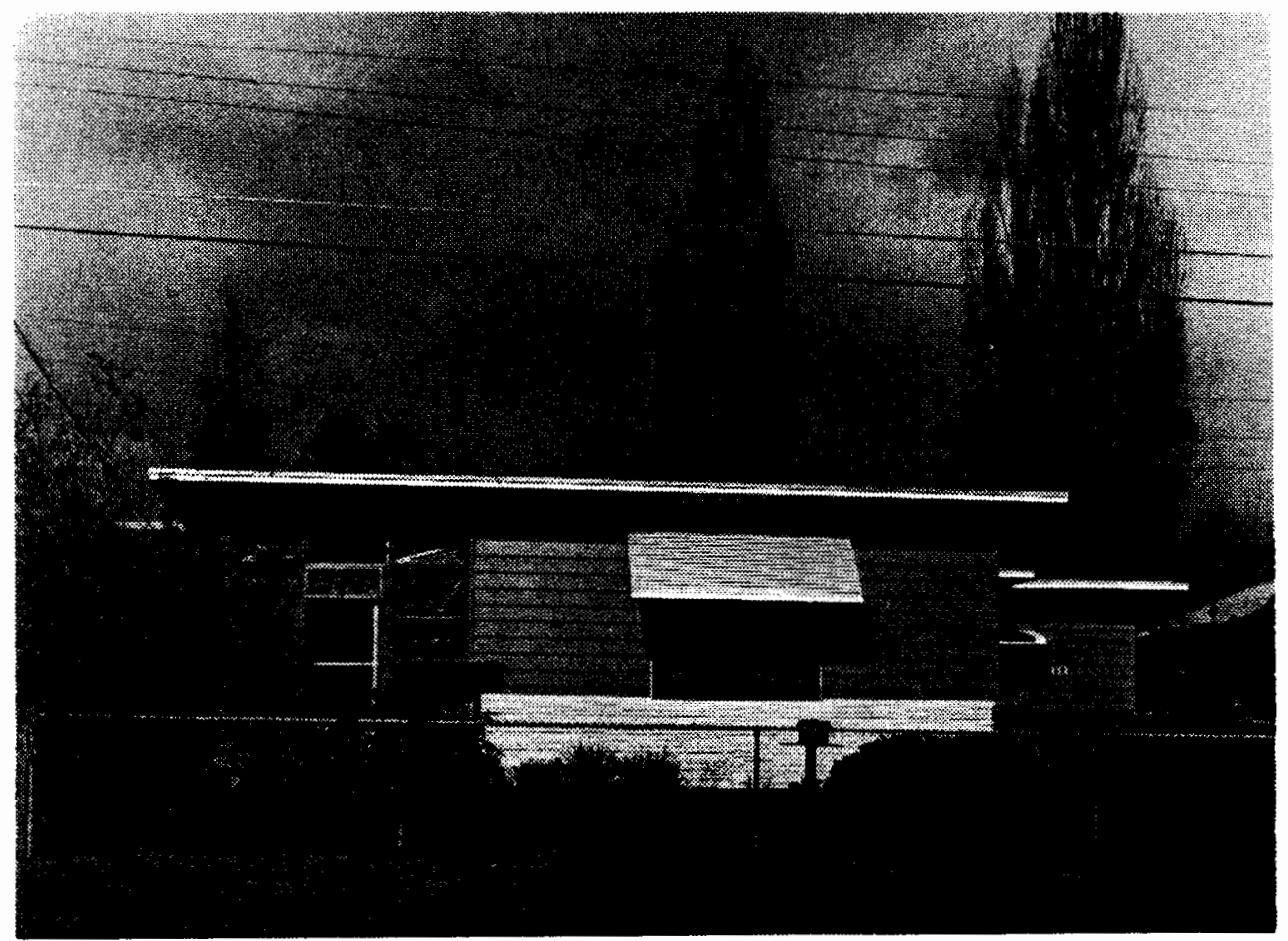

Figure 74. A Marlene Village house, 1986.

Marlene Village did not adequately plan for its low site conditions and drainage, both for storm water and 
septic tank effluent. Flooding was a problem the first winter, and the project was almost closed up by the county officials and by the Veterans Administration. Litigation over the drainage problem and other problems continued for more than two years while the purchasers of the houses alternately were faced with eviction or loss of VA financing eligibility as homeowners, Harry Mittleman, the Veterans Administration, county officials, and the Standard Insurance Company wrangled over deficiencies. Mittleman generally refused to acknowledge any faults or need to meet VA standards, taking the classic free enterprise position that he was just an honest builder being persecuted by government regulations. 134

The most spectacular example of faulty building in Marlene Village, or almost anywhere else, was the highly touted experimental installation of electric heat pump systems in some homes. These heating systems used pipe coils buried in the earth beside the houses to extract geothermal heat and transfer it to warm air within the houses by a refrigeration process. In theory, the house is warmed and the outside ground is cooled. Unfortunately, the

134The Oregonian, "Marlene Village Veterans Notified to Vacate Homes," 1 September 1949 , P. 1; and, "Veteran's Wife to Seek $\$ 26,000$.," I November 1949, p. 19. The Oregon Journal, "Marlene Tiff Ends---Drainage Pact May Help Vets Finance Homes," 14 December 1949, p. 1; and, "Marlene Village Residents plan fight to retain G.I. Loan Terms.", 29 August 1951. The Oregonian, "Sanitary Board Orders Marlene Village Firm to Report.", 3 September 1951, p. 4. 
first winter was an unusually cold one; and as the heat pumps strained to extract heat from the cold earth outside to warm the houses inside, the ground was frozen, heaved, and cracked the concrete garage floor slabs and foundations.135 Emergency repairs had to be made to many homes, and all the heat pump systems replaced with conventional electric radiation.

Marlene Village is a perfect example of the problems resulting from building a homogenous low-cost homes development rather than dispersing the same houses among both older and larger new homes. The area has remained a ghetto with many vacant houses, many that are poorly maintained, and also many maintained and improved by the owners with additions and landscaping. Today, community services exist not too far away and the entire development is surrounded by later developments so that the whole area is urbanized.

The houses in Marlene Village are somewhat untypical of the postwar builders' houses. Their designs are a credible attempt at providing qualities above the average builders' house design and looked toward the improved designs of builders' houses several years later. The use of

$135 \mathrm{Although}$ the heat pump problem was reported at the time in the newspapers, the story was not found for this study. I verified the information with mechanical engineer, Bruce Morrison, Portland, who had personally inspected the problems that winter. However, another engineer believes that the heat pumps were installed in the second phase Marlene subdivision west of Walker Road and not in the first Marlene Village houses. 


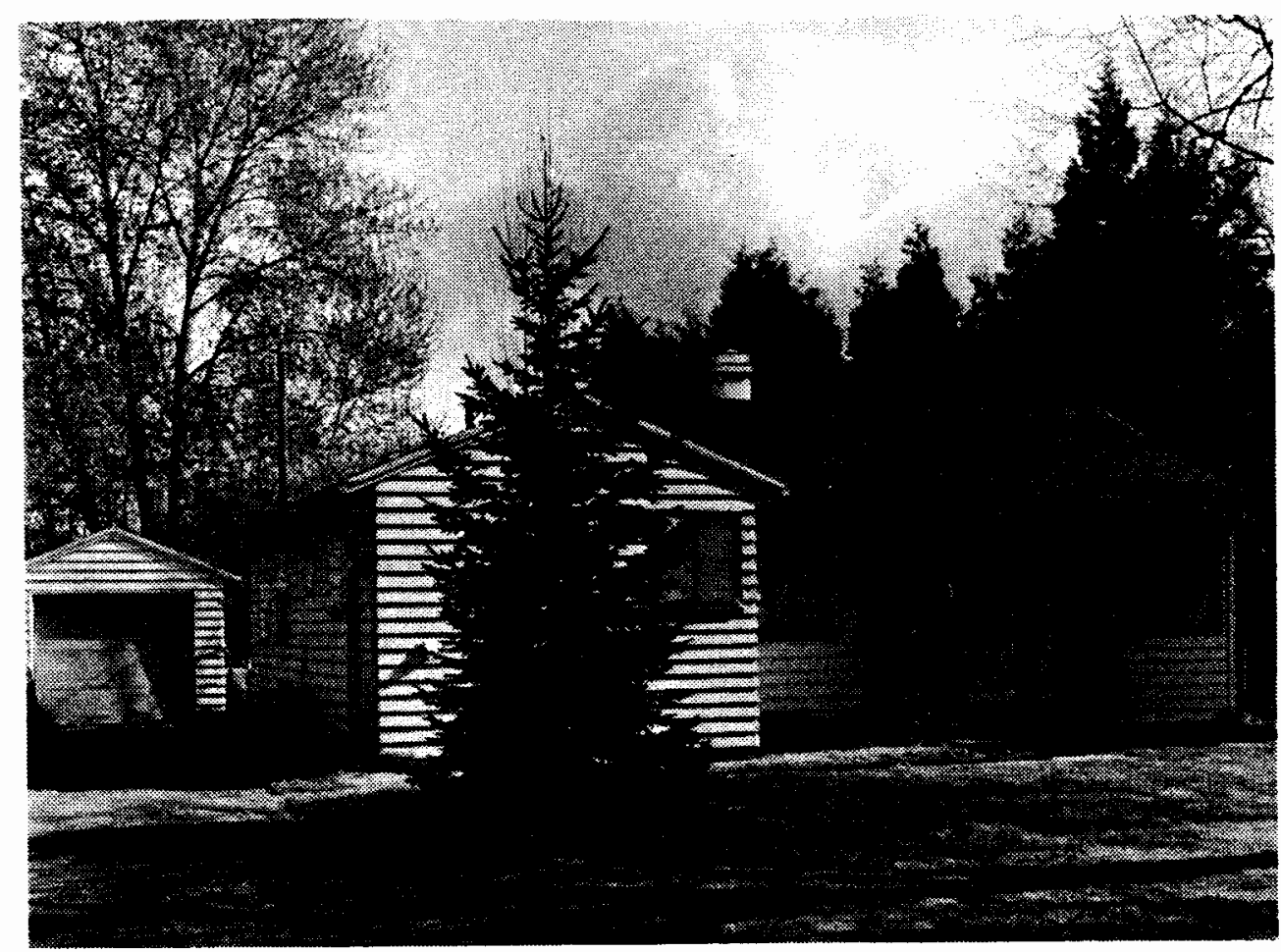

Figure 75. Marlene Village home. Many are now in generally good condition and attractive looking.

large modern front windows under a shed roof and open beam, "cathedral," ceilings was not common in 1949. The slab-ongrade floor and foundation was commonly used as was the rest of the wood framing and finishing work. The plans of Marlene Village houses also are a departure from the more linear standard of builder' houses, a clustering of the living and bedroom rectangle areas in an offset square arrangement instead of the more usual bedrooms at one end and living areas at the other end of a bisected rectangle. Marlene Village houses offered a garage instead of carport. Except for the early deficiencies of site and construction, 
the houses otherwise appeared to offer a very attractive value for the $\$ 7,950$. price.

\section{DESIGN CHANGES}

In a survey of home building plans and home design preferences among farm families, Successful Farming found that traditional style cottages were preferred by a large majority of midwest rural families.136 At home shows before the war and after, prospective owners rated the Colonial Revival models as their favorites; although one survey of attendees at the New York World's Fair in 1939, a showcase for the modern, found a majority in favor of modern design.

Interest in new houses and what they should be like was high. At the Home Institute of the Northwestern National Bank of Minneapolis' lecture series on homes in 1947 and 1948, nationally recognized speakers addressed the question of new houses and their qualities. The speakers were: John Normile, architectural editor for Better Homes and Gardens; Dorothy Liebes, artist and designer; William Scheick, coordinator of the Chicago Small Homes Council; George Nelson, architectural consultant for Time, Fortune, and Architectural Forum; Elsie Stapleton, New York City budget counselor; and writer-designer T. H. Robsjohn-

136 Successful Farming, "What a Thousand Farm Families Are Going to do About Building." (Illinois: Successful Farming, 1944). Small Homes Council library. 
Gibbings. Practical basics were emphasized by most of the speakers, the same advice that could be found in any of the home books. Modern design and good planning was advocated by George Nelson, particularly to avoid many of the builders' house cliches like picture windows that face a busy street. Robsjohn-Gibbings presented a departure, recommending to the home buyer that, after ali, the house

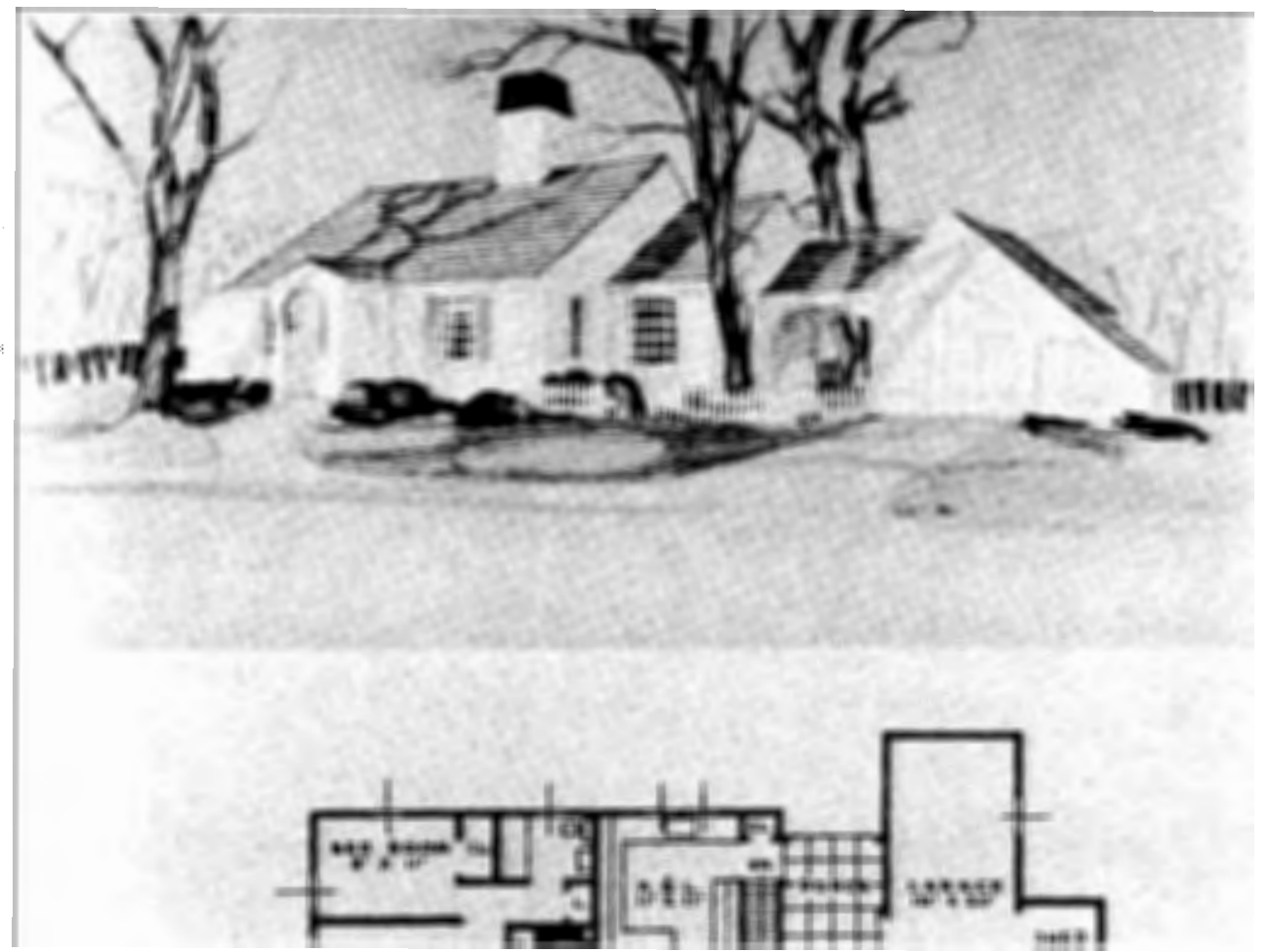

Figure 76. Colonial Revival Style house and plan. Royal Barry Wills' Houses for Homemakers. Modern style models and plans are included.

will belong to him and should fit his needs and tastes. The owner should not slavishly follow the modern furnishings trends. If overstuffed is what suits him, he should buy it 
and avoid the "dwelling machine."137

Plan books for low-cost homes by industry and private authors continued to show traditionally designed homes with just an occasional modern one. The American Colonial Revival Style continued to be represented more often than other traditional styles. Weyerhaeuser's modular homes in Modern Colonial Style varieties fill its 1948 catalog, although they also have one or two Modern Ranch variations, and one with 1940 modernistic raking porch posts.138 Most home plan books published in this period emphasized the FHA and VA purchasing programs and gave practical advice on selecting the best home for the buyer's needs and avoiding the jerry-built. Home books which were related to the established home magazine publishers, Curtis, Collier, TimeLife, preferred the traditional over the modern styles, conforming to the prewar dream home ideals instead of the leadership of the architectural avant-garde.139

137 Transcript of 1947-1948 Lecture Series, The Home Institute, NW National Bank, Minneapolis, Minn. From Sma11 Homes Council, University of Illinois 1 ibrary.

138 Weyerhaeuser Company, 29 Home Designs (St. Paul: Weyerhaeuser Company, 1948). Weyerhaeuser Archives, Tacoma.

139 Harold E. Group, House-of-the-Month Book of Small Houses (N.Y: Garden City Publishing Company, 1946); home plans from Colonial Revival to. International Modern. Dean and Breines, The Book of Houses, basics of home planning and buying. Richard Pratt, A Treasury of Early American Homes (N.Y: McGraw-Hil1 Book Company, Inc., 1946-1949); color illustrations of homes and their interiors from Early Colonial through Federal and Greek Revival. This is not a plan book, but is representative of those books which appealed to the more design oriented owners and building 

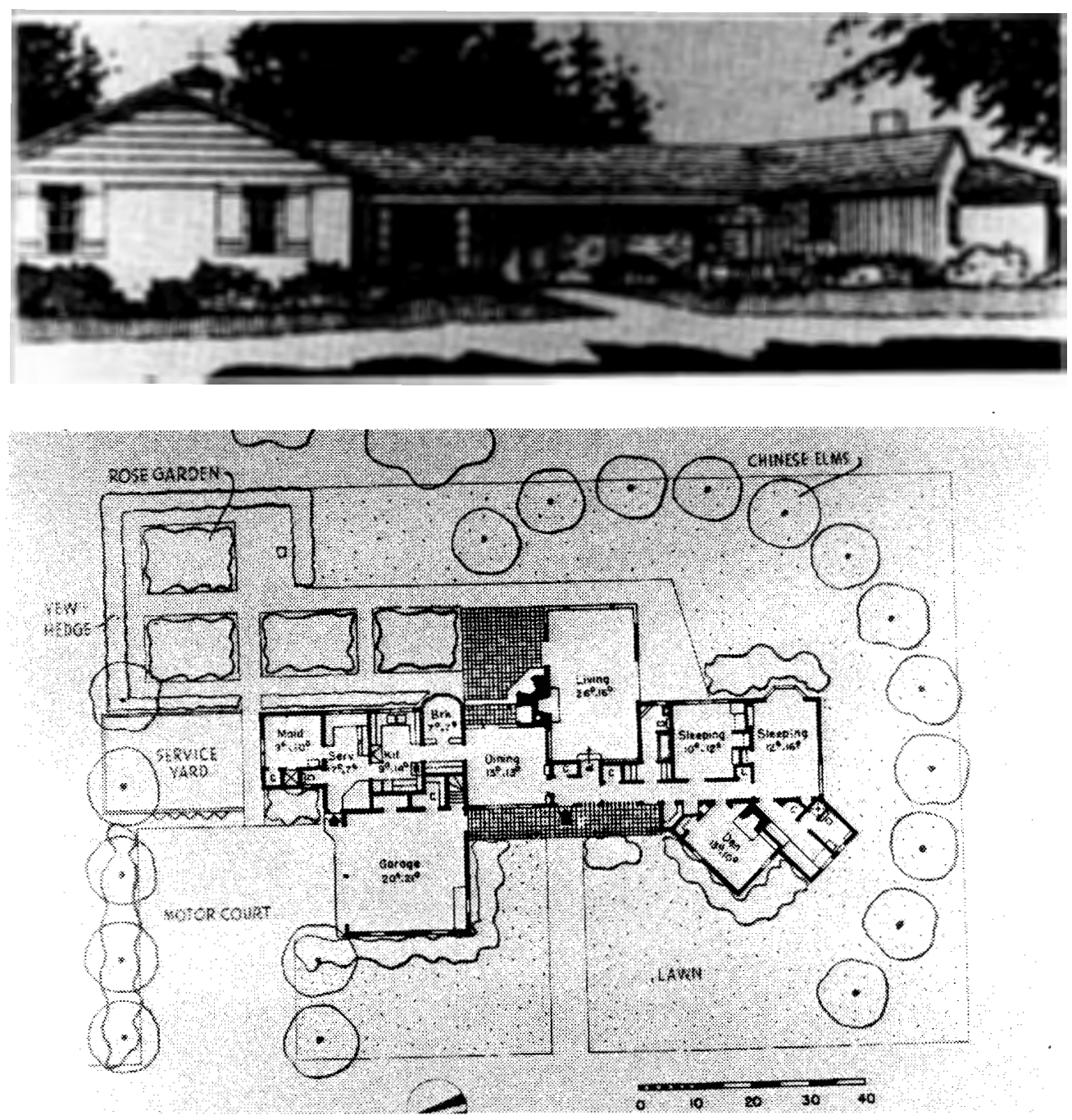

Figure 77. A Sunset Western Ranch Home. 1946 plan book.

\section{MODERN ARCHITECTURAL INFLUENCES ON THE SMALL HOME}

The leading architects and planners were not idle while the early home builders and merchant builders were meeting the demand with variations on prewar designs. The postwar period's housing shortage was the opportunity many 
leaders saw for making a break with the past and building the new tomorrow which would be cleaner, healthier, and less cluttered than the tradition bound past. Henry Wright pressed his position as Managing Editor of Architectural Forum and as a leading planner-architect, one of the proponents with Lewis Mumford of early New Deal support for low-cost homes, to present one of the most influential and clearly stated arguments for adopting modern architecture as best able to meet the need for good low-cost homes.

Tomorrow's House began with a quotation from Winston Churchill---apt in 1945---"We shape our buildings, then our buildings shape our lives!" which set the book's theme. It proceeded to analyze each quality of a home and to detail how the modern solution is preferable to the old one in terms of more efficient space utilization, adaptability to modern living, and lower building costs. The emphasis is heavy on sociological influences of homes on the lives and happiness of their inhabitants. Unfortunately, Wright's book shows among its illustrations almost no houses which could either be called small or low-cost, an indication of the fact that reverting to tradition, most architects were only too glad to move to the more profitable and prestigious higher priced custom home clients. The living rooms shown appear almost as large as the total area of most low-cost homes. What is communicated well, however, are some of the possibilities of good design to make multiple use spaces, to 

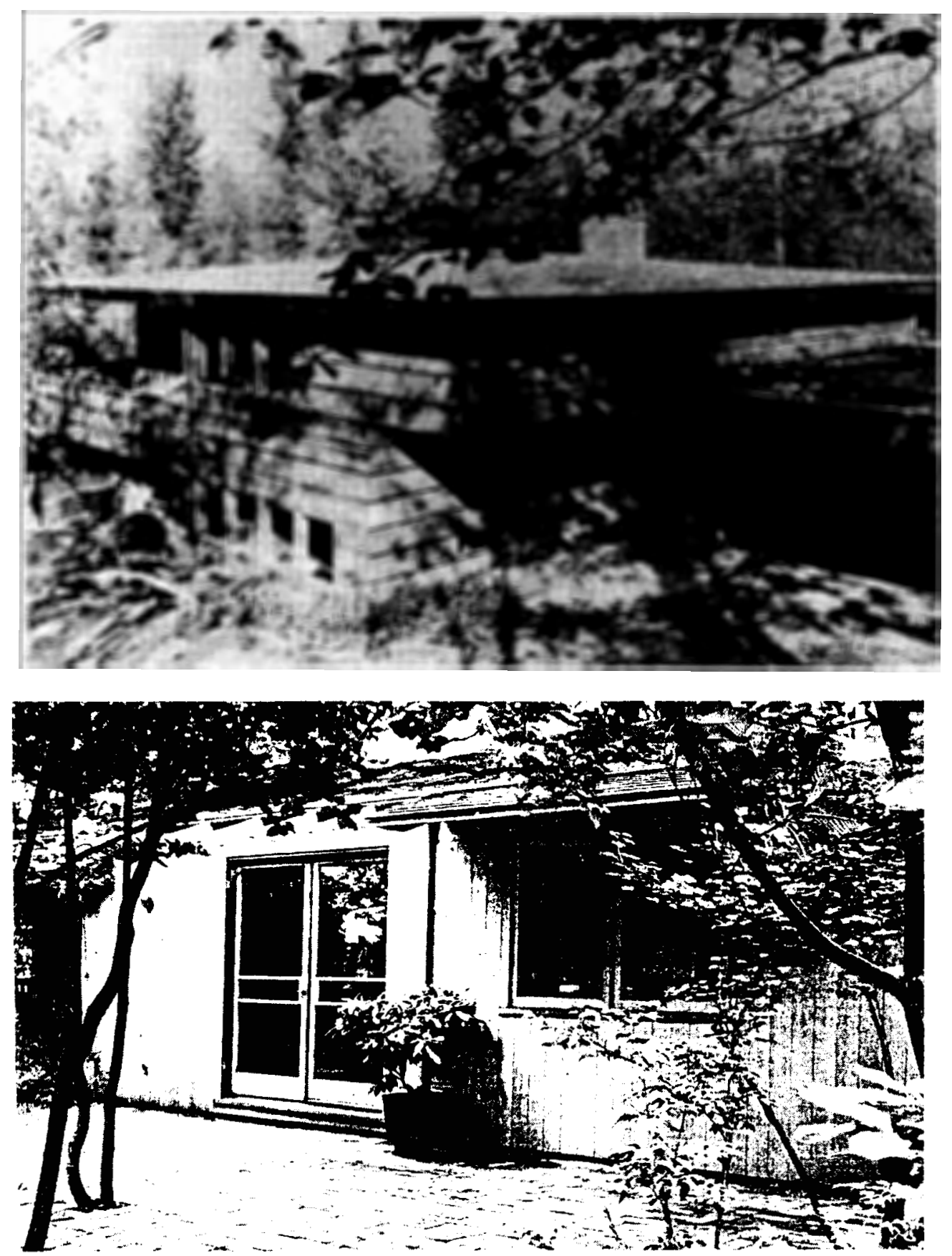

Figure 78. Modern home designs by Van Evera Bailey and Paul Kirk. The Book of Houses. 
use windows to make a room seem larger, to make pleasant domestic work areas, and to reduce with modern design the traditional clutter.

Architects had varied influences on the design of postwar builders' houses. Frank Lloyd Wright continued to write prolifically about architecture and homes but had little direct effect on popular housing. His plans for prefabricated and various types of low-cost homes and their communities met with little success; many of his prefabrication ideas did not prove to be either practical or low-cost, and his community ideas were too idealistic to meet with much popular favor. Wright's homes were preferred mostly by the few who wanted specifically to own a Frank Lloyd Wright house than to the democratic masses he presumably was addressing in his lectures. 140

If Frank Lloyd Wright had little impact on the American dream house, many other architects did contribute to its form within the limits of low-cost houses eligible for FHA insured mortgages. Many national and Pacific Northwest recognized architects had their designs featured in the home planning books. Van Evera Bailey and Paul Kirk

140Edgar Kaufmann, An American Architecture (N.Y: Bramhal1 House, 1960). Wright proposed many low-cost homes, his Usonian prefabricated designs and his small cluster Suntop Homes and Broadacre City homes (unbuilt). He designed for American Homes in the 1910s. Very few of his low-cost plans were realized; a few American Homes' pre-cut homes were built as were several Usonian models. Broadacre City was a schematic projection of America as an endless rural suburb. 
designs are frequent among the Modern small home designs. Royal Barry Wills continued to offer his expert Colonial Revival designs among the traditionally styled ones. The less extreme home designs from Bailey and a similar group of older converts to the International Modern, and from younger architects entering practice after the war, were more easily adapted to builders houses and found favor because of their use of labor saving materials and finishes.
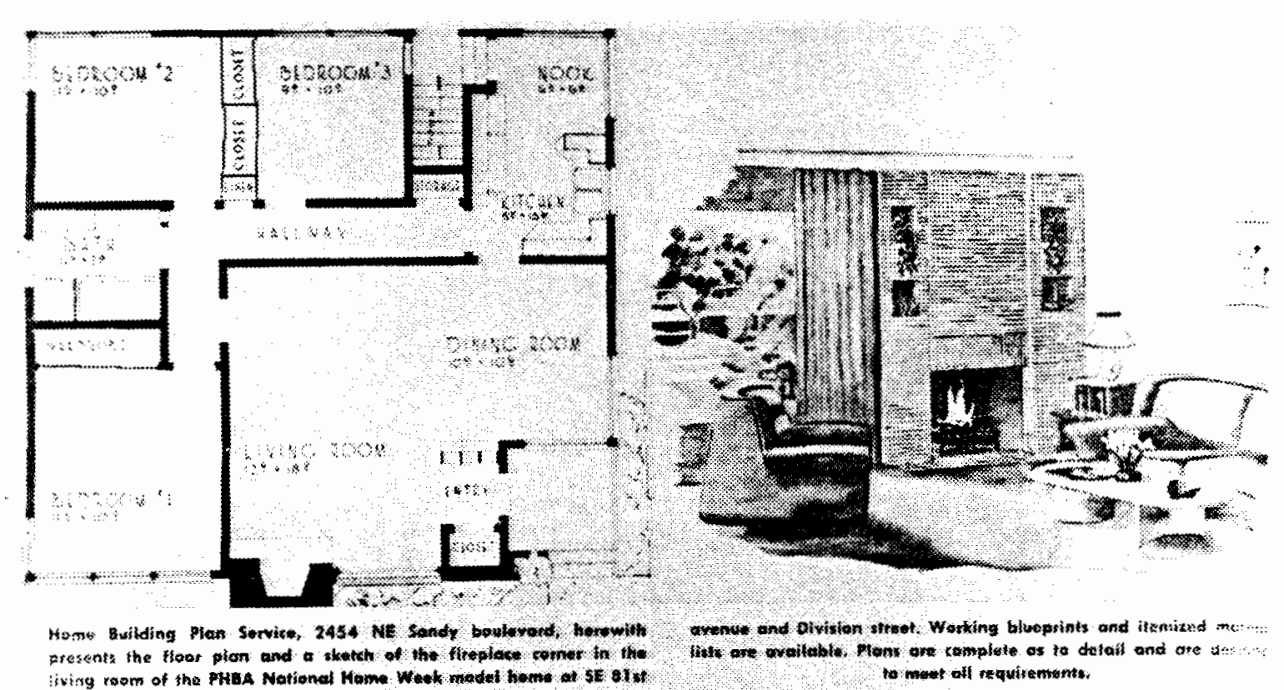

Home Week Model Home Designed to Fill Basic Needs of Average Family Group

SY GUN WYMETALE Hosmo sisidfing llan Serwice

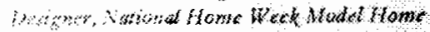

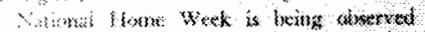

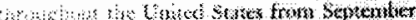

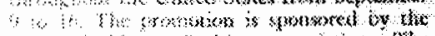

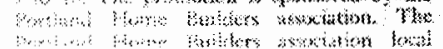

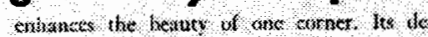

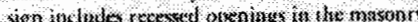

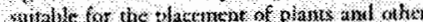

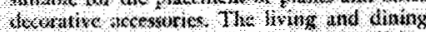

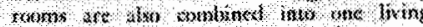

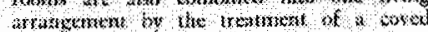
ensing thombliske.

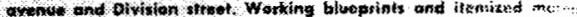

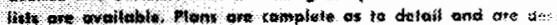
to mot off requirements

Figure 79. A typical modern open style house plan. 1951 National Home Week model at SE $81 \mathrm{st}$ Avenue and Division Street, Portland. HBAMP files.

The plans for postwar low-cost houses evolved from prewar traditional home plans with little direct influence 
from the modern architectural leaders. The architectural modernists were solving the small home problems in terms of multiple use spaces--the whole house as one living room when it is opened up, with movable dividers for separating the large room into private sleeping areas. Otherwise, most permanent dividers of the living area were designed as transparent screens to incorporate adjacent areas and outdoor spaces within the one visual space, making it appear larger. While attractive to many families which were

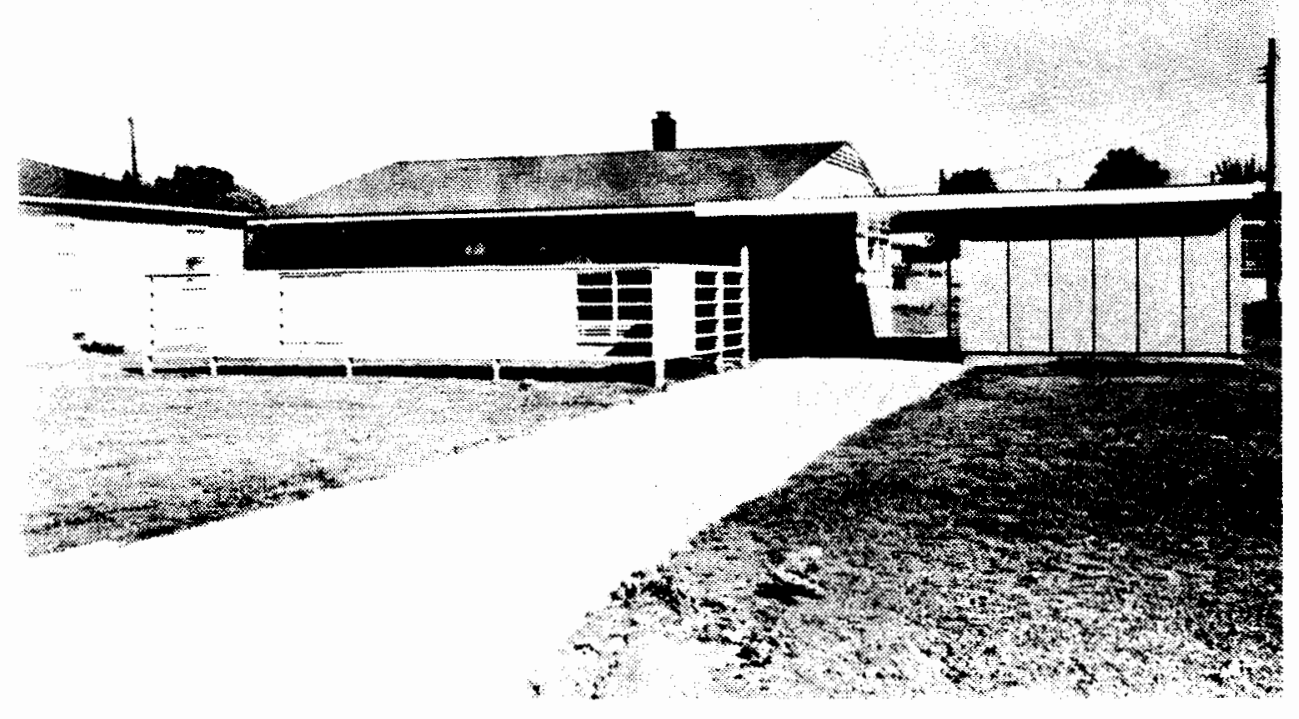

HOTSE "IN"

Figure 80. Smal1 Homes Council Demonstration House. SHC library, University of Illinois.

inclined to that kind of openness and the living patterns inherent in it, modernist home planning ideals were only 
marginally used for builders homes in the popular low-cost market.

The closest approach to modernist planning for builders houses was in the HHFA Demonstration House Project plans produced by the Small Homes Council at University of Illinois. These house plans are essentially square and are variations of the bisected plan type with two or three bedrooms along one side and the Iiving room, dining-kitchen, and bath on the other. The Demonstration House Projects homes employ "storage unit" partitions within the living area as space separators. They have good circulation patterns which avoid cross traffic within rooms, but do have somewhat more dedicated corridor space as a result.

\section{SMALL LOW-COST HOUSE PLAN TYPOLOGY}

The postwar small low-cost house plans fall into four basic types, the Square within an "L", the Interlocked "L"--or Yin-Yang, the Overlapped Squares, and the Bisected. Within each of these four, variations may be found as in all attempts to typify something as variable as house plans. There is a relatively consistent chronological evolution of plan types from the prewar traditional mostly square in " $L$ " type to the postwar Bisected plan. The Overlapped Square plan is unusual and was encountered only in the Marlene Village homes unless it is included as a variation of the Interlocked "L" type. Of the Bisected plans, there are both 

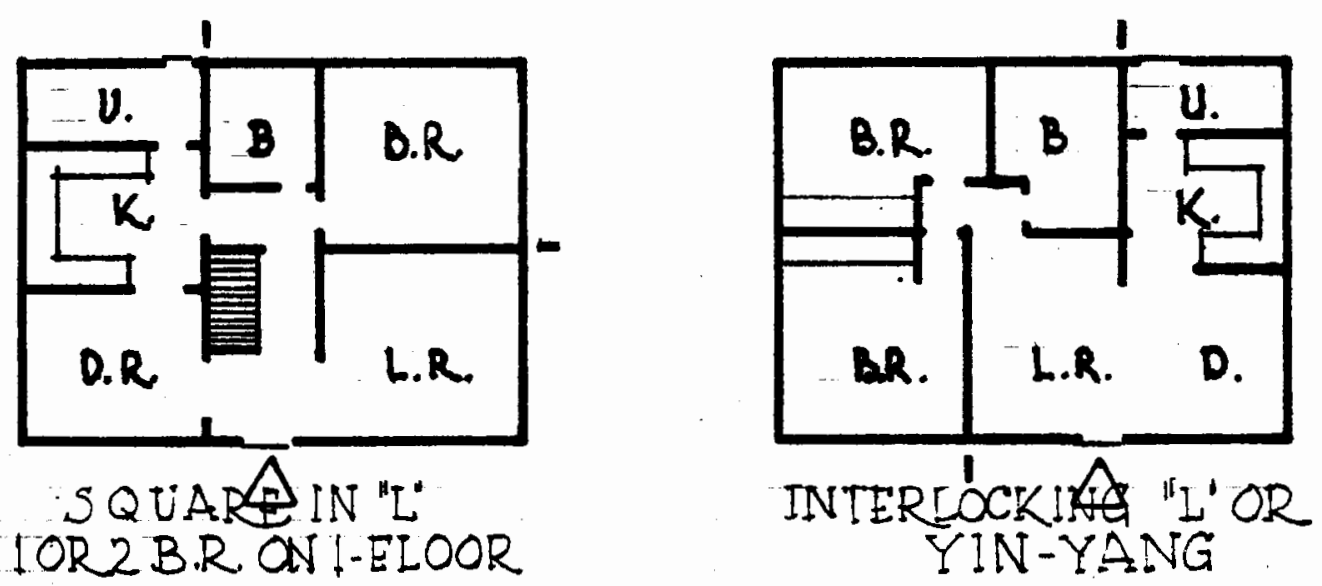

192

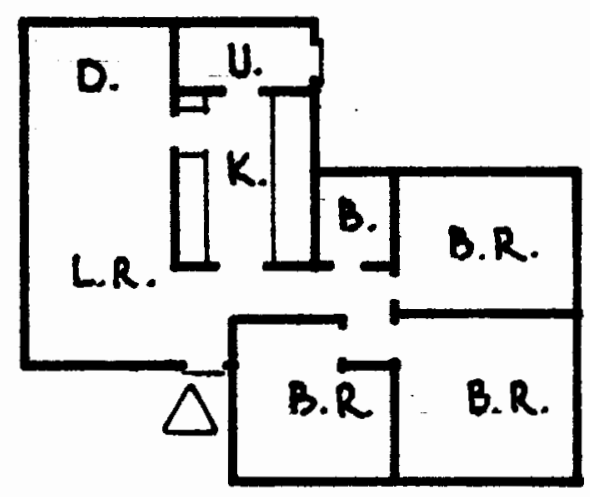

OVERLAPPED SQUARE
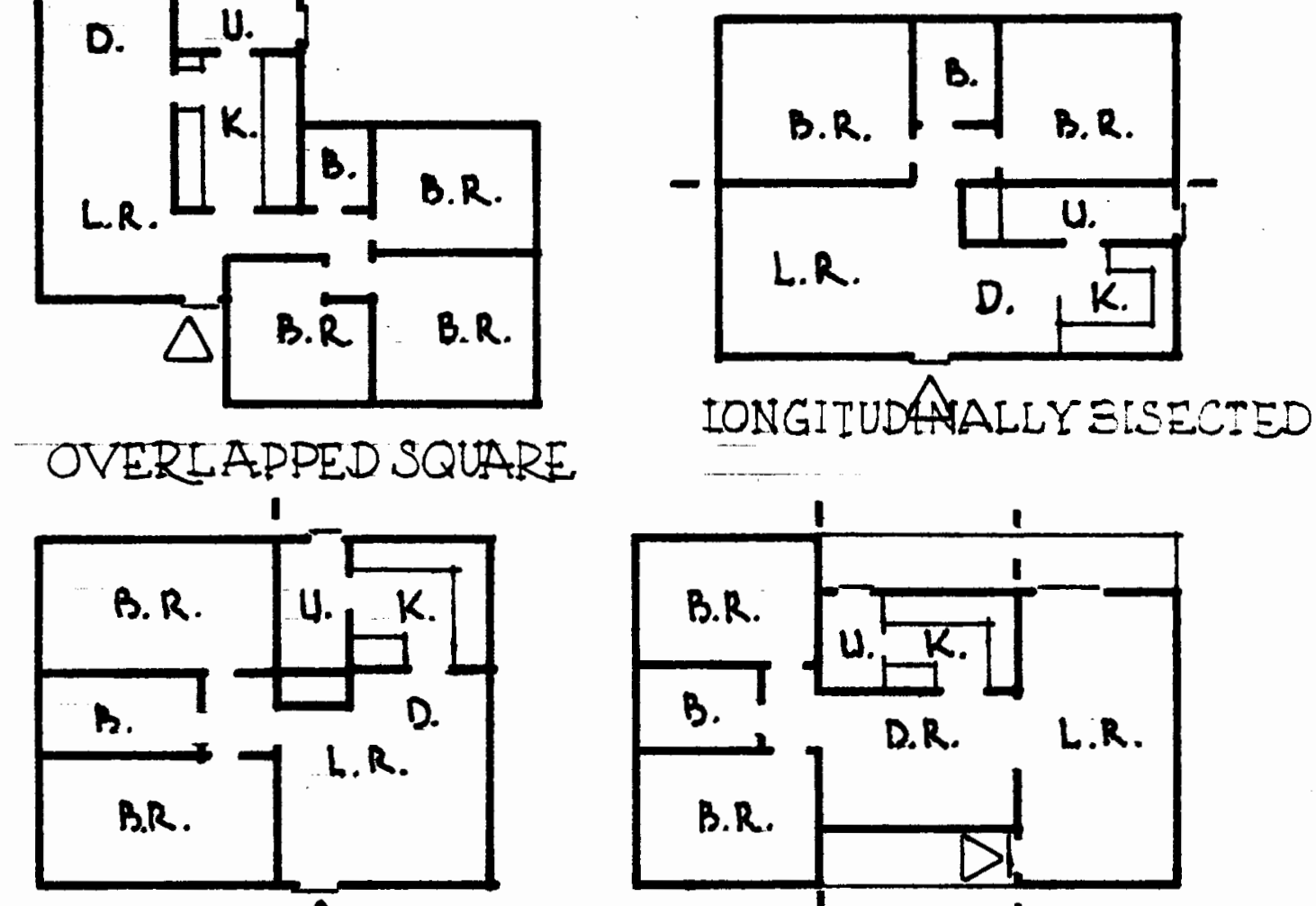

IRANSVERSA BLSECTED

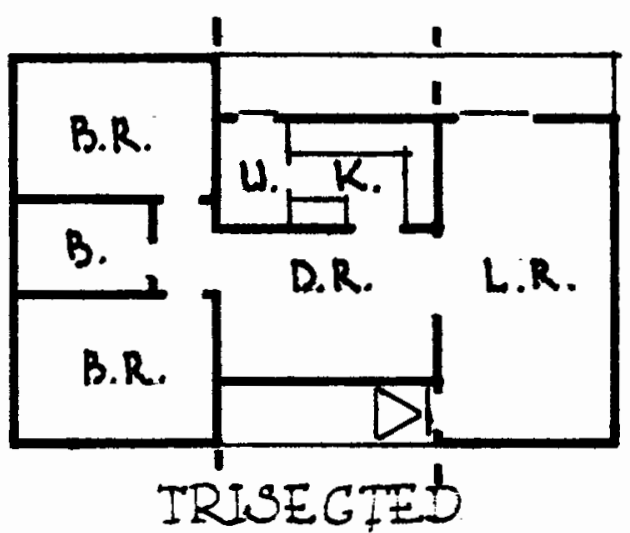

Figure 81. Varieties of typical small house plans. Within each, there may be many possible variations in partition divisions and closet locations. 
earlier and later variations, one frequently found in custom home plans and in the later 1950s' homes, the Trisected, with living area in the center, kitchen and services in one end and bedrooms at the other.

In the above plan types, the divisions refer to the primarily bedroom-bathroom activities and to the primarily living-dining-kitchen activities, each activity being contained in its respective square, "L", or sector-side. This typology does not include those plans primarily for two story houses which were not represented either in the Depression or afterward among low-cost builders houses---as distinct from one and one-half and two story FHA homes where there may have been bedrooms on a half or full second story, but where the primary bedroom and single bathroom remained on the ground floor.

The Square in "L" plan is one where the living area encloses two sides of a compact rectangle of bedroom (or rooms) and bath. It was very popular for one and two bedroom house plans where there is a more or less formal dining room on one side of the front, the living room on the other, and the kitchen and utility room behind the dining room with access to the rear yard. This plan in prewar Colonial Revival Style homes may have a small entry hall between the 1 iving and dining rooms and also have a stair up to the second floor, if finished, for one or two more bedrooms. It disappears from the later postwar house plans 
because it devotes a relatively large area for the dining room or very large dining-kitchen combined family room area. The Interlocked "L" plan type has relatively equal areas devoted to living and sleeping. It is found where there is a distinct three bedroom configuration. Depending on the plan, it might also be equated with the Bisected plan but with a jog. Where the orientation of the plan is transverse of the lot depth, there is through access from front entrance to back yard with the living room either facing the front with a "picture window" display of the family treasures or facing the rear yard and "patio living area." If the orientation is parallel to the lot's depth, access to the rear yard is by a kitchen or utility room side yard entrance, unless there are direct bedroom to yard doors found on later and higher price homes.

In the Overlapped Square plan, the 1 iving and sleeping area compact rectangles intersect in a common circulation core. The plan is very efficient and affords good traffic planning. It is less popular for builders houses because it multiplies the number of exterior walls from the irreducible four, except circular plans, to eight sides with eight corners and complicates the roof plan, all additional expenses for builders. It was undoubtedly used elsewhere, but in this study only at Marlene Village, Portland.

The Bisected plan became almost standard for postwar builders houses. Historically, it might be seen as a 
derivation of the early colonial houses which were two rooms separated by a chimney. Like the colonial houses which sometimes had an attached kitchen wing lean-to on the back or on one end, the Bisected plan house may have a kitchendinette wing attached to the basic house rectangle. This plan has a distinct division of 1 iving and sleeping areas within a basic rectangular plan. Some variations may have a projection of either the bedroom block or the living room, usually to define the main entrance, but the projection does not significantly violate the primary lateral or transverse division of the plan. Where the division is transverse to the depth of the lot, the living area is always on the street side and any access to the rear yard must be on one side and along the side yard, never directly out the back--the "picture window" must face the street! If the division is parallel to the lot depth, there may be a direct rear access to the yard with possibly some development of indooroutdoor living areas. When this plan is used as it often was for infill building on narrower inner city lots, the smal1 900 square foot or less, three bedroom, plans can be built on a 35 or 40 foot wide lot without other zoning code approvals. The Bisected plan was a very popular one for the hundreds of FHA minimum size three bedroom homes built in Portland and other cities from a variety of stock house plans and by many builders. The plan is often hidden behind 
an attached one or two car garage and many variations on the facade treatment of a basic gable roofed house.

\section{LOST ARCHITECTURAL ELEMENTS}

Certain architectural elements vanished very rapidly from the FHA insured low income house during the initial postwar years from 1945 to 1950. Exterior trim was reduced from the use of full moldings and finish associated with the traditional styles to the basic corner boards, plain facia on eaves, and the practice of omitting finished eave soffits grew. Any traditional door and window casing became limited to a simplified representation of the classic frame and entablature at the front entrance only. The adoption of pre-hung doors and self flashing and framed windows made it possible to eliminate 90 percent of the customary moldings. Interior finishes in economy houses were even more stripped of their usual trim. Some designers tried methods of selfedging the gypsum wallboard at door and window openings to eliminate all inside casings. Where casing and base are used, it is reduced to narrow "sanitary" or oval style. With the change to gypsum drywall interior finish instead of plaster on lath, the picture molding disappeared. The only finish differentiation between ceilings and walls was possibly a change in color, texture, or both. Ceilings became "brocaded," spatter-dashed---with or without mica spangles, or one of the other textured finishes which 

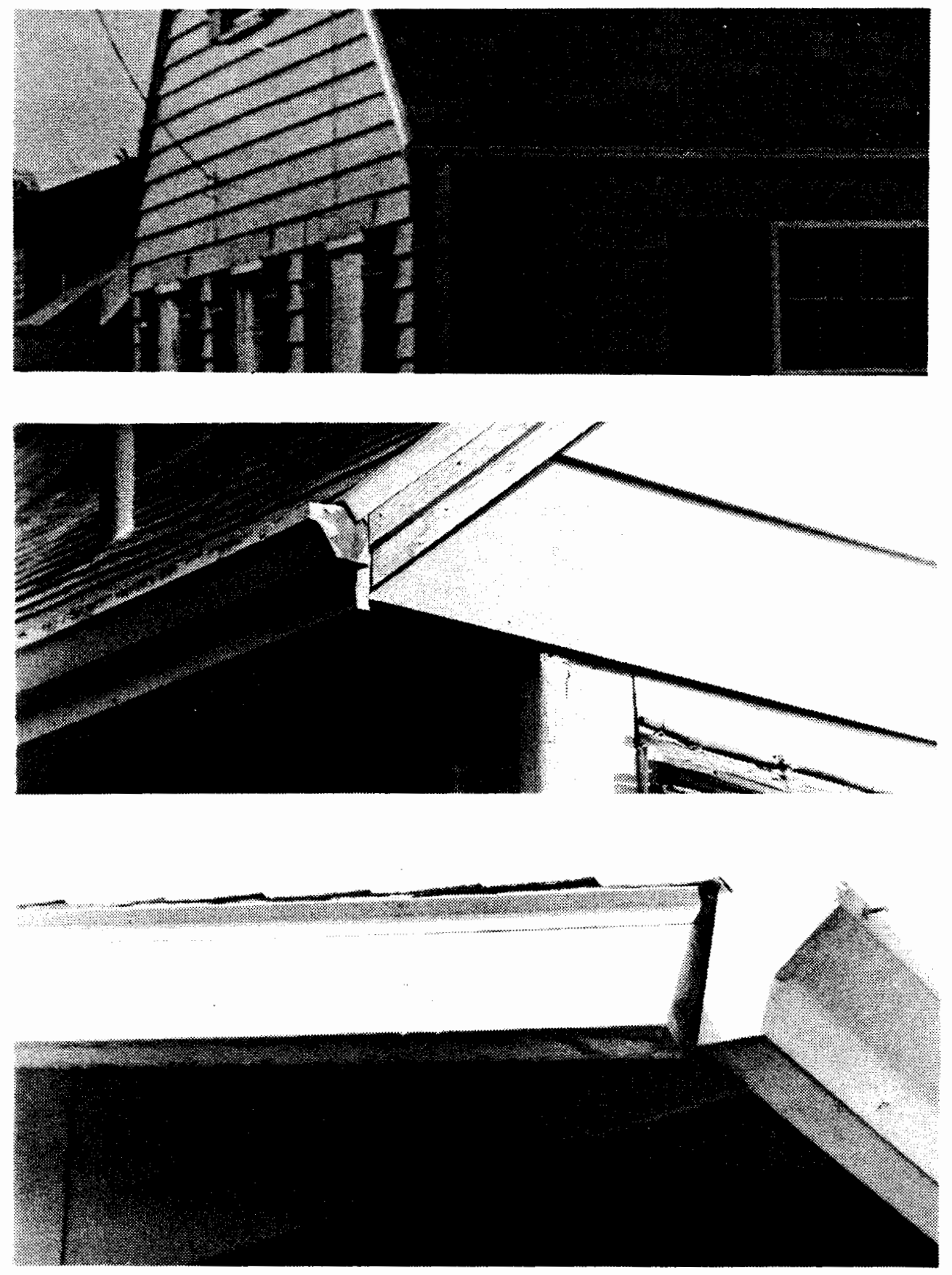

Figure 82. Changed eave details and finishing which characterize the prewar and postwar houses: complete finish in 1938, simplified finish in 1948, and no finish by 1954 . 
covered a multitude of defects and eliminated the normal joint taping and finishing hand labor. Eventually, paint coating products were developed which replaced both the drywall finishing and painting with one coat of a thick acrylic textured paint coating, "Monocoat" was one of these all-in-one finish products for both ceilings and walls. The development of low cost carpeting products then replaced the customary hardwood flooring, not the relatively expensive long clear flooring boards but the "shorts" which made a very satisfactory but low cost flooring used in builders' homes until supplanted with carpet installed directly over a subfloor and underlayment board.

In the case of cabinets for low-cost houses, these units were easily converted to factory production from onsite or custom shop manufacturing. Except for certain materials used in cabinet making, the change from solid lumber or plywood core panels to particle board core materials, many cabinets were as good or better than the prewar models. Obviously, there were differences in quality from one manufacturer to another, but the cost savings were more attributable to industrialization of the manufacturing than to lower quality materials; and the standardization and quality control of the new manufacturing processes could be better.

Like cabinets, other prefabricated house building units were adopted. Prefabricated framing systems did not 

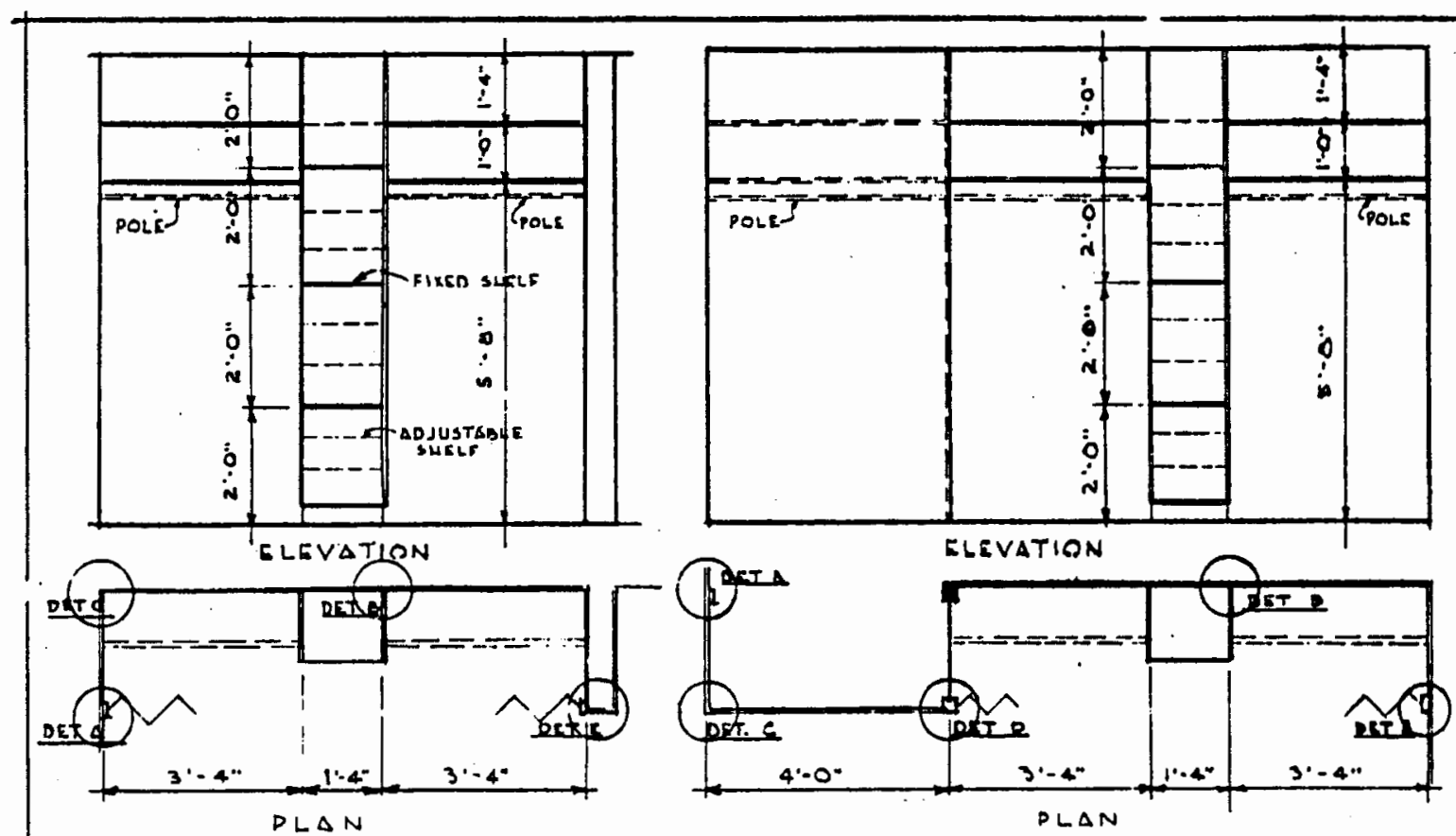

CLOSET NO.2

CLOSET NO:

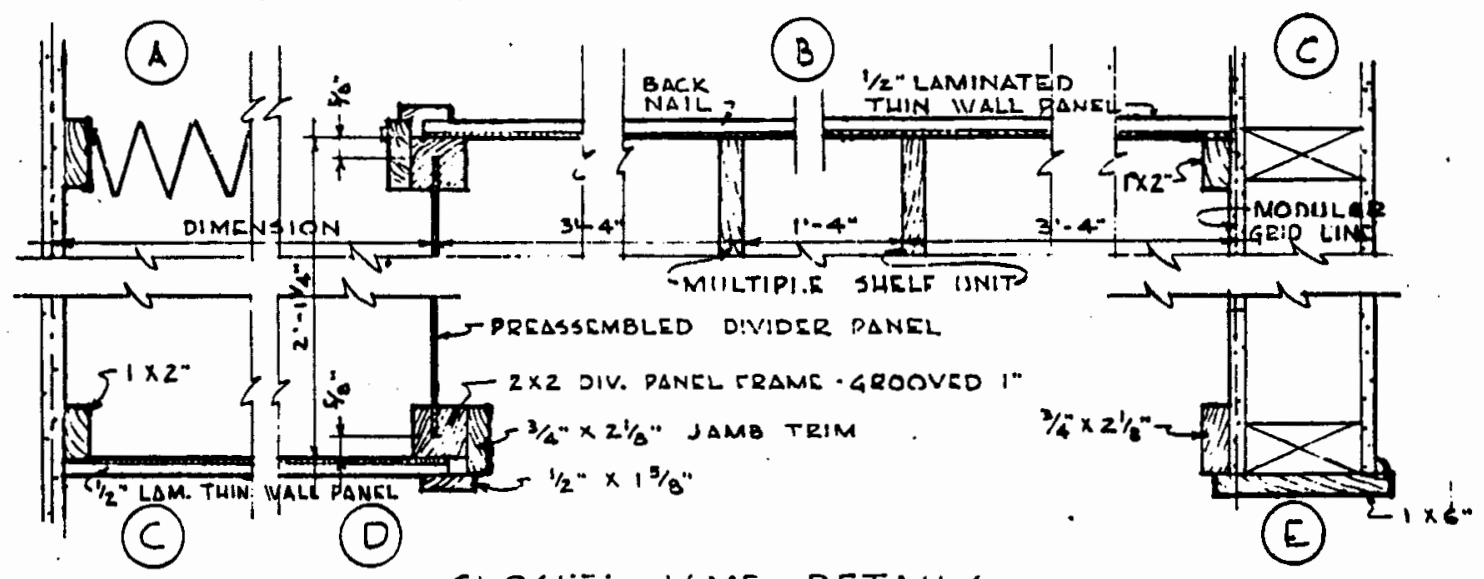

CLOSLI: JUAM DETAILS

Figure 83. Typical storage wall type cabinet details for builder's houses. Small Homes Council Demonstration Homes Project. SHC, University of Illinois library. These details are very like those designed by Van Evera Bailey for his Naval Air Station houses and his later stock house plans. 
become widely adopted. The site development costs, the foundations, weather conditions, and training of labor with the necessary skills to do as good a job assembling prefabricated house units compared to site-building in the customary way to achieve equal results eventually defeated all prefabricated house systems. They just never could compete in the permanent home market. Prefabricated house elements did compete successfully; such as roof trusses, some combination kitchen appliance and cabinet units, cabinetry as mentioned earlier, and pre-hung doors and self trimming windows. Only the evolved trailer house, today's manufactured home, has significantly incorporated prefabrication technology into builders' houses; but these home units are a fixed catalog of sizes and styles and not the almost infinitely variable house building unit systems that were the goals of the Depression and early postwar prefabricators.

\section{THE TYPICAL SMALL POSTWAR HOUSE}

The early postwar low-cost dream home, whether FHA mortgage insured or VA, was most likely a two bedroom one story cottage with no basement or cellar. The earliest houses had wood framed floors over a crawl space and soon were replaced by the concrete slab-on-grade floor type. The houses were generally not over 1,000 square foot in area, many much less, and with five rooms counting the bathroom 

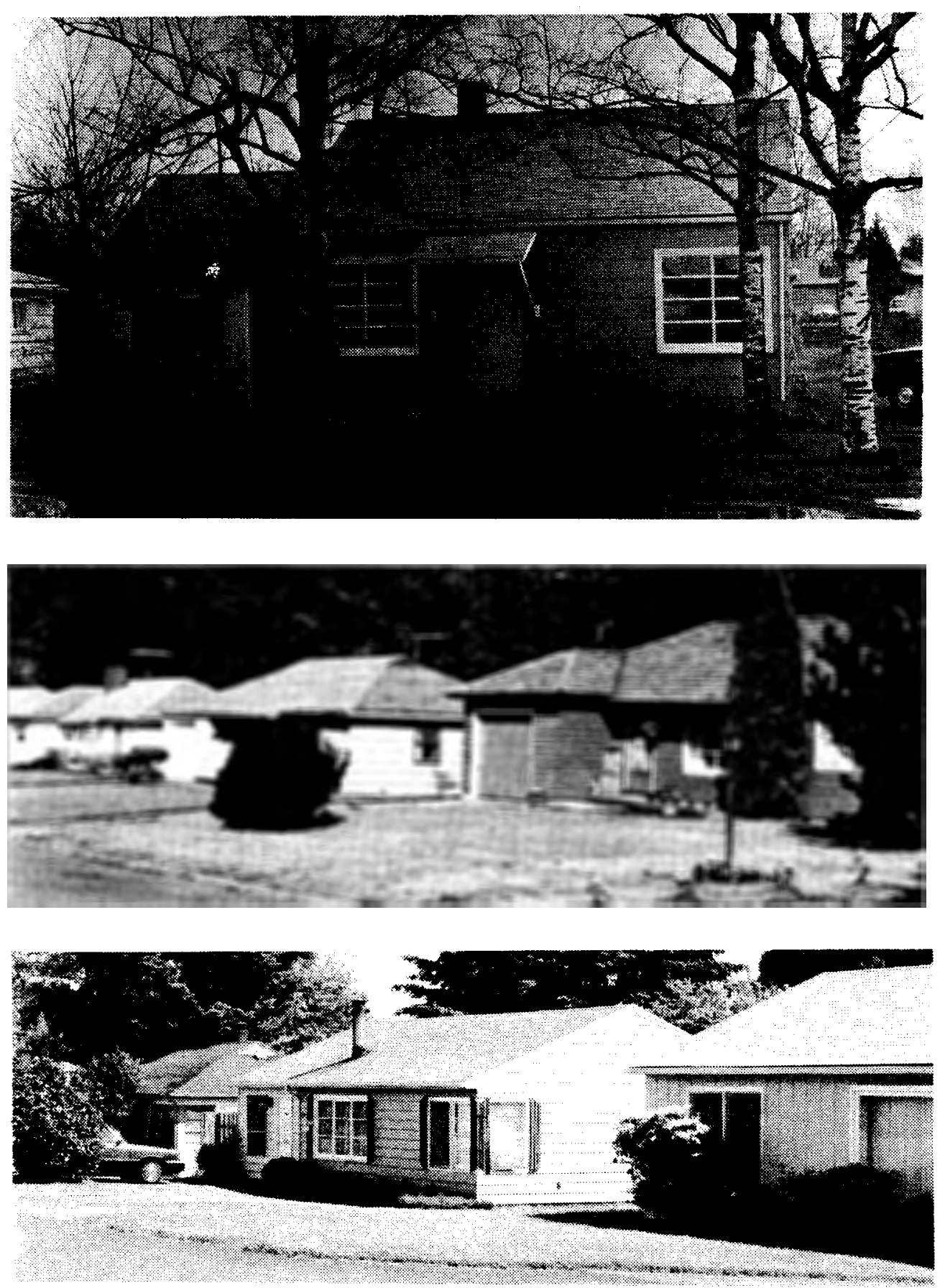

Figure 84. A parade of 1946 to 1954 low-cost homes. Top: First GI home in Portland, NE 97 th Ave. Middle: Cedar Hills. Bottom: West Marlene Village. 
and a combination kitchen-dinette room. The plan was either a basic Square in " $L$ " or a Bisected type about equally divided into living and sleeping areas with fully partitioned bedrooms. Interior finishes were plain, sometimes a "feature wall" with some kind of wood paneling or brick masonry if there was a small fireplace. The earlier Colonial Revival Style small windows were gradually enlarged into the Modern Colonial Style and later Ranch Modern or Modern style with picture and corner windows. Roof slopes were quickly lowered and sometimes reduced to low flat or shed roofs to save attic space cost, also foreclosing on any possibility of finishing an attic for habitable space. The early exterior finishes continued the use of traditional masonry and horizontal, vertical board and batten, and shingle sidings; but these were eventually supplanted by the combined exterior plywood panel siding and sheathing. Because of the more prevalent postwar use of common 1 umber for exterior finishing along with the rough textured sidings without trim, house paint and trim enamel finishes were replaced by one coat of exterior stain.

The result of these changes and economy measures was a very small house, although not appreciably smaller than many built in the Depression and earlier, occupied by a family of three or four (and growing) which had rising expectations of moving to a larger house farther out in the suburbs or in another city as the family's size, prosperity, and job 
mobility grew.

By 1951 , the trend away from the under 1,000 square foot starter house was well underway, and many early home buyers were ready to trade up. Home buying had become almost 1 ike car buying. With an inflationary market, it was almost as easy to dispose of the old house and buy a new one as it was to trade for a new refrigerator---in fact, the

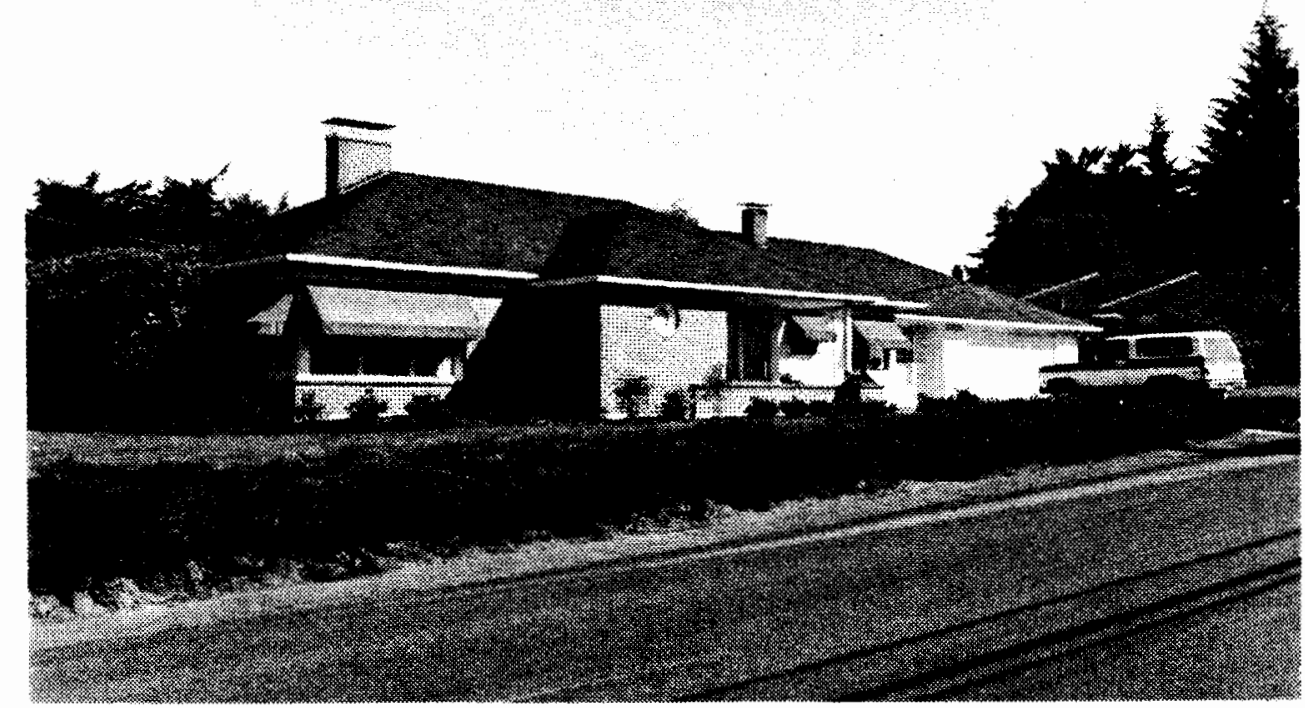

Figure 85. One of the larger homes typical of 1954. SW Canyon Drive, Journal "Home of the Week" model.

appliances now came with the house and were included in the thirty year mortgage. At home shows of all kinds, in home plan books, and in the magazines and newspapers, the ideal popular home was now at least three bedroom size and a little more than 1,000 square feet in area, generally a 
Modern adaptation of a traditional style if not completely one of the modern styles, and was a little farther out beyond the city limits. The garage might be optionally one or two car size with both cars parked outside because the garage was full of family storage and possibly shop and garden equipment. The Bisected plan type was now almost universal and is almost always aligned across the width of the generally larger suburban lot. Many builders employed architects to design their basic house model; and concessions are made to adapting modern home design principles, but the preference in builders houses is for clear separation of spaces and functions for fundamentally traditional family lifestyles.

The materials and finishes of the 1950s' houses are the same as developed in the early postwar period, basic and without elaboration. The principal distinguishing feature of the later houses is their more consistently modern appearance and large 1 iving room picture windows. 
CHAPTER IX

CONCLUSION: CHANGES IN BUILDERS' HOUSES OVER 20 YEARS

The architecture of builders' houses built under the Federal Housing Administration mortgage insurance program underwent lasting changes from the Depression era beginnings to the post World War-II home building boom. The combined effects of the evolved FHA building standards, making the possibility of realizing the American dream of home ownership a reality for almost any employed family through the FHA and VA programs, building industry changes, changed labor conditions, and wartime perfected new building materials and systems, produced low-cost homes which constituted a major departure from all previous small homes building practices. One period of American small homes types had ended with World War-II; a new one began in 1945 and was well under way in 1954.

FHA STANDARDS CHANGED THE HOME BUILDING CODES

Unfortunately, a complete set of the Federal Housing Administration's Minimum Property Requirements and the related earlier titles could not be found. Only parts of and references to the earlier 1930s' "Construction Standards" and other named guide publications were available for 
study. The earliest full set of Requirements was a 1947 booklet which consolidated the various "Acceptability Requirements," "Minimum P1anning Requirements," "Building Planning Requirement," and "Minimum Construction Requirements" as chapters of a single document. It was not clear whether an earlier edition of this compilation had existed before the war or not. Later editions of the MPR for 1952 and 1966 were available for study. The documents show that there was a steady progression from simple outline requirements to more specific requirements over the years.

Revisions incorporated the lessons of accumulated experience and the products of both government sponsored and industry generated research into better building methods and new materials and systems. The evolved Minimum Property Standards have all and more of the provisions found in building codes for single family housing, indeed were more comprehensive than the early model building codes and the codes adopted in many communities. The standards provided leadership in developing the modern building code provisions for homes.

The influence of the FHA Standards on the model buildings codes was such that the codes eventually adopted nearly identical provisions; and, in 1985, the Federal Housing Administration terminated its separate standards in recognition of their duplication in the current model building codes which are now used almost universally throughout the 
country.141 In general, the FHA Standards defered to local building and zoning codes wherever those requirements were more restrictive than the government ones, but in many cases the FHA ones were the same or stronger. As nationally recognized materials and testing standards were developed, those standards were incorporated in the MPS editions so that, for small and medium size homes, the FHA document was the primary document unless there was a locally adopted code which was more restrictive. Nothing in the FHA MPS standard could supersede a more stringent building code standard; but where the FHA requirement was the more limiting, the home had to comply in order to be have its mortgage insured.

In its operation, the FHA program was administered with reasonable diligence to see that its standards were met. Each FHA office had its own inspectors whose job it was to periodically inspect new homes under construction and to certify that the standards had been met. If a builder failed to comply, the deficiencies had to be corrected and compliance certified before the loan was approved.

Veterans' Administration insured home loans generally conformed to the same FHA standards. The VA program, however, relied on the builders and financing companies to self police the enforcement of the MPR requirements. The

141 "FHA Property Standards Give Way to Local Codes," Multi-Housing News, September, 1985, p. 6. John Herbers, "Plan to drop federal building standards sparks controversy," The Oregonian, 18 August 1985, p. A17. 
Veterans' Administration was not engaged in research and standard setting in the way that FHA was and was more subject to local manipulation in the processes of building and financing its houses. Most $10 w$-cost houses, however, were built so as to comply with either financing plan; and unless there were deficiencies found during the loan application inspections which had to be corrected, a typical house met both programs' requirements.

\section{HOW WENT THE DREAM?}

How successful the FHA and VA programs were in making the American dream of home ownership a reality depends on how the goal is defined. There is no question about the great number of houses that were built following the Second World War. There was a home building boom which may have never totally met the need but which certainly built more houses than during any previous time, and built houses which met defined basic standards for minimum space requirements, soundness of construction, and other quality controls. All previous small homes had only to meet whatever building codes pertained to homes, very often none, and any self administered standards as defined by the building trades and generally accepted practices. As a result, the percentage of private home ownership reached an all time high. A United States Savings and Loan League's study found that $51.4 \%$ of families owned their own home in 1948 as compared 
to $40.9 \%$ in $1940 ; 2.2$ million homes had been purchased in 1947 of which $39 \%$ were purchased by families earning an annual income of less than $\$ 3,000.142$

Except for the more notable problem home developments where there were major deficiencies, the examples of poor homebuilding practices and planning are remarkably few, limited to the occasional development which was just too homogeneous to be healthy and has deteriorated into a lowincome ghetto or with poorly maintained rental houses with too many vacancies. The matured Levittown is now a successful, prosperous, and generally attractive neighborhood. Even Marlene Village does not look as bad today as it had promised to look given its birthing problems; there are still too many vacancies and poorly maintained houses, but the majority appear to be owner occupied and to have undergone the maturing changes which have saved many other developments done in the same period. Wherever the 19451954 period houses are either dispersed among other houses from different periods or are representative of the 19511954 end of the period and those houses which were a little larger and more architecturally varied, the houses remain in as good condition and as well maintained as any others in

142 "Portland Home Show" section, The Oregon Journa1, 9 May 1948. Another article rhapsodized about traveling by helicopter from east 135 th Avenue to Beaverton and, "Nowhere does the city's limit appear as a line of demarkation between small farms and rows of houses.... Only a few dairies and a few steep hillsides stand unmarked by new streets, new houses, new signs of construction for a new community." 

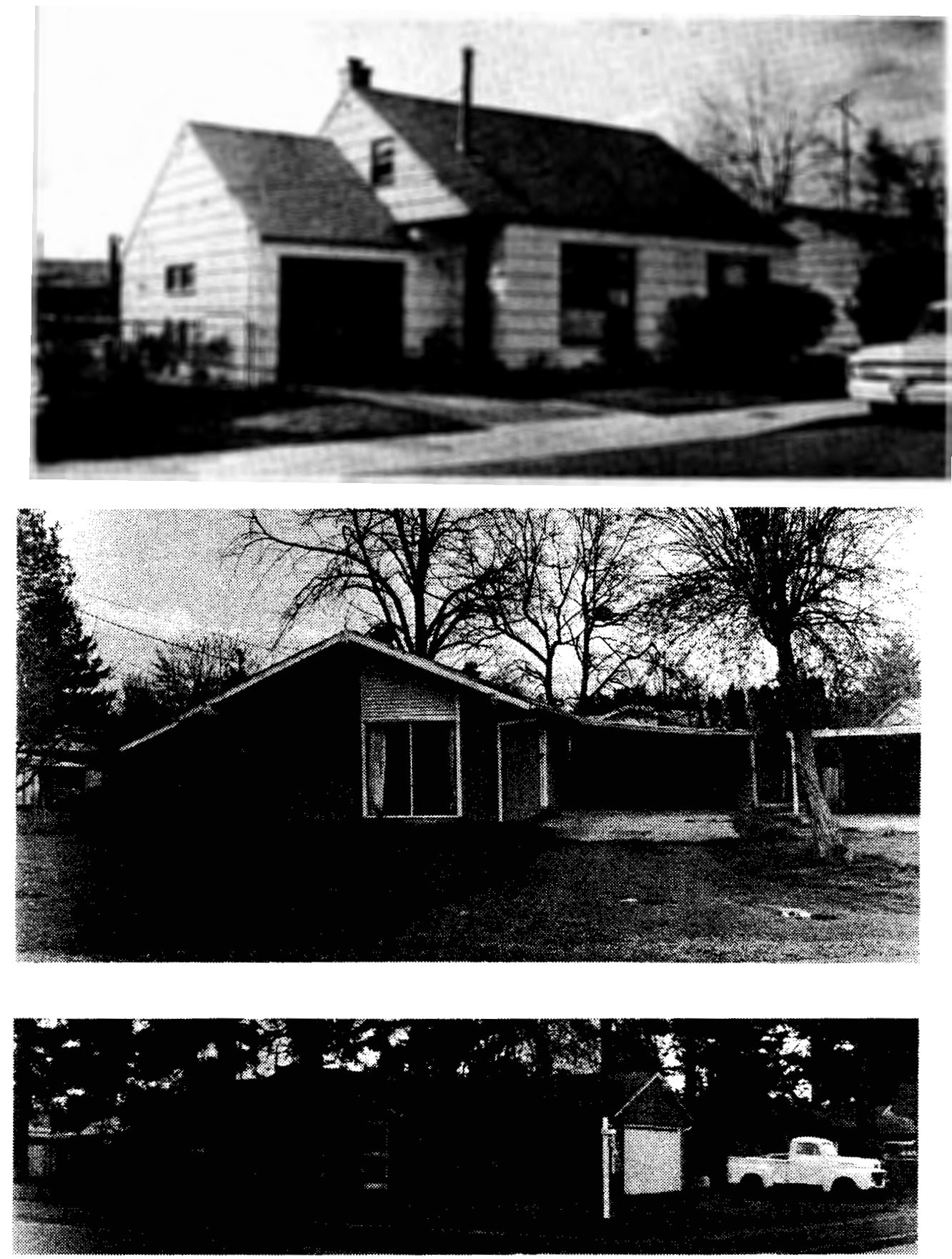

Figure 86. Selected postwar builder's house examples in Portland: 4555 SE 97th Ave., Journal "Home of the Week," 1954. 1930 NE 113th Ave., Gardner \& Romme11 architects, 1952 Home Show "Thrift Group," identical to BH\&G "Five Star" homes model \#1910, Oct.. 1979, pp. 37-41. And, "Whispering Firs" subdivision, NE 113th \& Multnomah, 1952 Home Show. 

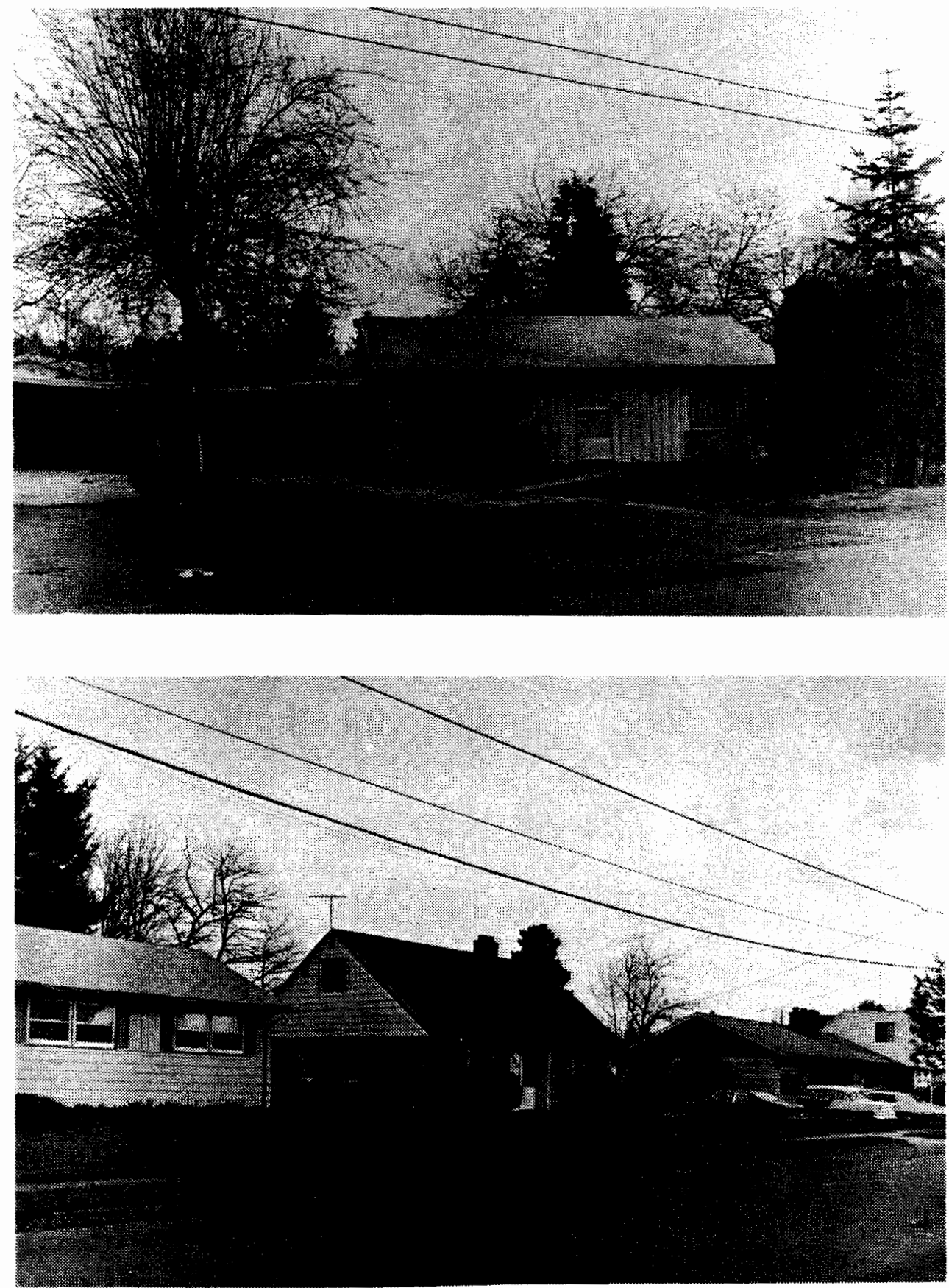

Figure 87. Selected builder's house examples in Portland: Gardner \& Rommel1 designed 1952 Home Show "Thrift Group" model, $1916 \mathrm{NE}$ 113th Ave. And, NE ll4th \& G1isan streets, 1951 Home Show models. 
similar neighborhoods; the demographics of the neighborhood control the care of the houses and not the qualities of the houses determining the demographics. A larger house is more likely to house a stable family than is the smaller one which in just a year or two becomes too small for a growing family. A smaller house in any neighborhood commands a lower rent and may fall subject to being rented or sold to a very low income family which may also be too large for the house and unable to maintain it.

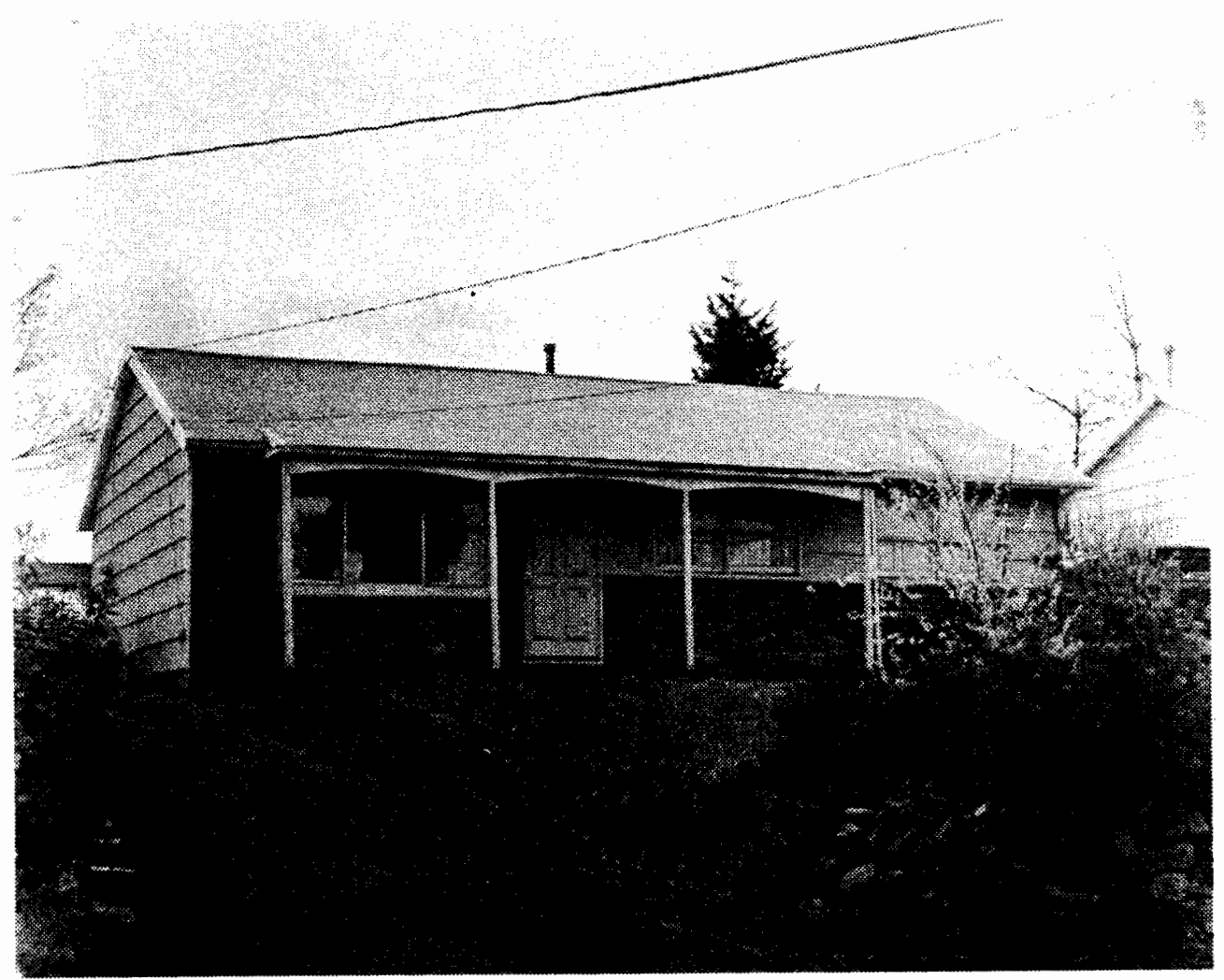

Figure 88. An FHA minimum size, 900 square foot three bedroom house, with bath, kitchen-dining area, utility room, and living room. Hallberg Homes, $8716 \mathrm{NE}$ Halsey Street, Portland. An Oregon Journal "Home of the Week," 1954. 
The experience of living in one of the smallest houses which meets FHA standards is a sobering one if you have an average size family. The construction can be the best there is; but in a 900 square foot size three bedroom house there simply is nowhere to have any adult or children's project which will not be in someone's way at some time; and it is literally impossible for anyone to find solitude when others are in the same house as the apartment size spaces are just

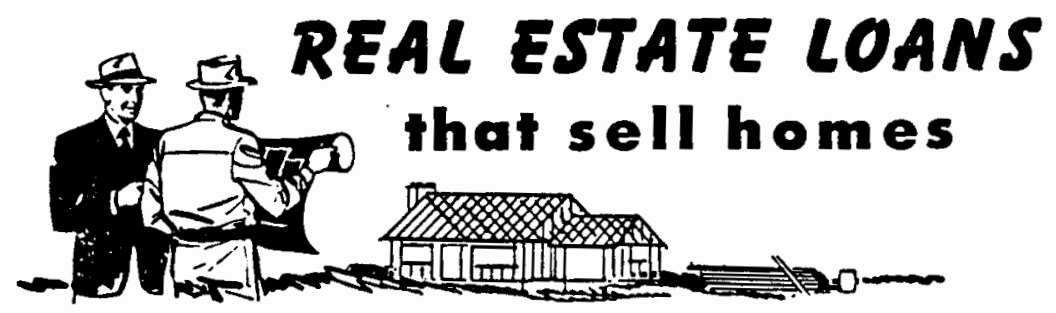

Whether buying, building or refinancing, let our Real Estate Loan Department explain the complete loan services available through this bank.

- Attractive Interest Rates

- No Prepayment Penalties

- Conventional - F.H.A. - G.J.

CONSTRUCTION LOANS TO BUILDERS AND OWNERS

The UNITED STATES HATIOHAL BANK

Member Federal Deposit Insurance Corporation

AN OREGON BANK SERVING OREGON

Figure 89. Advertisement for home loans, 1951. Portland Home Builder.

too close. And, such a small house is in no way smaller than many built in the Depression and before it; it is just that those earlier houses were not expected to accommodate a 
growing family of four or more with all of the postwar household furnishings and gadgets and multiple family activities enabled by a more prosperous economy.

If the dream of the American home was not realized, it may have been because there were flaws in the dream more than in the houses built in its fulfillment. The European model of ideal housing and its modern architecture adaptation for Americans was certainly within the capabilities of the housing industry to achieve. But, in a sense, our very prosperity after World War-II made it impossible to agree on any truly economical universal ideal house type; the buyers were able to select from a variety of styles and types and generally preferred the somewhat traditional models; our prosperity and mobility permitted us to move on to a larger house and leave the small one for others to buy or rent.

If there is a lesson from the experience of attempting to build a private home for everyone, it is that John Keats' questioning in 1956 of the propriety of attempting to offer everyone their own small cottage had some merit. The attendant suburban economic and social burdens from the resulting urban sprawl and the financial strains on a low income family due to home ownership were too heavy. Local governments built the schools, roads, and water systems, and the federal government built the freeways connecting the suburbs to the cities. The home building success of the FHA program was due in large part to the giving of a huge government 

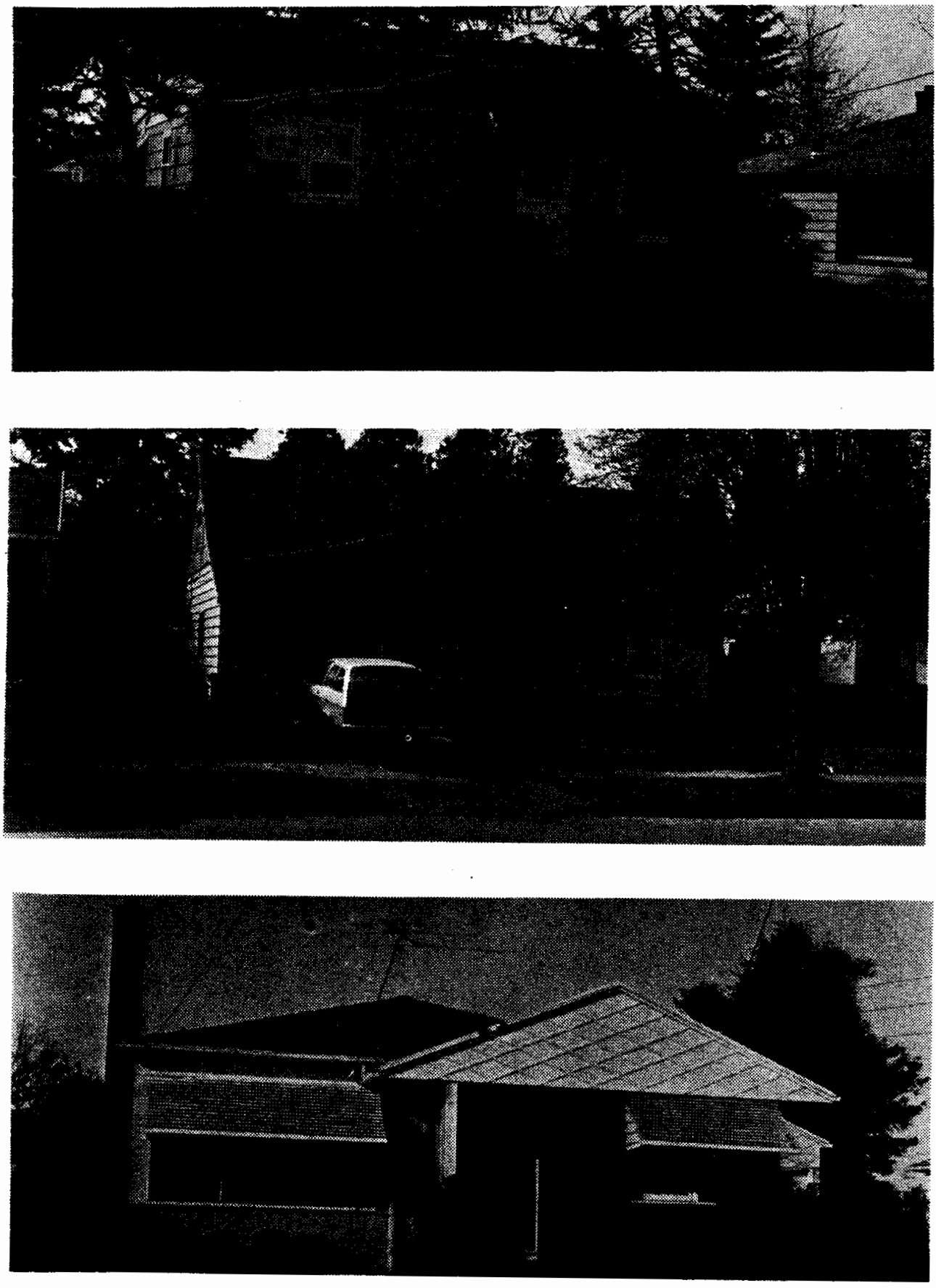

Figure 90. A montage of 1951 model homes, National Home Week examples: 5305 NE 4lst Ave., 9521 N. Portsmouth; and 2833 N. Emerson Street. 

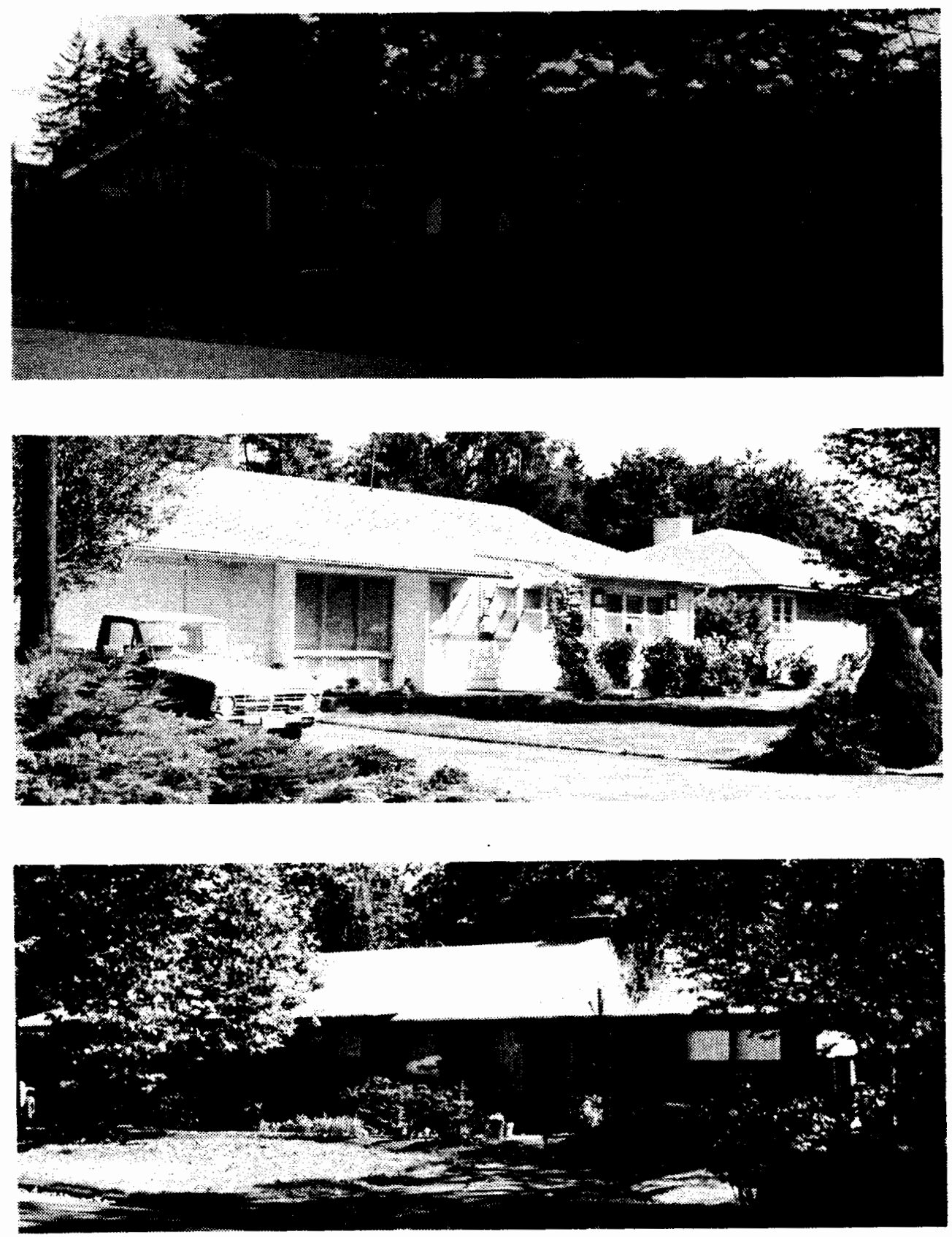

Figure 91. 1954 model homes. Portland Home Builders Association Parade of Homes and Oregon Journal's "Home-of-the-Week:" "Fairway Terrace," NE 131 st and G1isan, Cedar Hills' Ridgewood-SW Douglas St., and 11941 SW Longridge, Cedar Hills. 
subsidy to the home building industry and to the buyers in the form of lowered interest rates and their tax deductibility. Despite all this building, the housing need was never met.

Now, thirty years later, the imperative of the private home ownership goal is less certain; the economic circumstances are different, and many fewer new families want the responsibility of owning a single family detached home although they may expect to own one at a later date. The condominium apartment has generally replaced the small starter house of the late 1940s. Recently, the investment value of a home has lagged behind that of other investments. Home shows now feature the luxury homes in the $\$ 200,000$. price range and nothing that is affordable within the price limits of either FHA or VA insured financing. We now have a very different dream.

\section{THE HOME BUILDING INDUSTRY'S MARK}

The home building industry which was changed by the postwar homes demand and by the programs for making home buying possible for anyone, is now changed again. The old merchant builders are now mostly gone with just a few remaining in commercial property development and not in small single homes. 143 Prefabrication continues to be an

143 Cadillac-Fairview, a leader in the merchant builder area, is now primarily a commercial builder-developer, one of the early contenders for downtown Portland's Morrison 


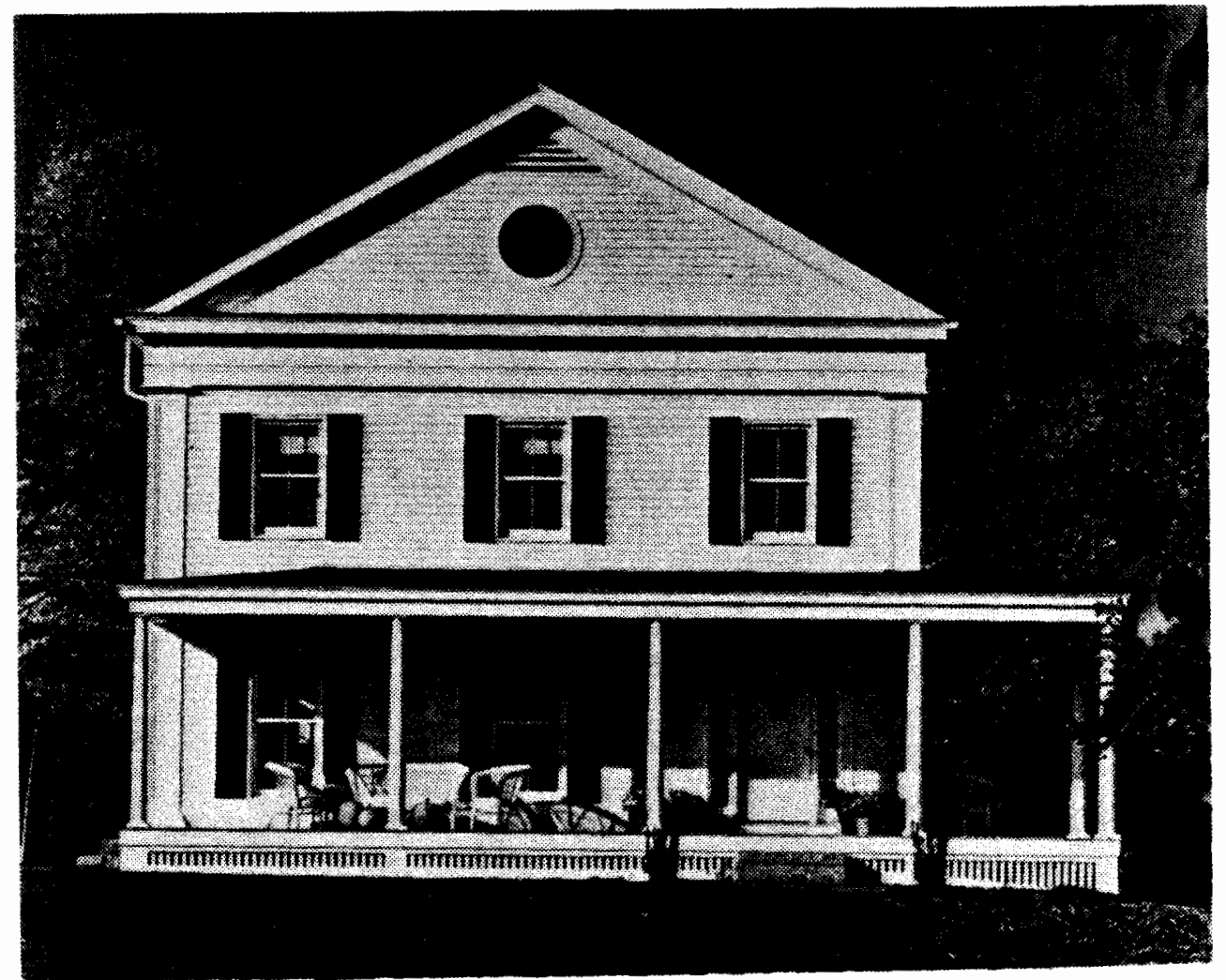

Figure 92. The Souweine Residence, Amherst, Massachusetts, 1985. A symbol of a returning to romanticism and the putting-on of unfamiliar garments. The House house is only a little more restrained and architecturally correct than the current spring 1987 parade of homes models.144

occasional experiment but is now primarily associated with the manufactured homes industry, the old trailer houses. The building of Tanasbourne, west of Beaverton on some of the richest Washington County farmland, was the last loca 1 application of large scale prefabrication of homes for a

Street project. Rising interest rates for mortgages in the late 1970 s and 1980 s ended the home building boom. Eichler, The Merchant Builders, p. 266 and Chapter 14. Co., 1985). 
major subdivision tract. Prefabricated homes are being built in Portland for shipment to military installations in the Arctic as an alternative to the transportation and quartering of workers necessary to build equivalent homes on the site. Otherwise, the industry is still producing the same products and house components in the same ways which were available in the immediate postwar period; there are no complete prefabricated kitchens or bathrooms; and except for a resurrection of some types of pre-cut houses and Lincoln Log type building systems, we have no significant home prefabrication. Almost all new houses which are not derivatives of the mobile home industry are "stick-built" in the same manner as the 1938 and postwar FHA models.

The cost of labor to build a house increased many times over the rates paid during the war years and in 1945. The conversion to power tool cutting and assembly methods had eliminated almost all hand tool work in home building except for certain nailing operations. And, the small home building crafts reverted to being "cottage industries" with the builder subcontracting almost all operations to independent tradesmen who were not union members, often self employed, and did their work on a piece or unit basis. The difference from the conditions of the 1930 s was that the new independent tradesmen had no crafts tradition as it had been established and were often incapable of doing any work requiring traditional skills. The skills were there to 
build plain rectangular boxes which were sound but architecturally undifferentiated unless by differences in paint colors on the surfaces. The application of applied wall paneling or the hanging of decorated kitchen cabinets was sometimes the only relieving change in the otherwise uniformly finished ceiling and walls and the blank carpeted floor. The outsides became similarly stark and wholly dependent on the sculptural qualities of mass, planes, and openings to give variety to the appearance. Owner's site improvements, landscaping, served to replace the differentiation which once had been given by the traditional styles.
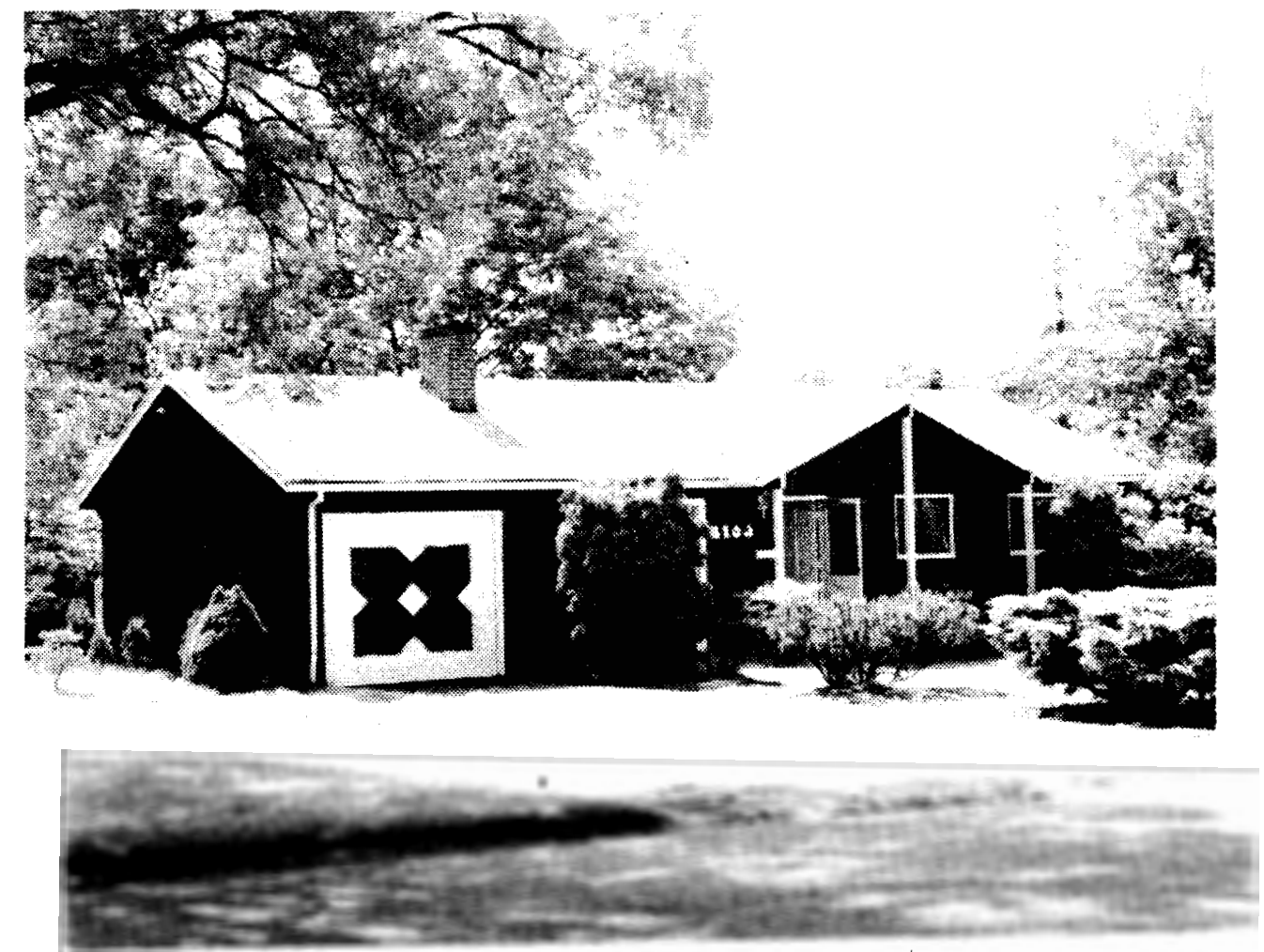

Figure 93. A typical postwar builder's house with a rectangular plan, straight modern lines, but with an attempt at "carpenter's" ornamentation on the garage door. 1954 Parade of Homes. 2183 SW Lynridge Street, Cedar Hills, Beaverton. 
Modern architecture became almost universally adopted for the basic house design only in part because of its acceptance as a popular style. The modern also, was consistent with saving labor and the elimination of ornamental trim frills and their expense. The International Modern Style cannon, "Less is more," was interpreted so that if less ornament meant more savings and the public would accept it, then off came the moldings. Molding free International Modern Style houses also meant that traditional styles were designed with less attention to correct details, mostly the Modern Colonial Style version which became basically a modern house with a Colonial Revival conceit at the entrance. When architects were given commissions to design models for a builder, those architects in postwar America were likely to have been trained in reformed architecture schools which had become almost totally International Style oriented and taught none of the traditional style disciplines; al1 ornament was not functional, hence bad. It became dictum that all traditional style building characteristics were merely ornament and could be put on or better left off as wanted. A stock millwork door frame with a pediment could be attached to the entrance of a basically modern cottage and, 10 , it becomes a Colonial Revival Style cottage.

More important were the materials and building systems technology which was first proven in mass housing during the 
war and became standard building practice afterward. Exterior plywood panels for sheathing under other exterior roof and wall materials, for subflooring, and as combination

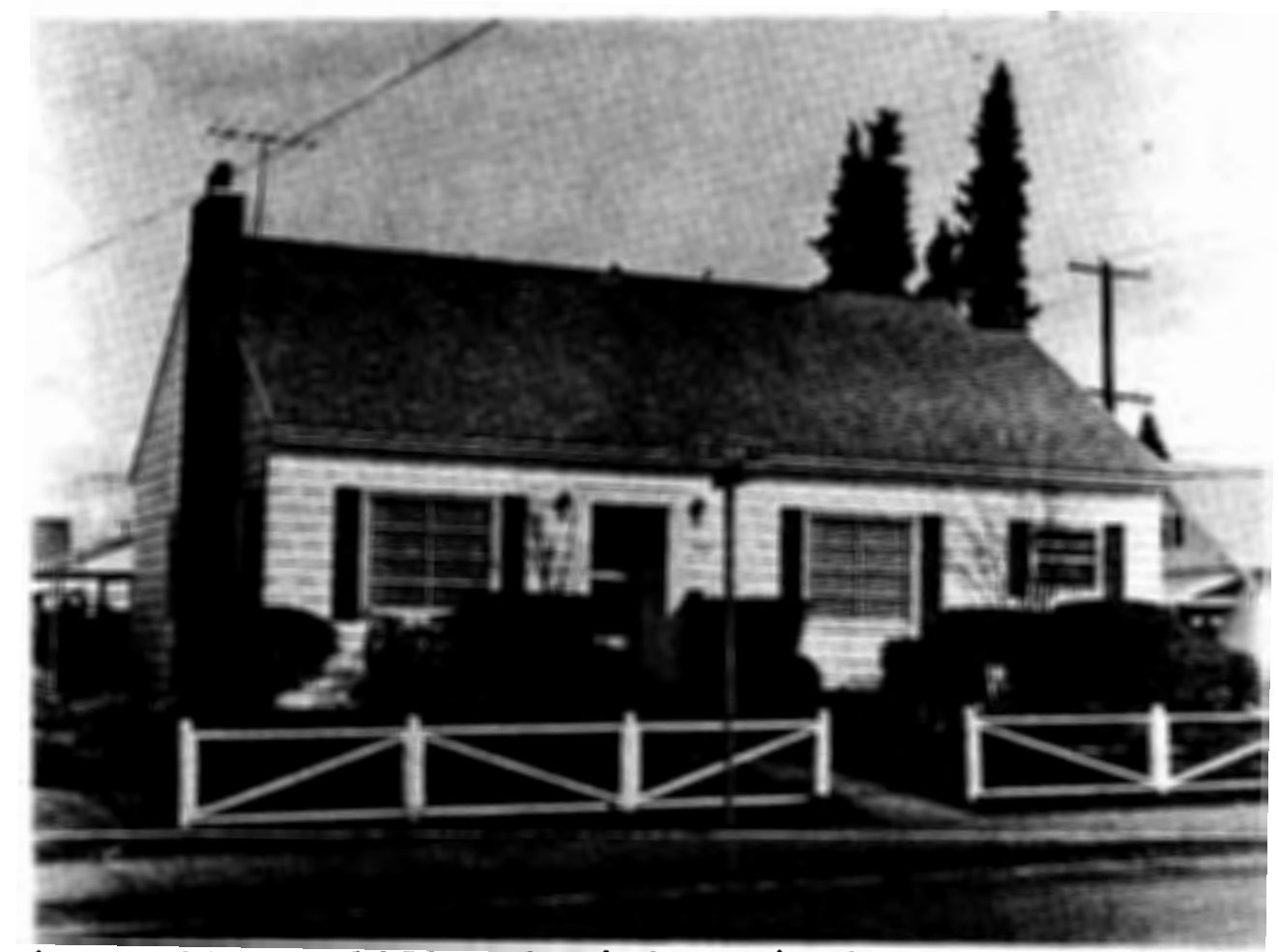

Figure 94. A 1951 Colonial Revival Style builders house. A plain box with entrance trimmings. SE 54th and Stark Streets, Portland.

sheathing and siding panels was introduced in 1937 and most prominently first used by John Yeon in his builders' house designs. Later, Yeon realized the ultimate elegance of the plywood wall panel system in his Portland Visitors Information Center Building of 1949, a spare but not Spartan design. The four by eight foot plywood panel and its corresponding gypsum wallboard panel for the inside was the modular standard for most of the wartime housing units.

The easily assembled and quickly erected panels of 
stud framed walls when combined with standard manufactured roof truss framing meant that a small house could be erected fully rough framed and enclosed within a matter of several days once the foundation was in place. Within this sheltering envelope the insulation, electric wiring, plumbing, and heating systems could be built simultaneously by crews working on several identical houses at once moving from one to the other as each phase or task was completed, performing a succession of repetitive operations over and over. Doors and windows with their trim came to the site as pre-finished and assembled units only needing to be set in the rough opening, squared, and the pre-cut casing tacked in place. A simple house could be finished in a week, and demonstration houses were often completed in a single day including landscaping and furnishings. The allotted time for one carpenter to install a complete pre-hung entrance door is 30 minutes. 145

THEY AREN' $T$ BUILDING THEM LIKE THEY USED TO

The postwar FHA insured builders' house was not built "like they used to." Its differences are apparent and indicate both that there were changes in building methods and materials and also in the design of the postwar dream home compared with the prewar counterpart. The differences

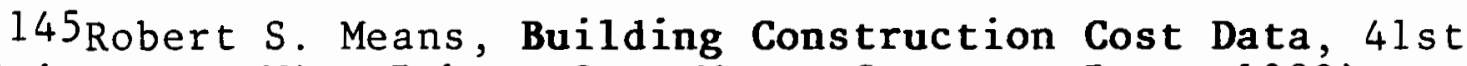
ed. (Kingston, MA: Robert Snow Means Company, Inc., 1983). 
are in the adoption of Modern Style elements where they contribute to the simplification and therefore lower cost of the postwar houses. A few immediate postwar houses are built as the continuation of the prewar one and one and onehalf story traditional house models, but these are quickly replaced by single story houses with lower roof slopes and no habitable attic area. Basements are eliminated since all houses are built with either concrete slab-on-grade

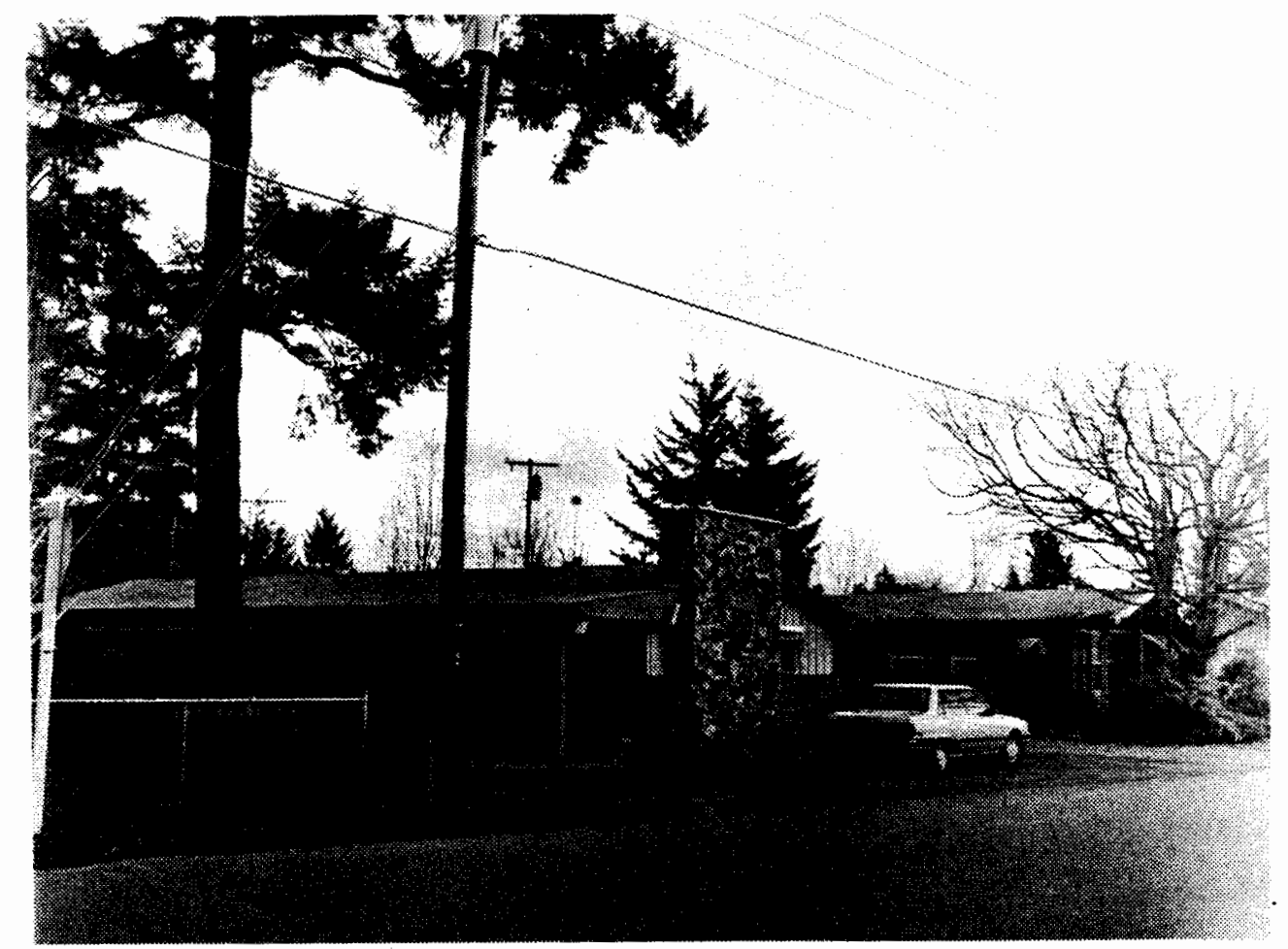

Figure 95. A modern picture window house. 1952 Home Show model, Saddlewood Development, SE 143 and Mill streets.

foundations or with perimeter foundation walls and wood floors over a crawl space. The "picture window" emerges as a pejorative characteristic. Window styles are experimented with, from fixed sash and ventilation louver panels like 
those introduced by John Yeon in 1938, to unframed sliding glass panes in a site-built finish frame, used as a very modern experiment and soon discontinued. Most notable about the exteriors of the postwar houses compared to the prewar ones was the minimal use of any finish trim except at corners and other locations where it was necessary to cover a crack; most windows and door frames were self trimming or had only plain narrow rectangular casing boards, facia boards used common lumber in place of finish grades, and undersides of any eaves began to be left unfinished, exposing the common lumber and plywood sheathing surfaces with a coat of paint or stain.

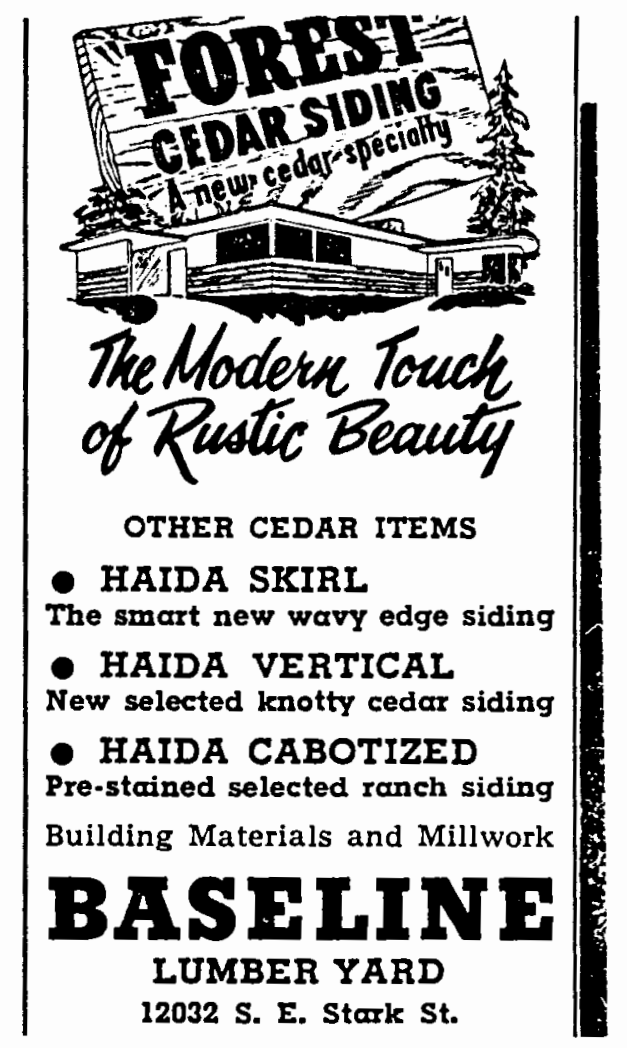

Figure 96. Special pattern siding was featured on the early postwar houses. 
There was a five year period after World War-II when there were several special ornamental cedar siding patterns sold, which at that time were standard Western Wood Products Association patterns. These are modern appearing 8 to 12 inch wide horizontal (mostly) siding boards with shiplap or tongue and groove edges and various milled longitudinal grooves which emphasize the horizontal motif. The milled grooves are sometimes "Vee" and sometimes rounded. These special pattern sidings were sold along with simulated 1 og cabin siding patterns, with only the log cabin still available. Mill pre-painted or pre-stained sidings also eliminated that field step. Some houses had pre-finished hardboard siding which resembled the customary cedar and pine lap siding boards.

The use of wood and shingle siding over concealed sheathing was diminishing beginning in the early 1950 s when the combination plywood siding-sheathing panels became available. The use of T-11l pattern plywood siding became almost universal for low-cost house building because of its economy. The factory milled grooves in the plywood panel face gave it an appearance similar to some siding board patterns and controlled surface veneer checking. Properly installed and finished, the plywood panels were as strong as the older system of sheathing and siding, were long lasting, and much more economical. As with any very popular material, overuse and misuse resulted in a reaction against the 
product as it became equated with "cheap."

\section{A NEW BALANCE BETWEEN OLD AND NEW HOUSES}

The postwar builders houses had to meet a rising standard of minimum FHA requirements. Before the war, the typical house's quality was set by customary practices as determined by the architect or by an established builder. This self policing worked very well for a limited building effort where the volume was low and designers, builders, and workmen all came from the same experience base with a disciplined pallet of architectural styles, customary building methods, and familiar materials. Everyone understood the rules.

Better building standards had to be developed for the postwar conditions of higher building volume, new builders and workers, and new methods and materials. The FHA Minimum Property Requirements evolved from being basic guidelines into a residential building code. The results may have sometimes not looked as good as before, but the soundness and value of the houses built was protected and even improved in some areas. Concrete making and placing requirements were uniformly better. Plywood sheathing and siding produced stronger building frames than were generally built before. Standards for anchorage and wind uplift resistance were added. More homes were insulated for 


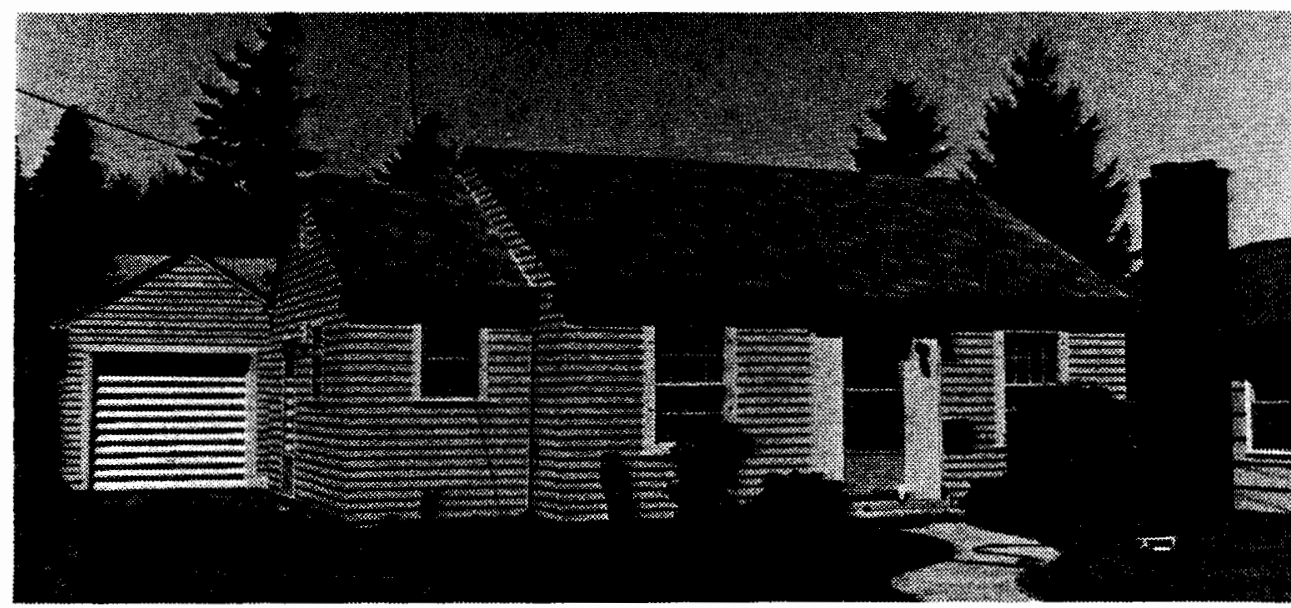

Figure 97. A 1938 FHA house in Portland. Clarence Miller residence, 4211 NE 63rd Ave.

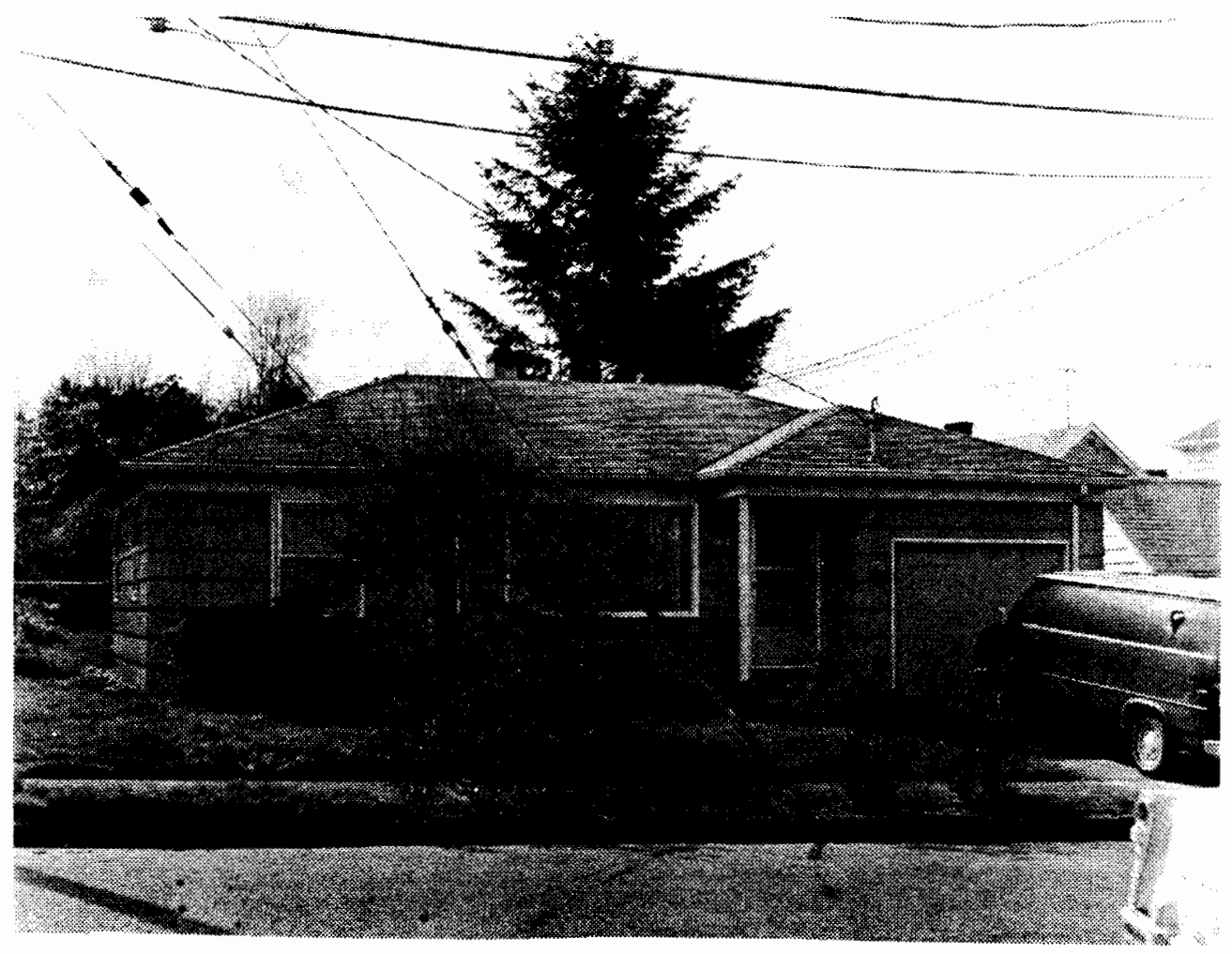

Figure 98. A 1954 FHA house in Portland. A Journa1 "Home of the Week," 5204 SE Washington Street. 
heating and cooling economy. Fire protection standards were incorporated. Minimum room dimensions were adopted.

Reference standard specifications containing the results of basic building research were made a part of the revised MPRs. And many other previously optional requirements were codified. Unless there was a breakdown in enforcement, the new home owner was assured of getting basic good value for his money no matter who the builder was or in what part of the country. There might be lasting deficiencies in the planning of low-cost homes subdivisions but not in the construction of the houses themselves.

The appearance differences do count in the lasting condition of the houses and their value. The prewar houses look much more substantial and are in generally better condition than the ones built ten years later. The appearance of a prewar builders' house is that of a complete finished house in a recognized building style. The prewar house looks well built and is very likely to be well maintained. The postwar builders' house is a simplified or stripped version of its prewar cousin if one of the traditional style models. The postwar traditional style house derivation will look flatter and be less detailed than the Depression one. The postwar modern house will look more Spartan than it would have appeared if built in the 1930s. The postwar loss of details is true even when the house has been decorated with two or more different patterns of siding 
or with combinations of different facade materials, wood, stone, or brick.

The reason for the pejorative differences between prewar and postwar houses is that the earlier homes' traditional style base allowed them to undergo the changes of aging and even of some neglect while retaining some grace, to have a special identity which is fundamental to them. The newer houses, because they had lost some of the discipline of the traditional styles, have less identity and do not age as well. A neglected 1938 Colonial Revival Style house nevertheless looks like a solid older house which needs attention. A neglected 1948 Modern Ranch Style house looks shabby and undistinguished. Both houses can be the same size, located in similar neighborhoods, and be well built---with the newer house possibly being less expensive to maintain and with lower heating costs, unless both have been weatherized recently. But, the 1938 house will look better and will most likely have retained its value better than one of the later ones---neighborhood values being roughly equal.

There was a large body of early postwar homes which were built under the continuing strong influence of traditional prewar building practices and which represent a better value than the later models because of the greater attention to good building details and finishes. 


\section{LOST ARTS ARE NOT LOST}

It is often said now that fine building arts and workmanship are lost crafts, that there are no carpenters, plasterers, and painters now to build like they used to do. In fact, fine workmanship and the making of special finishes are not lost arts, it is just that there are very few demands for that kind of work and 1 ittle effort is spent on locating the craftsmen able to do it. Because the labor cost of fine workmanship and older finishing methods is expensive, most modern homes cannot afford it. The costs of the traditional workmanship do not fit the standard schedules for most residential building and will not be found unless there is a special effort made.

The postwar builders' houses are a distinct type of low-cost homes because of four characteristics which identify them: a conformity of plan and size based on meeting the minimum requirements of the FHA standards; adoption of a small home style derived from the popular acceptance of those elements of International Modern architecture which lowered costs but without understanding the design principles of the modern; the loss of the historical derivation of traditional moldings and architectural ornament from functional building elements and their reduction to a few mere decorations; and the change from labor intensive building practices and finishes to those made available by prefabrication and suitable for power tool 
installation and production methods. The changes came because of the government support of mass home building and its regulations, because of labor and economics changes during and after the World War-II, because new materials and building methods were first tried on large scale during the war and after when home building became a major industry, and because the stripped down qualities of International Modern Style met the need to reduce labor and material costs and were adaptable to using modular building panels in place of customary exterior sidings and interior plaster work.

Each generation has had its peculiar house styles which were related to the culture of that period. The American Victorian styles reflected the goals of early Industrial Revolution America after the Civil War. The Bungalow Era from 1900 to World War-I was an identifiable departure from the Victorian styles. The 1920s have their characteristic revival styles expressing hopes for material success. The Depression Era houses are modest yet substantial dream-home cottages. The small houses after World WarII are domestic architecture produced and marketed as a commodity, embodying the changes wrought by the one and onehalf decades of the Depression and World War-II. The houses of 1934 to 1941 and 1945 to 1954 speak for themselves. 
LIST OF WORKS CONSULTED

BOOKS

Aaron, Henry J., Shelter and Subsidies (Washington: The Brookings Institute, 1972).

Akers, 0. M., The Telegram Plan Book (Portland: Telegram Publishing Co., 1924).

Allen, Edith Louise, American Housing (Peoria: Manual Arts Press, 1930).

American Builder, ed., American Builder Year Book: Modern Homes, Their Design and Construction (Chicago: American Builder Publ. Co., 1930).

American Institute of Architects, James Bailey, ed., New Towns in America (N.Y: John Wiley \& Sons, 1970).

The Architectural Forum, The 1936 Book of Small Homes (N.Y: Simon and Schuster, Inc., 1936).

Balderston, Linda Ray, Housewifery (Philadelphia: J. B. Lippincott, Co. 1924).

Beecher, Catharine E. and Harriet Beecher Stowe, The American Woman's Home, reprint of 1869 ed. (Hartford: Stowe-Day Foundation, 1975).

Beyer, Glen H., Housing: A Factual Analysis (N.Y: The Macmillan Company, 1958).

Bragdon, Claud, FAIA, Architecture and Democracy (N.Y: Alfred A. Knopf, 1918).

Brogan, Dennis W., The Era of Franklin D. Roosevelt (New Haven: Yale University Press, 1950).

Bush, Donald J., The Streamlined Decade (N.Y: George Braziller, 1975).

Calvert, Frank, ed., Homes and Gardens of the Pacific Coast, Vo1. 1, Seattle, orig. 1913 (Seattle: Christopher Laughlin, Historic Preservation Committee of Allied Arts of Seattle, 1974). 
BOOKS-CONTINUED

Clark, Ann Brewster, Wade Hampton Pipes (Portland: Binford \& Mort Publishing, 1986).

Coffin, Lewis A., American Country Houses of Today (N.Y: Architectural Book Publishing Company, Inc., 1935).

Congressional Quarterly Service, ed., Housing a Nation (Washington: Congressional Quarterly Service, 1966).

The Congressional Record, Vol. 78, Part II, 73rd Congress, 2nd session 14 June 1934.

Cour, Robert M., The Plywood Age (Portland: DFPA-Binfords and Mort, 1955).

Cummings, Betty. H., Housing in War and Peace (Vancouver: Housing Authority of the City of Vancouver, Washington, 1972 ).

Dean, John P., and Simon Breines, The Book of Houses (N.Y: Crown Publishers, 1946).

Department of Labor, Report on the United States Housing Corporation, Vol. II, Houses, Site Planning, Utilities (Washington: Government Printing Office, 1919).

DeLong, Mr. and Mrs. W. W., Seattle Home Builder and Home Reeper (Seattle: Commercial Publishing Co., 1915).

Eichler, Ned, The Merchant Builders (Cambridge: MIT Press, 1982).

Erickson, Emanuel E., Planning Your Home (Peoria: The Manual Arts Press, 1938).

Forest Products Laboratory, Age of Wood: Progress Through Wood Research, 75 th Anniversary booklet (Madison: FPL, 1985 ).

--- Wood as an Engineering Materia1, Agriculture Handbook No. 72 (Washington: GPO, 1972).

Fowler, O. S., A Home for Al1, or The Gravel Wall and Octagon Mode of Building (N.Y: Fowler \& Wells, 1854).

Gilbert, Herbert, The Dream of the Factory Made House (Baltimore: The Johns Hopkins Press, 1978). 
Group, Harold E., House-of-the-Month Book of Small Houses (N.Y: Garden City Publishing Company, 1946).

Harrington, M. R., How to Build a California Adobe (Los Angeles: Ward Richie Press and Southwest Museum, 1948).

Hearn, Charles R., The American Dream in the Great Depression (Westport, Conn: Greenwood Press, 1977).

Hering, Oswald C., Concrete and Stucco Houses (N.Y: Robert M. McBride \& Co., 1922).

Hidy, Ralph W., Frank Ernest Hill, and Allan Nevins, Timber and Men: The Weyerhaeuser Story (N.Y: The Macmilian Co., 1963 ).

Howard, Ebenezer, Garden Cities of To-Morrow, ed. F. J. Osborn (Cambridge: The MIT Press, 1965).

International Council on Monuments and Sites, Eisen Architecktur (Mainz: ICOMOS Deutches Nationalkomitee, 1979).

Jacobs, Jane, The Death and Life of Great American Cities (N.Y: Vintage Books, 1961).

Kaufmann, Edgar, An American Architecture (N.Y: Bramhal1 House, 1960).

Keats, John, The Crack in the Picture Window (Boston: Houghton Mifflin, Co., 1956).

Kidder, Tracy, House (Boston: Houghton Mifflin Co., 1985).

Lasch, Robert, Breaking the Building Blocade (Chicago: University of I1linois Press, 1946).

Lescarboura, Austin C., Home Owner's Handbook (N.Y: Scientific American Publishing Co., 1924).

Loring, Charles G., ed., The House Beautiful Annual, 1925 (Boston: The Atlantic Monthly Co., 1924).

McClelland, John A., Jr., R. A. Long's Planned City: The Story of Longview (Longview: Longview Publishing Company, 1976). 
BOOKS-CONTINUED

Marx, Arthur, The Nine Lives of Mickey Rooney (N.Y: Stein \& Day, 1984).

Mason, Joseph, B., History of Housing in the U.S., 19301980 (Houston: Gulf Publishing Co., 1982).

Means, Robert S., Building Construction Cost Data (Kingston, MA: R. S. Means Co., Inc., 1983).

Murtaugh, Gilbert, Small Houses (N.Y: Doubleday, Page \& Co., 1924).

National Park Service, Historic American Buildings Survey (Washington: GPO, 1941).

Official Guide Book: New York World's Fair-1939 (N.Y: Exposition Publications, Inc., 1939).

Peterson, Charles E., The Moore House (Washington: Nationa 1 Parks and Conservation Assoc., 1981).

Placzek, Adolf K., ed., The Origins of Cast Iron Architecture in America (N.Y: Da Capo Press, 1970).

Pratt, Richard, A Treasury of Early American Homes (N.Y: McGraw-Hi11 Book Company, Inc., 1946-1949).

Radford, William A., Architectural Details for Every Type of Building (Chicago: Radford Architectural Co., 1925).

Radford, ig09).

Ramsey, Charles George, and Harold Reeve Sleeper, Architectural Graphics Standards, 5 th Ed. (N.Y: John Wiley \& Sons, Inc., 1966).

Rogers, Tyler Stewart, Plan Your House to Suit Yourself (N.Y: Charles Scribner's Sons, 1938).

Roosevelt, Franklin D., The Public Papers and Addresses of Franklin D. Roosevelt, Vols. 3, 6 (N.Y: MacMillan Co., 1941).

Schlesinger, Arthur M., The Coming of the New Deal (Boston: Houghton Mifflin Co., 1959).

(Boston: Houghton Mifflin Co., 1960). 
Schuyler, Montgomery, American Architecture and Other Writings, ed. Wm. H. Jordy and Ralph Cole (Cambridge: Belknap Press of Harvard U. Press, 1961).

Stevenson, Katherine Cole, and H. Ward Jandle, ed., Houses by Mail (Washington: Preservation Press, 1986).

Sunset Western Ranch Homes (Palo Alto: Lane Publishing Co. $1946)$.

Vaux, Calvert, Villas and Cottages (N.Y: Harper \& Brothers, 1857 ).

Wills, Royal Barry, Houses for Homemakers (N.Y: Franklin Watts, Inc., 1945).

Wollner, Craig E., The City Builders: One Hundred Years of Union Carpentry in Portland, Oregon, 1883-1983 (Portland: Carpenters Union Local \#247, 1984).

Wright, Gwendolyn, Building the Dream: A Social History of Housing in America (N.Y: Pantheon Books, 1981).

MAGAZINES \& ARTICLES

AIA Journal: June 1982 .

American Builder: April 1946; July, November, December 1948 .

Architectura1 Forum: May 1935; April and November 1939.

The Cement Era: June 1906-December 1908 .

Godey's Magazine: July-December, 1871 .

Life: 31 January 1949.

The New Republic: 24 October, 15 November 1933; 31 January, March, and $4 \mathrm{July} 1934$.

Pencil Points: November 1941.

The Portland Home Builder: August-October 1945, 1951.

Progressive Architecture: February 1982. 
The Saturday Evening Post: 2 May 1938.

Wheeler, Bayard 0., "Housing Needs of the Pacific Northwest...," Pacific Northwest Industry, Univ. of Washington, Seattle, August 1947.

\section{REPORTS AND TECHNICAL STUDIES}

Gotlieb, Manuel, Estimates of Residential Building, United States, 1840-1939, Technical Paper 17, National Bureau of Economic Research, New York, 1964.

\section{MANUSCRIPT SOURCES}

Weyerhaeuser Timber Company Archive, Tacoma, Washington

29 Home Designs (St. Paul: Weyerhaeuser Co., 1948).

Correspondence on experimental House for R. C. Reamer, Seattle, Washington.

Information on Tim-Bo-Lock System, Plunkett-Webster Company. T. L. O'Gara Letters.

FHA, Modernization Credit Plan, news release, August 10 1934 .

Weyerhaeuser Modular House, brochure, correspondence, General Timber Service, Inc.

The Library of Congress, Washington, D.C.

Photographs and Maps Collection: Greenbelt, Maryland; Longview, Washington; Taft, California; War Housing Trailers and Mobilhome Corp., San Diego, California; from Farm Security Administration. Westpark and Yesler Terrace, Bremerton and Seattle, Washington; McLoughlin Heights, Vancouver, Washington; Columbia Villa, University Homes, and Vanport, Portland, Oregon; from U.S. Public Housing Administration. 
Longview Daily News Library, Longview, Washington

Longview Homesteads file, manuscripts and photographs.

Longview Public Library, Longview Room Collection, Longview, Washington

Longview Homesteads and History of Longview collected manuscripts and photographs.

National Archives, Washington, D.C.

File No. NC3-31-77-1, Correspondence between state governors and President Franklin D. Roosevelt Covering FHA Legislation, 1934-35.

First Annual Report of the FHA, House Document No. 88, 74 th Congress lst Session (Washington: GPO, 1935).

Second Annual Report of the FHA, 31 December 1935 (Washington: GPO, 1936).

Fifth Annual Report of FHA, December 1938 (Washington: GPO, 1938).

FHA, Eighth Annual Report, December 1941 (Washington: GPO, 1941).

FHA Sample Case Files for Housing, boxes 2, 18 , and 20, "Sample Folders of Typical American Homes (1934-1938):"

A Residence for Mr. and Mrs. C. W. Nash, Wenatche, Wash. Ivan H. Meyer, architect, Seattle.

A. Hallgren Residence, San Francisco, Calif.

Mr. and Mrs. Joe Kolick Residence, West Street, Salinas, Calif.

Six Room Dwelling to be Erected on 16th \& Morega St., San Francisco, Calif. Henry Doelger, builder.

Mr. and Mrs. Stephen McCoy Residence, Lot 34 Terrace Garden \#3, Salinas, Calif. David H. Horn, architect.

Residence for H. A. Werder, 448 Middlefield Road, Redwood City, Calif. 


\section{MANUSCRIPT SOURCES-CONTINUED}

Mac Boyker Residence, 102 Kennebec Ave., Kent, Wash. J. H. DeHart, architect.

Mr. and Mrs. Carl H. Baber Residence, 6221 36th Ave. NE, Seattle, Wash. Howard H. Riley, architect.

R. R. Ramsey Residence, 9700 42nd SW, Seattle, Wash. J. C. Eilers, builder.

$\mathrm{Mr}$. and Mrs. Ernest R. Wilkins Residence, Lot 10 Block 8 Division 4, View Ridge Addition (corner 49th E. and E. 65 th) Seattle, Wash. Lowel1 V. Casey, architect.

Residence for Mr. and Mrs. Harold M. Conway, Windemere, Seattle, Wash. Penrith Road, Lot 17 Block 11 . George Wellington Stoddard, architect.

Residence for Mr. and Mrs. Peter R. Danskow, $2730 \mathrm{NE} 70$ th Avenue, Portland, Ore. Peter R. Danskow, designer.

2001 NE 64th Avenue, Portland, Ore. Johnson, Wallwork, and Dukhart, architects.

Residence for Dr. and Mrs. Carl W. Emmons, E. Knobhill and Fawk Street, Salem, Ore. Frederick H. Eley, architect.

Residence Building, 5131 NE 35 th Place, Portland, Ore. Wallace Landreth, architect.

Residence Building for J. G. Roth, Pierce Street between Shoup and Heyburn, Twin Falls, Idaho. John S. Kines, builder.

J. A. Sandy Residence, 909 NE 10th Street, Boise, Idaho.

Residence, 442 N. Arthur, Pocatello, Idaho.

Residence for Miss Ellen Reierson, 6 th St. near Hayes, Moscow, Idaho. M. W. Melzian, architect.

Residence for Pope \& Cottle, Augusta, Maine. Royal Barry Wills, architect.

Residence for Prof. James H. Waring, Orono, Maine. Edward S. Kent, architect.

Residence for Mr. and Mrs. Clarence Miller, 4211 NE 63rd Avenue, Portland, Ore. 
Residence for Mr. and Mrs. Carlton W. Hornibrook, Pacific Avenue, Klamath Falls, Ore. Howard R. Perrin, architect.

Residence for Joseph Pulawski, Newport Ave., Pawtucket, Rhode Island.

Residence for Walter F. Ulmer, Bangor, Maine. Victor Hodgins, architect.

Three Cottages, Birmingham and Monteva11o, Alabama.

Smal1 Homes Council, University of Illinois, Champaign

A Demonstration of New Techniques for Low-Cost Small Home Construction, Housing Research Paper 29, HHFA (Washington: GPO, 1954).

Design Standards for Construction of Permanent Housing for Federal Personne1, HHFA (Washington: GPO, 1953).

Housing and Home Finance Administration, Technical Bulletin series (Washington: HHFA, 1947-1948).

National Bureau of Standards, Building Materials and Structures Report series (Washington: GPO, 1940).

Successful Farming, 1944.

Transcript of 1947-1948 Lecture Series, The Home Institute, NW National Bank, Minneapolis, Minn.

Oregon Historical Society, Portland, Oregon

Van Evera Bailey, architect, drawings and office files.

Home Builders Association of Metropolitan Portland, Portland, Oregon

Home Show promotional files and correspondence.

Portland Homebuilder, 1945-1954.

Clippings scrapbook on Home Shows and Home of the Week programs. 
The Aladdin Company, Aladdin Homes "Built in a Day", catalog (Bay City, Mich: The Aladdin Company, 1920).

Elwood Wiles, \& Son, brochure for Millmade Sectional Homes, c. 1920 .

The Home Designer, February 1922, promotional journal, Oakland, California.

Housing Authority of Bremerton, booklet of tenant information on Westpark, Bremerton, Washington.

The National Trust for Historic Preservation, Pope-Leighey House, information brochure and measured drawings reproductions packet.

Official Pictures of A Century of Progress Exposition (Chicago: Reuben H. Donnelly Corp., 1933).

Redimade Building Company, brochure for "Sectional Houses," 10 June 1920.

Sma11 Homes Yearbook, catalog, National Home Builders, Inc., 1941 .

Souvenir Views, Chicago World's Fair (Chicago: Curt Teich \& Co., 1934).

West Coast Lumbermen's Association, Four Low Cost Homes of Architectural Merit, 1933 Models, brochure (Seattle: WCLA, 1933).

Whitehead, Russell F., ed., The White Pine Series of Architectural Monographs, quarterly 1915-1924 (St. Paul: White Pine Bureau).

POPULAR SONGS

Conley, Larry and Willard Robinson, A Cottage for Sale (N.Y: DeSilva, Brown, Henderson, Inc., 1930).

Reynolds, Malvina, "Little Boxes" (1962), The Malvina Reynolds Songbook (Berkeley: Schroder Music Company, 1974). 
The Oregon Journa1, 10 August 1933, 6 January 1934, 17 October 1942, 3 August 1945, 15 December 1946, 31 August 1947,9 May 1948.

The Oregonian, 3 April 1938, 2 March 1941, 27 August 1944, 6 January 1946, 14 July 1946, 14 August 1949, 1 September 1949, 1 November 1949, 14 December 1949, 29 August 1951, 3 September 1951,18 August 1985.

\section{UNPUBLISHED SOURCES}

Rosenbaum, Charles S., "Housing and Housing Reform in Portland, Oregon, 1900-1934: An Examination of the Response to Urbanization During the Progressive Era." Thesis. Reed College, 1972.

Potter, Elisabeth Walton and Alfred M. Staehli, A History of HABS and HAER in Oregon, 1933-1983.

\section{INTERVIEWS}

Dodds, Linda, and Alfred M. Staehli, "Interview with Architect Richard Wilhelm Sundeleaf," oral history transcription 1982, Oregon Historical Society, Portland, Oregon.

Staehli, Alfred M., notes on history of Oregon Mutual Savings Bank, 30 May 1985, Portland, Oregon. , notes on interview with John Yeon, 25 September 